\title{
Al doende leert men : enkele studies naar aspecten van betrouwbaarheid en validiteit over de toetsing van vaardigheden
}

Citation for published version (APA):

van Luijk, S. J. (1994). Al doende leert men : enkele studies naar aspecten van betrouwbaarheid en validiteit over de toetsing van vaardigheden. [Doctoral Thesis, Maastricht University]. Datawyse / Universitaire Pers Maastricht. https://doi.org/10.26481/dis.19941021sl

Document status and date:

Published: 01/01/1994

DOI:

10.26481/dis.19941021sl

Document Version:

Publisher's PDF, also known as Version of record

Please check the document version of this publication:

- A submitted manuscript is the version of the article upon submission and before peer-review. There can be important differences between the submitted version and the official published version of record.

People interested in the research are advised to contact the author for the final version of the publication, or visit the DOI to the publisher's website.

- The final author version and the galley proof are versions of the publication after peer review.

- The final published version features the final layout of the paper including the volume, issue and page numbers.

Link to publication

\footnotetext{
General rights rights.

- You may freely distribute the URL identifying the publication in the public portal. please follow below link for the End User Agreement:

www.umlib.nl/taverne-license

Take down policy

If you believe that this document breaches copyright please contact us at:

repository@maastrichtuniversity.nl

providing details and we will investigate your claim.
}

Copyright and moral rights for the publications made accessible in the public portal are retained by the authors and/or other copyright owners and it is a condition of accessing publications that users recognise and abide by the legal requirements associated with these

- Users may download and print one copy of any publication from the public portal for the purpose of private study or research.

- You may not further distribute the material or use it for any profit-making activity or commercial gain

If the publication is distributed under the terms of Article $25 \mathrm{fa}$ of the Dutch Copyright Act, indicated by the "Taverne" license above, 


\section{Al doende leert men}

Enkele studies naar aspecten van betrouwbaarheid en validiteit over de toetsing van vaardigheden 
Omslagnntwerp: Joop Noordkamp

Produktie: Datawyse / Universitaire Pers Maastricht

OScheltus Jan van Luijk, Maastricht, 1994

\section{CIP-gegevens Koninklijke Bibliotheek, Den Haag}

Luijk, Scheltus Jan van

Al doende leert men: enkele studies naar aspecten van

betrouwbaarheid en validiteit over de toetsing van

vaardigheden/Scheltus Jan van Luijk. - Maastricht:

Universitaire Pers Maastricht.

Proefschrift Maastricht, Met lit. opg. - Met

samenvatting in het Engels.

ISBN 90-5278-155-9

Trefwoord: vaardigheden; geneeskunde-onderwijs/ toetsing;

geneeskunde-onderwijs. 


\section{Al doende leert men}

Enkele studies naar aspecten van betrouwbaarheid en validiteit over de toetsing van

vaardigheden

\section{PROEFSCHRIFT}

ter verkrijging van de graad van doctor aan de Rijksuniversiteit Limburg te Maastricht, op gezag van de Rector Magnificus Prof. dr. H. Philipsen, volgens het besluit van het College van Dekanen, in het openbaar te verdedigen op vrijdag 21 oktober 1994 om 14.00 uur

door

Scheltus Jan van Luijk

geboren te Enschede in 1950 
Promotoren:

Prof. dr. W.H.F.W. Wijnen

Prof. dr. G.G.M. Essed

Co-promotor:

Dr. C.P.M. van der Vleuten

Beoordelingscommissie:

Prof. dr. J. Drukker (voorzitter)

Dr. Tj. Imbos

Prof. dr. G. Kootstra

Prof. dr. J.C.M. Metz (Katholieke Universiteit Nijmegen)

Prof. dr. Th.B. Voom (Universiteit Utrecht) 


\section{INHOUDSOPGAVE}

Voorwoord

Inleiding

Hoofdstuk 1

Het aanleren van vaardigheden binnen een probleemgestuurd medisch curriculum

\section{Hoofdstuk 2}

Het meten van vaardigheden

\section{Hoofdstuk 3}

Het evaluatiesysteem en vaardigheidstoetsing binnen het medisch curriculum

\section{Hoofdstuk 4}

Ervaringen met vaardigheidstoetsen: het consumentenoordeel

\section{Hoofdstuk 5}

Vraagstellingen voor onderzoek

\section{Hoofdstuk 6}

Een inhoudelijke analyse van de vaardigheidstoets

\section{Hoofdstuk 7}

Een vergelijking tussen globale en analytische beoordelingen

\section{Hoofdstuk 8}

Een empirische vergelijking tussen verschillende methoden van cesuurbepaling 


\section{Hoofdstuk 9}

De predictieve validiteit van de vaardigheidstoets voor de klinische stages

Epiloog

Samenvatting

Summary

Literatuur

Bijlagen 183

Curriculum Vitae 


\section{VOORWOORD}

Het is moeilijk iedereen te bedanken die heeft meegewerkt aan de uiteindelijke vormgeving van dit proefschrift, niet in het minst omdat het maken ervan zich over een reeks van jaren heeft voltrokken. Toch wil ik een poging wagen.

Ik zou hierbij veel personen op een eerste plaats willen zetten. Tot deze personen behoren in ieder geval een groot aantal leden van de vakgroep Onderwijsontwikkeling en Onderwijsresearch en het Project Evaluatie Studieresultaten. Met name de zeer inspirerende en stimulerende rol als collega, co-promotor en vriend die Cees van der Vleuten hierbij heeft vervuld, verdient extra waardering.

Ook de collega's van het Skillslab die ik in al die jaren heb ervaren als zeer loyale medewerkers aan de diverse experimenten die in het kader van dit proefschrift behoren genoemd te worden. Met name Noël, vriend en kamergenoot, aan wie ik mijn zorgen vaak toevertrouwde, maar ook andere medewerkers waarbij met name Albert en Marleen genoemd moeten worden.

De medewerkers van Bureau Onderwijs dienen eveneens uitdrukkelijk vermeld worden. Naast vroegere medewerkers waarbij met name Marianne Vroegop genoemd moet worden met wie jarenlang "vaardigheidstoets-lief en leed" gedeeld is, verdienen ook de huidige medewerkers zeer veel waardering. Margriet, Ron, Resie, Chantal heel erg bedankt voor het mee helpen oplossen van de vele vragen die de laatste jaren op jullie zijn afgekomen.

De samenwerking met Tjaart Imbos, die mij terzijde heeft gestaan bij het toepassen van de LISREL methode in hoofdstuk negen heb ik eveneens als zeer waardevol ervaren. 
Vanzelfsprekend ook veel waardering voor de promotoren Wynand en Gerard. Met name heb ik, naast de waardevolle inhoudelijke suggesties, erg op prijs gesteld dat jullie mij de vrijheid gaven in mijn eigen tempo aan het proefschrift te werken. Dit leidde bij mij regelmatig tot een soort schuldgevoel ten aanzien van mijn vorderingen, dat mijns inziens, effectiever heeft gewerkt dan dwingende afspraken omtrent aanlevering van hoofdstukken. Bijkomend voordeel was dat mij de tijd gegund werd om wijzigingen aan te brengen op momenten dat ik dat nodig vond, hetgeen volgens mij ten goede is gekomen aan de kwaliteit van dit proefschrift.

Eén groep mensen heeft de afgelopen jaren in het bijzonder geleden onder het proefschrift. Dat zijn mijn vrienden. Vaak werden uitstapjes en vakanties geheel of gedeeltelijk door mij afgezegd omdat ik aan het proefschrift moest werken. Dat ik vervolgens thuis toch weinig deed als anderen weg waren is een realiteit die ik moeilijk onder ogen kon zien. Herman, Maarten, Ronald, Misha, en niet te vergeten Eveline bedankt voor jullie geduld en steun.

Uiteraard zijn er nog vele personen niet genoemd die ook direct of indirect betrokken zijn geweest bij voltooiing van dit proefschrift. Ik hoop jullie persoonlijk nog te kunnen bedanken. 


\section{INLEIDING}

Vaardigheden zijn belangrijk voor de beroepsuitoefening van de arts. Het dagelijks handelen van de arts bestaat voor een groot deel uit het beoefenen van vaardigheden (zoals bloeddrukmeting, onderzoek van de longen, gesprekken voeren en dergelijke). Vandaar dat in een probleemgestuurde opleiding, waarbij het leren plaats vindt aan de hand van problemen uit de medische praktijk, onderwijs in vaardigheden een belangrijke plaats inneemt.

Aan de Faculteit der Geneeskunde in Maastricht is ervoor gekozen deze vaardigheden aan te leren in wisselwerking met de inhoud van de onderwijsblokken op een speciaal daartoe ingerichte afdeling het "Skillslab".

Vanaf de start van de faculteit in 1974 heeft het Skillslab zich meer en meer ontwikkeld tot een centrum voor vaardigheidsonderwijs waar niet alleen onderwijs werd gegeven, maar ook standaarden voor lichamelijk onderzoek werden ontwikkeld (Lodewick, 1978) en trainingsmethodieken voor vaardigheidsverwerving werden toegepast.

De aandacht die binnen de faculteit bestond voor het vaardigheidsonderwijs leidde ook in een toenemende belangstelling voor de problematiek rond het toetsen van vaardigheden. Mede ingegeven door ontwikkelingen in het buitenland op dit gebied (Harden \& Gleeson, 1976) dateren de eerste stappen voor wat betreft het toetsen van vaardigheden binnen deze faculteit ook uit deze periode.

In 1980 vonden de eerste vaardigheidstoetsen plaats voor de eerste vier studiejaren. Op basis van directe observatie werden diverse vaardigheden van studenten beoordeeld onder standaard toetscondities door getrainde observatoren, gebruik makend van gestandaardiseerde checklijsten, vaak criterialijsten genoemd. Deze werden georganiseerd en administratief ondersteund door het Skillslab. De vaardigheidstoets in het zesde studiejaar werd destijds beschouwd als een toets waar ook andere 
vakgroepen verantwoordelijk voor waren. Deze toets werd min of meer onafhankelijk van de andere toetsen afgenomen.

De ontwikkelingen volgden elkaar snel op en dit leidde ertoe dat vanaf cursusjaar 1982/83 alle vaardigheidstoetsen beschouwd werden als toetsen afgenomen onder een centrale facultaire verantwoordelijkheid wat onder meer tot uiting kwam door het opnemen van vaardigheidstoetsen binnen het Examenreglement, een centrale controle op de produktie, afname en verwerking ondersteund door een eveneens centrale administratieve eenheid van het Bureau Onderwijs.

Het bewaken van de toets op centraal niveau bestaat tot op de dag van vandaag nog steeds en vindt concreet gestalte binnen het Project Evaluatie Studieresultaten (sedert 1 januari 1994 Evaluatie-Project Geneeskunde). Deze centrale bewaking is juist voor de vaardigheidstoets erg belangrijk gebleken, aangezien men zonder inzet van centrale mankracht en middelen moeilijk een dergelijk logistiek belastende toets zou kunnen organiseren. Belangrijke parameters in relatie tot de kwaliteit van de toets of toetsuitslagen kunnen worden bepaald. Eventuele consequenties hiervan kunnen direct worden meegenomen in de besluitvorming en in de verwerking van toetsresultaten.

Een ander voordeel van bewaking op centraal niveau betreft de mogelijkheden om onderzoek te verrichten naar de eigenschappen van dit meetinstrument. Gezien het feit dat het een relatief nieuw instrument is waarbij nog een groot aantal vragen beantwoord moet worden is dit een belangrijk voordeel. Zodoende is het ook mogelijk een groot aantal vragen vanuit de onderwijsorganisatie gemotiveerd en veelal onderbouwd door empirische gegevens te beantwoorden. Dit laatste speelt een belangrijke rol bij de totstandkoming van dit proefschrift.

De kern van dit proefschrift wordt gevormd door de empirische hoofdstukken zes tot en met negen. De onderwerpen voor deze hoofdstukken zijn in de meeste gevallen voortgekomen uit de vragen die vanuit de dagelijkse toetspraktijk gesteld werden en die betrokkenen bij de vaardigheidstoets letterlijk en figuurlijk bezighielden.

Een voorbeeld van $20^{\prime} \mathrm{n}$ vraag is in welke mate beoordelingscriteria voor toetsing gespecificeerd moeten worden. Mogen beoordelingscriteria globaal van vorm zijn of moeten ze juist zeer specifiek worden omschreven? En in hoeverre heeft dat consequenties voor de kwaliteit van de beoordeling van de student (hoofdstuk 7). Beoordelaars van studenten (observatoren) gaven aan dat de vaardigheidstoets in het vijfde- en zesdejaar niet representatief was voor het gegeven onderwijs, wat leidde tot een inhoudelijke analyse van de toets (hoofdstuk 6). De 
examencommissie was met name geïnteresseerd in de wijze waarop beslissingen over studenten tot stand kwamen (hoofdstuk 8) en in hoeverre uitslagen te vertalen zijn naar toekomstig gedrag in de praktijk (hoofdstuk 9). Eveneens bestond de verplichting de faculteit op de hoogte te houden van meningen van studenten en observatoren over de vaardigheidstoets als een indicator voor kwaliteitsbewaking en richtinggevend voor verder onderzoek (hoofdstuk 4).

Veel van de in het kader van dit proefschrift verzamelde gegevens zijn eerder geheel of gedeeltelijk gepubliceerd in de vorm van artikelen of congresbijdragen.

In dit proefschrift wordt gerapporteerd over aspecten van betrouwbaarheid en validiteit van de vaardigheidstoets. De inleidende hoofdstukken één tot en met vier geven het kader aan van de empirische hoofdstukken. In het eerste hoofdstuk wordt ingegaan op de vraag hoe vaardigheden kunnen worden ingedeeld en welke kenmerken te onderscheiden zijn aan vaardigheden, om vervolgens te komen tot een definitie van het begrip vaardigheid. Daarna wordt beschreven hoe studenten de vaardigheden die ze nodig hebben voor de medisch technische beroepsuitoefening aangeleerd krijgen op het Skillslab. Hierbij komen enige van de onderwijskundige uitgangspunten naar voren welke tezamen met een groot aantal praktisch organisatorische randvoorwaarden hebben geleid tot een intensief meerjarig curriculum voor vaardigheden.

In hoofdstuk twee wordt uitgelegd hoe vaardigheden gemeten kunnen worden. De toelichting wordt gericht op die vaardigheden welke betrekking hebben op de medische beroepsbeoefening. Er wordt een overzicht gegeven van de wijze van toetsing en onderzoeksresultaten met betrekking tot het evalueren van vaardigheden in diverse (voornamelijk medische) centra in de wereld.

In hoofdstuk drie wordt de positie van de vaardigheidstoets aan de Faculteit der Geneeskunde binnen het geheel van evaluatieactiviteiten weergegeven. Aan de orde komen de normstelling, de consequenties van het zakken voor de vaardigheidstoets en de relatie tussen vaardigheidstoetsing en kennistoetsing. Vervolgens komt de specifieke vormgeving en inhoud van de vaardigheidstoets aan bod. Kennis hierover is nuttig als achtergrondinformatie bij de empirische hoofdstukken.

In hoofdstuk vier wordt het "consumentenoordeel" over de vaardigheidstoets nader bekeken. Als consument worden alle bij de vaardigheidstoets betrokken studenten en stafleden beschouwd. Deze oordelen zijn tot 
stand gekomen op basis van jaarlijkse evaluaties na afloop van iedere vaardigheidstoets.

In hoofdstuk vijf worden de vraagstellingen voor het onderzoek weergegeven. Deze vraagstellingen komen voort uit de gegeven informatie van de eerste vier hoofdstukken.

Hoofdstuk zes is een empirisch gericht hoofdstuk en heeft betrekking op de inhoudsvaliditeit van de vaardigheidstoets. Nagegaan wordt in hoeverre verschillende kenmerken van vaardigheden in de vaardigheidstoets voorkomen en of dit overeenkomt met het beoogde doel van de toets. Hiertoe zijn aan alle items van een bepaalde test-kenmerken toegekend waardoor het mogelijk werd kenmerken te relateren aan toetsscores.

Hoofdstuk zeven gaat na in hoeverre er verschillen bestaan tussen het beoordelen van vaardigheden volgens een zeer gedetailleerde beoordelingslijst enerzijds en volgens een globale beoordelingslijst anderzijds. Hiertoe zijn bij dezelfde test verschillende criterialijsten gebruikt. Hoofdstuk acht vergelijkt verschillende methoden om te komen tot een cesuurbepaling bij vaardigheidstoetsen. Hierbij is uitgegaan van bestaande theorieën over het vaststellen van normen zoals die geformuleerd zijn bij kennistoetsen. Cesuren worden bepaald op grond van deze theorieën. Vervolgens worden deze cesuren vergeleken met de daadwerkelijk toegepaste zak/slaaggrens van de vaardigheidstoets. Hoofdstuk negen heeft betrekking op de voorspellende waarde van vaardigheidstoetsuitslagen (predictieve validiteit) in relatie tot het functioneren van studenten in klinische stages. Hierbij dienen de vaardigheidstoetsresultaten van de eerste vier studiejaren als voorspellers voor de studieprestaties in de laatste twee studiejaren (co-assistentschappen). Ter vergelijking is tevens de voorspellende waarde van kennistoetsresultaten nader bekeken.

In de epiloog komt vervolgens aan de orde wat al deze empirische resultaten voor de praktijk kunnen betekenen. 


\section{HET AANLEREN VAN VAARDIGHEDEN BINNEN EEN PROBLEEMGESTUURD MEDISCH CURRICULUM}

\section{Inleiding}

Het heeft relatief lang geduurd voordat onderzoek naar het aanleren van vaardigheden vorm heeft gekregen. Eén van de eerste onderzoeken op dit gebied vond plaats binnen de experimentele psychologie naar de communicatie door middel van Morse tekens (Bryan \& Harter, 1897). Behoudens deze, naar later bleek zeer relevante uitzondering, kan gesteld worden dat het onderzoek naar vaardigheden vóór de tweede wereldoor$\log$ nauwelijks vorm heeft gekregen. Sindsdien is onderzoek naar vaardigheden op gang gekomen. Dat is met name geïnduceerd door technologische ontwikkelingen die een steeds groter beroep deden op perceptuele vaardigheden en reactiesnelheid van de mens. Te denken valt hierbij bijvoorbeeld aan het ontwikkelen van steeds snellere en voor de piloot meer complexe vliegtuigen of aan de ontwikkeling van radarsystemen met de bijbehorende informatiestroom voor luchtverkeersleiders. Binnen medische en paramedische opleidingen is systematisch onderwijs van en onderzoek naar vaardigheden pas recent ontwikkeld. Het onderzoek binnen het gezondheidszorgcluster heeft een andere prioriteitsstelling dan de psychologie en onderwijskunde. Het gezondheidszorgcluster legt met name nadruk op het meten van vaardigheden bij verschillende doelgroepen binnen het medisch beroepsveld (Harden \& Gleeson, 1979; Tan, 1989), terwijl binnen de psychologie en onderwijskunde meer de nadruk ligt op processen die een rol spelen bij het verwerven van vaardigheden. 
In dit proefschrift staat de toetsing van vaardigheden centraal. De toetsing van vaardigheden is echter onlosmakelijk verbonden met het vaardigheidsonderwijs. Vandaar dat in dit hoofdstuk wordt ingegaan op vragen met betrekking tot de einddoelstellingen van het vaardigheidsonderwijs binnen de instelling en de operationalisatie daarvan in het onderwijsprogramma.

Daaraan voorafgaand dient echter eerst inzicht te worden verkregen in opvattingen over het begrip vaardigheid. Wat wordt daaronder verstaan, wat is erover bekend en welke consequenties hebben bestaande opvattingen voor de toetsing van vaardigheden?

\section{Definiëring van het begrip vaardigheid}

Velen hebben getracht het begrip vaardigheid te definiëren (Singleton, 1983; Cratty, 1964; Knapp, 1964; Van Dorp, 1977). Hierbij kan een onderscheid worden gemaakt tussen definities die meer in algemene termen worden geformuleerd, definities die meer gericht zijn op motorische vaardigheden en definities die gericht zijn op sociale vaardigheden. Wanneer men alle gegeven definities van vaardigheden probeert onder te brengen in één gemeenschappelijke definitie dan kan bijna elke bewuste activiteit van levende wezens beschouwd worden als vaardigheid. Ter illustratie volgen hier enkele voorbeelden.

Samengevat heeft Singleton (1983) de vaardigheid in algemene termen als volgt omschreven:

Een vaardigheid is een hypothetisch construct dat gebruikt wordt om gedragsveranderingen te verklaren op basis van ervaring. Het mechanisme dat ten grondslag ligt aan vaardig gedrag wordt voorgesteld als een set van patronen die zich continu aanpassen aan de realiteit. Het komen tot een bepaald doel kan volgens een "geautomatiseerd" patroon verlopen maar meestal zal de handeling zich voltrekken als gevolg van een actieve wisselwerking tussen denken en doen. Handelingen bij ervaren personen worden vaak minder bewust uitgevoerd dan bij onervaren mensen (denk bijvoorbeeld aan de autorijles en het rijgedrag een aantal jaren na het behalen van het rijbewijs). Dit zou zowel gelden voor motorische als voor sociale vaardigheden. Cratty (1964) beschrijft de vaardigheid meer in termen van zichtbaar gedrag: 
"The term skill denotes that some learning has taken place and that a smoothing or an integration of behaviour has resulted. Extraneous movements have been omitted, and the performance is executed with increasing speed and accuracy, a decrease in errors, or perhaps the ability to apply greater force. A skilled act has to be learned". Andere definities zijn duidelijker gericht op de motorische vaardigheid. Robb (1972) definieert een vaardigheid als volgt:

"A skilled movement is one in which a predetermined objective is accomplished with maximum efficiency and a minimum outlay of energy. A skilled movement does not just happen. There must be conscious effort and purposeful practice on the part of the performer in order to execute a skill".

Knapp (1964) onderscheidt drie niveau's bij de motorische vaardigheid:

- "A skill may refer to an act which arises largely through maturation such as walking, curling, twisting and other acts of this kind in their more elementary stages. These acts have also been called activities, fundamental skills and basic skills. Since skill is learned and these acts are largely unlearned it would be best not to use the term skill but to call these basic movements. Practice of these basic movements which do not have a clearly defined goal keeps them in action and ready to be called on when needed".

- "A skill may refer to an act in which the aim is the production of some pattern of movements which is considered to be technically sound for the particular skill and which is an integral part but not the whole part of that skill".

- "A skill may refer to an act or a whole collection of actions in which there is a clearly defined goal or a set of goals. It will include the skills in which the technique plays the major part and also in which the reactions of the environment becomes vital".

Naast de motorische vaardigheden worden ook vaardigheden onderscheiden die gericht zijn op communicatie met een patiënt. Voor dit type vaardigheid bestaat een groot aantal synoniemen. Zo spreekt men van anamnese, anamnestisch onderzoek, medisch interview, sociale vaardigheid, gesprekstechniek, cognitieve vaardigheid, communicatieve vaardigheid, communicatie vaardigheid, interpersoonlijke vaardigheden en dergelijke.

Inhoudelijk worden bovenstaande termen deels gekenmerkt door elementen die in de voorafgaande definities aan de orde zijn geweest, deels worden er nieuwe aan toegevoegd. Volgens Singleton (1983) bezitten sociale vaardigheden de volgende unieke eigenschap: het betreft 
vrijwel uitsluitend een uitwisseling van informatie die sterk gerelateerd is aan de persoonlijkheidsstructuur van de actoren. Hij die het best in staat is op de informatieuitwisseling te anticiperen is het meest sociaal vaardig.

Een medisch interview wordt volgens Van Dorp (1977) omschreven als een verzameling van vragen die gesteld moeten worden om tot een adequate definitie van het probleem of de problemen van de patiënt te komen.

Hess (1969) maakt binnen een medisch interview een onderscheid tussen interpersoonlijke en communicatieve vaardigheden. Interpersoonlijke vaardigheden hebben te maken met het wederzijds vertrouwen tussen de actoren en met de acceptatie van elkaar. Communicatieve vaardigheden hebben te maken met de hoeveelheid informatie tussen de actoren en met de elementen die hierbij van invloed kunnen zijn, zoals de structurering van het gesprek, samenvatten, uitleg geven en dergelijke.

Tabel 1: $\quad$ Aantal algemene kenmerken van vaardigheden die regelmatig in de literatuur naar voren komen.

Algemene kenmerken:

- Een vaardigheid is een continue activiteit

- Alle stadia van informatieverwerking worden bij het toepassen van een vaardigheid doorlopen (input, process, outcome)

- Het toepassen van vaardigheden is aangeleerd gedrag

- Elke vaardigheid heeft een betekenis of doel

- Een vaardigheid bezit een hoge mate van complexiteit

- Een vaardigheid is een gestructureerde/georganiseerde handeling

- Een vaardigheid is het toepassen van kennis

- Een vaardigheid staat in "open communicatie" met de buitenwereld

Kenmerken specifiek gericht op motorische vaardigheden:

- Het toepassen van een vaardigheid vereist een hoge mate van coördinatie van bewegingen

Kenmerken specifiek gericht op sociale vaardigheden:

- Een vaardigheid is het uitwisselen van en anticiperen op (non) verbale informatie

Kraan en Crijnen (1987) onderscheiden daarnaast binnen het medisch interview ook nog de complexe interview-vaardigheden waarmee wordt bedoeld het confronteren van de patiënt met (eigen) tegenstrijdige informatie en de vaardigheid van het bijdragen aan de bewustwording 
van de patiënt van het probleem (bijvoorbeeld door reflecteren van gevoelens), zodat gemakkelijker alternatieven door de hulpverlener kunnen worden aangedragen.

Wanneer men bovenstaande definities gericht op de verschillende dimensies binnen het vaardigheidsbegrip met elkaar vergelijkt, komen daarin een groot aantal elementen voor die kenmerkend zijn voor alle vaardigheden. Tabel 1 geeft hiervan een overzicht.

Op basis van het voorafgaande de volgende definitie van een psychomotorische vaardigheid kunnen hanteren:

"Een psychomotorische vaardigheid is doelgericht aangeleerd psychomotorisch gedrag op basis van kennis, waarbij meestal sprake is van een complex continu bewegingspatroon, dat een hoge mate van coördinatie vereist in open communicatie met de buitenwereld".

Hierbij dient overigens wel opgemerkt te worden dat de begrippen "complex" en "hoge mate van coördinatie" afhankelijk zijn van degene die de vaardigheid beoefent. Dit zal voor een eerstejaars student anders liggen dan voor een zesdejaars student.

$\mathrm{Bij}$ de sociale vaardigheden is er eveneens sprake van doelgericht aangeleerd gedrag, echter deels op basis van kennis en deels op basis van zintuiglijke waarnemingen en gedragingen (verbaal, non-verbaal gedrag, emotionele geladenheid). Eveneens is er sprake van een complex gedragspatroon dat een hoge mate van integratie (van cognitieve en soms psychomotorische patronen) vereist. Op grond hiervan kan de volgende definitie gegeven worden:

"Een sociale vaardigheid is doelgericht aangeleerd sociaal gedrag, deels op basis van kennis en deels op basis van zintuiglijke waarnemingen en gedragingen. Dit leidt tot een complex gedragspatroon dat een hoge. mate van integratie en aanpassing van diverse cognitieve en psychomotorische patronen vereist in open communicatie met de buitenwereld".

\section{Definiëring van het begrip vaardigheid binnen het onderwijs en evaluatieprogramma}

Komen de beschrijvingen van het begrip vaardigheid in de voorafgaande paragrafen, voornamelijk bepaald vanuit de psychologie en onderwijskunde, overeen met de definiëring van het begrip vaardigheid zoals dit 
gehanteerd wordt binnen het onderwijs- en toetsingsprogramma aan de Faculteit der Geneeskunde in Maastricht?

Het gegeven onderwijs en het toetsen van vaardigheden zijn primair gericht op het leren en het meten van vaardigheden in relatie tot de toekomstige beroepsuitoefening. Dientengevolge is de in de onderwijsen toetspraktijk geldende definitie van een vaardigheid sterk op de praktijk afgestemd. Dit heeft twee consequenties ten aanzien van de definiëring van het begrip. Ten eerste wordt de omvang van het vaardigheidsbegrip gekoppeld aan de eindtermen van de opleiding. Ten tweede wordt de interactie tussen vaardigheden en kennis -gezien het belang van de praktische beroepsuitoefening- als een essentieel onderdeel van de te beheersen vaardigheden gezien.

Rekening houdend met en in aanvulling op de eerder in dit hoofdstuk vermelde definities wordt in dit proefschrift de volgende definitie van een psychomotorische vaardigheid gegeven:

"Een psychomotorische vaardigheid bestaat uit doelgericht aangeleerd gedrag op basis van kennis, waarbij meestal sprake is van een complex continu bewegingspatroon dat een hoge mate van coördinatie vereist in open communicatie met de buitenwereld inclusief de interactie van die vaardigheid met andere medische competentie domeinen (kennis en attitude). Deze vaardigheid behoort tot de medische handelingen die relevant zijn voor de eindtermen van de basisopleiding".

De beschrijving van de "sociale vaardigheid" wordt als volgt gedefinieerd:

"Een sociale vaardigheid is doelgericht aangeleerd (sociaal) gedrag, deels op basis van kennis en deels op basis van zintuiglijke waarnemingen en gedragingen. Dit leidt tot een complex gedragspatroon dat een hoge mate van integratie en aanpassing van diverse cognitieve en psychomotorische patronen vereist in open communicatie met de buitenwereld. Deze vaardigheid behoort tot de medische handelingen die relevant zijn voor de eindtermen van de basisopleiding ".

Bovenstaande definities geven aan dat het begrip vaardigheid gekoppeld wordt aan de eindtermen van de opleiding. Dit is een belangrijk gegeven voor de opbouw van het vaardigheidscurriculum (dit hoofdstuk) en het toetsen van vaardigheden (hoofdstuk 2). 


\section{Het ontstaan en de plaats van het onderwijs in vaardigheden binnen het medisch onderwijs}

Vaardigheidsonderwijs is al sedert het ontstaan van de geneeskunde onlosmakelijk verbonden met de medische opleiding. In de vorige eeuw was het onderwijs deels gebaseerd op een "meester - gezel - relatie". De student liep mee met zijn leermeester en werd in de geheimen van het vak ingewijd: "al doende leerde men". De leermeester bepaalde wanneer zijn pupil over voldoende vaardigheden en kennis beschikte om in de maatschappij zijn beroep te kunnen uitoefenen.

Eind vorige eeuw werd op geleide van de ontdekkingen van Koch en Pasteur steeds meer aandacht besteed aan de vakken die verklaringen aandroegen voor ziektebeelden. De medische opleiding werd steeds theoretischer en gericht op een grote verscheidenheid van specialismen. Deze tendens werd versterkt door het zogenaamde "Flexner rapport" $(1910,1912)$, waarin het slechte functioneren van artsen aan de gebrekkige theoretische opleiding werd toegeschreven. Dit leidde in de Angelsaksische landen en later ook elders tot een onderwijssysteem dat begon met een aantal jaren theoretisch onderwijs. Vervolgens moest gedurende een bepaalde tijd een stageperiode in de praktijk van de gezondheidszorg worden doorlopen. Daarbij diende het praktisch onderwijs veelal ter illustratie van theoretische principes. Alleen in de stages aan het eind van de studie werd aandacht geschonken aan het praktisch functioneren als arts. Met veel vallen en opstaan en vaak ten koste van de patiënt moest de student zich de vaardigheden eigen maken. $\mathrm{Bij}$ studenten en onderwijsgevers ontstond aan het eind van de jaren zestig veel onvrede met het gebruikelijke onderwijsmodel voor vaardigheden. Deze onvrede werd nog versterkt door de explosieve groei van het aantal medische studenten, waardoor tijdens de stages als het ware een "gevecht om de schaarse patiënt" ontstond. De introductie van de zogenaamde "junior-coschappen" in het medisch curriculum aan het begin van de jaren zeventig werd onder meer gezien als antwoord op de vraag om meer praktisch onderwijs.

De Faculteit der Geneeskunde van Maastricht heeft vanaf de start in 1974 geprobeerd oplossingen aan te dragen voor dit gemis aan voorbereiding op het praktisch functioneren als arts. Daarom werd als één van de uitgangspunten van het Maastrichtse onderwijssysteem gekozen voor vroegtijdige en over het gehele curriculum gespreide contacten met de praktijk van de gezondheidszorg. Eén van de voorwaarden voor deze praktijkcontacten, is dat studenten vanaf de start 
van het curriculum voorbereid worden op de praktische kanten van deze stages. Er is voor gekozen deze voorbereiding te laten plaatsvinden in het Skillslab. Vaardigheidsonderwijs in een laboratoriumsituatie heeft een aantal didactische, ethische en praktische voordelen ten opzichte van leersituaties in de reguliere patiëntenzorg. Genoemd kunnen worden de volgende punten:

- in een laboratoriumsituatie is het mogelijk complexe situaties zoals die zich in de praktijk van de gezondheidszorg voordoen uiteen te rafelen tot eenvoudige, goed te oefenen deelvaardigheden. Anders gezegd, men kan de moeilijkheidsgraad en de complexiteit van de leersituatie controleren en doseren

- in een laboratoriumsituatie is het mogelijk iedere student een gedifferentieerd aanbod aan patiëntenproblemen te geven door gebruik te maken van modellen, studenten zelf of simulatiepatiënten

- in een laboratoriumsituatie kan men een vaardigheid zo vaak als nodig is herhalen, bij echte patiënten is dit veelal ongewenst en meestal ontoelaatbaar.

- in een laboratoriumsituatie mag men fouten maken

- in een laboratoriumsituatie is directe feedback mogelijk

- problemen van patiënten die zich in werkelijkheid soms over een reeks van jaren afspelen, kan men in een gesimuleerde situatie in fasen (gedoseerd) aanbieden.

- kennis en vaardigheidsonderwijs kunnen ondersteunend en stimulerend werken ten opzichte van elkaar

- het aanleren van vaardigheden in een laboratoriumsituatie maakt de klinische stages effectiever voor de student en vermindert de docentbelasting binnen de stages.

Behalve patiënt- en mogelijk ook docentsparend, werkt vaardigheidsonderwijs in een laboratoriumsituatie ook studentsparend namelijk,

- vaardigheidsonderwijs werkt motiverend (Schmidt \& Moust, 1981), wat de kans op studievertraging/studie-uitval verkleint

- vaardigheidsonderwijs geeft de student een vroegtijdig en zeer duidelijk beeld van zijn toekomstig beroep. Het voordeel hiervan is dat er snel een zekere bewustwording optreedt ten aanzien van de eigen geschiktheid voor de toekomstige beroepsuitoefening. 
Een ander belangrijk voordeel van systematisch vaardigheidsonderwijs is dat de onderwijsgevenden verplicht worden de vaardigheden eenduidig vast te leggen, zodat de studenten niet in de war gebracht worden door de verschillende varianten van een bepaald type onderzoek. Voor dit doel wordt gebruik gemaakt van gedetailleerde schriftelijke instructies vooraf, de zogenaamde "standaarden". Dit zijn stapsgewijze gedetailleerde beschrijvingen van handelingen die verricht moeten worden bij het lichamelijk onderzoek van een patiënt.

Het protocolleren van een vaardigheid heeft als voordeel dat daarmee de overdraagbaarheid van onderzoeksbevindingen met betrekking tot lichamelijk onderzoek of laboratoriumbepalingen bevorderd wordt, indien iedereen dergelijke bevindingen heeft verzameld volgens de door het protocol omschreven methode.

Het aanleren van één methode heeft een groot didactisch voordeel, ten opzichte van het aanleren van verschillende varianten van onderzoek. Men kan binnen dezelfde tijdseenheid meer aandacht besteden aan één methode, waardoor de kans dat die methode beklijft veel groter is in vergelijking tot het aanleren van de varianten.

Het protocolleren van vaardigheden maakt het eveneens mogelijk dat dergelijke onderwijsactiviteiten eenvoudiger getoetst kunnen worden, omdat men een "gouden standaard" heeft waarvan criterialijsten afgeleid kunnen worden.

Uitgebreide beschrijvingen van een vaardigheid zullen vaak niet overeenkomen met de uitvoering van de vaardigheid zoals die in de praktijk wordt uitgevoerd. Het is echter niet erg als studenten tijdens het leerproces de ideale methode van onderzoek leren ervan uitgaande dat de "standaard" de ideale methode weergeeft. De ervaring uit de praktijk zorgt er dan voor om in te schatten welke onderdelen in welke situaties minder relevant zijn. Om echter die keus te kunnen maken moet het model onderzoek wel beheerst worden.

Het gedetailleerd uitschrijven van handelingen in de vorm van standaarden heeft echter ook nadelen. Zo zou de motivatie van studenten om zelf proberen te beredeneren op welke manier een bepaalde handeling het best kan worden uitgevoerd gereduceerd worden. Deze laatste (actieve) manier van kennisverwerving zou een gunstig effect hebben op het leerrendement (Newble en Entwistle, 1986) en daarmee een positieve invloed kunnen hebben op (het cognitieve element van) de vaardigheid. Desalniettemin kan de vraag gesteld worden of dit nadeel groot is. Zeker gezien de bevindingen van Welford (1958) waaruit blijkt dat de "kennismaking" met de vaardigheid sterk bepalend is voor de 
manier waarop het vaardigheidsniveau zich verder ontwikkelt. Hiervan uitgaande lijkt het in dit verband onverstandig alleen uit te gaan van de theorie dat mensen leren van hun eigen fouten. Een ander punt van kritiek op de zeer gedetailleerde protocollen is dat studenten soms meer geneigd zijn om te "leren" voor de vaardigheid dan om de vaardigheid te "oefenen" omdat ze eerst willen "kennen" voordat ze wat iets willen "kunnen". Als studenten in die kennisfase blijven steken is dat een gegeven dat in eerste instantie strijdig is met de opzet van vaardigheidsonderwijs. Het "leren" en "kennen" kan tevens ook in de hand gewerkt worden door de waardering die gehecht wordt (door docenten of/en de manier van evalueren) aan het weergeven van vaardigheidskennis. Recent zijn dergelijke protocollen ook voor huisartsen verschenen (Boumans \& Ooy, 1990). Eveneens is het Nederlands Huisartsen Genootschap (Rutten et al., 1993) overgegaan tot het formuleren van standaarden. Het standaardiseren van vaardigheden heeft behalve onderwijskundige voordelen, ook het voordeel dat de overdraagbaarheid van onderzoeksgegevens groter wordt.

$\mathrm{Al}$ deze zaken hebben ertoe geleid dat het Skillslab in Maastricht na een voorzichtige start tot grote bloei is gekomen. Het Skillslab vormt hiermee een belangrijke inspiratiebron voor andere medische faculteiten binnen en buiten Nederland.

\section{De vormgeving van het vaardigheidsonderwijs binnen het probleemgestuurd onderwijs}

Het belangrijkste doel van het Skillslab is het aanleren van vaardigheden bij studenten zodanig dat in de praktijk van de gezondheidszorg deze vaardigheden gericht, juist en geïntegreerd worden uitgevoerd. De manier waarop het aanleren van deze vaardigheden binnen het Skillslab is gerealiseerd wordt in de volgende paragraaf uitgelegd.

Doelstellingen van het vaardigheidsonderwijs

De vaardigheden die nodig zijn om aan de einddoelstellingen van de opleiding tot basisarts te voldoen kunnen worden onderverdeeld in een aantal clusters. Deze clusters van vaardigheden zijn de volgende: 
- fysisch-diagnostische vaardigheden, bijvoorbeeld het onderzoek van het hart, het onderzoek van de knie of het onderzoek van de zwangere vrouw;

- sociale vaardigheden, bijvoorbeeld leren samenvatten, het voeren van een voorlichtingsgesprek of het voeren van een slecht nieuws gesprek;

- laboratoriumvaardigheden, bijvoorbeeld het maken van een bloeduitstrijkje, het beoordelen van een urinesediment of het bekijken van wormeieren in de faeces;

- therapeutische vaardigheden, bijvoorbeeld het leggen van diverse soorten verbanden, intuberen, hartmassage of injecteren.

Van al deze clusters van vaardigheden (uitgezonderd sociale vaardigheden) dient de student de volgende stappen te beheersen (voor zover van toepassing):

- de techniek van de vaardigheid

- de systematiek van de vaardigheid

- het inschatten van de normale fysiologische variabiliteit bij (lichamelijk) onderzoek

- het genereren van hypothesen over mogelijke ziektebeelden op grond van bepaalde onderzoeksbevindingen

- het bepalen van vervolgonderzoek

- het schrijven van een verslag met betrekking tot de resultaten van een onderzoek.

Voor de sociale vaardigheden geldt dat de student de volgende vaardigheden moet beheersen:

- de techniek van de gespreksvoering

- de systematiek van de gespreksvoering

- het kunnen toepassen van bepaalde gespreksmodellen

- het goed kunnen functioneren binnen specifieke gesprekssituaties

- het schrijven van een verslag met betrekking tot de resultaten van een gesprek.

Het voorafgaande heeft alleen betrekking op de vier separate clusters van vaardigheden. Daarnaast wordt er binnen het vaardigheidsonderwijs expliciet aandacht besteed aan integratiemomenten tussen de vaardigheden enerzijds en tussen vaardigheden en kennis anderzijds. Dit gebeurt 
op verschillende manieren, bijvoorbeeld door contacten met (simulatie)patiënten en door de aansluiting van het vaardigheidsonderwijs met de thematiek in de onderwijsblokken.

De aangeboden onderwijspakketten worden samengesteld in overleg met vakgroepen. Zo dragen bijvoorbeeld ook vertegenwoordigers van de vakgroep Anatomie en Orthopedie bij aan het pakket vaardigheden met betrekking tot het bewegingsapparaat. Op een vergelijkbare manier wordt het pakket sociale vaardigheden voortdurend "gevoed" door een projectgroep waarin ondermeer vertegenwoordigers uit de gedragswetenschappelijke vakgroepen zitting hebben.

\section{Het trainingsprogramma van vaardigheden in de praktijk}

Studenten dienen zich over het algemeen van te voren in te schrijven voor elke aangeboden training. Een overzicht van alle aangeboden trainingen is te vinden in bijlage 1 . Het participeren aan vaardigheidstrainingen vindt plaats op vrijwillige basis. Heeft men zich eenmaal ingeschreven dan is deelname verplicht. Er bestaan naast docentbegeleide trainingen ook docent-onafhankelijke trainingen. Hierbij oefenen studenten met elkaar aan de hand van werkboeken. Een docent is op afroep beschikbaar.

Het blijkt dat vrijwel alle studenten deelnemen aan het vaardigheidsprogramma. Ongeveer $85 \%$ van de vaardigheidstrainingen is een rechtstreeks gevolg van het programma-aanbod in de blokboeken. De resterende $15 \%$ wordt ingevuld met herhalingstrainingen, trainingen die te maken hebben met specifieke wensen van studenten, met activiteiten binnen een keuzeblok of remedial teaching.

Naast het aanbieden van trainingen worden er ook simulatiepatiëntencontacten georganiseerd, gemiddeld twee maal per blok. Hierop wordt later nog ingegaan.

Van studenten wordt verwacht dat ze zich voorbereiden op de trainingen met behulp van boeken, audio-visuele hulpmiddelen en standaarden. Hieronder volgt een korte beschrijving van de verschillende soorten trainingen die worden aangeboden.

Trainingen in fysisch-diagnostische vaardigheden, therapeutische vaardigheden en laboratoriumvaardigheden

De trainingen in fysisch-diagnostische vaardigheden, therapeutische vaardigheden en laboratoriumvaardigheden hebben qua uitvoering dezelfde opzet. Gemiddeld hebben studenten vier tot zes trainingen per 
blok. Dit betekent maximaal één training per blokweek. Studenten schrijven zich hiervoor in, vrijwel altijd in groepen van acht tot tien personen. Voor deze groepsgrootte geldt in de praktijk dat een adequate begeleiding door de docent net haalbaar lijkt gezien de doelstelling van de trainingen.

Verder speelt de mate van intimiteit een rol bij het bepalen van de groepsgrootte. Zo worden bij het onderzoek van de mannelijke en vrouwelijke genitalia bij specifiek daarvoor getrainde onderzoeksmedewerkers(sters) slechts één of twee studenten toegelaten tot de training. Ten aanzien van de inhoud van de training geldt dat stapsgewijs een vooraf bepaald leerdoel in de training moet worden bereikt. Hiertoe is het meestal noodzakelijk dat een student de gegeven voorbereidingsadviezen opvolgt. De gemiddelde voorbereidingstijd is ongeveer even lang als de tijdsduur van een training, dus gemiddeld anderhalf uur.

De meeste trainingen van dit type vaardigheden worden separaat, dat wil zeggen in "losse" eenheden van anderhalf uur aangeboden, dat betekent dat de groepssamenstelling per training kan wisselen. Een aantal trainingen echter wordt wel als cluster aangeboden waarbij de groepssamenstelling hetzelfde blijft. Het voordeel van deze laatste methode is dat docenten en studenten zelf enige vrijheid hebben hoe de trainingen worden ingedeeld, als maar binnen een vooraf afgesproken hoeveelheid tijd bepaalde leerdoelen bereikt worden.

De trainingen hebben het eerste jaar het karakter van kennismaking met de diverse typen vaardigheden. In de latere studiejaren moeten inhoud en vormgeving van de training zoveel mogelijk lijken op de praktijk van de gezondheidszorg. Dit betekent dat het vaardigheidsonderwijs in de latere studiejaren zoveel mogelijk aan de hand van patiëntenproblemen wordt aangeboden. Op die manier wordt het mogelijk niet alleen de techniek van de handeling te oefenen, maar ook de relatie tussen kennis en vaardigheden inzichtelijk te maken, conform de opvatting die aan de instelling bestaat omtrent het begrip vaardigheid (zie hoofdstuk 1).

\section{Trainingen sociale vaardigheden}

De trainingen sociale vaardigheden zijn anders georganiseerd dan de overige trainingen. Studenten worden vanaf het begin van het studiejaar ingedeeld in vaste groepen van 10 personen die het gehele jaar bij elkaar blijven.

De opbouw van de trainingen is zodanig dat in het eerste jaar een aantal basisvaardigheden (bijvoorbeeld samenvatten, observeren, vraagverhelde- 
ring) wordt aangeleerd, en in de jaren daaropvolgend steeds meer toegewerkt wordt naar meer complexe gesprekssituaties zoals counselingsgesprek, voorlichtingsgesprek, gesprekken met echtparen en dergelijke. Uiteraard komen in de hogere jaargroepen in toenemende mate andere aspecten van de arts-patiëntrelatie dan de zuivere gesprekstechnische vaardigheden aan bod, zoals bijvoorbeeld attitude. Ook hier is, evenals bij de fysisch diagnostische vaardigheid, sprake van interactie tussen het vaardigheidsdomein en een ander domein (in dit geval attitude) zodat dit ook hoort tot de te onderwijzen en te toetsen leerstof conform de definitie van vaardigheid in hoofdstuk 1.

In deze trainingen oefenen studenten de gesprekstechnische vaardigheden met name met elkaar. Binnen de trainingen wordt vaak naar aanleiding van opdrachten van de begeleider of videobanden, rollenspellen door studenten gespeeld. Hierbij wordt gediscussieerd over de vraag welke (gespreks)interventies goed of minder goed zouden overkomen bij een patiënt en welke alternatieven men kan geven voor een zo goed mogelijk verlopend gesprek gezien het probleem dat aangeboden wordt.

In tegenstelling tot de trainingen van fysisch diagnostische en therapeutische vaardigheden verlopen de trainingen bij sociale vaardigheden niet aan de hand van standaarden. Het lijkt niet mogelijk te zijn om het voeren van een gesprek in "standaard vorm" vast te leggen aangezien de interactieve component tijdens een gesprek groter is dan tijdens een lichamelijk onderzoek. Wel is het zo dat er afspraken bestaan over de vorm van het gesprek (de volgorde waarin één en ander moet worden gevraagd) en de manier waarop men de eerder genoemde basisvaardigheden toepast (Schouten, 1982).

\section{Onderwijsactiviteiten gericht op de integratie van vaardigheden}

De integratie tussen de diverse vaardigheden wordt nagestreefd op verschillende niveaus. Als eerste dient hierbij de bestaande trainingsinhoud en trainingsopbouw genoemd te worden. Zoals reeds eerder aangeduid start het eerste studiejaar met relatief eenvoudige handelingen op een beperkt terrein. In het derde en vierde studiejaar krijgen studenten problemen van patiënten aangeboden aan de hand waarvan de relevante vaardigheden geoefend moeten worden.

Separaat van de trainingen binnen de clusters fysisch diagnostische. therapeutische, laboratorium en sociale vaardigheden, vinden er ook activiteiten plaats welke gericht zijn op de integratie van de bovengenoemde clusters van vaardigheden. De onderwijsactiviteiten die hieraan bijdragen zijn de (simulatie)patiënten- contacten, bejaarden- 
contacten, gynaecologisch en andrologisch onderzoek op getrainde proefpersonen. Hierop wordt verder in dit hoofdstuk ingegaan.

Voor de simulatiepatiëntencontacten (Phaff, 1987) geldt dat elke student vanaf het derde blok van het eerste jaar gemiddeld éénmaal per blok een contact heeft met een simulatiepatiënt. Vanaf het tweede jaar heeft de student tweemaal per blok een contact. Tijdens dit contact is het de bedoeling dat de student een geheel consult voert al naar gelang zijn eigen kennen en kunnen. De klachten die simulatiepatiënten presenteren zijn grotendeels gerelateerd aan de casuïstiek die in de onderwijsblokken wordt besproken. Naast de integratie van de diverse vaardigheden wordt in dergelijke contacten tevens een beroep gedaan op medische kennis waardoor de student kan leren "medisch competent" te handelen. De gesprekken met de simulatiepatiënten worden aan de hand van een video-opname nabesproken. Verschillende studenten van dezelfde groep hebben een simulatiepatiënt met dezelfde klacht gehad zodat ervaringen kunnen worden uitgewisseld.

Integratie van de vaardigheden vindt ook plaats bij de zogenaamde "bejaardencontacten" (Franssen, et al., 1992). Hierbij gaan derdejaars studenten éénmaal per zes weken naar een bejaardentehuis om paarsgewijs de bewoners te interviewen over hun medische voorgeschiedenis gevolgd door een gericht lichamelijk onderzoek en een nabespreking met diverse hulpverleners. Op deze manier worden studenten al vroeg in hun studie in staat gesteld allerlei lichamelijke afwijkingen te onderkennen.

Ook het contact met echte patiënten die de student tijdens de eerste vier jaren van zijn studie ziet draagt op dezelfde wijze bij tot de integratie van de diverse vaardigheden.

Aparte contacten worden georganiseerd met medewerk(st)ers die bereid zijn door studenten onderzocht te worden aan hun gesiachtsorganen (Phaff \& Spronken, 1987). Het doel is het oefenen van het gynaecologische onderzoek en het onderzoek van de mannelijke genitalia. Daarnaast staat echter ook het contact met de medewerk(st)ers centraal bij dit emotioneel beladen onderzoek. De medewerk(st)er is geïnstrueerd de student feedback te geven met betrekking tot haar of zijn beleving van het onderzoek (bijvoorbeeld geen duidelijke instructie met betrekking tot ontkleding, geen privacy, onderzoek te houterig en dergelijke).

De ervaring leert dat trainingen die gericht zijn op de integratie van vaardigheden als zeer zinvol worden ervaren door zowel de student als de docent. Door middel van een dergelijk onderwijsaanbod wordt de student nadrukkelijk geconfronteerd met zijn vorderingen op het gebied 
van de medische competentie en dus met de latere beroepsuitoefening hetgeen een motiverende invloed kan hebben op komende studieactiviteiten.

Uit de diverse programma-evaluaties van het vaardigheidsonderwijs blijkt evenals uit interne visitatierapporten (Leeuw et al., 1992), dat de student in het algemeen zeer tevreden is met het aangeboden vaardigheidsonderwijs. Deze vorm van onderwijs is dan ook niet meer weg te denken uit het Maastrichtse curriculum. De oorspronkelijke argumenten om te komen tot een Skillslab blijken nog altijd te gelden. 


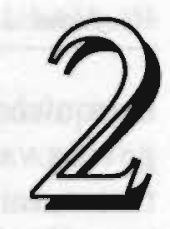

\section{HET METEN VAN VAARDIGHEDEN}

\section{Inleiding}

Aan het eind van de zeventiger jaren werd duidelijk dat het meten van kennis en het beoordelen daarop alleen geen recht deed aan de veelzijdige taak welke een basisarts op zich diende te nemen na afloop van zijn opleiding. Meer en meer werd ingezien dat studenten ook op andere aspecten van medische competentie getoetst zouden moeten worden (GPEP rapport, 1984). Voor zover andere onderdelen dan kennis in examens werden beoordeeld gebeurde dit op een weinig systematische wijze. Bovendien werden de beoordelingen in het algemeen als zeer subjectief beschouwd. In de regel werden examens afgenomen door één docent die een beperkt aantal onderwerpen aan de orde stelde en op basis daarvan een oordeel uitsprak over de kandidaat.

Deze kritiek heeft er onder meer voor gezorgd dat het toetsen van vaardigheden de laatste twintig jaar een enorme vlucht heeft genomen. Hierbij zijn met name twee stromingen te onderkennen. De ene stroming betreft de ontwikkeling van de Objective Structured Clinical Examination (OSCE) in Engeland (Harden \& Gleeson, 1979) en de andere stroming -een variant van de eerste- behelst de ontwikkeling van de Standardized Patient-based testen (Williams et al., 1987; Stillman et al., 1989) in de Verenigde Staten. In dit hoofdstuk worden deze beide stromingen beschreven. Gezien het feit dat boven bedoelde ontwikkelingen ondermeer zijn voortgekomen uit het feit dat beoordelingen in het verleden te subjectief waren, wordt vervolgens besproken of de 
betrouwbaarheid van de beoordeling in positieve zin veranderd is als gevolg van de ontwikkelingen de afgelopen jaren op het gebied van het meten van vaardigheden. Eveneens zullen verschillende aspecten betreffende de validiteit van dit soort toetsen aan de orde komen.

\section{Objective Structured Clinical Examinations (OSCE)}

In 1979 kwamen Harden \& Gleeson met het idee van een zogenaamde "Objective Structured Clinical Examination" (OSCE). Dit is een examen primair gericht op het uitvoeren van vaardigheden en eventueel daaraan gerelateerde kennis gegeven een bepaalde casus. Hierbij moet een student gemiddeld zo'n 15-20 opdrachten in verschillende ruimten, stations genoemd, uitvoeren. De gemiddelde tijdsduur van dergelijke toetsen bedraagt twee á drie uur. OSCE's worden met name geconstrueerd voor studenten die zich in de klinische fase van de studie bevinden. De inhoud is derhalve ook sterk op klinische problemen van de desbetreffende disciplines georiënteerd. Hierbij ligt de nadruk met name op chirurgische en interne problematiek (Mann et al., 1990; Petrusa et al., 1987-B; Lunefeld et al., 1991), hoewel andere vakgebieden ook steeds meer aan bod komen (Famuyiwa et al., 1991).

Een klassiek "stationsexamen" houdt meestal het volgende in (Metz, 1984): Studenten moeten in diverse stations opdrachten uitvoeren gericht op het medisch handelen. Deze opdrachten zijn meestal in 5 minuten uit te voeren (bijvoorbeeld: sla de reflexen aan de armen; beschrijf de afwijking op de röntgenfoto) en hebben soms een voorgeschreven volgorde, als een bepaald probleem gesimuleerd moet worden. De inhoud van ieder station kan sterk wisselen afhankelijk van de aard van de aangeboden opdrachten en het inhoudelijke onderwerp (domein) waarover getoetst wordt.

De opdrachten zijn zodanig opgesteld dat niet noodzakelijkerwijs bij ieder station een beoordelaar aanwezig hoeft te zijn. Zoals in het boven genoemde voorbeeld betreffende de beoordeling van een röntgenfoto, wordt van de student om een interpretatie gevraagd, welke vervolgens op schrift gesteld moet worden. Een beoordelaar is hierbij niet nodig. Evenzo kan het voorkomen dat een student een kort samenvattend verslag van de anamnese moet schrijven, een differentiaal diagnose moet opstellen of een aantal vragen moet beantwoorden naar aanleiding van 
een patiënt (of een ziekte) welke centraal stond in het zojuist doorlopen station. De vorm van de toets, het toepassen van diverse vormen van schriftelijke toetsing naast toetsing door middel van observatie, kan derhalve binnen één OSCE wisselen.

Vaardigheden binnen een OSCE worden vaak beoordeeld aan de hand van gedetailleerde criterialijsten. Deze lijsten hebben meestal de vorm van een "checklijst". Er hoeft alleen maar "gecheckt" te worden door een beoordelaar (observator) of een student een bepaalde vaardigheid heeft verricht of niet. Dergelijke criterialijsten worden door observatoren vaak als restrictief gezien (Newble, 1988).

In het algemeen ligt bij het toetsen van de vaardigheid de nadruk op het technisch correct uitvoeren van de opeenvolgende stappen van een vaardigheid. Resultaten of conclusies naar aanleiding van het verrichte onderzoek worden meestal in schriftelijke (vervolg-)stations getoetst waarbij geen observator aanwezig is. Observatoren zijn doorgaans stafleden die afkomstig zijn uit de disciplines waarover wordt getoetst.

Tabel 1: Voorbeeld van een circuit van stations representatief voor een Objective Structured Clinical Examination (Harden en Gleeson, 1979).

Anamnese bij een kortademige patiënt (1)* Beoordeling van een dia van een patiënt $(2)^{*}$ Vragen naar aanleiding van station 1 Vragen naar aanleiding van station 2

Neurologisch onderzoek $(3)^{*}$

Vragen naar aanleiding van station 3

Inspectie van een röntgenfoto (5)

Vragen naar aanleiding van station 5

Urineonderzoek (7)

Vragen naar aanleiding van station 7

Beoordeling Elektrocardiogram (9)

Vragen naar aanleiding van station 9
Anamnese bij een patiënt met haematurie (4)* Vragen naar aanleiding van station 4

Onderzoek van de buik (6)*

Vragen naar aanleiding van station 6

Anamnese bij patiënt met lage rugpijn (8)*

Vragen naar aanleiding van station 8

Onderzoek van het hart (10)*

Vragen naar aanleiding van station 10

1) Alle stations duren 4-5 minuten.

2) Bij de met * gemerkte stations is een observator aanwezig

Het beoordelen wordt over het algemeen als "zwaar" en "belastend" gezien (Harden \& Gleeson, 1979; Newble, 1988). 
In Tabel 1 is een voorbeeld van een OSCE weergegeven (Harden en Gleeson, 1979).

\section{De Standardized Patient-Based Test (SP-based testen)}

Naast de ontwikkeling en opkomst van de OSCE in Europa, ontstond er ook in de Verenigde Staten en Canada een soortgelijke behoefte aan een meetinstrument dat betrouwbaar het dagelijks handelen van (toekomstige) artsen zou vastleggen.

Er werd een toets ontwikkeld die als variant van de OSCE beschouwd kon worden (Williams, 1987; Stillman, 1989). Deze toets werd de Standardized Patient-Based Test (SP-based test) genoemd. Evenals bij de OSCE is hier sprake van een examen waarbij de kandidaat diverse opdrachten krijgt, die vervolgens uitgevoerd moeten worden. Ook dit is een stationsexamen waarbij de kandidaat bij sommige stations geobserveerd en beoordeeld wordt met behulp van gestandaardiseerde criterialijsten en in andere stations alleen schriftelijke vragen moet beantwoorden.

Toch zijn er ook verschillen. Het belangrijkste verschil betreft het inhoudelijke domein waarover getoetst wordt binnen één station. Binnen een SP-based test is dit domein veelal groter dan bij een OSCE. Gaat het bij een OSCE vaak om kleine, vaak van elkaar losstaande eenheden van onderzoek of kennis dat getoetst wordt, bij SP-based testen is er meer sprake van integrale toetsing van kennis, vaardigheden, attitude en medisch denken en handelen. Deze integrale benadering leidt over het algemeen tot langere totale toetstijden per station (15-30 minuten) en meestal tot langere toetstijden (2-6 uur). Dit is een tweede verschil met de OSCE. Een ander belangrijk verschil betreft de achtergrond van de beoordelaars. De beoordelaars zijn in tegenstelling tot de OSCE vaak simulatiepatiënten, die specifiek voor deze taak getraind zijn. Simulatiepatiënten vervullen dus bij dergelijke toetsen een dubbelrol, enerzijds als patiënt en anderzijds als beoordelaar. Men heeft daarvoor gekozen vanwege praktische redenen. In het algemeen zijn er niet genoeg stafleden (docenten) beschikbaar om studenten te observeren bij patientbased testen. Bovendien zouden simulatiepatiënten goedkoper zijn, in de meeste gevallen goed te trainen zijn (Tamblyn et al., 1991), in staat zijn dezelfde rol gedurende langere tijd op vergelijkbare wijze te spelen 
(Colliver et al., 1991) en betrouwbaar kunnen beoordelen (Vu et al., 1992).

Tabel 2: Voorbeeld van onderwerpen bij een Standardized Patient-Based Test aan de Universiteit van Southern Illinois (6e studiejaar)t.

\author{
pijn op de borst \\ gewichtsverlies \\ intermitterende koorts \\ depressie \\ hoofdpijn met buikpijn \\ brandend maagzuur \\ een kind verdacht van ontwikkelingsstoornissen \\ geelzucht \\ pijn in de buik \\ het acuut zieke kind \\ hypertensie \\ buiktrauma \\ keelpijn
}

${ }^{1}$ Duur ongeveer 20 minuten per station, vaak aangevuld met theoretische vragen waarvoor ook gemiddeld twintig minuten tijd beschikbaar is.

Bij een SP-based test zijn de criteria op de criterialijsten meestal globaler geformuleerd dan bij de meeste OSCE's. Dit geldt in het bijzonder daar waar het de technische uitvoering van de vaardigheid betreft. De gebruikte criterialijsten hebben dan ook niet alleen de vorm van een checklijst, maar geven voor een deel ook kwalitatieve oordelen over studenten, door middel van rating-scales.

Tabel 2 geeft voorbeelden van onderwerpen die in een dergelijke test aan de orde komen.

\title{
Psychometrische eigenschappen van station-examens
}

Zoals reeds in het begin van dit hoofdstuk is gesteld, was de gepercipieerde subjectiviteit van de klinische examens één van de redenen voor het ontwikkelen van OSCE's. Nu stationsexamens haast niet meer weg te denken zijn als onderdeel van het artsexamen lijkt de vraag gerechtvaardigd of de nieuw ontwikkelde examens in staat zijn de student 
objectiever te beoordelen dan vroeger. Dit heeft geleid tot een groot aantal onderzoeksvragen met betrekking tot aspecten van betrouwbaarheid. Nagegaan is welke elementen binnen een observatietoets een betrouwbare meting negatief zouden beïnvloeden. Verschillende foutenbronnen zijn daarbij in beschouwing genomen. Genoemd kunnen worden: verschillen in score van één observator, verschillen tussen observatoren, verschillen tussen simulatiepatiënten (proefpersonen), verschillen tussen de onderwerpen van de stations, verschillen in de vormgeving van de diverse stations. Over een aantal van de genoemde foutenbronnen zijn gegevens beschikbaar. Hiervan wordt in de volgende paragrafen verslag gedaan.

\section{Meetfouten in het beoordelingsproces (intrabeoordelaarsbetrouwbaar- heid)}

Aangezien deze vorm van betrouwbaarheid van ondergeschikte belang is voor de totale toetsbetrouwbaarheid, wordt hier verder niet op ingegaan.

\section{Meetfouten in het beoordelingsproces (interbeoordelaarsbetrouwbaar- heid)}

Bij de beoordeling van studenten blijkt dat de interbeoordelaarsbetrouwbaarheid zich op een acceptabel niveau bevindt. Intraclass-correlaties variëren tussen .70 en .80 voor de fysisch diagnostische en interviewvaardigheden (Newble \& Swanson, 1988; Van der Vleuten, 1989-C). In het algemeen wordt een hogere interbeoordelaarsbetrouwbaarheid behaald bij een checklijst in vergelijking met rating scales (Van der Vleuten \& Swanson, 1990). Dit lijkt logisch aangezien een checklijst vraagt om objectieve oordelen en een rating scale om subjectieve oordelen, meestal met inbegrip van kwalitatieve wegingen.

\section{Meeffouten door verschillen tussen simulatiepatiënten}

Een zorgvuldige training kan eventuele verschillen tussen simulatiepatiënten die dezelfde rol spelen aanzienlijk verkleinen. Stillman \& Swanson (1989) trekken echter wel de conclusie dat wanneer grotere aantallen studenten getoetst moeten worden, zoals bij landelijke examens het haast onmogelijk is de grote aantallen simulatiepatiënten die hiervoor nodig zijn intensief genoeg te trainen.

Ook Tamblyn (1991) komt tot de conclusie dat er soms substantiële verschillen tussen simulatiepatiënten kunnen optreden. De beschreven verschillen kunnen optreden ondanks dezelfde trainingscondities. De verschillen blijken enerzijds te ontstaan door verschillen in het 
verstrekken van spontane informatie aan de student, anderzijds door verschillen bij de presentatie van gegevens van het lichamelijk onderzoek en in affectieve componenten bij de presentatie van de klacht. Het bleek echter, dat simulatiepatiënten die systematisch gegevens verkeerd weergaven of vergaten, de student soepeler beoordeelden dan de simulatiepatiënten die hun rol wel goed speelden. Het netto effect was derhalve dat verschillen in het spelen van de rol door de verschillende simulatiepatiënten weinig tot geen effect had op de uiteindelijke beoordeling van de student.

Van der Vleuten \& Swanson (1990) signaleren tegenstrijdige bevindingen met betrekking tot verschillen tussen simulatiepatiënten die dezelfde rol spelen. Zij stellen echter ook vast dat deze verschillen op het totale toetsniveau uitmiddelen. Dit geldt overigens alleen wanneer er voldoende stations in de toets zitten, hetgeen bij de meeste stationsexamens niet het geval is (tabel 3).

\section{Meetfouten op stationsniveau}

De inhoudsspecificiteit blijkt een zeer grote variantiebron te zijn binnen station-examens. Inhoudsspecificiteit wil zeggen dat een score van een student op één bepaald station (patiëntenprobleem of casus) slechts in beperkte mate voorspellend is voor een score van diezelfde student op een andere casus (Swanson, 1987).

Om het effect van de inhoudsspecificiteit zo gering mogelijk te laten zijn en dus voor het verkrijgen van betrouwbare uitslagen op het totale toetsniveau (hierbij wordt vaak een willekeurige grens aangehouden van .80 als betrouwbaarheidscoëfficiënt) moeten er derhalve veel stations worden aangeboden. Dit kan alleen bereikt worden door langdurig te toetsen (Swanson, 1987; Van der Vleuten \& Swanson, 1990). Men moet dan denken aan een gemiddelde toetsduur van minimaal vier uur. Het verband tussen toetsbetrouwbaarheid en toetstijd is weergegeven in tabel 3.

Het probleem van de casusspecificiteit varieert echter per inhoudelijk domein. Voor communicatieve vaardigheden liet Van Thiel et al. (1992) zien dat niet veel stations noodzakelijk zijn. Zij bereikten reeds een acceptabele betrouwbaarheid (generaliseerbaarheidscoëfficiënt groter dan .80) bij 3-4 stations en ongeveer één uur toetstijd afhankelijk van het aantal observatoren. 
Tabel 3: Reproduceerbaarheid van scores van SP-based testen afhankelijk van de duur van de test (Van der Vleuten \& Swanson, 1990).

\begin{tabular}{|c|c|c|c|c|c|c|c|c|}
\hline \multirow[b]{2}{*}{ Studie } & \multicolumn{7}{|c|}{ Duur van de test (in uren) } & \multirow{2}{*}{$\begin{array}{c}\text { Gemiddelde } \\
\text { Stations- } \\
\text { lengte } \\
\text { in minuten }\end{array}$} \\
\hline & 1 & 2 & 3 & 4 & 6 & 8 & 12 & \\
\hline 1 & 0.65 & 0.79 & $0.85^{1}$ & 0.88 & 0.92 & 0.94 & 0.96 & 6 \\
\hline $2^{2}$ & 0.19 & 0.31 & 0.41 & 0.48 & 0.58 & 0.68 & $0.73^{1}$ & 40 \\
\hline 3 & $0.51^{1}$ & 0.68 & 0.76 & 0.81 & 0.86 & 0.89 & 0.93 & 20 \\
\hline 4 & $0.53^{1}$ & 0.67 & 0.77 & 0.82 & 0.87 & 0.90 & 0.93 & 15 \\
\hline 5 & $0.43^{\mathrm{t}}$ & 0.60 & 0.69 & 0.75 & 0.82 & 0.86 & 0.90 & 6 \\
\hline $6^{2}$ & 0.24 & 0.38 & $0.49^{1}$ & 0.56 & 0.66 & 0.72 & 0.79 & 10 \\
\hline $7^{2}$ & 0.19 & 0.32 & $0.41^{1}$ & 0.48 & 0.58 & 0.65 & 0.74 & 10 \\
\hline $8^{2}$ & 0.31 & $0.47^{1}$ & 0.57 & 0.64 & 0.73 & 0.78 & 0.84 & 10 \\
\hline 9 & 0.59 & 0.74 & $0.81^{1}$ & 0.85 & 0.90 & 0.92 & 0.94 & 30 \\
\hline 10 & 0.50 & $0.67^{1}$ & 0.75 & 0.80 & 0.86 & 0.89 & 0.92 & 10 \\
\hline 11 & 0.34 & 0.51 & 0.61 & $0.67^{1}$ & 0.76 & 0.80 & 0.86 & 15 \\
\hline 12 & 0.53 & 0.69 & 0.77 & $0.82^{1}$ & 0.87 & 0.90 & 0.93 & 20 \\
\hline $13^{3}$ & 0.46 & $0.63^{1}$ & 0.72 & 0.78 & 0.84 & 0.87 & 0.91 & 15 \\
\hline
\end{tabular}

Studie

1 Cohen et al., 1987

2 Colliver et al., 1989

3 Conn \& Cody, under editorial review

4 Grava-Gubins et al., 1987

5 Newble \& Swanson, 1988

6 Petrusa et al., 1986

De duur van de test is afgerond op hele uren

Inclusief schriftelijke stations

Hierbij zijn alleen resultaten van jaar 5 en jaar 6 genomen
7 Petrusa et al., 1987-A

8 Petrusa, 1988

9 Stillman et al., 1986

10 Stillman et al., 1987

11 Stillman et al., 1990

12 Templeton et al., 1978

13 Van der Vleuten et al., 1988-A

Het toevoegen van schriftelijk te beantwoorden vragen gekoppeld aan de te doorlopen stations, wat zowel bij de OSCE als bij de SP-based test gebeurt, heeft eerder een verlagend dan een verhogend effect op de totale toetsbetrouwbaarheid (Van der Vleuten \& Swanson, 1990). Dit is deels te verklaren doordat schriftelijke vragen bij stationsexamens meestal gerelateerd zijn aan één of meerdere voorafgaande stations zodat binnen een vastgestelde toetstijd inhoudelijk minder diverse onderwerpen aan bod kunnen komen, met een verlagend effect op de totale toetsbetrouwbaarheid. Voor zover schriftelijke stations niet gerelateerd zijn aan voorafgaande casuïstiek draagt het bij tot verbreding van het totale 
toetsdomein. Desalniettemin leidt het niet tot een substantiële verhoging van de totale toetsbetrouwbaarheid.

Betrouwbaarheden gerapporteerd in de literatuur gaan doorgaans uit van een normgeoriënteerd perspectief. Dat wil zeggen dat de relatieve posities van studenten ten opzichte van elkaar worden vastgesteld. Een uitslag van een student heeft in zo'n geval dus alleen betekenis in relatie tot uitslagen van andere studenten. Bijvoorbeeld een bepaalde student behoort tot de groep die $25 \%$ van de hoogste scores behaald. Van belang kan echter zijn dat niet alleen de relatieve posities van studenten ten opzichte van elkaar bepaald worden maar ook het absolute scoreniveau, vooral waar het gaat om het vaststellen van een bepaald competentieniveau aan het eind van een opleiding. Deze benadering stelt derhalve hogere eisen aan de betrouwbaarheid. Dit is een benadering vanuit domeingericht perspectief. Van der Vleuten en Swanson (1990) constateren dan ook dat deze benadering gepaard gaat met een substantiële verlaging van de betrouwbaarheid. Alleen bij hele lange toetsen ( 8 uur) is het verschil tussen een norm- en domeingerichte benadering klein. Dergelijke toetslengtes komen echter in de praktijk nauwelijks voor.

Naast de norm- en domeingerichte benadering is de betrouwbaarheid van zak/slaag beslissingen van studenten van groot belang. Deze betrouwbaarheid is afhankelijk van de cesuur. Naarmate de afstand van de studentscores tot de cesuur groter is zal de betrouwbaarheid van de beslissing toenemen (Van der Vleuten \& Van Luijk, 1988-B). Dit heeft als praktische consequentie dat in die gevallen volstaan kan worden met een korter stationsexamen.

\section{Validiteit}

Athankelijk hoe scores van een test geïnterpreteerd kunnen worden zijn verschillende soorten validiteit te onderscheiden. Tot nu toc hebben de meeste studies zich gericht op constructvaliditeit, concurrente/divergente validiteit en inhoudsvaliditeit. In de volgende paragrafen worden in het kort de bevindingen met betrekking tot de verschillende validiteitsstudies weergegeven. 


\section{Constructvaliditeit}

Constructvaliditeit is het op basis van theoretische overwegingen geven van een empirische onderbouwing aan een meetinstrument. In de praktijk wordt de constructvaliditeit vaak bepaald door het aantonen van groepsverschillen. Eerstejaars studenten zouden bijvoorbeeld op een toets voor vierdejaars studenten een lagere score moeten behalen dan de vierdejaars zelf. De schaarse onderzoeken die gedaan zijn (Stillman et al., 1982; Petrusa et al., 1987 B; Klass et al., 1990;) geven aan dat er inderdaad onderscheid te maken valt tussen niveaugroepen. Erg overtuigend is dit niet. Zo weet men bijvoorbeeld niet bij stationsexamens welke grootte-orde van verschillen men kan verwachten tussen de verschillende niveaugroepen. Er bestaat geen "gouden standaard". Een andere indicatie met betrekking tot constructvaliditeit betreffen gegevens met betrekking tot concurrente en divergente validiteit. Dit komt in de volgende paragraaf aan de orde.

\section{Concurrente/Divergente validiteit}

Bij concurrente validiteit wordt nagegaan in hoeverre meetinstrumenten, die hetzelfde beogen te meten ook dezelfde uitkomsten laten zien. Bij divergente validiteit wordt nagegaan in hoeverre bij meetinstrumenten die verschillende inhoudsgebieden meten, de resultaten inderdaad verschillen. Dergelijke studies zijn gebaseerd op correlationele verbanden tussen meetinstrumenten. Studies naar concurrente en divergente validiteit zijn theoretisch moeilijk te interpreteren.

Er worden zowel positieve als negatieve correlaties gevonden met meetinstrumenten gericht op andere dan wel vergelijkbare inhoudsgebieden.

De relaties tussen stationsexamens en kennistoetsen vertonen zeer wisselende correlaties (Van der Vleuten \& Swanson, 1990). Correlaties met andere maten voor klinisch functioneren van de studenten, bijvoorbeeld stagebeoordelingen laten een matig positief verband zien (Vu, 1992). De wisselende uitkomsten worden mede verklaard doordat stationsexamens over het algemeen zulke lage betrouwbaarheidscoëfficiënten hebben (Van der Vleuten \& Swanson, 1990), dat correlationele verbanden slechte schatters zijn van werkelijke relaties.

\section{Inhoudsvaliditeit}

Inhoudsvaliditeit is een belangrijke vorm van validiteit (Ebel, 1965; Kane, 1982). Ebel (1965) geeft aan dat een goede inhoudsvaliditeit 
bereikt wordt door een duidelijke omschrijving van essentiële elementen van het vakgebied, waar vervolgens bij toetsing een representatieve steekproef uit genomen moet worden. Wanneer een beroepsgroep de inhoud van een toets niet kan onderschrijven, verliest het instrument zijn betekenis. Het omgekeerde is echter niet altijd waar. Wanneer een toets als inhoudelijk zeer relevant wordt gezien wil dat nog niet zeggen dat daarmee het meetinstrument de toets der kritiek kan doorstaan. Inhoudsvaliditeit wordt meestal vastgesteld door de inhoud van het vakgebied te vergelijken met de inhoud van de toets. Deze beoordeling geschiedt meestal door ervaren beroepskrachten. Omdat de taken in een stationsexamen in het algemeen dicht tegen de praktijk aanliggen is de inhoudsvaliditeit één van de sterke punten van een dergelijk examen, zeker in vergelijking met schriftelijke examens (Newble, 1988).

Desalniettemin is er vaak kritiek op de OSCE omdat vaardigheden daar min of meer los van de klinische context worden getoetst (Harden \& Gleeson, 1979).

Het komt echter zelden voor dat een verzameling van taken in een toets representatief is voor het gehele te meten domein. Het feit dat de meeste stationsexamens het "domein" niet dekken blijkt uit de lage generaliseerbaarheidscoëfficiënten. Zoals eerder aangegeven blijkt dat de betrouwbaarheid veel lagere waarden bereikt dan de algemeen gewenste waarde van .80 (Van der Vleuten \& Swanson, 1990).

\section{Predictieve validiteit}

In de literatuur zijn veel studies beschreven over de predictieve validiteit van kennistoetsen binnen de medische opleiding. Dit betreft veelal studies die betrekking hebben op de relatie tussen cijfers behaald op de middelbare school of op een toelatingstest (Medical College Admission Test - MCAT) met examens (meestal schriftelijk) of beoordelingen binnen de medische studie (Mitchell, 1990; El-Mouzan, 1992; Rosenfeld et al., 1992; Hall et al., 1992.)

Veelal laten deze studies dezelfde resultaten zien. Er bestaan over het algemeen significante, maar geen hoge correlaties tussen middelbare schoolcijfers van de natuurwetenschappelijke vakken, de toelatingstesten tot de faculteit en studieprestaties in de medische studie. Correlationele verbanden tussen indicatoren uit de medische studie en vervolgstudies laten zeer wisselende correlaties (.10 tot .71) zien (Markert, 1993; Gonella et al., 1993).

Voor wat betreft de stationsexamens lijken de correlaties tussen schoolcijfers en toelatingstesten enerzijds met SP-based examens laag 
(Swanson et al., 1992). Er zijn tot nu toe vrijwel geen studies verricht die specifiek de predictieve validiteit van stationsexamens hebben nagegaan. Alleen Vu (1993) geeft aan dat Standardized Patient-based testen een goede indicator zijn voor het succesvol doorlopen van de vervolgopleidingen.

Andere verstorende factoren op de validiteit

In dit hoofdstuk blijkt dat er bij de stations-examens verschillen bestaan ten aanzien van de vormgeving binnen en tussen de stations en de operationalisatie van items. Hierbij kan gedacht worden aan verschillen in score-categorieën tot aan verschillen in gedetailleerdheid van items. De invloed hiervan op de uitkomsten van studenten is veelal onbekend. Dit kunnen verstorende variabelen zijn die van invloed zijn op die betreffende meting. Dit kan zich vervolgens vertalen in een verlaagde betrouwbaarheid en zal dientengevolge ook de validiteit aantasten. Kane (1982) vraagt zich met name af in hoeverre de operationalisatie van competentie door middel van uitgesplitste items binnen stationsexamens van invloed is op de validiteit. Een kritische kijk naar de vormgeving en operationalisatie van items binnen stations heeft in een enkel geval al tot aanpassingen van SP-based examens geleid (Shatzer, et al., 1992; Perkowski-Rogers, 1992)

Een andere verstorende factor op de validiteit betreft de invloed van OSCE's en SP-based toetsen op het studiegedrag van studenten (Newble \& Jäger, 1983; Newble, 1988). Studenten proberen zich op de meest efficiënte manier voor dergelijke examens voor te bereiden. Dit leidt tot ongewenste effecten, bijvoorbeeld het uit het hoofd leren van criterialijsten vlak voor een toets (Van Luijk et al., 1990). Hierdoor kan het voorkomen dat studenten in plaats van het tonen van de beheersing van een specifieke vaardigheid alleen benoemen wat ze willen gaan doen en teksten van criterialijsten gaan reproduceren (zie ook hoofdstuk 4). 


\section{Samenvatting en conclusies}

Uit de bovenstaande beschrijving zal het duidelijk zijn dat er qua doelstelling nauwelijks verschillen bestaan tussen de verschillende typen stationsexamens.

Zowel bij de OSCE als de SP-based testen wordt de inhoud van de toets in eerste instantie bepaald door de doelstelling medische competentie te toetsen bij studenten die zich in de eindfase van de studie bevinden of bij arts-assistenten in hun vervolgopleiding.

Daar waar de toetsen dezelfde doelstelling hebben, zijn ze in het algemeen ook inhoudelijk vergelijkbaar met betrekking tot de aangeboden casuïstiek.

Alle stationsexamens beschouwen kennis als een belangrijk te toetsen element binnen het examen. Uit dit hoofdstuk blijkt dat kennistoetsing tot de helft van de beschikbare toetstijd kan opeisen.

Ten aanzien van de vormgeving van stations bestaan er wel verschillen tussen de stationsexamens onderling. In het algemeen zijn er grote verschillen in de duur van de verschillende stations variërend tussen de 5 en 40 minuten. Bij deze laatste soort stations is wel vaak 20 minuten kennistoetsing inbegrepen.

Er zijn ook verschillen in de vormgeving van de items op een criterialijst bij de diverse toetsen. Soms worden de vaardigheden zeer gedetailleerd getoetst soms op een meer globale wijze. Daarnaast wordt vooral bij OSCE's en in mindere mate bij SP-based testen -naast het meten van kennis- getoetst op de procedure van de vaardigheid (worden bepaalde handelingen verricht en gebeurt dat in de goede volgorde).

Het wegen van items wordt bij alle stationsexamens in min of meer bescheiden mate toegepast. Wel komen er zeer gedifferentieerde wegingen voor tot op tienden van decimalen.

Bij stationsexamens kunnen simulatiepatiënten twee functies vervullen. Enerzijds worden simulatiepatiënten als "echte" simulatiepatiënt ingezet, anderzijds worden simulatiepatiënten ingezet als beoordelaar van studenten. Met name bij PB-based testen vervullen simulatiepatiënten beide soorten rollen.

De gegevens die beschreven zijn ten aanzien van de betrouwbaarheid en validiteit gelden voor alle soorten stationsexamens. Hieruit blijkt dat verschillen tussen observatoren (interbeoordelaarsbetrouwbaarheid) geen belangrijke verstorende variabele is op de totale toetsbetrouwbaarheid. Wel relevant met betrekking tot de totale toetsbetrouwbaarheid is de 
inhoudsspecificiteit van de stations. Het adequaat doorlopen van het ene station zegt weinig over het adequaat doorlopen van een volgend station. Gezien het feit dat stationsexamens de werkelijkheid dicht kunnen benaderen, is de inhoudsvaliditeit van dergelijke toetsen over het algemeen hoog. Onderzoek naar andere vormen van validiteit is tot op heden nog onvoldoende aan bod gekomen. Nader onderzoek op dit terrein is nodig. 


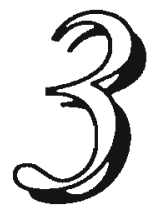

\section{HET EVALUATIESYSTEEM EN VAARDIGHEIDSTOETSING BINNEN HET MEDISCH CURRICULUM}

\section{Inleiding}

Dit hoofdstuk geeft eerst een globale beschrijving van de achtergronden van alle (formele) evaluatie activiteiten binnen het problecmgestuurd onderwijs aan de Faculteit der Geneeskunde van de Rijksuniversiteit Limburg. Tevens wordt ingegaan op de verankering van deze activiteiten binnen het Examenreglement en de Regels en Richtlijnen. Deze beschrijving dient als context om de plaats van de vaardigheidstoets binnen het geheel van evaluatie activiteiten te kunnen beoordelen. Vervolgens wordt gedetailleerd ingegaan op de ontstaanswijze, vormgeving en ontwikkeling van één van de genoemde evaluatieinstrumenten, de vaardigheidstoets. Gegevens van de vaardigheidstoets worden vergeleken met de beschikbare informatie van de OSCE en de SP-based test (hoofdstuk 2).

\section{Toetsing in probleemgestuurd onderwijs}

Een belangrijk uitgangspunt bij toetsing moet zijn dat de wijze waarop de evaluatie plaatsvindt overeenkomt met de uitgangspunten en de inhoud van het gegeven onderwijs. Het onderwijs binnen de Faculteit der 
Geneeskunde is probleemgestuurd en gebaseerd op enkele van de volgende principes.

Op de eerste plaats dient het onderwijs zo dicht mogelijk aan te sluiten bij de praktijk van de beroepsbeoefenaar. Met andere woorden klachten en problemen die binnen de gezondheidszorg voorkomen dienen als startpunt voor het leren van de student. Vanuit de klachten en problemen wordt kennis (en vaardigheden) verkregen over diverse disciplines waarbij tevens de samenhang tussen de diverse disciplines duidelijk wordt. De monodisciplinaire benadering zoals die vaak binnen traditionele medische opleidingen vorm heeft gekregen wordt vervangen door een geïntegreerde benadering.

Een andere consequentie van het principe dat onderwijs zo goed mogelijk moet aansluiten op datgene wat later van de beroepsbeoefenaar verwacht wordt, is dat er binnen het onderwijs veel tijd ingeruimd moet worden voor praktijkcontacten en de voorbereiding daarop. Vandaar dat studenten binnen het curriculum optimaal de mogelijkheid hebben zich voor te bereiden op de praktijk door middel van een groot aanbod aan vaardigheidstrainingen en korte stages op verschillende plekken binnen de gezondheidszorg.

Een volgend uitgangspunt is dat studenten zelf voor een groot deel verantwoordelijk zijn voor hun eigen leerproces. Immers na de studie zullen studenten in hun beroep ook deze verantwoordelijkheid moeten bezitten. Dit houdt in dat de nadruk in de vormgeving van het onderwijs niet ligt op een groot aantal verplichte geprogrammeerde onderwijsactiviteiten, maar op een beperkt aantal verplichte activiteiten met veel ruimte voor zelfstudie en onderwijs op "aanvraag". Tot het geringe aantal verplichte activiteiten behoort het actief participeren in onderwijsgroepen. Maar ook binnen de onderwijsgroep speelt de eigen verantwoordelijkheid voor het leren van de studenten een belangrijke rol. Studenten formuleren aan de hand van de aangeboden problemen in het blokboek hun eigen leerdoelen op basis van het inventariseren van kennis binnen de groep (Moust et al., 1989). Vervolgens wordt aan de hand van de leerdoelen de leerstof bestudeerd en de volgende bijeenkomst worden de resultaten van de studie binnen de onderwijsgroep besproken. Hierbij dienen studenten terug te rapporteren, kritisch te zijn met betrekking tot de verstrekte informatie en eventuele nieuwe leerdoelen te formuleren.

Uit bovenstaande beschrijving blijkt tevens dat de verantwoordelijkheid voor het eigen leren sterk gekoppeld is aan een actieve participatie en 
inzet van de student. De kleinschaligheid van het onderwijs ondersteunt en stimuleert een dergelijke actieve inzet.

Gelet op de uitgangspunten van het probleemgestuurd onderwijs dient het evaluatiesysteem ondermeer de volgende kenmerken te bezitten:

- er wordt niet per discipline getoetst, maar disciplineoverstijgend (integratie)

- er wordt getoetst aan de hand van problemen (probleem-oriëntatie)

- individuele leerwegen van studenten worden beloond (actieve studiehouding)

- toetsing dient niet alleen gericht te zijn op kennis maar ook op de praktijk, dat wil zeggen op vaardigheden, medisch denken en handelen en attitude (praktijk oriëntatie).

Naast bovenstaande punten dient een evaluatiesysteem ook te voldoen aan een aantal algemene onderwijskundige principes zoals:

- het -waar mogelijk- scheiden van de rol van docent en beoordelaar

- toetsing dient een continue activiteit te zijn

- toetsen moeten informatief zijn voor studenten, cq als leermiddel gebruikt kunnen worden

- toetsen dienen zo efficiënt mogelijk te worden afgenomen

- het bewaken van de kwaliteit van de toetsing (betrouwbaarheid, validiteit).

Een uitgebreid overzicht van alle evaluatie activiteiten en achtergronden kan men vinden in Van der Vleuten \& Verwijnen (1990). 


\section{De kwaliteitsbewaking van toetsen}

Om zowel de specifieke als de meer algemene onderwijskundige uitgangspunten van het evaluatiesysteem te bewaken heeft de faculteit een gecentraliseerd systeem van kwaliteitsbewaking van toetsen opgezet. Deze kwaliteitsbewaking heeft vorm gekregen binnen een project, het Project Evaluatie Studieresultaten (sedert 1 januari 1994; Evaluatie Project-Geneeskunde), waaraan personen uit verschillende disciplines en vakgroepen voor een belangrijk deel van hun werktijd in participeren. De kwaliteitsbewaking kan grofweg onderverdeeld worden in inhoudelijke/vormtechnische bewaking van toetsen, psychometrische bewaking van toetsen, onderzoek en ontwikkeling op het gebied van toetsing binnen probleemgestuurd onderwijs en advisering van belangrijke beleidsbepalende commissies zoals Examencommissie en Opleidingscommissie.

De inhoudelijke/vormtechnische bewaking van de toetsen wordt uitgevoerd door toetsbeoordelingscommissies, waarin een aantal leden van het Project Evaluatie Studieresultaten participeren. Een belangrijke tak van dergelijke commissies is het beoordelen van alle binnengekomen vragen of stations op een aantal inhoudelijke en vormtechnische punten. Ten aanzien van vormtechnische aspecten hebben de toetsbeoordelingscommissies het laatste woord. Hierbij kan men denken aan toetsvragen die op meerdere manieren zijn te interpreteren of, specifiek voor vaardigheidstoetsen, onduidelijk gestelde opdrachten, casuïstiek die niet aansluit bij de beoordelingslijst of een onvolledige rolomschrijving van de simulatiepatiënt.

De inhoudelijke eindverantwoordelijkheid blijft uitdrukkelijk voorbehouden aan de vakgroep.

Het Project Evaluatie Studieresultaten ondersteunt bovengenoemde commissies door relevante psychometrische gegevens van toetsen beschikbaar te stellen en eventuele (onderzoeks)vragen van commissies waar mogelijk te beantwoorden. 


\section{De vier verschillende te evalueren competentiedomeinen}

Binnen de Faculteit der Geneeskunde wordt het begrip medische competentie in een aantal aspecten onderscheiden, te weten kennis, vaardigheden, medisch denken en handelen en attitude. Op al deze aspecten wordt de student getoetst, zij het niet altijd in de vorm van formele examens.

\section{Kennis}

Kennis wordt gemeten door middel van de voortgangstoets en de bloktoets. De voortgangstoets is een schriftelijke toets op basisartsniveau waarin alle relevante disciplines vertegenwoordigd zijn. De voortgangstoets wordt afgenomen bij studenten van alle studiejaren. De toets bestaat uit stellingen die beantwoord kunnen worden met de opties juist/onjuist of het vraagteken. Dit laatste betekent dat studenten, indien ze de vraag niet weten, dit kunnen aangeven door middel van een vraagteken.

Gezien het feit dat de voortgangstoets een einddoelgerichte toets is komt deze toetsvorm tegemoet aan de wens vanuit het onderwijs individuele leerwegen van studenten te belonen.

Om de student regelmatig te confronteren met zijn voortgang in de studie, wordt de voortgangstoets vier maal per jaar in alle studiejaren afgenomen. Studenten uit alle studiejaren maken per afname dezelfde toets. Uiteraard kunnen eerstejaars studenten minder vragen beantwoorden dan ouderejaars studenten. Door de regelmatige afname en de vergelijkbaarheid tussen de verschillende voortgangstoetsen hoeven er geen aparte herkansingen te worden georganiseerd, hetgeen sterk bijdraagt tot de efficiëntie van deze toets.

De studenten krijgen uitgebreide en gedetailleerde informatie naar aanleiding van hun uitslag. Aan de hand hiervan kan de student op eenvoudige wijze inzicht verkrijgen over zijn zwakke en sterke punten.

Kennis wordt ook gemeten door middel van de bloktoets. In de meeste gevallen betekent dit dat er vijf tot zes bloktoetsen per jaar worden afgenomen. De inhoud van de bloktoets sluit aan op het direct daaraan voorafgaande onderwijsblok. Het voordeel van blokgebonden toetsing is dat er een directe koppeling bestaat tussen datgene wat in het blok wordt geleerd en de toetsinhoud. Toetsresultaten zijn derhalve makkelijker te vertalen naar inhoudelijke sterke of zwakke punten. Het nadeel is dat het leren binnen een blok gestuurd wordt door wat men op de toets kan 
verwachten. Dit kan ondermeer leiden tot het studeren in pieken op het laatste moment, waarvan de waarde voor het beklijven van de kennis op de langere termijn op zijn minst twijfelachtig is. Daarnaast kan afhankelijk van het gewicht van de bloktoets- blokgebonden toetsing een erg sturend en soms verstorend effect hebben op het leerproces in de onderwijsgroep. Daarom heeft de Faculteit der Geneeskunde resultaten op de voortgangstoets altijd zwaarder laten wegen bij de studievoortgang dan resultaten op de bloktoets.

Ook de bloktoets bestaat uit stellingen die met juist, onjuist of met een vraagteken kunnen worden beantwoord. Deze wijze van toetsing vindt alleen plaats in de eerste vier studiejaren. Bij de bloktoets worden dezelfde normeringsregels toegepast als bij de voortgangstoets. Ook de resultaten van de bloktoets worden gedetailleerd teruggerapporteerd.

\section{Vaardigheden}

Eén van de meetinstrumenten waarbij de wijze van toetsing sterk overeenkomt met een reële situatie in de praktijk van de gezondheidszorg is de vaardigheidstoets. De wijze waarop deze toets inhoudelijk is vormgegeven en wordt afgenomen wordt in de volgende paragrafen verder uitgebreid toegelicht.

Naast de vaardigheidstoets wordt kennis over vaardigheden ook regelmatig gemeten als een aparte categorie door middel van de bloktoets.

\section{Medisch denken en handelen}

Een ander meetinstrument waarbij de praktische situatie dicht bij de toetssituatie staat betreft de evaluatie van het medisch denken en handelen door middel van de stagebeoordelingen in het vijfde en zesde studiejaar. Hierbij wordt met name gekeken naar de geïntegreerde toepassing van kennis en vaardigheden op geleide van gezondheidsproblemen van patiënten in het ziekenhuis, bij de huisarts of binnen de geestelijke gezondheidszorg. In totaal zijn er tien stages die een student moet doorlopen. Elke stage wordt afgesloten met een stagebeoordeling.

\section{Attitude}

Er bestaan geen formele examens ten aanzien van het aspect attitude. Attitude onderwijs komt echter wel op verschillende plekken binnen het curriculum voor. 


\section{Verankering van de competentiedomeinen in het Examenreglement met de bijbehorende Regels en Richtlijnen}

De verschillende bovengenoemde competentiedomeinen kennis, vaardigheden, medisch denken en handelen en attitude zijn als zodanig apart verankerd binnen het Examenreglement en de Regels en Richtlijnen. Alleen die aspecten van het Examenreglement zullen genoemd worden die binnen het kader van dit proefschrift relevant zijn (hoofdstukken vier, acht en negen). Vandaar dat de plaats van het keuzeonderwijs binnen de examenregelingen niet wordt besproken. In dit hoofdstuk ligt de nadruk op de cesuren behorende bij de verschillende meetinstrumenten en de compensatiemogelijkheden bij onvoldoende resultaten. De nu volgende regelgeving is gebaseerd op de verschillende Examenreglementen en Regels en Richtlijnen tot en met het curriculumjaar 92/93, omdat de gegevens van dit proefschrift alleen betrekking hebben op die curriculumjaren. In het nieuwe Examenreglement met de bijbehorende Regels en Richtlijnen zijn de cesuren voor de verschillende meetinstrumenten dezelfde gebleven. De compensatieregelingen zijn fors aangepast en gelden nu niet meer.

Binnen het Examenreglement zoals dat gold tot en met het curriculum 1992/93 bestonden drie wettelijk vastgelegde examens gedurende de studie. Dit waren het propaedeuse- doctoraal- en artsexamen. Om voor deze examens te slagen moest ondermeer het eindoordeel over de vaardigheidstoets en voortgangstoets voldoende zijn, al dan niet na verkregen compensatie. Eveneens moesten alle stage-beoordelingen voldoende beoordeeld zijn.

\section{Voortgangstoets}

De normering van deze toets wordt bepaald aan de hand van het gemiddelde en de standaarddeviatie van de goed minus fout score van de beantwoorde vragen per jaargroep.

Een onvoldoende krijgt men indien de goed minus fout score van de ingevulde vragen lager is dan het gemiddelde min één standaarddeviatie van de jaargroep. Een voldoende kwalificatie krijgt men indien de goed minus fout score van de vragen groter is dan of gelijk aan het gemiddelde min een halve standaarddeviatie. Alle tussenliggende scores krijgen de kwalificatie twijfelachtig. 


\section{Compensatie}

Onvoldoende voortgangstoetskwalificaties konden op meerdere wijzen gecompenseerd worden. Enerzijds konden andere (volgende) voldoende kwalificaties op voortgangstoetsen voorafgaande onvoldoende kwalificaties compenseren. Anderzijds bestond de mogelijkheid dat een aantal voldoende kwalificaties op de bloktoets een onvoldoende of twijfelachtig resultaat op de voortgangstoets geheel of gedeeltelijk kon compenseren. Bloktoetsresultaten telden alleen in deze positieve zin mee voor de student.

\section{Bloktoets}

Hiervoor gelden exact dezelfde normeringsregels als voor de voortgangstoets.

\section{Compensatie}

Niet voldoende bloktoetsresultaten hoefden niet gecompenseerd te worden.

\section{Vaardigheidstoets}

Zak/slaaggrenzen worden eveneens bepaald aan de hand van een gemiddelde en standaarddeviatie van de bijbehorende jaargroep. De wijze waarop deze gegevens gehanteerd worden is op twee punten na identiek aan die van de voortgangstoets. Het eerste verschil heeft betrekking op het feit dat bij de normering van de vaardigheidstoets alleen wordt uitgegaan van de goedscore van items. Voor fouten wordt geen punt afgetrokken. Een tweede belangrijk verschil heeft betrekking op het feit dat naast de relatieve norm ook een absolute norm geldt. Is de individuele score van de student lager dan 55\% dan heeft de student altijd onvoldoende ongeacht het gemiddelde en de standaarddeviatie van de jaargroep. Het omgekeerde geldt voor individuele scores boven de $70 \%$. Hierbij heeft een student altijd de kwalificatie voldoende.

Individuele scores boven de zeventig procent komen in de praktijk vaak voor.

\section{Compensatie}

De compensatie bij de vaardigheidstoets bestond in feite alleen bij het doctoraalexamen. Een voldoende resultaat in het tweede en derde studiejaar op de vaardigheidstoets kon een twijfelachtige kwalificatie in het vierde studiejaar compenseren. In alle andere gevallen kon een nietvoldoende resultaat van de vaardigheidstoets voor de propaedeuse, het 
doctoraal- en artsexamen alleen gecompenseerd worden door een eenmalige herkansing van de vaardigheidstoets. Wanneer men hiervoor geen voldoende kwalificatie behaalde dan moest men geheel of gedeeltelijk het studiejaar herhalen.

\section{Medisch denken en handelen}

Ook alle tien stages moeten voldoende beoordeeld worden. Bij de meeste stages vindt de beoordeling mede plaats op basis van formele examens binnen de stage. Ook aspecten van attitude, weerspiegeld in het gedrag van de student gedurende de stage, kunnen in de beoordeling betrokken worden. De uiteindelijke beoordeling van de stage wordt weergegeven in een cijfer (1-10) en is opgebouwd uit deelbeoordelingen op het gebied van kennis, vaardigheden, attitude en medisch denken en handelen.

Tabel 1: $\quad$ Samenvatting van de belangrijkste kenmerken tussen voortgangstoets, vaardigheidstoets, bloktoets en stagebeoordelingen.

\begin{tabular}{|c|c|c|}
\hline & Voortgangstoets & Vaardigheidstoets \\
\hline Domein & Kennismeting & Vaardigheidsmeting \\
\hline Niveau & Eindtermen van de opleiding & Al het gegeven onderwijs \\
\hline Afname & Vier maal per jaar & Eénmaal per jaar \\
\hline Vorm & Schriftelijk & Observatie \\
\hline Antwoordcategorie & Goed/fout/vraagteken & Diverse mogelijkheden \\
\hline Normering & Relatieve norm & $\begin{array}{l}\text { Combinatie van relatieve en } \\
\text { absolute norm }\end{array}$ \\
\hline \multirow[t]{2}{*}{ Compensatie } & $\begin{array}{l}\text { Voldoende voortgangstoetsresultaten } \\
\text { en/of bloktoetsresultaten }\end{array}$ & $\begin{array}{l}\text { Volgende vaardigheidstoets } \\
\text { resultaten }\end{array}$ \\
\hline & Bloktoets & Stagebeoordelingen \\
\hline Domein & $\begin{array}{l}\text { Kennismeting } \\
\text { handelen }\end{array}$ & Medisch denken en \\
\hline Niveau & Eindtermen van het blok & Eindtermen van de stage \\
\hline Afname & Na ieder blok (4-7 keer per juar) & $\mathrm{Na}$ iedere stage (totaal 10 ) \\
\hline Vorm & Schriftelijk & Mondeling en schriftelijk \\
\hline Antwoordcategorie & Goed/fout/vraagteken, soms essay & Diverse mogelijkheden \\
\hline Normering & Relatieve norm & Diverse mogelijkheden \\
\hline Compensatie & $\begin{array}{l}\text { Onvoldoende resultaten hoeven niet } \\
\text { gecompenseerd te worden }\end{array}$ & $\begin{array}{l}\text { Herhaald examen en/of } \\
\text { herhalen stage (gedeeltelijk) }\end{array}$ \\
\hline
\end{tabular}




\section{Compensatie}

Er bestond geen compensatie tussen de stages of met andere competentiedomeinen. Meestal kon een student per stage éénmaal het examen herhalen. Werd dan opnieuw geen voldoende kwalificatie behaald dan moest de stage geheel of gedeeltelijk opnieuw worden doorlopen en afgesloten met een examen.

Tabel 1 geeft een overzicht van de belangrijkste verschillen en overeenkomsten tussen vaardigheidstoets, voortgangstoets, bloktoets en stagebeoordelingen.

\section{Het toetsen van (medische) vaardigheden aan de Rijksuniversiteit Limburg}

Binnen de Faculteit der Geneeskunde werden de eerste (experimentele) vaardigheidstoetsen in 1980 afgenomen en sedert 1982 vindt er een systematische toetsing plaats over de onderwezen vaardigheden voor alle studenten van alle jaargroepen. Een overzicht van alle vaardigheden die studenten geacht worden minimaal te beheersen als voorbereiding op de co-assistentschappen is te vinden in bijlage 2 .

Tot en met het curriculumjaar 91/92 werden gemiddeld 900 studenten per jaar getoetst (exclusief herkansingstoetsen), waarvoor zeven (ieder jaar één toets, zesdejaar twee toetsen) reguliere toetsen werden georganiseerd.

De totale toetsduur bedraagt als regel twee uur. Alleen voor het eerste ( 1,5 uur) en het vijfde jaar ( 1 uur) zijn uitzonderingen gemaakt. Sedert het curriculumjaar 92/93 wordt de vijfdejaars vaardigheidstoets niet meer afgenomen. Vanaf het curriculumjaar 93/94 is de vaardigheidstoets van het zesdejaar verlengd tot drie uur.

De inhoud van de vaardigheidstoets

Bij de start van de vaardigheidstoetsing heeft men zich met name laten inspireren door Harden (Harden \& Gleeson, 1979) die de OSCE had ontworpen en beschreven. De eerste vaardigheidstoetsstations waren korte stations (4,5 en 7,5 minuten) die sterk gericht waren op de procesmatige kant van de vaardigheid los van een bepaalde context. Zo 
werd een station bloeddrukmeten en een station lichaamsmetingen (meten van lengte en gewicht van een proefpersoon) afgenomen in het eerste basisartsexamen. Het onverkort toepassen van het model van de OSCE over alle studiejaren riep al snel weerstand op bij een groot deel van de observatoren en studenten (zie ook hoofdstuk 4). Een drietal bezwaren die met name betrekking hadden op de discrepantie tussen de toetssituatie en de praktijksituatie voor studenten in de hogere studiejaren werd vaak genoemd. Ten eerste vond men het toetsen van vaardigheden los van iedere (medische) context niet aansluiten bij de praktijk. Ten tweede miste men de integratie met andere competentie domeinen (kennis). Ten derde vond men dat de vaardigheden in vele gevallen te gedetailleerd getoetst werden (zie ook hoofdstuk 7).

Mede door deze kritiek ontstond het besef dat in de diverse studiejaren qua onderwijs verschillende doelen nagestreefd moeten worden die ook hun modelmatige vertaling zouden moeten vinden in de vaardigheidstoets. Vandaar dat in de loop der tijd de blauwdruk van de vaardigheidstoets meer ging aansluiten op en uiteindelijk volledig werd bepaald door het aangeboden vaardigheidsonderwijs (zie hoofdstuk 1). Dit betekent voor de huidige situatie dat in de eerste twee studiejaren de nadruk is komen te liggen op het gedetailleerd toetsen van de techniek en de systematiek van de handeling, voor wat betreft de motorische vaardigheid. Ten aanzien van sociale vaardigheden dient de student de basisvaardigheden op het gebied van de communicatie (bijvoorbeeld reflecteren van gevoelens, samenvatten) te beheersen. In het daarop volgende derde en vierde studiejaar wordt naast het meer globaal toetsen van de techniek en de systematiek ook de diagnostiek en bevindingen van de aangeboden casuïstiek in de beoordeling betrokken. Voor de sociale vaardigheden komen dan met name de complexe gespreksmodellen aan de orde (bijvoorbeeld het slecht nieuws gesprek). In de laatste twee studiejaren, waarbij de student actief participeert in de gezondheidszorg, staat tenslotte de integrale benadering van de klacht waarmee de patiënt komt centraal in het beoordelingsproces (spreekuur situatie). Hierbij vindt ook zoveel mogelijk een integratie tussen motorische en sociale vaardigheden plaats. In hoofdstuk 6 is te lezen in hoeverre men hierin geslaagd is.

Een en ander betekent dat in de hogere studiejaren steeds meer, voor wat betreft de inhoud van de toets, het amerikaanse model van de SP-based test wordt toegepast in tegenstelling tot het begin van de studie, waarbij de vaardigheidstoets, door de korte gerichte opdrachten in een beperkte 
tijd meer de inhoudelijke en vormtechnische kenmerken van een OSCE heeft.

Een overzicht van onderwerpen die bij de vaardigheidstoetsen van het vijfde of zesde studiejaar aan de orde zijn geweest zijn ter illustratie opgenomen in tabel 2.

Tabel 2: $\quad$ Overzicht van onderwerpen binnen verschillende vaardigheidstoetsen van de Rijksuniversiteit Limburg (5e en 6e studiejaar)'.

pijn in de scheenstreek

pijn in de rug en bovenkant van de bilstreek

onregelmatig bloedverlies

acute poststreptococcen glomerulonefritis bij een kind

trauma capitis

acute nierinsufficiëntie bij een kind

angina pectoris

haemoptoë

chronische pancreatitis

ulcus ventriculi

acute hoofdpijn

duizeligheid

beginnende zwangerschap

pijn in de schouder

${ }^{1}$ Het betreft hier stations die 20 of 30 minuten duren.

Voorbeelden van uitgewerkte stations gebruikt in de vaardigheidstoets uit het eerste (OSCE formaat) en laatste studiejaar (SP-Based test formaat) zijn te vinden in de bijlagen 3 en 4 .

In tegenstelling tot de OSCE en de SP-based toetsen, kent de vaardigheidstoets geen onderdelen die alleen maar schriftelijk hoeven te worden afgelegd. Dit vanuit de gedachte dat een schriftelijke toetsing gemakkelijker en goedkoper binnen een andere toetsvorm, kan plaatsvinden.

De vorm warin de vaardigheidstoets wordt afgenomen

Het aantal stations in de vaardigheidstoets varieert van 4 tot 10. De stationsduur wisselt van 10 tot 30 minuten. Binnen eén station kunnen meerdere opdrachten aan studenten worden uitgereikt.

Zoals reeds aangeduid bedraagt de totale toetsduur meestal twee uur. Om organisatorische redenen wordt de toets verspreid over twee dagen afgenomen. De ene dag de eerste helft van de toets (é́n uur) en de volgende dag de andere helft. In het algemeen worden 24 studenten per 
uur getoetst. Alle studenten in dat uur doorlopen dezelfde stations. Een dergelijke serie van stations wordt circuit genoemd. Om de twee uur wisselt het circuit ten aanzien van de inhoud van de stations, bijvoorbeeld speculumonderzoek in plaats van vaginaal toucher. Dit om de overdracht van informatie tussen studenten te voorkomen. Het domein waarbinnen getoetst wordt, in dit voorbeeld gynaecologie, blijft de hele dag echter wel hetzelfde. Op die manier ontstaan er paralleltoetsen voor diverse groepen studenten.

De afname van de toets geschiedt grotendeels op dezelfde manier als eerder omschreven voor de andere toetsen. Ook bij de vaardigheidstoets is er sprake van een stationsexamen, waarbij studenten worden geacht bij ieder station een bepaalde vaardigheid te demonstreren onder toeziend oog van een observator en eventueel een co-observator. Een belsignaal geeft aan dat de student naar een ander station moet gaan om vervolgens op een andere vaardigheid door een andere observator beoordeeld te worden. Na afloop van de toets wordt systematisch bij observatoren en studenten om een inhoudelijke, vormtechnische en organisatorische evaluatie van de toets gevraagd. In hoofdstuk vier kan men kennisnemen van de resultaten van deze evaluatie.

Een voorbeeld van een volledige vaardigheidstoets is te zien in de tabellen drie en vier. 
Tabel 3: $\quad$ Voorbeeld van instructies aan studenten van het eerste gedeelte van een vaardigheidstoets van het derde studiejaar (Eerste dag; één uur).

\section{Neurologisch onderzoek}

10 minuten

Doe een gericht onderzoek naar uitval van de volgende hersenzenuwen: $2,3,4$ en 6 . Vertel wat $U$ doet, waar $U$ op let en wat Uw bevindingen zijn.

\section{Onderzoek MondKeelholte}

10 minuten

Deze patiënt heeft een "brok"gevoel in de keel en soms wat pijn bij het slikken. De pijn straalt uit naar het rechter oor. Tevens is de neusademhaling bemoeilijkt. Verricht het $\mathrm{KNO}$ onderzoek dat $\mathrm{U}$ nodig acht.

\section{Oogheelkundig onderzoek}

10 minuten

Verricht fundoscopie bij het fantoom. Vertel wat $U$ doet, waar $U$ op let en wat Uw bevindingen zijn. Wijs uit de klaarliggende foto's het fundusbeeld van het fantoom aan.

\section{Abdomenonderzoek}

20 minuten

Deze patiënt ( $50 \mathrm{jr})$ klaagt over pijn in de buik. Neem een anamnese af (5-8 minuten) en doe een buikonderzoek uitgezonderd rectaal toucher. Vertel wat U doet, waar U op let en wat Uw bevindingen zijn. Aanvullende gegevens worden waar nodig door de observator verstrekt.

\section{De rol van de (co)observator}

De observatoren zijn in een groot aantal gevallen artsen (voornamelijk ten behoeve van het toetsen van fysisch diagnostische, therapeutische en laboratoriumvaardigheden) en/of personen met een gedragswetenschappelijke achtergrond (voornamelijk ten behoeve van het toetsen van sociale vaardigheden).

Soms wordt een student ook beoordeeld door een zogenaamde "coobservator". Deze persoon heeft tot taak onafhankelijk van de observator te komen tot een oordeel over de vaardigheid van de student. (Co)observatoren worden geworven per vakgroep. Afhankelijk van het te toetsen domein worden bepaalde vakgroepen meer of minder ingezet. 
Tabel 4: $\quad$ Voorbeeld van instructies aan studenten van het tweede gedeelte van een vaardigheidstoets van het derde studiejaar (Tweede dag; én uur).

\section{Onderzoek bewegingsapparaat}

20 minuten

Een patiënt bezoekt Uw spreekuur met de volgende klachten: Sinds twee jaar pijn in de rug, klachten zijn progressief maar worden met name de laatste twee maanden erger. Er zijn ook startklachten en klachten over ochtendstijfheid.

Voer nu het onderzoek van de rug uit en hetgeen $U$ belangrijk vindt voor $U w$ differentiaal diagnose, zijnde discopathie en $M$. Bechterew. Benoem alles wat $U$ doet (ook als U slechts kijkt) en geef van alles wat $U$ doet uw bevindingen.

\section{Laboratoriumvaardigheden}

\section{0 minuten}

Bij een 70-jarige subfebriele man is op grond van anamnese en fysisch-diagnostisch onderzoek mogelijk sprake van een luchtwegaandoening. Het aanvullend laboratoriumonderzoek bestaat uit een sputumonderzoek. Beoordeel het macroscopisch effect van het sputummonster. Beoordeel het grampreparaat van het sputummonster. Beoordeel de uitslag van het microscopisch onderzoek.

\section{Communicatie vaardigheden}

20 minuten

U loopt stage bij een huisarts en er komt een patiënt waarvan geen gegevens bekend zijn. Voer een geheel consult met deze patiënt, met uitzondering van eventueel noodzakelijk lichamelijk onderzoek. De uitkomsten van een dergelijk onderzoek kun je vragen aan de observator. Voer de volgende opdrachten uit: vraagverheldering, speciële anamnese, voorlichting en hulpaanbod.

\section{Thoraxonderzoek}

\section{0 minuten}

Verricht bij de proefpersoon de noodzakelijke inspectie ter beoordeling van de ventilatie/gaswisseling. Verricht bij deze patiënt de volledige percussie van de thorax mbt de longen. (N.B. hartgrenzen hoeven niet bepaald te worden). Benoem de percussietonen. Bepaal tevens de stemfremitus en bronchofonie. Benoem eventueel bepaalde grenzen anatomisch (in relatie tol oriëntatiepunten thorax).

Vertel wat $U$ doet, waar $U$ op let en wat Uw bevindingen zijn.

Elke (co)observator wordt geacht, voorafgaand aan de toets, een training (voorbespreking) te doorlopen die specifiek gericht is op het beoordelen van het station dat geobserveerd moet worden. Deze voorbespreking wordt geleid door de ontwerper van het station. Aangezien er in de meerderheid van de gevallen vanuit gegaan kan worden dat observatoren 
inhoudsdeskundig genoeg zijn, ligt het accent op meer procedure kwesties, zoals afspraken over welke informatie op welk moment aan een student gegeven moet worden. Een belangrijk aspect betreft ook het bespreken van de scoringscriteria. Niet zozeer de inhoud en de relevantie staan dan ter discussie maar veeleer de vraag hoe bepaalde criteria in bepaalde situaties moeten worden toegepast.

Soms wordt de vaardigheid voorgedaan, waarbij vervolgens de observatoren de vaardigheid met behulp van hun criterialijst kunnen scoren.

Tijdens de toets beoordeelt de observator de student aan de hand van een beoordelingslijst (zie volgende paragraaf), criterialijst genoemd. In principe treedt de observator zo min mogelijk sturend op wanneer de student zijn opdracht uitvoert. Dit om zo min mogelijk het denkproces en de systematiek van de student te verstoren. In sommige gevallen blijkt het echter nodig studenten juist een beetje op weg te helpen en worden zwijgzame observatoren als bijzonder onaangenaam ervaren. Over het algemeen is de observator gedurende de gehele toetsdag beschikbaar voor een bepaald toetsdomein. Dit betekent dat observatoren zes tot zeven uur per dag observeren. Men ervaart dit wel als erg zwaar, maar nog net haalbaar.

Wanneer de student de vaardigheid verricht heeft en er nog tijd over is, vindt een nabespreking plaats aan de hand van de criterialijst.

$\mathrm{Na}$ de toets kunnen observatoren commentaren op de inhoud, vormgeving en organisatie invullen op een enquêteformulier.

\section{De beoordelingslijst}

De observator heeft voor de beoordeling de beschikking over criterialijsten die over het algemeen voor de eerste jaargroepen gedetailleerd zijn. Dit sluit aan bij het gedetailleerde onderwijs in vaardigheden in die fase van de studie (hoofdstuk 1). Naarmate de toetsing echter meer gericht wordt op integratie van vaardigheden, beleid en diagnostiek zoals in de hoogste studiejaren, krijgen de lijsten een meer globaal karakter.

De beoordelingscategorieën waaruit een observator kan kiezen bestaan tot nu toe vrijwel altijd uit dezelfde drie of vierpuntsschalen te weten; goed uitgevoerd, (soms de categorie: matig uitgevoerd), slecht uitgevoerd en niet verricht of synoniemen hiervan zoals goed, fout en niet uitgevoerd. De waardering voor de diverse antwoordcategorieën bedraagt 1 (goed), 0 (fout of slecht) en 0 (niet verricht). Door het invoeren van globale oordelen neemt de behoefte om met meer beoordelingsca- 
tegorieën te werken toe. Incidenteel komen er nu ook 7-puntsschalen voor.

Binnen stations kunnen items gewogen worden. De belangrijkste overweging hierbij is dat constructeurs van toetsmateriaal en observatoren de criterialijst beter bij de praktijk vonden passen indien bepaalde handelingen en gedragingen zwaarder zouden tellen dan andere. Weging gebeurt in het algemeen voor items die te maken hebben met bevindingen of conclusies. Maar dit gebeurt niet systematisch bij alle casuïstiek. Er bestaat een maximum van zesmaal de oorspronkelijke itemwaarde, maar de weging komt in de praktijk zelden uit boven driemaal de oorspronkelijke itemwaarde. De totaalscore van het station wordt bepaald door het aantal behaalde punten te delen door het maximum aantal te behalen punten (maal 100).

\section{De rol van de simulatiepatiënt}

Afhankelijk van het soort opdracht dat de student moet verrichten wordt gebruik gemaakt van modellen (materialen waarop bepaalde onderzoeken kunnen worden aangeleerd zoals reanimatiepoppen of poppen voor inwendig gynaecologisch onderzoek), ongetrainde proefpersonen of simulatiepatiënten, die door middel van een specifieke training voorbereid zijn.

Simulatiepatiënten zijn personen die geselecteerd worden op basis van het kunnen instuderen en simuleren van een bepaalde ziekterol.

Voor iedere toets worden simulatiepatiënten getraind door de maker van het betreffende station. Simulatiepatiënten worden niet ingezet voor het beoordelen van studenten. Hieraan liggen verschillende redenen ten grondslag.

In eerste instantie heeft het niet inschakelen van simulatiepatiënten te maken met de gepercipieerde acceptabiliteit van de beoordeling. Het is niet acceptabel voor de faculteit en voor studenten dat getrainde leken bepalen of een student al dan niet het artsdiploma verkrijgt. Dat wordt beschouwd als een taak die voorbehouden moet zijn aan de docenten. Zeker gezien de consequenties die het zakken voor deze toets kan hebben voor de individuele student (zie hoofdstuk 3).

Een voordeel van de inzet van docenten als beoordelaar is dat van docenten een grote betrokkenheid mag worden verwacht ten aanzien van de toetsing. Docenten geven immers het onderwijs en krijgen door hun participatie binnen de toets feedback over het effect ervan. Tevens kunnen docenten gemakkelijker inhoudelijk commentaar geven op studenten, wat de feedbackwaarde van de toets verhoogt. 


\section{Verschillen en overeenkomsten tussen de vaardigheidstoets en andere stationsexamens}

De verschillen en overeenkomsten tussen de vaardigheidstoets en elders gebruikte stationsexamens (zie hoofdstuk 2) laten zich als volgt rubriceren.

\section{- Verschillen in doelstelling}

Een eerste verschil tussen de vaardigheidstoets en elders toegepaste stationsexamens heeft betrekking op de doelstelling van de toets. In het geval van de vaardigheidstoets worden, zoals reeds eerder aangegeven, verschillende doelen nagestreefd afhankelijk van de jaargroep. In het begin van de opleiding is de vaardigheidstoets meer gericht op het toetsen van de vaardigheid los van enige context met veel nadruk op de procedure en systematiek. Deze doelstelling verandert als de studenten aan het eind van de opleiding komen. Hierbij wordt de nadruk gelegd op het toetsen van vaardigheden binnen een duidelijke context.

Stationsexamens elders zijn gericht op het toetsen van medische competentie. Met andere woorden de doelstelling is veel breder dan bij de vaardigheidstoets.

\section{- Verschillen in inhoud}

Verschillen in doelstellingen leiden ook tot verschillen in inhoud tussen vaardigheidstoetsen hier en elders. Aangezien er binnen andere curricula, voor wat betreft de opleiding tot arts, vrijwel niet op vaardigheden getoetst wordt op andere momenten dan in de eindfase van de studie of bij de start van de klinische fase, ligt hier al een inhoudelijk verschil.

Gelet op het feit dat vaardigheidstoetsen goed moeten aansluiten op het probleemgestuurd onderwijs, bestaat de vaardigheidstoets inhoudelijk uit bijdragen van een groot aantal verschillende vakgroepen. Bij stationsexamens elders lijkt chirurgische en internistische problematiek wat pregnanter aanwezig, mede door het feit dat vakgroepen in sommige gevallen zelf stationsexamens organiseren.

Een belangrijk inhoudelijk verschil tussen de vaardigheidstoets en stationsexamens elders ligt in het toetsen van kennis binnen een stationsexamen. Bij de vaardigheidstoets wordt de kennis, conform de definitie (hoofdstuk 1) alleen binnen een station getoetst als deze 
direct gerelateerd is aan en relevant ten aanzien van het verrichte onderzoek én deze kennis niet op een meer efficiënte wijze getoetst kan worden. Het toetsen van kennis los van de casus is geen expliciet doel binnen de vaardigheidstoetsing.

\section{- Verschillen in vormgeving van de beoordelingscriteria}

De beoordelingscriteria zijn bij de vaardigheidstoets soms zeer verschillend met betrekking tot de mate van detaillering. In die gevallen waarbij de vaardigheidstoets gebruikt maakt van meer globale lijsten komen ze overeen met die van de OSCE of SP-based testen. In de eerste vier studiejaren zijn de beoordelingscriteria bij de vaardigheidstoets aanmerkelijk gedetailleerder dan bij andere stationsexamens.

\section{- Verschillen in beoordelingsschaal}

$\mathrm{Bij}$ de vaardigheidstoets wordt in de hogere studiejaren getracht een bepaald kwalitatief oordeel uit te spreken (zeer goed, goed, matig, slecht, zeer slecht) door middel van rating-scales. Bij de meeste andere stationsexamens wordt vaak volstaan met een controle of een student iets gedaan heeft of niet aan de hand van checklijsten, met name waar het fysisch-diagnostische handelingen betreft.

- Verschillen met betrekking tot de inzet van simulatiepatiënten Simulatiepatiënten binnen een vaardigheidstoets worden niet ingezet als beoordelaar van studenten, maar alleen als een patiënt die een ziekte simuleert. Met name bij PB-based testen kunnen simulatiepatiënten beide soorten rollen vervullen.

- Verschillen met betrekking tot de inzet van stafleden Hoewel stafleden in SP-based testen soms worden ingezet voor het heoordelen van fysisch diagnostische en sociale vaardigheden, blijkt het merendeel ingezet te worden om de kennisvragen, gerelateerd aan de stations, te corrigeren.

- Overeenkomstige psychometrische bevindingen met betrckking tot betrouwbaarheid en validitcit

De gegevens die beschikbaar zijn ten aanzien van de betrouwbaarheid en validiteit zijn in het algemeen geldend voor alle stationsexamens. Hierbij "gedraagt" de vaardigheidstoets zich niet anders dan de andere beschreven toetsen in dit hoofdstuk. Met andere woorden, ook voor 
de vaardigheidstoets geldt ten aanzien van de betrouwbaarheid dat de totale toetsbetrouwbaarheid een punt van zorg is (zie tabel 3, hoofdstuk 2). Dit is een gevolg van de reeds eerder beschreven (hoofdstuk 2) casusspecificiteit van de afzonderlijke stations. Daarentegen spelen verschillen tussen observatoren vanuit "betrouwbaarheidsperspectief' slechts een marginale rol.

Een ander punt van overeenkomst betreft de hoge inhoudsvaliditeit van dergelijke toetsen. Gelet op de wijze waarop de blauwdruk bij de vaardigheidstoets wordt samengesteld (hoofdstuk 3 ) en de oordelen over de relevantie van de stations (hoofdstuk 4) kan men ook bij de vaardigheidstoets spreken van een hoge mate van inhoudsvaliditeit. Ook op de overige aspecten van betrouwbaarheid en validiteit zijn geen duidelijke verschillen zichtbaar -voor zover aanwezig- tussen de vaardigheidstoets enerzijds en de OSCE en de SP-Based test anderzijds.

\section{Tot slot}

In dit hoofdstuk is veel aandacht besteed aan de plaats van de vaardigheidstoets ten opzichte van andere meetinstrumenten en de feitelijke uitwerking van de vaardigheidstoets in de praktijk. Niet vermeld is hoe de "consumenten" (studenten en docenten) van de vaardigheidstoets oordelen over de inhoudelijke en vormtechnische uitwerking van dit meetinstrument. Hierop wordt in het volgende hoofdstuk ingegaan. 


\section{4}

\section{ERVARINGEN MET VAARDIGHEIDS- TOETSEN: HET CONSUMENTENOORDEEL}

\section{Inleiding}

In dit hoofdstuk zullen gegevens besproken worden van enquêtes die na iedere reguliere vaardigheidstoets bij studenten en observatoren worden afgenomen. Deze gegevens hebben betrekking op opinies en ervaringen van docenten en studenten opgedaan met de vaardigheidstoets gedurende de afgelopen tien jaar. Hierbij wordt ingegaan -in aansluiting op hoofdstuk twee- op de inhoudsvaliditeit van de vaardigheidstoets. Tevens wordt aandacht besteed aan een aantal aspecten betreffende de voorbereiding, invulling en uitvoering van de rol van observatoren. Hoe adequaat is de voorbereiding van (co)observatoren, hoe wordt het werken met een checklijst ervaren, hoe duidelijk is de observatorrol voor observatoren zelf? Daarnaast wordt ingegaan op de vraag hoe studenten het functioneren van (co)observatoren op een aantal punten ervaren. Waar nodig wordt een aantal van de genoemde aspecten geplaatst binnen het kader van het Examenreglement en de Regels en Richtlijnen zoals die in hoofdstuk drie beschreven zijn.

Eveneens zal kort worden ingegaan de beleving van studenten van de vaardigheidstoets. 


\section{Methode}

\section{Instrumenten}

Vanaf het studiejaar 1982/83 zijn systematisch voor alle jaargroepen gegevens verzameld over de ervaringen van studenten en observatoren met betrekking tot de vaardigheidstoets. De vragen aan de studenten hebben betrekking op de organisatie, toetsonderdelen (stations), observatoren en simulatiepatiënten. De vragen gericht aan de observatoren betreffen de organisatie, training voor observatoren en criterialijsten. Daarnaast bestaat er voor beide groepen, zowel observatoren als studenten, de mogelijkheid om zelf aanvullende opmerkingen te maken in de daartoe vrijgehouden ruimte op de enquêtelijst. Met name studenten maken hier veel gebruik van.

Voor studenten bestaat de enquête uit 15 gesloten vragen met een vijfpuntsschaal van het Likert type gaande van geheel oneens naar geheel eens. Tevens was de optie niet te beoordelen/geen mening toegevoegd voor die gevallen waarbij het item niet van toepassing was.

De vorm van de enquête voor observatoren is identiek aan die van de studenten, alleen bevatte deze 11 gesloten vragen. De gebruikte lijst voor studenten en observatoren is te vinden in bijlage 5 en 6 .

\section{Respondenten}

Alle studenten en observatoren die deelnamen aan de vaardigheidstoetsen werd gevraagd na afloop van de toets de vragenformulieren in te vullen. Door de jaren heen werden deze formulieren door een ruime meerderheid van de studenten ingevuld. De respons over de laatste vijf jaar lag tussen de $60 \%$ en $95 \%$, hetgeen betekent dat elke enquête is ingevuld door 90 tot 143 studenten voor alle studiejaren. Het gemiddelde aantal studenten dat een vraag van de enquête heeft beantwoord bedraagt 119 . De respons van de observatoren lag vrijwel altijd tussen de $45 \%-75 \%$. Dit komt overeen met 27 tot 45 ingevulde enquêtes per toetsafname, en is mede afhankelijk van het aantal aanwezige (co)observatoren. Omdat sommige observatorschappen door meerdere observatoren vervuld worden, bijvoorbeeld de ene observator komt 's ochtends, de ander 's middags, bestaat er een redelijke spreiding in het aantal ingevulde enquêtes. De gegevens van de beide zesdejaars toetsen zijn bij elkaar opgeteld. Daarom ligt het absoluut aantal ingevulde enquêtes door observatoren hoger dan in de andere studiejaren en varieert dit aantal de afgelopen vijf jaren tussen de 43 en 68 . Het gemiddelde aantal 
observatoren dat de laatste vijf jaar over alle studiejaren heen een enquête invulde bedroeg 41 .

Deze verschillen in respons tussen studenten en observatoren zijn te verklaren uit het feit dat studenten soms persoonlijk baat kunnen hebben bij het invullen van de enquêtelijsten. Hun commentaar kan er in sommige gevallen toe leiden dat bepaalde onderdelen van het examen niet worden meegenomen in de beoordeling. Voor observatoren wordt het invullen vaak als een administratieve handeling gezien.

\section{Procedure}

De na-volgende gegevens hebben alleen betrekking op de som van de percentages van de ingevulde categorieën "geheel eens" en "eens". De percentages zijn afgerond op gehele getallen. Omdat men kan kiezen uit een vijfpuntsschaal met additioneel een niet te beoordelen optie betekent het complement van geheel eens/eens niet noodzakelijk oneens/geheel oneens, omdat met name de neutraal/geen mening optie bij enkele vragen vaak wordt ingevuld. In de meerderheid van de gevallen wordt echter weinig gebruik gemaakt van deze laatste categorieën zodat hier volstaan is met de weergave van de som van de percentages van de ingevulde categorieën "geheel eens" en "eens".

Tevens komt het voor dat per enquête niet altijd alle vragen zijn ingevuld.

De eerstejaars vaardigheidstoets was vóór het curriculumjaar 1989/90 gesplitst in een kortere toets (half uur) in het begin van het jaar en een langere toets aan het eind van het jaar (één uur). Voor de eerstejaars vaardigheidstoets zijn in de tabellen tot het curriculumjaar 1989/90 alleen de gegevens gebruikt van de deeltoets aan het eind van het jaar. Vanaf cursusjaar 1989/90 wordt de vaardigheidstoets in het eerste studiejaar in zijn geheel éénmaal per jaar afgenomen. 


\section{Resultaten}

\section{Afname vaardigheidstoetsen}

De inhoud van de vaardigheidstoets

De relevantie van de getoetste vaardigheden wordt door zowel de studenten als de observatoren hoog ingeschat. Gemiddeld meer dan 84 procent van de studenten vindt dat men deze vaardigheden nodig heeft als basisarts. De relevantie van de getoetste vaardigheid wordt in alle jaren ongeveer even hoog ingeschat en is onveranderlijk over de jaren heen (tabel 1).

Tabel 1: Weergave van de som van de percentages geheel eens/eens bij de vraag uit de standaard enquête afgenomen bij studenten aansluitend aan de vaardigheidstoets: "De meeste vaardigheden die ik moest demonstreren vind ik relevant voor de basisarts".

\begin{tabular}{lrrrrrr}
\hline Jaar & 1 & 2 & 3 & 4 & 5 & 6 \\
$82 / 83$ & 84 & 94 & 86 & 68 & 85 & 73 \\
$83 / 84$ & 94 & 86 & 93 & 88 & 88 & 63 \\
$84 / 85$ & 91 & 66 & 85 & 91 & 86 & 66 \\
$85 / 86$ & 88 & 92 & 79 & 94 & 90 & 87 \\
$86 / 87$ & 90 & 91 & 84 & 90 & 87 & 98 \\
$87 / 88$ & 84 & 94 & 86 & 83 & 73 & 97 \\
$88 / 89$ & 73 & 83 & 90 & 87 & 79 & 81 \\
$89 / 90$ & 83 & 78 & 87 & 89 & 90 & 91 \\
$90 / 91$ & 84 & 86 & 89 & 86 & 93 & 81 \\
$91 / 92$ & 89 & 87 & 93 & 74 & 93 & 88 \\
$92 / 93^{1}$ & 84 & 87 & 92 & 88 & - & 80 \\
\hline
\end{tabular}

I Vanaf $1992 / 93$ worden geen vijfdejaars toetsen meer afgenomen.

De vraagstelling naar de observatoren is complementair geformuleerd, nl. of men de vaardigheden overbodig vindt. 
Tabel 2: Weergave van de som van de percentages geheel eens/eens bij de vraag uit de standaard enquête afgenomen bij observatoren aansluitend aan de vaardigheidstoets: "Ik vind de vaardigheden die de studenten in mijn station moesten demonstreren overbodig".

\begin{tabular}{lrrrrrr}
\hline Jaar & 1 & 2 & 3 & 4 & 5 & 6 \\
$82 / 83$ & 6 & 13 & 2 & 4 & 4 & 9 \\
$83 / 84$ & 10 & 6 & 4 & 0 & 9 & 3 \\
$84 / 85$ & 9 & 8 & 2 & 2 & 5 & 0 \\
$85 / 86$ & 5 & 0 & 4 & 3 & 7 & 4 \\
$86 / 87$ & 5 & 0 & 6 & 9 & 9 & 6 \\
$87 / 88$ & 0 & 0 & 0 & 2 & 7 & 2 \\
$88 / 89$ & 8 & 4 & 2 & 2 & 4 & 4 \\
$89 / 90$ & 0 & 9 & 4 & 2 & 0 & 5 \\
$90 / 91$ & 3 & 10 & 7 & 0 & 17 & 2 \\
$91 / 92$ & 0 & 9 & 7 & 7 & 0 & 5 \\
$92 / 93^{1}$ & 0 & 4 & 4 & 5 & - & 2 \\
\hline
\end{tabular}

1 Vanaf 1992/93 worden geen vijfdejaars toetsen meer afgenomen.

Ja, vindt gemiddeld 5 procent (tabel 2). Het zou echter kunnen zijn dat observatoren bij deze vraag in grote getale de neutraal-optie hebben ingevuld. Dit blijkt niet het geval te zijn (gemiddeld $7 \%$ over de afgelopen vijf jaar). Gelet op de hoge percentages in de categorie (geheel) oneens (gemiddeld $80 \%$ over de afgelopen vijf jaar) verschillen observatoren en studenten derhalve nauwelijks in hun relevantie oordeel. Gevraagd is tevens of de praktijk van de gezondheidszorg zoals studenten die hebben meegemaakt goed wordt weerspiegeld in de toets. Hierbij vallen de oordelen duidelijk lager uit. Dit zal voor een groot deel te wijten zijn aan de toetssituatie, welke altijd een abstractie van de praktijk blijft. Bovendien zullen studenten in de eerste studiejaren aanzienlijk minder van de praktijk hebben gezien in vergelijking met studenten in de laatste twee studiejaren. Het is derhalve de vraag in hoeverre studenten in de beginfase van de studie de vraag zinvol kunnen beantwoorden. 
Tabel 3: Weergave van de som van de percentages geheel eens/eens bij de vraag uit de standaard enquête afgenomen bij studenten aansluitend aan de vaardigheidstoets: "Ik vond het circuit representatief voor wat ik in de praktijk heb gezien".

\begin{tabular}{lrrrrrr}
\hline Jaar & 1 & 2 & 3 & 4 & 5 & 6 \\
$82 / 83$ & 40 & 33 & 24 & 24 & 38 & 27 \\
$83 / 84$ & 53 & 23 & 41 & 27 & 57 & 47 \\
$84 / 85$ & 78 & 67 & 49 & 70 & 57 & 40 \\
$85 / 86$ & 34 & 40 & 29 & 45 & 59 & 65 \\
$86 / 87$ & 42 & 36 & 38 & 37 & 70 & 55 \\
$87 / 88$ & 48 & 40 & 41 & 42 & 42 & 48 \\
$88 / 89$ & 39 & 38 & 49 & 44 & 50 & 53 \\
$89 / 90$ & 42 & 32 & 30 & 44 & 85 & 62 \\
$90 / 91$ & 43 & 39 & 31 & 40 & 73 & 53 \\
$91 / 92$ & 43 & 56 & 49 & 40 & 89 & 74 \\
$92 / 93^{1}$ & 51 & 43 & 47 & 54 & - & 75 \\
& & & & & & \\
\hline
\end{tabular}

1 Vanaf 1992/93 worden geen vijfdejaars toetsen meer afgenomen.

Opvallend is echter wel dat de beoordeling in het vijfde en zesde studiejaar gunstiger uitvalt op dit punt na 1991. De doorgevoerde veranderingen in de vaardigheidstoets die als doel hadden, een betere aansluiting op de praktijksituatie van de co-assistent en die sedert $89 / 90$ (vijfde studiejaar) en 90/91 (zesde studiejaar) werden ingevoerd hebben klaarblijkelijk effect gehad, in vergelijking tot de resultaten uit de eerste vier studiejaren. Dit effect is echter voor het zesde studiejaar veel minder uitgesproken dan voor het vijfde studiejaar.

De vraag of het vaardigheidsniveau goed geëvalueerd wordt door de vaardigheidstoets, wordt door gemiddeld meer dan 74 procent van de observatoren bevestigend beantwoord.

De vierdejaars toets wordt in dit opzicht iets minder gewaardeerd. De gemiddelde score over alle jaren bedraagt hier $66 \%$, aldus de enquête (tabel 4). 
Tabel 4: Weergave van de som van de percentages geheel eens/eens bij de vraag uit de standaard enquête afgenomen bij observatoren aansluitend aan de vaardigheidstoets: "Ik vind de vaardigheidstoets een geschikte methode om het vaardigheidsniveau van studenten te evalueren".

\begin{tabular}{lcccccc}
\hline Jaar & 1 & 2 & 3 & 4 & 5 & 6 \\
$82 / 83$ & 64 & 88 & 84 & 70 & 67 & 81 \\
$83 / 84$ & 80 & 82 & 83 & 77 & 88 & 87 \\
$84 / 85$ & 86 & 95 & 68 & 64 & 86 & 62 \\
$85 / 86$ & 86 & 73 & 78 & 61 & 79 & 79 \\
$86 / 87$ & 96 & 67 & 71 & 65 & 61 & 69 \\
$87 / 88$ & 83 & 85 & 85 & 59 & 71 & 67 \\
$88 / 89$ & 71 & 73 & 76 & 68 & 72 & 65 \\
$89 / 90$ & 75 & 74 & 78 & 81 & 87 & 79 \\
$90 / 91$ & 77 & 71 & 67 & 67 & 74 & 68 \\
$91 / 92$ & 85 & 82 & 75 & 85 & 100 & 81 \\
$92 / 93^{1}$ & 90 & 76 & 76 & 84 & - & 78 \\
& & & & & & \\
\hline
\end{tabular}

Vanaf 1992/93 worden geen vijfdejaars toetsen meer afgenomen.

Uit de bijgeleverde commentaren valt op te maken dat dit te maken heeft met het studiegedrag van studenten. De vierdejaars toets speelt een belangrijke rol voor het behalen van het doctoraal examen (zie hoofdstuk 3 ) en studenten bereiden zich daar maximaal op voor. Dit houdt ondermeer in dat door een aantal studenten criterialijsten uit het hoofd worden geleerd. Dit leidt tot het opdreunen van rijtjes tijdens de toets. Observatoren beschouwen dit als een duidelijk negatief effect van de vaardigheidstoets. Aangezien dit verschijnsel het sterkst optreedt in het vierde studiejaar is dit een mogelijke verklaring voor de lagere waardering van de toets.

\section{Het gebruik van criterialijsten door observatoren}

Het valt op dat de bruikbaarheid van de criterialijst relatief laag wordt ingeschat (tabel 5). Over het algemeen wordt de bruikbaarheid van de checklijst lager ingeschat in de laatste twee studiejaren. De bruikbaarheid lijkt met name vanaf het curriculumjaar 91/92 in de hogere jaargroepen toe te nemen. Of dit te maken heeft met het feit dat de lijsten daadwerkelijk vormtechnisch meer zijn aangepast aan de wensen van de observator (globaliseren van items) of dat observatoren meer ervaren worden in het gebruik van de lijsten is niet geheel duidelijk. Een andere mogelijke verklaring is, dat het streven naar eenduidiger vormgeving van 
stations door de vaardigheidstoetsbeoordelingscommissie zich vertaald in een meer positieve waardering van de beoordelingslijst.

Tabel 5: Weergave van de som van de percentages geheel eens/eens bij de vraag uit de standaard enquête afgenomen bij observatoren aansluitend aan de vaardigheidstoets: "Ik vind de checklijst zeer bruikbaar".

\begin{tabular}{lllllll}
\hline Jaar & 1 & 2 & 3 & 4 & 5 & 6 \\
$82 / 83$ & 64 & 63 & 62 & 56 & 54 & 54 \\
$83 / 84$ & 50 & 58 & 58 & 61 & 56 & 57 \\
$84 / 85$ & 68 & 67 & 55 & 48 & 70 & 58 \\
$85 / 86$ & 68 & 58 & 64 & 63 & 42 & 63 \\
$86 / 87$ & 91 & 53 & 48 & 41 & 44 & 49 \\
$87 / 88$ & 61 & 60 & 57 & 63 & 67 & 62 \\
$88 / 89$ & 67 & 58 & 74 & 59 & 47 & 49 \\
$89 / 90$ & 75 & 61 & 65 & 57 & 60 & 52 \\
$90 / 91$ & 63 & 60 & 41 & 49 & 54 & 42 \\
$91 / 92$ & 76 & 77 & 57 & 85 & 79 & 70 \\
$92 / 93^{1}$ & 74 & 60 & 65 & 59 & - & 7 \\
& & & & & & \\
\hline
\end{tabular}

1 Vanaf 1992/93 worden geen vijfdejaars toetsen meer afgenomen.

Een mogelijke oorzaak voor de relatief geringe bruikbaarheid kan zijn dat observatoren te weinig tijd hebben om dergelijke lijsten in te vullen. Dit blijkt in de minderheid van de gevallen een mogelijke oorzaak te zijn (tabel 6).

De analyse van antwoorden bij de open vragen geeft echter enige aanvullende informatie. Eén van de argumenten voor de matige bruikbaarheid van criterialijsten is het veel voorkomende commentaar dat de lijst -in relatie tot de uit te voeren vaardigheid- te gedetailleerd zou zijn. Het betreft met name de items die betrekking hebben op het proces van de handeling. Deels roept dit vragen op met betrekking tot het dwingende en uniforme karakter ervan, aangezien er in sommige gevallen mogelijk meerdere varianten bestaan om een vaardigheid uit te voeren. Deels maakt de gedetailleerde uitsplitsing van de vaardigheid sommige items triviaal. 
Tabel 6: Weergave van de som van de percentages geheel eens/eens bij de vraag uit de standaard enquête afgenomen bij observatoren aansluitend aan de vaardigheidstoets: "Ik had onvoldoende tijd om de observatieformulieren in te vullen".

\begin{tabular}{lrrrrrr}
\hline Jaar & 1 & 2 & 3 & 4 & 5 & 6 \\
$82 / 83$ & 15 & 0 & 22 & 19 & 10 & 22 \\
$83 / 84$ & 20 & 20 & 12 & 17 & 15 & 17 \\
$84 / 85$ & 14 & 10 & 21 & 19 & 6 & 27 \\
$85 / 86$ & 14 & 13 & 17 & 11 & 21 & 4 \\
$86 / 87$ & 14 & 8 & 19 & 19 & 16 & 18 \\
$87 / 88$ & - & - & - & - & -14 & 16 \\
$88 / 89$ & 38 & 8 & 10 & 24 & 14 & 8 \\
$89 / 90$ & 11 & 14 & 9 & 17 & 13 & 12 \\
$90 / 91$ & 7 & 17 & 17 & 15 & 14 & 11 \\
$91 / 92$ & 6 & 7 & 14 & 7 & - & \\
$92 / 93^{1}$ & 13 & 7 & 9 & 11 & & \\
& & & & & & \\
\hline
\end{tabular}

Vanaf $1992 / 93$ worden geen vijfdejaars toetsen meer afgenomen.

Een ander kritiekpunt met betrekking tot de bruikbaarheid van de criterialijst is dat het gewicht van de gedetailleerde items, met name die betrekking hebben op de uitvoering van de handeling, soms zo zwaar meetellen dat hiermee foute resultaten of uitkomsten van onderzoek gecompenseerd kunnen worden. Dit doet volgens sommige observatoren de werkelijkheid geweld aan.

De bruikbaarheid van de criterialijst kan ook afhangen van het feit of de observator voorafgaand aan de toets de training voor observatoren heeft gevolgd, waarbij het gebruik van de criterialijst uitvoerig wordt besproken. Wanneer een training niet gevolgd wordt, blijft deze informatie achterwege waardoor de criterialijst mogelijk moeilijker hanteerbaar wordt voor een aantal observatoren.

\section{Voorbereiding/training van observatoren}

Uit de aanwezigheidsregistraties blijkt dat de trainingen voor observatoren met name in de beginfase van de vaardigheidstoets redelijk goed worden bezocht. Later wordt dit minder. Het percentage observatoren dat in het cursusjaar 1992/93 de training volgde lag op ongeveer vijftig procent (Van Luijk et al., 1993). Hierbij dient men er echter wel rekening mee te houden dat tot de observatoren die niet op de training 
verschijnen ook zeer ervaren observatoren behoren. Bij deze laatste groep is het de vraag of ze op een training aanwezig moeten zijn. Steeds minder observatoren geven aan de trainingen een goede voorbereiding te vinden (tabel 7). Een verklaring hiervoor kan zijn dat indien men al ooit eerder instructie heeft gehad om een station te observeren voor een vaardigheidstoets het niet meer nodig gevonden wordt om nog eens opnieuw instructies te krijgen. Deze opvatting van observatoren is strijdig met waarnemingen vanuit de praktijk van de trainingen waaruit blijkt dat het juist erg nuttig kan zijn dat observatoren hun ervaringen met bestaande criterialijsten in een trainingssituatie inbrengen zodat mogelijk afspraken over interpretaties aangescherpt kunnen worden en inhoudelijke/procedurele verbeteringen kunnen worden geëffectueerd.

Tabel 7: Weergave van de som van de percentages geheel eens/eens bij de vraag uit de standaard enquête afgenomen bij observatoren aansluitend aan de vaardigheidstoets: "De observatortraining vormde voor mij een goede voorbereiding op mijn rol als observator".

\begin{tabular}{lrrrrrr}
\hline Jaar & 1 & 2 & 3 & 4 & 5 & 6 \\
$82 / 83$ & 57 & 38 & 62 & 60 & 51 & 69 \\
$83 / 84$ & 30 & 18 & 52 & 51 & 47 & 40 \\
$84 / 85$ & 46 & 62 & 39 & 40 & 41 & 62 \\
$85 / 86$ & 64 & 53 & 62 & 53 & 37 & 42 \\
$86 / 87$ & 36 & 37 & 44 & 37 & 40 & 57 \\
$87 / 88$ & 39 & 40 & 51 & 39 & 36 & 44 \\
$88 / 89$ & 46 & 54 & 30 & 41 & 37 & 41 \\
$89 / 90$ & 17 & 37 & 20 & 53 & 17 & 61 \\
$90 / 91$ & 30 & 29 & 35 & 33 & 26 & 52 \\
$91 / 92$ & 39 & 39 & 36 & 48 & 26 & 30 \\
$92 / 93^{1}$ & 45 & 18 & 28 & 49 & - & 32 \\
\hline
\end{tabular}

I Vanaf 1992/93 worden geen vijfdejaars toetsen meer afgenomen.

Daarnaast blijkt uit de gegeven open antwoorden dat er bij een aantal observatoren kritiek bestaat op de kwaliteit van de training. Met name mist men de feitelijke oefening in het scoren van vaardigheden.

Wanneer nagegaan wordt waarom observatoren niet op de training verschijnen, wordt vaak als reden aangevoerd dat het niet nodig gevonden wordt om op de eigen vakspecifieke deskundigheid instructies 
te krijgen. In dergelijke gevallen onderkent de observator waarschijnlijk onvoldoende dat er in een instructie met name op andere aspecten gelet wordt. Gedacht kan worden aan interpretatieverschillen over items, procedurele gang van zaken en administratieve handelingen die tijdens een toets verricht moeten worden. Gelet op de kritiek van observatoren en de absentie bij trainingen zou een nadere studie gedaan moeten worden naar het nut van trainingen. Trainingseffecten in relatie tot de achtergrondkennis van de observator zijn reeds eerder onderzocht (Van der Vleuten et al., 1989-A). Zinvol lijkt eveneens om na te gaan of commentaar van studenten op observatoren verband hebben met het al of niet aanwezig geweest zijn op een training.

Tabel 8: Weergave van de som van de percentages geheel eens/eens bij de vraag uit de standaard enquête afgenomen bij observatoren aansluitend aan de vaardigheidstoets: "Het was mij in alle opzichten duidelijk wat er van mij als observator werd verwacht".

\begin{tabular}{lcccccc}
\hline Jaar & 1 & 2 & 3 & 4 & 5 & 6 \\
$82 / 83$ & 83 & 75 & 88 & 85 & 83 & 75 \\
$83 / 84$ & 85 & 75 & 79 & 90 & 83 & 90 \\
$84 / 85$ & 82 & 77 & 89 & 86 & 88 & 96 \\
$85 / 86$ & 91 & 83 & 91 & 90 & 86 & 96 \\
$86 / 87$ & 91 & 82 & 83 & 83 & 77 & 88 \\
$87 / 88$ & 87 & 90 & 79 & 78 & 86 & 91 \\
$88 / 89$ & 96 & 85 & 86 & 81 & 74 & 82 \\
$89 / 90$ & 86 & 84 & 87 & 83 & 83 & 82 \\
$90 / 91$ & 90 & 83 & 70 & 91 & 72 & 85 \\
$91 / 92$ & 91 & 80 & 75 & 81 & 94 & 88 \\
$92 / 93^{1}$ & 84 & 73 & 78 & 95 & - & 80
\end{tabular}

t Vanaf 1992/93 worden geen vijfdejaars toetsen meer afgenomen.

Uit een vergelijking tussen de tabellen zeven en acht blijkt dat het niet volgen van een observatortraining nauwelijks invloed heeft op de duidelijkheid van de observatorrol (tabel 8). Uit de praktijk blijkt dat die duidelijkheid waarschijnlijk reeds in voldoende mate wordt verkregen wanneer de observator minimaal éénmaal aan de vaardigheidstoets heeft deelgenomen. 
Mening van studenten over (co-)observatoren

Omdat de vaardigheidstoets veel stress veroorzaakt bij studenten (Driessen, 1987; Bartstra, 1987; Visser et al., 1993) is de houding van observatoren naar studenten toe erg belangrijk. Gemiddeld vindt ongeveer zestig procent van de studenten dat observatoren hem/haar gerust stellen (tabel 9). Vergeleken bij de start van de toetsen neemt de waardering voor de observatoren in dit opzicht toe. Mogelijk heeft dit te maken met het feit dat observatoren steeds meer ervaring opbouwen en zich derhalve meer vertrouwd gaan voelen met deze vorm van toetsing.

Tabel 9: Weergave van de som van de percentages geheel eens/eens bij de vraag uit de standaard enquête afgenomen bij studenten aansluitend aan de vaardigheidstoets: "De meeste observatoren probeerden mij gerust te stellen".

\begin{tabular}{lrrrrrr}
\hline Jaar & 1 & 2 & 3 & 4 & 5 & 6 \\
$82 / 83$ & 69 & 47 & 35 & 41 & 53 & 31 \\
$83 / 84$ & 61 & 48 & 39 & 53 & 57 & 54 \\
$84 / 85$ & 61 & 62 & 50 & 67 & 69 & 60 \\
$85 / 86$ & 71 & 69 & 52 & 67 & 65 & 72 \\
$86 / 87$ & 65 & 67 & 55 & 54 & 58 & 78 \\
$87 / 88$ & 64 & 68 & 66 & 54 & 63 & 70 \\
$88 / 89$ & 64 & 72 & 59 & 59 & 63 & 56 \\
$89 / 90$ & 69 & 61 & 64 & 48 & 60 & 60 \\
$90 / 91$ & 58 & 58 & 66 & 61 & 58 & 61 \\
$91 / 92$ & 78 & 67 & 80 & 57 & 67 & 75 \\
$92 / 93^{1}$ & 62 & 63 & 62 & 66 & - & 70 \\
& & & & & & \\
\hline
\end{tabular}

Vanaf 1992/93 worden geen vijfdejaars toetsen meer afgenomen.

Er is sprake van een geleidelijke toename in waardering met betrekking tot de aanwezigheid van co-observatoren bij het vorderen van de studie. Dit komt wellicht doordat de ouderejaars graag een extra controle zien op het invullen van hun criterialijsten, die in een aantal gevallen complexer en de laatste jaren vaak globaler van opzet zijn dan die van de eerste studiejaren (tabel 10). 
Tabel 10: $\quad$ Weergave van de som van de percentages geheel eens/eens bij de vraag uit de standaard enquête afgenomen bij studenten aansluitend aan de vaardigheidstoets: "Ik vond het goed dat er co-observatoren waren".

\begin{tabular}{lllllll}
\hline Jaar & 1 & 2 & 3 & 4 & 5 & 6 \\
$82 / 83$ & 34 & 34 & 37 & 61 & 65 & 64 \\
$83 / 84$ & 21 & 38 & 51 & 30 & 29 & 54 \\
$84 / 85$ & 33 & 41 & 37 & 45 & 47 & 62 \\
$85 / 86$ & 43 & 46 & 43 & 53 & 51 & 52 \\
$86 / 87$ & 27 & 54 & 46 & 42 & 45 & 50 \\
$87 / 88$ & 38 & 40 & 52 & 40 & 58 & 58 \\
$88 / 89$ & 41 & 47 & 53 & 63 & 45 & 59 \\
$89 / 90$ & 31 & 50 & 47 & 36 & 61 & 55 \\
$90 / 91$ & 41 & 50 & 45 & 63 & 51 & 67 \\
$91 / 92$ & 42 & 12 & 42 & 40 & 57 & 52 \\
$92 / 93^{1}$ & 41 & 54 & 52 & 53 & - & 39 \\
\hline
\end{tabular}

Vanaf $1992 / 93$ worden geen vijfdejaars toetsen meer afgenomen.

De relatief lage waardering voor de aanwezigheid van co-observatoren in de eerste jaren van de studie kan te maken hebben met het gevoel dat extra personen in de ruimte waar getoetst wordt voor deze groep meestal stressverhogend werkt. Studenten in de hogere jaargroepen zouden hier wat minder last van kunnen hebben doordat ze meer ervaren zijn in het afleggen van deze examens.

Bijna negentig procent van de studenten zegt feedback van de observator prettig te vinden, dit is nagenoeg constant over de jaren heen (tabel 11). Dit is een opvallend gegeven aangezien door sommige observatoren beweerd wordt dat men studenten tijdens toetssituaties juist géén feedback moet geven, omdat ze dan zo nerveus zouden worden in het geval van negatieve feedback, dat andere toetsonderdelen daardoor slechter doorlopen zouden worden. Bovendien mag uit deze tabel geconcludeerd worden dat observatoren kennelijk in staat zijn om zinvolle feedback te geven. 
Tabel 11: Weergave van de som van de percentages geheel eens/eens bij de vraag uit de standaard enquête afgenomen bij studenten aansluitend aan de vaardigheidstoets: "Ik vond het prettig feedback te krijgen van de observatoren".

\begin{tabular}{lrrrrrrr}
\hline Jaar & 1 & 2 & 3 & 4 & 5 & 6 \\
$82 / 83$ & 88 & 96 & 91 & 88 & 72 & 82 \\
$83 / 84$ & 92 & 93 & 89 & 82 & 86 & 93 \\
$84 / 85$ & 90 & 87 & 82 & 89 & 98 & 74 \\
$85 / 86$ & 91 & 90 & 83 & 90 & 86 & 93 \\
$86 / 87$ & 82 & 94 & 86 & 93 & 90 & 88 \\
$87 / 88$ & 86 & 93 & 88 & 90 & 85 & 93 \\
$88 / 89$ & 87 & 90 & 83 & 90 & 93 & 87 \\
$89 / 90$ & 87 & 91 & 85 & 81 & 90 & 88 \\
$90 / 91$ & 88 & 85 & 86 & 92 & 86 & 83 \\
$91 / 92$ & 88 & 89 & 87 & 81 & 84 & 88 \\
$92 / 93^{1}$ & 88 & 90 & 90 & 88 & - & 72 \\
\hline
\end{tabular}

Vanaf 1992/93 worden geen vijfdejaars toetsen meer afgenomen.

\section{Andere relevante ervaringen met de vaardigheidstoets}

Een punt dat niet eerder genoemd is in dit hoofdstuk omdat dit niet in de reguliere vragenlijsten naar voren komt maar wel vaak bij de open vragen spontaan wordt vermeld betreft het feit dat de vaardigheidstoets erg veel stress veroorzaakt bij studenten en een sterk sturende invloed heeft op het studiegedrag (Driessen, 1987; Bartstra, 1987; Van Luijk et al., 1990; Visser et al., 1993). Dit zal voor een deel samenhangen met de belangrijke plaats die de vaardigheidstoets inneemt binnen het examensysteem (zie hoofdstuk drie).

Studenten blijken een aantal weken voor de toets hun studieactiviteiten langzamerhand geheel te verleggen naar de voorbereiding op de vaardigheidstoets. Hierdoor hebben andere onderwijsactiviteiten nauwelijks meer belangstelling van de student. Dit vormt een probleem voor degenen die op dat moment verantwoordelijk zijn voor het onderwijs. 


\section{Samenvatting en conclusie}

Het gebruik van vragenlijsten om meningen te verzamelen heeft als nadeel dat het in de regel veel ruimte voor interpretaties open laat. Dat is ook hier het geval. Toch wordt de interpretatie gemakkelijker doordat gegevens gebaseerd zijn op het gedurende tien jaar afnemen van dezelfde enquêtes in omstandigheden waarbij ook vaak nog aanvullend mondeling commentaar wordt gegeven. Daarnaast wordt de interpretatie bevorderd doordat gegevens beschikbaar zijn uit de open antwoordcategorieën die studenten en observatoren schriftelijk kunnen invullen.

Wanneer men bovenstaande ervaringen over de effecten van stationsexamens richt op de punten die in dit hoofdstuk worden uitgediept komt men tot de volgende conclusies.

Op het punt van de inhoudsvaliditeit van de stationsexamens kan men stellen dat deze gezien de relevantiebeoordelingen ten aanzien van de inhoud van de toets van redelijk niveau is. Desalniettemin heeft men vaak kritiek op het fragmentarisch karakter van de stations. Vandaar dat de neiging bestaat bij toetsconstructeurs om steeds meer onderdelen van een consult te toetsen (of gehele consulten). Dit heeft als gevolg dat in de meeste gevallen de stationsduur steeds verder uitgebreid wordt (zie hoofdstuk 2).

Ondanks het feit dat trainingen voor observatoren slecht bezocht worden, blijken observatoren redelijk op de hoogte te zijn van wat er van hen verwacht wordt. Wellicht komt dit doordat observatoren na éen keer observeren op de hoogte zijn van de procedure van de toets. Tevens speelt een rol dat steeds meer observatoren ervaring opdoen in hun rol als observator. Gelet op de inspanning die het kost om voor elke toets voor elk station een training te organiseren verdient het aanbeveling nog eens kritisch de noodzakelijkheid, vormgeving en inhoud van trainingen nader te onderzoeken.

Over de bruikbaarheid van criterialijsten wordt door observatoren verschillend gedacht. Zo wordt de (meestal gedetailleerde) beoordelingslijst soms als een nuttig hulpmiddel gezien om tot een betrouwbaar oordeel over de student te komen. Anderzijds ervaren observatoren een dergelijke lijst vaak als een keurslijf. De beoordelingslijst biedt onvoldoende ruimte om gebruik te maken van de eigen deskundigheid om eventuele nuanceringen in een oordeel over studenten aan te brengen. Tevens hebben gedetailleerde criterialijsten het grote nadeel dat studenten gestimuleerd worden deze lijsten uit het hoofd te leren. Het uit het hoofd leren helpt zeker bij de voorbereiding van een vaardigheids- 
toets. Dit gaat echter vaak ten koste van de daadwerkelijke uitvoering van de vaardigheid en het begrip waarom een bepaalde vaardigheid juist in die situatie op die manier moet worden uitgevoerd. Dat globale criterialijsten prettiger ervaren worden blijkt uit de toegenomen waardering van de beoordelingslijst in het vijfde en zesde studiejaar. Eveneens roept de mate van detaillering van sommige items vragen op ten aanzien van de zwaarte van bepaalde (minder relevante) items ten opzichte van andere (relevante) items. Observatoren geven vaak te kennen dat essentiële items op de criterialijst te weinig voorkomen, en daar waar ze voorkomen meer dan gecompenseerd kunnen worden door de relatief gemakkelijke items. Als moeilijke items worden met name die items beschouwd die te maken hebben met uitkomsten en interpretatie van onderzoek. Makkelijke items zijn de items die te maken hebben met de procedure en de systematiek van de vaardigheid.

De benadering van studenten door observatoren is in het algemeen geruststellend, hoewel verbeteringen in dit opzicht zeker nog mogelijk zijn op basis van de vele schriftelijke commentaren op bepaalde observatoren na de toets. 


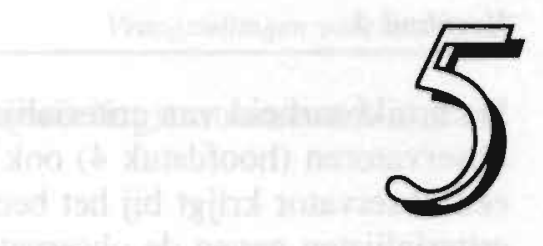

\section{VRAAGSTELLINGEN VOOR ONDERZOEK}

De voorafgaande hoofdstukken hebben gediend als context voor de vraagstellingen die in de volgende hoofdstukken aan bod komen. In hoofdstuk 1 is aangegeven dat studenten de vaardigheden die nodig zijn voor de latere beroepsuitoefening eerst gedetailleerd en stap voor stap aanleren op basis van de standaarden voor lichamelijk onderzoek. Vervolgens worden de vaardigheden getoetst door middel van gedetailleerde criterialijsten in een vaardigheidstoets met de kenmerken van een OSCE (hoofdstukken 2 en 3). In hoofdstuk 4 is weergegeven dat observatoren de gedetailleerde criterialijsten niet bruikbaar vinden. Als één van de redenen wordt aangegeven dat relevante beoordelingscriteria, door de grote hoeveelheid minder relevante beoordelingscriteria niet genoeg doorwerken in het uiteindelijke oordeel over de student. Dit geeft observatoren het gevoel dat studenten met name worden beoordeeld op basis van minder relevant geachte criteria.

In hoofdstuk zes wordt nagegaan in hoeverre er daadwerkelijk sprake is van een scheve verdeling tussen beoordelingscriteria die als relevant of minder relevant worden beschouwd. Vervolgens wordt bekeken in hoeverre toetsresultaten zouden veranderen indien de vaardigheidstoets alleen bepaalde relevante of minder relevante beoordelingscriteria zou bevatten. Eveneens wordt de betrouwbaarheid van de verschillende beoordelingscriteria nagegaan. 
De bruikbaarheid van criterialijsten wordt blijkens commentaren van observatoren (hoofdstuk 4) ook bepaald door de interpretatievrijheid die een observator krijgt bij het beoordelen van studenten. Gedetailleerde criterialijsten geven de observator weinig "vrijheid". De beoordelaar kan in die gevallen alleen aangeven of een vaardigheid goed dan wel fout verricht is. Globale beoordelingsschalen maken kwalitatieve oordelen van observatoren wel in zekere mate mogelijk. Criterialijsten met dergelijke beoordelingsschalen worden dan ook beter gewaardeerd. Van gedetailleerde criterialijsten is echter bekend dat deze tot een hogere interbeoordelaarsbetrouwbaarheid leiden dan globale criterialijsten. Dit was oorspronkelijk ook de reden voor het construeren van gedetailleerde beoordelingsschalen. De vraag is echter of het verschil in interbeoordelaarsbetrouwbaarheid tussen beide beoordelingsschalen zich ook vertaalt in een verschil voor wat betreft de totale betrouwbaarheid van de toets. In hoofdstuk zeven wordt nagegaan in hoeverre de totale toetsbetrouwbaarheid van de vaardigheidstoets verandert bij gebruik van gedetailleerde (analytische) en globale beoordelingsschalen.

De cesuur van de vaardigheidstoets is in het verleden mede tot stand gekomen op basis van een globale beoordeling van de inhoud. Het aantal studenten dat niet aan de norm voldeed heeft eveneens een rol gespeeld bij de definitieve vaststelling van de cesuur. In hoofdstuk 3 is aangegeven hoe de cesuur van de vaardigheidstoets op dit moment wordt vastgesteld. Er zijn echter meerdere methoden om tot een normstelling te komen. In hoofdstuk 8 wordt een overzicht gegeven van de verschillende methoden. Deze methoden worden toegepast op de vaardigheidstoets. Beoordeeld wordt in hoeverre de huidige cesuur afwijkt van andere cesuren.

In het algemeen hebben studies over de predictieve validiteit van examens voor toekomstig functioneren binnen de medische studie, betrekking op de relatie tussen resultaten behaald bij kennistoetsing op middelbare scholen of toelatingsexamens voor de medische studie en resultaten van kennistoetsing binnen de medische opleiding. Predictieve validiteitsstudies over stationsexamens zijn nog zeer schaars. Vandaar dat in hoofdstuk 9 wordt ingegaan op de predictieve validiteit van de vaardigheidstoets van de eerste vier studiejaren ten opzichte van de laatste twee studiejaren. Als referentiepunt wordt tevens de predictieve validiteit van de voortgangstoets (zie hoofdstuk 3 ) onderzocht. 
Beoordeeld wordt in welke mate beide beoordelingsinstrumenten succes binnen de stages kunnen voorspellen. 


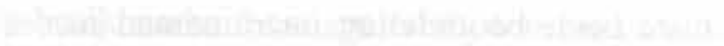




\section{6}

\section{EEN INHOUDELIJKE ANALYSE VAN DE VAARDIGHEIDSTOETS}

\section{Inleiding}

Op grond van de jarenlange ervaring met de vaardigheidstoets viel na verloop van tijd een aantal effecten op welke mogelijk toe te schrijven waren aan de opbouw en de structuur van het meetinstrument zelf. In dit hoofdstuk komen met name effecten aan de orde welke gerelateerd zijn aan de operationalisatie van de inhoud van de studiestof in items van criterialijsten. De vaardigheid die studenten aanleren is conform de standaarden opgesplitst in de kleinst mogelijke zinvolle eenheden van motorisch of cognitief handelen. Hieraan ligt het idee ten grondslag dat de meest efficiënte manier om vaardigheden aan te leren de "stap voor stap" methode is. Dit houdt in dat complexe vaardigheden worden opgesplitst in deelvaardigheden die afzonderlijk worden getraind. Aan het eind van dit leerproces worden de diverse aangeleerde deelvaardigheden geïntegreerd geoefend. Dit zal dan uiteindelijk tot beheersing van de complexe vaardigheid leiden.

Bij de constructie van criterialijsten is gebruik gemaakt van de opsplitsing in deelvaardigheden. Immers de elementen waaruit de uitgesplitste vaardigheid bestond kunnen direct gebruikt worden als

Delen van dit hoofdstuk zijn reeds eerder verschenen in: Van Luijk, S.J., Van der Vleuten, C.P.M. \& Van Schelven, R.M. (1990) The relation between content and psychometric characteristics in performance-based testing. In: Bender, W., Hiemstra, R.J., Scherpbier, A.J.J.A. \& Zwierstra, R.P. (Eds.) Teaching and Assessing Clinical Competence. Groningen: Boekwerk Publ. 
beoordelingscriteria bij de criterialijst. Op die manier kunnen met minimale wijzigingen de criterialijsten rechtstreeks afgeleid worden uit de standaarden.

De toepassing van de aldus verkregen criterialijsten leverde in toenemende mate kritiek op van observatoren. Twee problemen werden met name gesignaleerd.

Het eerste probleem spitste zich toe op de inhoudelijke eigenschappen van items. Doordat criterialijsten afgeleid zijn van de standaarden bevatten de lijsten zeer veel items die betrekking hebben op het uitvoeren van de handeling (het proces) en weinig items die betrekking hebben op de uitkomst van de handeling (het produkt). Bij de observatoren bestond de indruk dat procesitems veel beter uitgevoerd werden dan produktitems. De "scheve verdeling" van soorten items leidde ertoe dat er een gevoel ontstond van "de studenten kunnen de handelingen goed uitvoeren maar weten niet hoe ze de op die manier verkregen gegevens moeten interpreteren".

Een tweede probleem, ook samenhangend met de inhoudelijke eigenschappen van items, betrof het feit dat studenten veelal rijtjes items uit het hoofd opnoemden zonder dat de observator het gevoel had dat er daadwerkelijk sprake was van begrip. De items die zich hier met name voor leenden waren items die kenniselementen binnen de vaardigheid vertegenwoordigden. Dit type items kwam binnen criterialijsten veel voor. Het uit het hoofd leren van criterialijsten werd daardoor voor studenten een zeer zinvolle strategie. Onbedoeld werd daarmee een memoriserende studiestrategie bevorderd ten koste van een begripsmatige strategie.

De gepercipieerde grote hoeveelheid naar kennis verwijzende "cognitieve items" zouden in vergelijking tot de meer "handelingsgerichte" items op deze manier veel zwaarder doorwerken in de beoordeling van de student en derhalve de hierboven omschreven mening van observatoren versterken.

In de literatuur wordt een aantal classificaties van vaardigheden beschreven. Zo onderscheidt Singleton (1978) vaardigheden gericht op input, output en cognitie. De vaardigheden gericht op input zijn de meer zintuiglijke waarnemingen, dat wil zeggen vaardigheden gericht op dataverzameling. De meer output gerichte vaardigheden zijn de motorische handelingen. De cognitieve vaardigheden worden geassocieerd met het "weten", hoewel ook aangegeven wordt dat het 
onderscheid tussen cognitief enerzijds en input en output vaardigheden anderzijds moeilijk aan te geven is.

Een andere classificatie die in hoofdstuk 1 aangegeven wordt betreft die van de Block en Heene (1986). Zij maken een onderscheid tussen verschillende gedragsniveaus (weten, inzien, toepassen (=kunnen), integreren) waarbij op elk niveau een onderscheid gemaakt wordt tussen meer motorische, meer cognitieve of meer dynamisch-affectieve aspecten. De gedragsniveaus zijn hiërarchisch gestructureerd, met andere woorden om te kunnen toepassen moet er eerst "geweten worden" en inzicht bestaan. In relatie tot de eerder gepercipieerde dimensies lijken ook hier procesmatige handelingen (weten, toepassen) naast produktmatige handelingen (inzien, integreren) te worden onderscheiden. Eveneens worden ook in dit model cognitieve (weten, inzien, integreren) en psychomotore aspecten (toepassen) beschreven.

Bovenstaande indelingen zouden ook toepasbaar moeten zijn op vaardigheden gericht op het medisch domein. Omdat de medische vaardigheden bij de vaardigheidstoets uitgesplitst worden in de kleinst mogelijke zinvolle eenheden van handeling zouden items relatief eenvoudig te classificeren moeten zijn volgens bovenstaande categorieën. Er werd gekozen om items in te delen in de classificatie cognitief versus motorisch enerzijds en procesmatig handelen versus produktmatig handelen anderzijds.

Indien deze inhoudelijke classificatie toepasbaar blijkt kan deze gerelateerd worden aan de ervaringen van observatoren met betrekking tot het gebruik van gedetailleerde criterialijsten. Tevens wordt het mogelijk (op een andere manier dan gebruikelijk) eventuele sterke en zwakke punten van studenten en daarmee van het onderwijs op te sporen.

\section{Probleemstelling}

Dit hoofdstuk is met name gericht op een analyse van de inhoud van de vaardigheidstoets. Hierbij wordt getracht op basis van een inhoudelijke classificatie te komen tot het bepalen van de aanwezigheid van verschillende inhoudelijke kenmerken binnen toetsen. Onderzocht wordt, op basis van een frequentieverdeling tussen de verschillende groepen items, of en in hoeverre een scheve verdeling bestaat tussen de 
verschillende groepen items. Bovendien zal worden nagegaan of en in hoeverre de verschillende inhoudelijke groepen items van de toets de betrouwbaarheid en validiteit beïnvloeden. De gebruikte classificatie is gebaseerd op twee categorieën, namelijk motorisch versus cognitief handelen en procesmatig versus produktmatig handelen.

Nagegaan wordt in hoeverre de te onderscheiden categorieën gerepresenteerd worden in de toets. Op grond van de commentaren van observatoren mag men verwachten dat de items met cognitieve en procesmatige kanten het meest frequent voorkomen. Als dit bij de vierde en zesde jaars toets inderdaad het geval is, zal - gezien de blauwdruk van de vaardigheidstoetsen (hoofdstuk 3 ) - dit beeld bij de toetsen van andere jaren alleen nog meer uitgesproken zijn.

Cognitieve items, die goed uit het hoofd geleerd kunnen worden zullen naar verwachting tot hogere scores leiden dan andere items. Ook items die betrekking hebben op procesmatig handelen zullen naar verwachting beter gemaakt worden door de studenten, aangezien procesitems direct aansluiten op het gegeven onderwijs en het slechts alleen theoretisch bekend zijn met de inhoud snel kan leiden tot een positief beoordelingsresultaat, met name ook omdat het vrij basale kennis betreft.

Wanneer verwacht wordt dat bepaalde soorten items veel gemakkelijker zijn dan andere en eventueel daardoor een compenserende werking kunnen hebben op de minder goed gescoorde items, lijkt het zinvol na te gaan in hoeverre vaardigheidstoetsuitslagen anders zouden uitvallen wanneer ze alleen uit items zouden bestaan van slechts één categorie. Hiertoe worden de reguliere toetsuitslagen van studenten uitgezet tegen elk van de beoordelingscategorieën. Verwacht mag worden dat toetsen gebaseerd op procesitems en cognitieve items tot betere resultaten leiden, dat wil zeggen tot meer voldoende kwalificaties. Op grond van het commentaar dat studenten wel weten wat ze moeten doen maar niet begrijpen wat ze doen, mag ook verwacht worden dat vaardigheidstoetsuitslagen alleen gebaseerd op produktmatige items tot meer onvoldoende toetsscores zullen leiden.

Om dit te onderzoeken zijn overzichtstabellen gemaakt waarin kwalificaties behaald op de reguliere vaardigheidstoets per student worden afgezet tegen de kwalificaties per student per beoordelingscategorie.

Ten aanzien van de betrouwbaarheid, hier uitgedrukt in een generaliseerbaarheidscoëfficiënt (Brennan, 1983), wordt nagegaan in hoeverre de 
verschillende beoordelingscategorieën een verschillende betrouwbaarheid laten zien.

Op grond hiervan zou men de effecten van inhoudelijke veranderingen binnen de vaardigheidstoets (bijvoorbeeld het maken van examenmateriaal waarbij veel meer items uit de beoordelingscategorie "procesitems" aan bod komen) kunnen uitdrukken in een veranderende generaliseerbaarheidscoëfficient.

De invloed op de validiteit is op twee manieren onderzocht. In de eerste plaats zijn de correlationele verbanden tussen de verschillende inhoudsgebieden bepaald. Gezien het feit dat de inhoudelijke betekenis van deze inhoudsgebieden nogal verschilt, worden over het algemeen geen hoge correlaties verwacht.

In de tweede plaats, is de schriftelijke toets die gericht is op het meten van algemeen medische kennis, de voortgangstoets, als uitgangspunt genomen. Hierbij wordt verwacht dat de cognitieve items een hoger verband met dit meetinstrument vertonen dan primair motorisch gerichte items. Er zijn geen redenen om te veronderstellen dat proces en produktitems op verschillende wijze met de voortgangstoets zouden correleren.

\section{Methode}

\section{Subjecten}

Als object van studie werden de reguliere vaardigheidstoets van het vierde en één van de reguliere toetsen uit het zesde studiejaar van het curriculumjaar $87 / 88$ genomen. De keuze voor deze twee jaargroepen werd bepaald door de relevantie van de toets in relatie tot de studievoortgang. Deze toetsen hebben een duidelijk selecterende functie voor het doctoraal en artsexamen en de beschreven problemen kunnen hier de meest verstrekkende consequenties hebben.

De vierdejaars toets omvatte drie parallelle circuits, elk met maximaal 48 studenten. De zesdejaars toets bestond uit vier circuits, waaraan per circuit maximaal 12 studenten konden deelnemen. In totaal namen 126 studenten deel aan de vierdejaars toets en 48 studenten aan de zesdejaars toets. 


\section{Materiaal}

De twee onderzochte jaargroepen hebben samen 29 verschillende stations doorlopen, met een totaal van 1575 items (zie ook tabel 1). Het aantal items per station varieert van 17 tot 84 . Stations die in meerdere circuits voorkwamen werden uit het materiaal verwijderd. Dit om een zuiver beeld te krijgen van het totaal van het "unieke geproduceerde" toetsmateriaal. Met name voor de zesdejaars toets waarbij opeenvolgende circuits vrijwel identiek waren maakt het verwijderen van dubbele stations veel uit (tabel 1 , zie later).

Alle items van de gebruikte toetsen werden ingedeeld volgens de categorieën cognitief versus motorisch handelen enerzijds en procesmatig versus produktmatig handelen anderzijds. De diverse toe te kennen categorieën werden als volgt gedefinieerd:

Psychomotore items (Motorisch):

Items die inhoudelijk en in eerste instantie vooral gerelateerd zijn aan een zichtbare psychomotore activiteit relevant voor het uitvoeren van een handeling (overt gedrag).

Cognitieve items (Cognitief):

Items die inhoudelijk en in eerste instantie niet gerelateerd zijn aan zichtbare psychomotore activiteit relevant voor het uitvoeren van een vaardigheid (covert gedrag).

Proces items (Proces):

Items die inhoudelijk en in eerste instantie gerelateerd zijn aan de uitvoering van de vaardigheid.

Produkt itenıs (Produkt):

Items die inhoudelijk en in eerste instantie gerelateerd zijn aan de interpretatie van een vaardigheid. 


\section{Procedure}

Drie getrainde beoordelaars deelden alle items in twee categorieèn in (één van de dimensie Motorisch/Cognitief en één van de dimensie Proces/Produkt). De overeenstemming tussen de drie beoordelaars bleek acceptabel (kappa=.71). Naderhand werden de verschillen tussen de beoordelaars besproken. Dit leidde alsnog tot een definitieve toekenning van één van de categorieën aan de desbetreffende items.

Desondanks stuitte het toekennen van categorieën in de praktijk op twee problemen. In de eerste plaats bleek het soms moeilijk een onderscheid te maken tussen proces en produkt items. Dit kwam met name doordat enerzijds sommige items erg ruim geformuleerd waren zodat ze zowel proces alsook produktmatige aspecten bevatten (bijvoorbeeld: "komt op basis van de juiste handelingen tot de juiste conclusie"), anderzijds doordat sommige produktitems binnen een groter geheel ook procesitems kunnen zijn afhankelijk van het niveau waarop men beoordeelt (bijvoorbeeld "vergelijkt de reflexen links en rechts" kan een onderdeel van het proces in het toepassen van de vaardigheid zijn. maar kan ook op een uitkomst duiden). Dit type items dat in meerdere categorieën was in te delen is als "mengvorm" wel meegenomen in de berekeningen maar niet expliciet vermeld bij de tabellen (uitgezonderd overzichtstabel 2), aangezien ze inhoudelijk op meerdere manieren te interpreteren waren. Het betreft 205 items van het vierde studiejaar (22\% van het totaal) en 203 items van het zesde studiejaar (17\% van het totaal).

In de tweede plaats leidde de toepassing van de categorieën bij nader inzien tot de conclusie dat het label motorisch produkt niet bestaat. Het komen tot een bepaald produkt vereist volgens de definitie deels interpretatie. Het interpreteren is altijd een cognitieve activiteit aan het eind van een handeling.

Stations met drie of minder items binnen eén bepaalde categorie zijn vervallen binnen die categorie (kunnen dus nog wel binnen andere categorieën voorkomen). Dit heeft betrekking op 10 items (ongeveer $1 \%$ van het totaal aantal items) van de vierdejaars toets en 8 items (minder dan $1 \%$ van het totaal aantal items) van de zesdejaars toets. Het verwijderen van deze items leek zinvol omdat ondermeer betrouwbaarheidsanalyses gebaseerd op deze aantallen items nauwelijks betekenis hebben.

Items die in de oorspronkelijke toets vervielen om inhoudelijke redenen zijn ook niet meegenomen in de berekening. Voor alle circuits samen 
waren dat voor de vierdejaars toets, 135 items (14\% van het totaal) waarvan er alleen al 100 vervielen voor het domein sociale vaardigheden omdat de rol die de (simulatie)patiënt speelde niet toepasbaar was op een aantal onderdelen van de beoordelingslijst. Voor de zesdejaars toets bedroeg het aantal vervallen items in totaal 78 , waarvan 60 items van het domein kindergeneeskunde doordat er een compleet station in de toets moest vervallen op basis van commentaren na de toets.

In eerste instantie zijn de te onderzoeken deeltoetsen (itemtypologieën) beschreven in termen van beschrijvende statistiek. Voor de diverse categorieën werden apart en in combinatie met elkaar gemiddelde goed scores, standaarddeviaties over de totale toets en onderlinge correlationele verbanden berekend.

De stabiliteit van de categorieën werd onderzocht door analyse van de reproduceerbaarheid van scores.

Voor elke categorie werden totaalscores per station berekend. Deze vormden de basis voor de betrouwbaarheidsschatting. Voor elke categorie werd een "random effects personen x stations" ANOVA uitgevoerd ( $\mathrm{p} \times \mathrm{i}$ design) en werden variantiecomponenten geschat voor personen, stations en error. Hierbij zijn de variantiecomponenten van de categorieën van alle circuits per jaargroep bij elkaar opgeteld en gemiddeld. Deze componenten werden gebruikt voor de berekening van de reproduceerbaarheid van scores uitgaande van een norm- (generaliseerbaarheidscoëfficiënt) en domeingeoriënteerd (dependabilitycoëfficiënt) perspectief.

De mate waarin de diverse categorieèn tot andere kwalificaties in termen van zak/slaag beslissingen leiden ten opzichte van uitslagen van de reguliere vaardigheidstoets is onderzocht door aan de scores die studenten op de diverse categorieën behalen kwalificaties toe te kennen. Hierbij zijn scores groter en gelijk aan $70 \%$ als voldoende aangemerkt en scores beneden de $70 \%$ als niet voldoende. Deze grenzen komen overeen met de normen die in de meeste gevallen aan reguliere toetsen en bovendien aan alle herkansingstoetsen voor vaardigheden worden gesteld. 


\section{Resultaten}

In tabel 1 is het aantal circuits, aantal stations en het aantal items van de vierde- en zesdejaars toets weergegeven. De verdeling van het aantal items over circuits is redelijk stabiel. Zoals reeds eerder aangegeven bestond de zesdejaars toets uit paarsgewijs vrijwel identieke circuits zodat daar een aanzienlijke reductie van het aantal items plaatsvond.

Tabel 1: Aantal circuits, aantal stations en aantal items van de vierde en zesdejaars toets cursusjaar $87 / 88$.

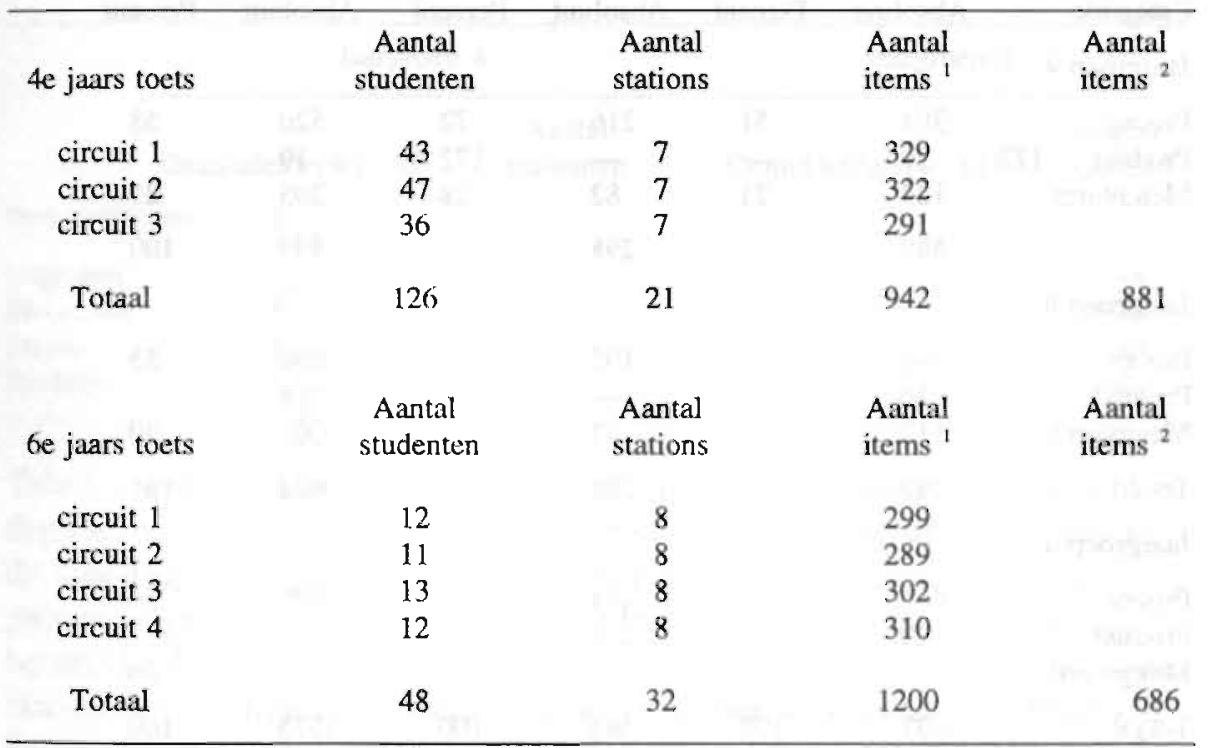

Niet gecorrigeerd voor stations die in meerdere circuits voorkomen

${ }^{2}$ Gecorrigeerd voor stations die in meerdere circuits voorkomen

In tabel 2 zijn de aantallen items per categorie aangegeven voor de onderzochte jaargroepen apart en samen. Hieruit blijkt dat het aantal procesitems aanzienlijk groter is dan het aantal produktitems. Voor het vierde studiejaar ligt de verhouding proces / produkt op 520 ten opzichte van 172 (verhouding 3:1). Voor het zesde studiejaar is de verhouding proces/ produkt 356 ten opzichte van 119 (verhouding 3:1). In totaal bevatten beide toetsen samen 876 procesitems en 291 produktitems. In het vierde studiejaar zijn er 593 cognitieve items ten opzichte van 298 
motorische items. In het zesde studiejaar is die verhouding 392 items met een cognitief karakter en 286 items met motorische kenmerken. In totaal over beide toetsen heen is de verdeling 965 cognitieve items en 584 motorische items. Beide jaargroepen vertonen dezelfde trend ten aanzien van de verdeling van categorieën over items.

Tabel 2: Aantal items per categorie uitgesplitst per jaargroep en som van de jaargroepen per categorie (absoluut en procentueel).

\begin{tabular}{|c|c|c|c|c|c|c|}
\hline \multirow{3}{*}{$\begin{array}{l}\text { Categorie } \\
\text { Jaargroep } 4\end{array}$} & \multicolumn{2}{|c|}{ Cognitief } & \multicolumn{2}{|c|}{ Motorisch } & \multicolumn{2}{|c|}{ Totaal } \\
\hline & \multirow[t]{2}{*}{ Absoluut } & \multirow[t]{2}{*}{ Percent } & \multirow[t]{2}{*}{ Absoluut } & \multirow[t]{2}{*}{ Percent } & \multirow[t]{2}{*}{ Absoluut } & \multirow[t]{2}{*}{ Percent } \\
\hline & & & & & & \\
\hline Proces & 304 & 51 & 216 & 72 & 520 & 58 \\
\hline Produkt $\quad 172$ & 29 & - & - & 172 & 19 & \\
\hline Mengvorm & 123 & 21 & 82 & 28 & 205 & 23 \\
\hline Totaal & 599 & 101 & 298 & 100 & $897^{1}$ & 100 \\
\hline \multicolumn{7}{|l|}{ Jaargroep 6} \\
\hline Proces & 161 & 41 & 195 & 68 & 356 & 53 \\
\hline Produkt 119 & 30 & - & - & 119 & 18 & \\
\hline Mengvorm & 112 & 29 & 91 & 32 & 203 & 30 \\
\hline Totaal & 392 & 100 & 286 & 100 & $678^{1}$ & 101 \\
\hline \multicolumn{7}{|c|}{ Jaargroep 4 en 6} \\
\hline Proces & 465 & 47 & 411 & 70 & 876 & 56 \\
\hline Produkt $\quad 291$ & 29 & - & - & 291 & 18 & \\
\hline Mengvorm & 235 & 24 & 173 & 30 & 408 & 26 \\
\hline Totaal & 991 & 100 & 584 & 100 & $1575^{1}$ & 100 \\
\hline
\end{tabular}

${ }^{1}$ Stations met dric of minder items per categorie zijn niet meegenomen in de berekening.

De gemiddelde scores en bijbehorende standaarddeviaties voor de oorspronkelijke toets en voor de diverse beoordelingscategorieën apart is weergegeven in tabel 3 . Hierbij blijkt dat voor beide studiejaren geldt dat de hoogste gemiddelde waarden bereikt worden bij de categorieën motorisch en proces. De laagste gemiddelde waarden worden bereikt bij de produktitems. Het niveau van de diverse beoordelingscategorieën is voor beide jaargroepen ongeveer gelijk.

De spreiding bij de produktitems is groter dan bij alle andere items. Dit kitn mogelijk worden verklaard doordat deze categorie de minste items 
bevat, waardoor minder stabiele, meer fluctuerende scores worden verkregen. Ook het gegeven dat dit net de (inhoudelijk) moeilijke items zijn, waardoor grotere verschillen optreden tussen de betere en de minder goede student, kan een rol spelen. De verschillen tussen cognitieve en motorische items zijn voor beide jaargroepen significant (student t-test; $p$ $\leq .01$ ); dit is eveneens het geval bij de verschillen tussen produktgerichte en procesgerichte items ( $\mathrm{p} \leq .001)$.

Tabel 3: De gemiddelde procentuele scores en bijbehorende standaarddeviaties (SD) voor de diverse categorieën afzonderlijk voor jaargroep $4(N=126)$ en jaargroep $6(N=48)$.

\begin{tabular}{|c|c|c|c|c|c|c|}
\hline & \multicolumn{3}{|c|}{ Jaargroep 4} & \multicolumn{3}{|c|}{ Jaargroep 6} \\
\hline Gen & hiddelde(\%) & $\mathrm{SD}$ & $\begin{array}{c}\text { Aantal } \\
\text { studenten }\end{array}$ & Gemiddelde $(\%)$ & $\mathrm{SD}$ & $\begin{array}{c}\text { Aantal } \\
\text { studenten }\end{array}$ \\
\hline Reguliere toets & 78.9 & 7.7 & 126 & 83.3 & 6.4 & 48 \\
\hline Cognitief & 77.9 & 8.9 & 126 & 80.8 & 6.7 & 48 \\
\hline Motorisch & 81.5 & 8.9 & 126 & 85.8 & 6.9 & 48 \\
\hline Proces & 81.5 & 8.8 & 126 & 85.5 & 6.9 & 48 \\
\hline Produkt & 76.4 & 9.7 & 126 & 77.1 & 9.7 & 48 \\
\hline
\end{tabular}

Tabel 4 geeft de gemiddelde scores en standaarddeviaties weer voor de diverse combinaties van categorieën. Dit zijn items die enerzijds zowel de labeling motorisch of cognitief hebben en anderzijds de labeling proces of produkt. Ook hier lijken de trends in beide jaargroepen hetzelfde. Proces items worden beter uitgevoerd dan produkt items zowel binnen het cognitieve domein alsook het motorische domein. Motorische items met een procesmatig karakter laten een hoger gemiddelde zien dan vergelijkbare cognitieve items voor beide jaargroepen. 
Tabel 4: De gemiddelde procentuele scores en bijbehorende standaarddeviaties (SD) van de categorieën Cognitief Proces, Cognitief Produkt, Motorisch Proces in jaargroep $4(N=126)$ en $6(N=48)$.

\begin{tabular}{lcccccccc}
\hline & \multicolumn{3}{c}{ Jaargroep 4} & & \multicolumn{3}{c}{ Jaargroep 6 } \\
\cline { 2 - 4 } \cline { 6 - 8 } \cline { 6 - 8 } & & Gemiddelde(\%) & SD & $\begin{array}{c}\text { Aantal } \\
\text { studenten }\end{array}$ & & Gemiddelde(\%) & SD & $\begin{array}{c}\text { Aantal } \\
\text { studenten }\end{array}$ \\
Cognitief Proces & 79.9 & 10.2 & 126 & & 84.4 & 9.3 & 48 \\
Cognitief Produkt & 75.8 & 10.2 & 126 & & 76.3 & 9.3 & 48 \\
Motorisch Proces & 85.1 & 8.8 & 126 & & 89.2 & 6.6 & 48 \\
\hline
\end{tabular}

\section{Relatie tussen de diverse categorieën en de kwalificaties van studenten}

Om na te kunnen gaan in hoeverre inhoudelijk anders gedefinieerde categorieën zouden leiden tot andere zak/slaag beslissingen, zijn overzichtstabellen gemaakt van alle categorieën met de bijbehorende toetsscores voor de twee onderzochte jaargroepen (tabel 5). Hierbij werd een gemiddelde score over alle stations boven de zeventig procent als voldoende werd beschouwd en een gemiddelde score over alle stations lager dan $70 \%$ als onvoldoende. Deze tabel overziende kan men inderdaad stellen dat sommige categorieën items zeker invloed hebben op de mate van zakken en slagen. Conform de waarnemingen van observatoren blijken produktitems het slechtste resultaat op te leveren. Strijdig met de verwachting is dat items met motorische kenmerken het gemakkelijkst lijken. De items waar observatoren veel moeite mee hebben, namelijk de items die uit het hoofd geleerd kunnen worden en simpelweg worden "opgedreund" blijken inderdaad gemakkelijker te zijn dan de produktitems, maar niet zo makkelijk als de items met motorische kenmerken. 
Tabel 5: Overzicht van zak/slaag beslissingen (absoluut en procentueel) behaald op items van de diverse categorieën in vergelijking met zak/slaag beslissingen van het totale toetsresultaat op de vaardigheidstoets voor vierde en zesdejaars studenten.

$\begin{array}{lll}\text { Categorie } & \text { Absoluut } & \text { Procentueel }\end{array}$

Jaar 4

Onvold Vold Aantal Onvold Vold Totaal

Totale toets

11

115

126

9

91

100

Cognitieve items

Motorische items

Proces items 22

Produkt items 35

$\begin{array}{ll}105 & 126 \\ 115 & 126\end{array}$

17

83

100

$\begin{array}{lll}6 & 115 & 126\end{array}$

5

95

100

17

100

$91 \quad 126$

28

100

Jaar 6 Totale toets

Cognitieve items

2

46

48

4

72

100

Motorische items

Proces items

Produkt items

43

48

10

96

100

$47 \quad 48$

$\begin{array}{ll}44 & 48\end{array}$

2

90

100

$37 \quad 48$

8

98

11

23

92

100

Tabel 6: Aantal stations per beooordelingscategorie van de vierde-en zesdejaars toets voor de hoofdcategorieën Cognitief, Motorisch, Proces, Produkt en combinaties van categorieën namelijk Cognitief Proces, Cognitief Produkt en Motorisch Proces.

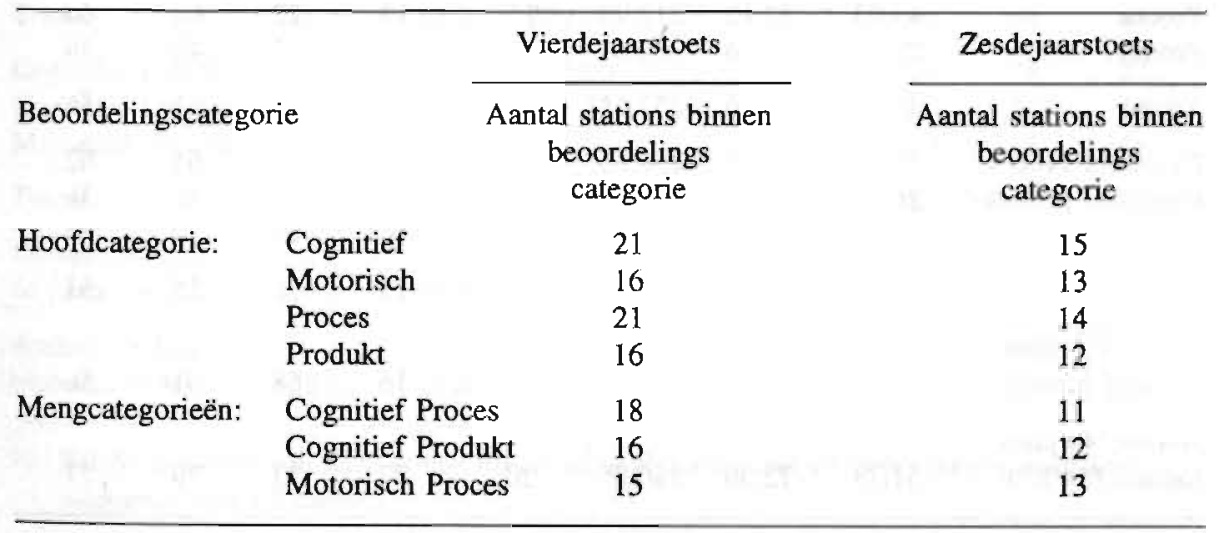

Dit beeld blijkt consistent te zijn voor beide jaargroepen. Dit betekent dat inhoudelijke veranderingen binnen de vaardigheidstoets in de door de makers gewenste richting, namelijk meer richten op produktmeting in de hogere jaargroepen ertoe zal leiden dat er meer studenten zijn die niet aan de norm van de toets voldoen. 
Betrouwbaarheid van de categorieën

Bij de berekening van de betrouwbaarheid zijn stations die twee maal voorkomen en stations met drie of minder items niet meegenomen in de berekeningen. Tabel 6 geeft een overzicht van het aantal stations waarop de nu volgende berekeningen zijn gebaseerd. Hierbij is gekeken naar de categorieën afzonderlijk en combinaties van categorieën. Beide jaargroepen laten met betrekking tot de verdeling van de stations over de verschillende beoordelingscategorieën ongeveer hetzelfde beeld zien. Het aantal stations met Cognitieve en Procesmatige items komt het meeste voor bij beide jaargroepen. Stations met produktmatige items het minst.

Tabel 7: Variantiecomponenten, generaliseerbaarheidscoëfficiënten en dependability coëfficiënten van het vierde studiejaar voor de hoofdcategorieën Cognitief, Motorisch, Proces, Produkt en voor een combinatie van de categorieën Cognitief Proces, Cognitief Produkt, Motorisch Proces afzonderlijk en totaal.

\begin{tabular}{|c|c|c|c|c|c|c|c|c|}
\hline \multirow[b]{3}{*}{ 4e studiejaar } & \multirow{2}{*}{\multicolumn{3}{|c|}{$\begin{array}{c}\text { Geschatte } \\
\text { variantiecomponenten }\end{array}$}} & \multirow{2}{*}{\multicolumn{3}{|c|}{$\begin{array}{l}\text { Percentage van } \\
\text { totale variantie }\end{array}$}} & \multicolumn{2}{|c|}{ G-coëff D-coëff } \\
\hline & & & & & & & $10^{1}$ & $10^{1}$ \\
\hline & Personen & Stations & Error & Personen & Stations & Error & G-10 & D-10 \\
\hline Cognitief & 47.51 & 35.08 & 232.33 & 15 & 11 & 74 & .67 & .63 \\
\hline Motorisch & 39.21 & 90.21 & 225.30 & 11 & 25 & 64 & .63 & .55 \\
\hline Proces & 45.03 & 37.12 & 211.90 & 15 & 13 & 72 & .68 & .64 \\
\hline Produkt & 26.37 & 45.84 & 360.89 & 6 & 11 & 83 & .42 & .39 \\
\hline Totaal & 39.53 & 52.06 & 257.61 & 11 & 15 & 74 & .61 & .56 \\
\hline Cognitief Proces & 49.33 & 35.02 & 258.85 & 14 & 10 & 75 & .65 & .62 \\
\hline Cognitief Produkt & 26.37 & 45.84 & 360.89 & 6 & 11 & 83 & .42 & .39 \\
\hline Motorisch Proces & 47.91 & 71.44 & 321.26 & 11 & 16 & 73 & .59 & .54 \\
\hline Totaal & 40.40 & 52.43 & 326.20 & 10 & 13 & 78 & .55 & .51 \\
\hline $\begin{array}{l}\text { Oorspronkelijke } \\
\text { 4e jaars toets }\end{array}$ & 41.29 & 43.60 & 183.14 & 15 & 16 & 68 & .61 & .56 \\
\hline $\begin{array}{l}\text { Andere } 4 \mathrm{e} \text { jaars } \\
\text { toetsen }(84-87)\end{array}$ & 51.73 & 72.59 & 140.85 & 20 & 27 & 53 & .79 & .71 \\
\hline
\end{tabular}

Bij de bepaling van deze generaliseerbaarheidscoëfficiënt en dependabilitycoëfficiënt is uitgegaan van 10 stations.

Stations gekenmerkt door combinaties van items behorende tot de categorieën Cognitief Proces. Cognitief Produkt en Motorisch Proces zijn ongeveer even sterk gerepresenteerd binnen de beide toetsen. Het 
absolute aantal stations is bij de vierdejaars toets groter dan bij de zesdejaaars.

De tabellen 7,8 en 9 laten de variantiecomponenten zien van de hoofdcategorieën apart en combinaties van categorieën. Ter vergelijking zijn de variantiecomponenten van de oorspronkelijke vierde en zesdejaars toets (curriculum 87/88) opgenomen samen met de gemiddelde variantiecomponenten van de toetsen in de periode 1984-87 (Van der Vleuten, 1989-C).

Tabel 8: Variantiecomponenten, generaliseerbaarheidscoëfficiënten en dependability coëfficiënten van het zesde studiejaar voor de hoofdcategorieën Cognitief, Motorisch, Proces, Produkt en voor een combinatie van de categorieën Cognitief Proces, Cognitief Produkt, Motorisch Proces afzonderlijk en totaal.

\begin{tabular}{|c|c|c|c|c|c|c|c|c|}
\hline \multirow[b]{2}{*}{ 6e studiejaar } & \multicolumn{3}{|c|}{$\begin{array}{c}\text { Geschatte } \\
\text { variantiecomponenten }\end{array}$} & \multicolumn{3}{|c|}{$\begin{array}{l}\text { Percentage van } \\
\text { totale variantie }\end{array}$} & \multirow{2}{*}{$-\frac{10^{1}}{G-10}$} & \multirow{2}{*}{$\begin{array}{c}\text { D-coëff } \\
\frac{10^{1}}{D-10}\end{array}$} \\
\hline & Personen & Stations & Error & Personen & Stations & Error & & \\
\hline Cognitief & 23.20 & 68.91 & 162.27 & 9 & 27 & 64 & .58 & .50 \\
\hline Motorisch & 18.79 & 117.07 & 170.23 & 8 & 38 & 55 & .52 & .39 \\
\hline Proces & 21.40 & 43.76 & 158.75 & 10 & 20 & 71 & .57 & .51 \\
\hline Produkt & 33.85 & 115.11 & 346.52 & 7 & 23 & 70 & .49 & .42 \\
\hline Totaal & 24.31 & 86.21 & 209.44 & 8 & 27 & 65 & .54 & .45 \\
\hline Cognitief Proces & 59.85 & 31.01 & 185.00 & 22 & 11 & 67 & .76 & .73 \\
\hline Cognitief Produkt & 33.85 & 115.11 & 226.32 & 9 & 31 & 60 & .55 & .47 \\
\hline Motorisch Proces & 21.42 & 133.96 & 342.28 & 4 & 27 & 69 & .38 & .31 \\
\hline Totaal & 31.93 & 171.93 & 255.08 & 7 & 37 & 56 & .55 & .42 \\
\hline $\begin{array}{l}\text { Oorspronkelijke } \\
\text { 6e jaars toets }\end{array}$ & 19.64 & 79.51 & 145.24 & 8 & 33 & 59 & .48 & .37 \\
\hline $\begin{array}{l}\text { Andere } 6 \mathrm{e} \text { jaars } \\
\text { toetsen }(84-87)\end{array}$ & 68.13 & 92.08 & 151.95 & 22 & 29 & 49 & .82 & .74 \\
\hline
\end{tabular}

Bij de bepaling van deze generaliseerbaarheidscoëfficiënt en dependabilitycoëfficiënt is uitgegaan van 10 stations. 
Zowel voor het vierde als voor het zesde studiejaar blijkt voor wat betreft de hoofddimensies de persoonscomponent van de produktitems het kleinst. Deze items zijn klaarblijkelijk minder goed dan andere items in staat personen van elkaar te onderscheiden. Bij de hoofddimensies geldt eveneens dat de stationscomponent voor de motorische items het grootst is voor het vierde en zesde studiejaar. De variabele inhoud van een station heeft dus relatief de meeste invloed op dit type items.

Voor de mengvormen van de verschillende dimensies geldt dat items met het label cognitief produkt een lage persoonscomponent kunnen hebben (4e jaar) ofwel een hoge stationscomponent (6e jaar). Dit betekent dat individuele verschillen tussen studenten een minder belangrijke rol spelen (4e jaar), dan wel dat de inhoud van stations belangrijker is bij het verklaren van verschillen tussen studenten (6e jaar).

Tabel 9: Variantiecomponenten, generaliseerbaarheidscoëfficiënten en dependability coëfficiënten van het vierde en zesde studiejaar samen voor de hoofdcategorieën Cognitief, Motorisch, Proces, Produkt en voor een combinatie van de categorieën Cognitief Proces, Cognitief Produkt, Motorisch Proces afzonderlijk en totaal.

\begin{tabular}{|c|c|c|c|c|c|c|c|c|}
\hline \multirow[b]{2}{*}{$4 \mathrm{e}$ en $6 \mathrm{e}$ studiejaar } & \multicolumn{3}{|c|}{$\begin{array}{c}\text { Geschatte } \\
\text { variantiecomponenten }\end{array}$} & \multicolumn{3}{|c|}{$\begin{array}{l}\text { Percentage van } \\
\text { totale variantie }\end{array}$} & \multirow{2}{*}{$\begin{array}{c}\text { G-coëff } \\
\frac{10^{1}}{G-10}\end{array}$} & \multirow{2}{*}{ 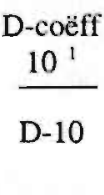 } \\
\hline & Personen & Stations & Error & Personen & Stations & Error & & \\
\hline Cognitief & 40.80 & 44.41 & 213.00 & 14 & 15 & 71 & .65 & .61 \\
\hline Motorisch & 33.58 & 97.62 & 210.11 & 10 & 29 & 61 & .61 & .52 \\
\hline Proces & 38.51 & 38.95 & 197.24 & 14 & 14 & 72 & .66 & .61 \\
\hline Produkt & 28.43 & 64.95 & 356.92 & 6 & 18 & 76 & .44 & .40 \\
\hline Totaal & 35.33 & 61.48 & 244.32 & 10 & 18 & 72 & .59 & .49 \\
\hline Cognitief Proces & 52.23 & 33.91 & 238.48 & 16 & 10 & 74 & .68 & .65 \\
\hline Cognitief Produkt & 28.43 & 64.95 & 334.80 & 7 & 15 & 78 & .45 & .41 \\
\hline Motorisch Proces & 40.60 & 88.89 & 327.06 & 9 & 19 & 72 & .55 & .49 \\
\hline Totaal & 38.06 & 85.40 & 306.58 & 9 & 20 & 71 & .55 & .49 \\
\hline
\end{tabular}

Bij de bepaling van deze generaliseerbaarheidscoëfficiënt en dependabilitycoëfficiënt is uitgegaan van 10 stations.

Items met het label cognitief proces lijken het beste studenten te kunnen onderscheiden en hebben eveneens een lage stationscomponent. Items met dit label lijken relatief beter in staat dan de andere items om betrouwbaarder beslissingen over studenten te nemen. Dit uit zich ook in 
de relatief hoge generaliseerbaarheids- en dependabilitycoëfficiënten, zoals vermeld in de tabellen 7 en 8 , uitgaande van een toets van tien stations. In tabel 9 zijn de gegevens van de beide studiejaren bij elkaar opgeteld en bevestigen daarmee bovenstaande uitspraken, doordat de generaliseerbaarheids- en dependabilitycoëfficiënten relatief hoog blijven. Bovenstaande betekent dat veranderingen in de vaardigheidstoets in de door observatoren gewenste richting namelijk meer produktgericht meten, waarschijnlijk een verlagend effect heeft op de betrouwbaarheid.

\section{Validiteit}

Om na te gaan in hoeverre gemeenschappelijke dan wel differentiële aspecten worden gemeten door de verschillende categorieën zijn de onderlinge correlationele verbanden nagegaan. De tabellen 10 en 11 geven hiervan een overzicht.

Tabel 10: Correlationele verbanden tussen de hoofdcategorieën Cognitief, Motorisch, Proces, Produkt en voor een combinatie van de categorieën Cognitief Proces, Cognitief Produkt, Motorisch Proces van het vierde studiejaar.

\begin{tabular}{lccccccc}
\hline & Cognitief & Motorisch & Proces & Produkt & \multicolumn{2}{c}{$\begin{array}{c}\text { Cognitief } \\
\text { Proces }\end{array}$} & $\begin{array}{c}\text { Cognitief Motorisch } \\
\text { Produkt Proces }\end{array}$ \\
Cognitief & - & & & & & & \\
Motorisch & $.67^{* *}$ & - & & & & \\
Proces & $.86^{* *}$ & $.78^{* *}$ & - & & & \\
Produkt & $.81^{* *}$ & $.54^{* *}$ & $.60^{* *}$ & - & & \\
Cognitief Proces & & & & - & & \\
Cognitief Produkt & & & & $.57^{* *}$ & - & \\
Motorisch Proces & & & & $.58^{* *}$ & $.51^{* *}$ & - \\
\hline
\end{tabular}

${ }_{* *}^{*} \mathrm{p} \leq .005$

De gevonden correlaties in de tabellen 10 en 11 zijn alle matig tot hoog en significant. De hoofdeffecten apart lijken iets hoger met elkaar te correleren dan de combinatie van effecten. Categorieën die op grond van inhoudelijke kenmerken van elkaar verschillen zoals Proces en Produkt of Motorisch en Cognitief blijken sterk met elkaar te correleren. 
Tabel 11: Correlationele verbanden tussen de hoofdcategorieën Cognitief, Motorisch, Proces, Produkt en voor een combinatie van de categorieën Cognitief Proces, Cognitief Produkt, Motorisch Proces van het zesde studiejaar.

\begin{tabular}{|c|c|c|c|c|c|c|}
\hline & Cognitief & Motorisch & Proces & $\begin{array}{r}\text { Produkt Cognitief } \\
\text { Proces }\end{array}$ & $\begin{array}{r}\text { Cognitief } \\
\text { Produkt }\end{array}$ & $\begin{array}{c}\text { Motorisch } \\
\text { Proces }\end{array}$ \\
\hline Cognitief & - & & & & & \\
\hline Motorisch & $.66^{* * *}$ & - & & & & \\
\hline Proces & $.68 * *$ & $.88 * *$ & - & & & \\
\hline Produkt & $.66^{* *}$ & $.28^{*}$ & .21 & - & & \\
\hline Cognitief Proces & & & & 一 & & \\
\hline Cognitief Produkt & & & & $.28 *$ & 一 & \\
\hline Motorisch Proces & & & & $.52^{* *}$ & $.31^{* *}$ & - \\
\hline
\end{tabular}

$*=\mathrm{p} \leq .005$

$* *=p \leq .001$

De enige uitzondering hierop zijn de categorieën Proces en Produkt bij de zesdejaars toets, zoals te zien is in tabel 11. De gevonden correlaties in tabellen 10 en 11 suggereren op zijn minst dat de verschillen in meetinformatie tussen de categorieën niet zo groot zijn als men op grond van de inhoudelijke onderverdeling mocht verwachten.In tabel 12 worden de onderlinge correlaties aangegeven tussen de diverse categorieën en de resultaten van een algemene medische kennistoets, de voortgangstoets. Op grond van de inhoudelijke kenmerken van items zou men een grotere samenhang mogen verwachten tussen de meer cognitieve items en de voortgangstoets en een minder grote samenhang tussen de meer motorische items en de voortgangstoets. Hierbij zijn de resultaten van die voortgangstoets genomen die het dichtst lag bij het moment van toetsafname van de vaardigheidstoets. Door een administratieve oorzaak bleken de correlaties van de hoofdeffecten met de voortgangstoetsgegevens na het onderzoek niet meer beschikbaar zodat hier alleen de resultaten vermeld staan van de correlaties tussen de gecombineerde hoofdeffecten en de voortgangstoets.

Bij de vierdejaars toets is er geen verschil te zien tussen de correlationele verbanden van meer cognitief gerichte items en meer motorisch gerichte items in relatie tot de resultaten op de voortgangstoets. $\mathrm{Bij}$ de zesdejaars toets lijken cognitieve items iets beter dan motorische items te correleren met voortgangstoetsresultaten. Toch lijkt er geen sprake van een systematisch verband tussen cognitief gerichte items en resultaten op de voortgangstoets. Samengevat kan men stellen dat de correlationele 
studies weinig steun geven aan de hypothese dat de verschillende inhoudsgebieden ook verschillende meetinformatie opleveren.

Tabel 12: Correlationele verbanden van de verschillende categorieën Cognitief Proces, Cognitief Produkt, Motorisch Proces, afzonderlijk en de regulier afgenomen vaardigheidstoets met de behaalde resultaten op een algemene medische kennistoets (voortgangstoets) voor de jaargroepen 4 en 6 apart en samen.

\begin{tabular}{cccc}
\hline & \multicolumn{3}{c}{ Voortgangstoets } \\
\cline { 2 - 4 } Categorie & Jaar 4 & Jaar 6 & Jaar 4 en 6 \\
Cognitief Produkt & .38 & .23 & .31 \\
Cognitief Proces & .39 & .29 & .41 \\
Motorisch Proces & .40 & .15 & .41 \\
Reguliere toets & .51 & .31 & .52 \\
\hline
\end{tabular}

\section{Discussie}

Op basis van de verwachtingen van observatoren zou er binnen de toets geen evenredige verdeling bestaan tussen items van de verschillende beschreven categorieën. Deze verschillen zouden dan leiden tot zak/slaag beslissingen waarbij sommige studenten mogelijk onterecht zouden slagen of zakken.

$\mathrm{Bij}$ de toetsen die in dit onderzoek betrokken zijn kan men stellen dat er van een evenwichtige samenstelling van items, voor zover dat betrekking heeft op het aantal items binnen categorieën, geen sprake is. Conform de verwachting is het aantal cognitieve items en items met een procesmatig karakter binnen één toets veruit in de meerderheid ten opzichte van de andere categorieën. Eveneens conform de verwachting worden items met een procesmatig karakter beter beantwoord (verricht) dan items die betrekking hebben op conclusies en bevindingen. Hoewel studenten ook bij de cognitieve items een hoge score behalen blijkt de score voor de motorische items toch nog hoger te zijn, hetgeen niet overeenkomt met de verwachting. Een mogelijke verklaring zou kunnen zijn dat het aantal 
motorische handelingen zo gedetailleerd is uitgewerkt dat vele van deze handelingen evenzeer uit het hoofd te leren zijn als de items met de cognitieve aspecten.

De categorie met de combinatie cognitieve en produktmatige items leidt tot een relatief lage score in beide jaargroepen, hoewel hier wel een verschil te zien is tussen het vierde en het zesde jaar. Dit lijkt met name het gevolg van het systematisch laag scoren van studenten op items met een produktmatig karakter. Dit bevestigt het beeld van observatoren dat studenten over het algemeen goed weten hoe een bepaalde vaardigheid verricht moet worden maar de verkregen gegevens in dat stadium van de studie nog niet in voldoende mate te interpreteren. Hierbij moet men wel bedenken dat het ook mogelijk is dat de verwachtingen vanuit docenten naar studenten misschien te hoog gesteld zijn.

Bovenstaande wordt nog eens bevestigd wanneer gekeken wordt naar de relatie tussen categorieën en zak/slaag percentages van studenten. Voor toetsen die zouden bestaan uit items met alleen een produktmatig karakter zouden veel meer studenten zakken dan voor toetsen die alleen zouden bestaan uit items met een motorisch karakter.

De betrouwbaarheidsstudies laten echter een tegengesteld beeld zien. Toetsen die bestaan uit items met een procesmatig karakter hebben in deze studie een hogere betrouwbaarheid dan items met een produktmatig karakter. Ten dele kunnen de betere betrouwbaarheidsresultaten voor procesmatige en cognitieve aspecten van de vaardigheidstoets verklaard worden door het feit dat de meeste items betrekking hebben op deze categorieën. Doordat de scores daarmee gebaseerd worden op meer informatie dan bij de andere categorieën zijn minder fluctuaties te verwachten en wordt de betrouwbaarheid verbeterd. Hoewel het moeilijk in te schatten is hoe groot de invloed hiervan is, lijkt het erop dat processnatige en cognitieve items een positieve invloed hebben op de betrouwbaarheid. Dit betekent dat wanneer het aantal procesmatige en cognitieve items wordt veranderd, rekening moet worden gehouden met een daling van de betrouwbaarheid, waardoor wellicht ter compensatie meer stations moeten worden aangeboden.

Wanneer gekeken wordt naar de onderlinge samenhang tussen de verschillende categorieèn valt op dat deze in het algemeen matig tot groot is. Dat was niet de verwachting aangezien de categorieën op grond van verschillende inhoud waren samengesteld. Alleen de items met produktmatige kenmerken hebben lage (in het zesde studiejaar) tot matige (in het vierde studiejaar) correlaties met de overige categorieën. Hierbij wordt wederom bevestigd dat items met produktmatige 
kenmerken niet alleen inhoudelijk maar ook meettechnisch andere informatie verschaffen.

Correlationele verbanden met een algemene medische kennistoets zijn laag. Dit suggereert dat items uit de verschillende categorieën zoals te verwachten andere meetinformatie opleveren. In tegenstelling tot de verwachting blijkt er geen sterker verband te zijn tussen de items van de vaardigheidstoets met kennisaspecten en de resultaten op de voortgangstoets.

Concluderend kan men stellen dat er inderdaad sprake is van een ongelijksoortige (inhoudelijke) verdeling van items binnen de vaardigheidstoets. Een tweede conclusie is dat de gewenste veranderingen binnen de vaardigheidstoets op basis van de kritiek van observatoren (zie hoofdstuk 4), waarschijnlijk zal leiden tot minder betrouwbare toetsuitslagen en in eerste instantie tot meer studenten die niet aan de norm voldoen. In de toekomst zal desalniettemin gestreefd moeten worden om in meer stations produktgericht te meten. Het "verlies" aan hetrouwbaarheid is mogelijk te compenseren door een geringere nadruk op procesgerichte meting, wat zou kunnen leiden tot een kortere stationsduur. Met een gelijkblijvende toetsduur wordt het dan mogelijk meer stations met verschillende inhoud aan te bieden. 


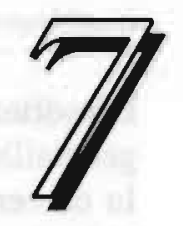

\section{EEN VERGELIJKING TUSSEN GLOBALE EN ANALYTISCHE BEOORDELINGEN}

\section{Inleiding}

In hoofdstuk 3 is uiteengezet hoe de blauwdruk van de vaardigheidstoets tot stand komt en op welke manier de inhoud van het onderwijs wordt gereflecteerd in de criterialijsten. Aangegeven is dat de te volgen stappen van het lichamelijk onderzoek in detail zijn vastgelegd volgens de "standaarden". Elke student behoort het onderzoek op de beschreven wijze te verrichten. Uiteraard zijn varianten mogelijk, maar er wordt in principe maar één manier onderwezen en getoetst. Achtergrond bij deze keuze is, dat geredeneerd vanuit het leerproces van de student, daar waar geen kennis (of vaardigheid) over een bepaald probleem bestaat, er eerst één juiste manier aangeleerd moet worden (de standaard) om een bepaald probleem op te lossen (bijvoorbeeld hoe onderzoek ik het hart). Vervolgens kan door de praktijkervaring blijken dat er meerdere manieren bestaan om een probleem aan te pakken.

Items van criterialijsten zijn in principe direct afleidbaar van de stappen in de standaard. Zodoende hebben criterialijsten ook een grote mate van detaillering gekregen en kan er gesproken worden van een analytisch oordeel.

Delen van dit hoofdstuk zijn eerder verschenen in: Van Luijk, S.J. \& Van der Vleuten, C.P.M. (1992) A comparison of checklists and rating scales in performance-based testing. In: Hart, I.R., Harden, R.M. (Eds.) Current developments in Assessing Clinical Competence. Montreal: Can-Heal Publications. 
Een drietal andere redenen lagen ten grondslag aan het invoeren van gedetailleerde criterialijsten.

In de eerste plaats bestond de opvatting dat gedetailleerde oordelen objectiever zouden zijn dan globale (Streiner, 1985). Bij meer gedetailleerde criterialijsten is de operationalisatie van de te meten vaardigheid specifieker zodat de observator duidelijker informatie wordt verschaft op grond waarvan hij een student beoordeelt. Duidelijkere informatie makt de interpretatievrijheid van de observator geringer en derhalve het oordeel objectiever.

Tevens speelde een rol dat studenten aan de hand van gedetailleerde criterialijsten veel duidelijker konden weten wat precies van ze verwacht werd. Door middel van criterialijsten worden onderwijsdoelstellingen zichtbaar gemaakt.

Een laatste belangrijk argument voor detaillering van criterialijsten betrof de mogelijkheid tot het verzamelen van gedetailleerde informatie over de student waardoor de kwaliteit van de feedback naar student en onderwijsprogramma geoptimaliseerd wordt.

Zoals uitvoerig in hoofdstuk 4 beschreven is leidt het afnemen van vaardigheidstoetsen op de door ons gekozen wijze tevens tot een aantal onbedoelde en onwenselijke effecten. Een deel van deze effecten is juist te wijten aan de grote mate van detaillering van criterialijsten. Binnen het kader van dit hoofdstuk is een aantal effecten te noemen.

In de eerste plaats wordt door deskundige beoordelaars de analytische beoordeling als een keurslijf ervaren en doet deze afbreuk aan de acceptabiliteit. Er wordt "slechts" geregistreerd of een student bepaalde handelingen verricht. De door de observator gevoelde discrepanties tussen de criterialijst en een subjectieve indruk kunnen niet in een beoordeling tot uitdrukking komen. Deze discrepanties ontstaan vaak doordat relatief veel items besteed worden aan minder belangrijke onderdelen van de handeling en essentiële items vaak minder zwaar wegen binnen een criterialijst (zie ook hoofdstuk 6).

In de tweede plaats leidt deze grote mate van detaillering tot het uit het hoofd leren van criterialijsten door de student die zich voorbereidt op een vaardigheidstoets. Transparantie leidt dus tot strategisch gedrag van studenten (Hofstee, 1985). De consequentie hiervan is dat dit in een toetssituatie meer leidt tot reproduktie van kennis dan tot zorgvuldig kijken, luisteren en onderzoeken van de patiënt.

In de derde plaats wordt de inhoudsvaliditeit van deze criterialijsten in hogere jaargroepen aangetast omdat in praktische situaties (co- 
assistentschappen) niet op een dergelijke systematische en gedetailleerde manier gewerkt wordt. In deze studiejaren moet ruimte zijn voor individuele variaties.

Tenslotte bestaat bij een sterke uitsplitsing van elementen van de vaardigheid het gevaar van trivialiteit van de inhoud hetgeen meestal negatief werkt op de validiteit. Bijvoorbeeld het klaarleggen van het materiaal voor onderzoek, de positie van de hand bij percussie van de buik, het aangeven hoe een injectiespuit moet worden vastgepakt, in het algemeen items met een procesmatig karakter worden met name in de hogere jaargroepen nogal eens als overbodige items gezien afgaande op de ervaring die de student heeft opgebouwd.

De gesignaleerde problemen zouden voor een deel kunnen worden opgelost door het meer globaal maken van de beoordelingscriteria. Meer globale criteria lenen zich minder goed voor het uit het hoofd leren en passen meer bij de gevolgde werkwijze in het praktisch medisch onderwijs (niet alle handelingen in detail uitvragen of verrichten daar waar men niets verwacht te vinden). Bovendien geeft globalisering van criterialijsten de observatoren een grotere vrijheid bij het beoordelen van studenten en wordt het "keurslijf" iets minder strak.

Uiteraard bevat dit laatste ook een gevaar. Globale oordelen zijn subjectiever en kunnen leiden tot grotere verschillen in beoordeling en derhalve tot verlaging van de betrouwbaarheid.

Er zijn weinig studies bekend die een directe vergelijking maken tussen globale en analytische criterialijsten bij observatietoetsen. Littlefield en Troendle (1987) komen tot de conclusie dat bij inhoudsdeskundige beoordelaars de combinatie van globale en gedetailleerde op resultaat gerichte beoordelingen leidt tot de hoogste toetsbetrouwbaarheid. Een studie verricht door Cohen e.a. (1990) geeft aan dat globale oordelen niet erg veel verschillen in betrouwbaarheid vertonen ten opzichte van gedetailleerde oordelen. Ook deze studie is verricht met inhoudsdeskundige beoordelaars.

Ook de bevindingen van Frijns (1993) laten zien dat de mate van structuur van criterialijsten vrijwel geen invloed heeft op de totale toetsbetrouwbaarheid. Er moet echter wel enige structuur zijn! 


\section{Probleemstelling}

Centraal in dit hoofdstuk staat de vraag in hoeverre globale oordelen over studenten andere informatie opleveren dan gedetailleerde criterialijsten. Kortweg betekent dit dat de betrouwbaarheid en de validiteit van de globale beoordelingsschalen onderzocht moet worden. De betrouwbaarheidsstudies zijn met name gericht op de vraag of de veronderstelde subjectiviteit van de globale criterialijsten en de objectiviteit van de gedetailleerde criterialijsten direct gerelateerd zijn aan de betrouwbaarheid. Betrouwbaarheid en objectiviteit/subjectiviteit zijn niet noodzakelijkerwijs gelijksoortige begrippen (Van der Vleuten et al., 1991; Norman et al., 1991). In de literatuur worden doorgaans lagere betrouwbaarheden gerapporteerd voor meer globale beoordelingsvormen dan voor analytische beoordelingsvormen (Streiner, 1985), maar gewoonlijk zijn deze vergelijkingen alleen gebaseerd op overeenstemming tussen beoordelaars. De beoordelaarsbetrouwbaarheid als (enige) criterium vormt echter geen faire vergelijking. De betrouwbaarheid van scores verkregen met een meetinstrument wordt bepaald door een veelheid aan factoren of foutenbronnen en daarvan is de overeenstemming tussen beoordelaars er slechts één.

Een betere vergelijking van de betrouwbaarheid tussen globale en analytische oordelen is mogelijk door de totale toetsbetrouwbaarheid als criterium te nemen. Zeker in het geval van de vaardigheidstoetsen is dat adequater, omdat zich bij elk station een andere observator bevindt en het eindoordeel over een student tot stand komt door een veelvoud aan beoordelaars (evenveel als er stations zijn). Ruis geïntroduceerd door een lage overeenkomst tussen observatoren op één station kan bij vergelijking over meerdere stations een geheel andere betekenis krijgen. Verwacht kan dus worden dat de interbeoordelaarsbetrouwbaarheid van globale oordelen lager zal uitvallen dan voor de analytische oordelen, maar de vraag is of en in welke mate de totale betrouwbaarheid van beide beoordelingsvormen verschilt.

Wat betreft de validiteitsverschillen tussen beide beoordelingsvormen kunnen verschillende vragen worden gesteld.

Een eerste validiteitsaspect betreft de verschillen in gemiddelde waardering. Observatoren melden vaak dat de criterialijst de student bevoordeeld ten opzichte van hun eigen subjectieve oordeel, omdat alle punten vaak ongewogen in de beoordeling betrokken worden. Op grond hiervan zou verwacht worden dat de uitslagen van het globale oordeel in 
de regel lager liggen dan dat van de criterialijst. Temeer daar het omgekeerde - het beoordelen van de student aan de hand van criterialijsten werkt in het nadeel van de student - minder vaak gehoord wordt. In principe zou deze trend onafhankelijk moeten zijn van de inhoud en te zien zijn over alle domeinen. De verwachting is dat de geringste verschillen tussen globale en analytische beoordeling zullen optreden bij de minst gedetailleerde criterialijsten, omdat criterialijst en globaal oordeel hier het meest op elkaar lijken. De grootste verschillen zullen optreden bij lijsten die zeer gedetailleerd zijn en/of vaak gebruikt zijn in eerdere toetssituaties. In het laatste geval zijn de beoordelingscriteria vaak bekend en kunnen ze derhalve leiden tot een hoge score door het "uit het hoofd leren" van oude criterialijsten.

Een tweede validiteitsvraag betreft de mate waarin beide beoordelingsvormen tot dezelfde rangordening van studenten komen. Gemiddelde verschillen of overeenkomsten laten de rangordening van studenten onverlet. Eventuele verschillen in algemeen niveau zouden kunnen worden opgevangen met aanpassingen in de cesuur van de vaardigheidstoets, maar wanneer de globale en analytische oordelen tot een andere rangordening van studenten zou leiden dan zou dat een ernstige bedreiging van de validiteit inhouden.

Een derde validiteitsvraag betreft min of meer een combinatie van beide voorgaande probleemstellingen. In hoeverre is de door de observatoren gepercipieerde discrepantie tussen hun eigen oordeel en dat van de criterialijst te verklaren. Dit kan enerzijds bekeken worden door vergelijking van de kenmerken van studenten die maximaal anders geclassificeerd worden door beide beoordelingsvormen en anderzijds door analyse van de correlationele patronen tussen scores van globaile oordelen en criterialijsten. Men zou kunnen veronderstellen dat discrepanties vooral veroorzaakt worden door andere zaken dan de techniek van de vaardigheid (waar de criterialijst zich met name op richt), zoals bijvoorbeeld attitude-aspecten.

Een vierde validiteitsaspect betreft de mate waarin scores op beide beoordelingsvormen voorspellend zijn voor een extern criterium. Op het tijdstip van dit onderzoek waren alleen scores op de voortgangstoets voorhanden als extern criterium. Wellicht dat voortgangstoetsresultaten een minder adequaat criterium vormen, maar eerder is aangetoond dat er substantiële correlaties bestaan tussen voortgangstoetsen en vaardigheids- 
toets, mogelijk als gevolg van de gedetailleerde criterialijsten (Van der Vleuten et al., 1989-B). De vraag betreft dus of en in welke mate scores verkregen met een globale beoordelingsvorm een ander correlatiepatroon opleveren dan scores verkregen met een analytische vorm. Over de interpretatie van mogelijke verschillen kan getwist worden, maar in eerste instantie is het vooral de vraag of er verschillen zijn die zouden duiden op kwalitatieve verschillen met betrekking tot de informatie van beide beoordelingsvormen.

Een laatste validiteitsvraag betreft de mate waarin er met globale beoordelingen andere besluiten worden genomen over studenten. Gezien de klacht van observatoren dat criterialijsten sommige studenten overwaarderen, zouden -afhankelijk van de cesuur- zak/slaagbeslissingen op grond van globale beoordelingen negatiever moeten uitvallen.

\section{Methode}

\section{Instrumenten}

Voor de globale beoordelingsvorm werd een keuze gemaakt voor een sterk geglobaliseerde beoordeling. Enerzijds zou dit eventuele effecten maximaliseren en anderzijds zou het daarmee mogelijk zijn de beoordeling toe te voegen aan de bestaande criterialijst zonder te veel tijd van de observator in beslag te nemen. De globale beoordelingslijst bestond uit twee delen: een beoordeling van de algemene indruk en een meer specifieke beoordeling op drie aspecten (het specifieke oordeel): een beoordeling van 1) de techniek van de vaardigheid, 2) de systematiek van de vaardigheid, en 3 ) de benadering van de patiënt. Elke beoordeling werd uitgedrukt in een cijfer van 0 tot 10 .

De analytische methode bestond uit de criterialijst van het betreffende station.

\section{Procedure}

De globale beoordelingen werden toegevoegd aan de criterialijsten van het studiejaar 1987/1988 in de toetsen van alle jaargroepen. De observatoren werden op de hoogte gebracht van de beoordeling en van 
de wenselijkheid van de invulling, maar werden niet specifiek getraind op dit aspect. Bovendien werd zowel aan observatoren als aan studenten uitdrukkelijk meegedeeld dat de resultaten van de globale oordelen niet zouden meetellen in een waardering voor de vaardigheidstoets.

De globale beoordelingen werden ingevuld nadat de criterialijst was ingevuld. Dit is een methodologisch onwenselijke situatie, omdat het globale oordeel gecontamineerd kan zijn door de invulling van de criterialijst. Om zicht te krijgen op dit effect werd een controleexperiment uitgevoerd, waarin een systematische vergelijking plaatsvond tussen gegevens van globale oordelen die ingevuld waren zonder of met voorafgaande invulling van de criterialijst. Het controle-experiment zal hieronder separaat worden beschreven.

Alle resultaten uit de zes vaardigheidstoetsen van het studiejaar $1987 / 1988$ werden in de analyse betrokken, waarbij geëist werd dat voor elke student een complete reeks dubbele beoordelingen (globaal en analytisch over alle stations) voorhanden was. Doordat lang niet alle observatoren globale oordelen invulden (facultatief) kwam een relatief groot aantal studentgegevens te vervallen. Van de oorspronkelijke 753 studenten resteerden er 490 , van de oorspronkelijke 40 domeinen bleven er 33 over, meer dan 5 per toets. Tabel 1 geeft een gedetailleerd overzicht.

Tabel 1: Vergelijking van het aantal stations en studenten welke participeerden in de reguliere vaardigheidstoetsen met de aantallen stations en studenten welke in de data-analyse zijn betrokken.

\begin{tabular}{|c|c|c|c|c|}
\hline \multirow[b]{2}{*}{ Jaar } & \multicolumn{2}{|c|}{$\begin{array}{c}\text { Oorspronkelijke } \\
\text { toets }\end{array}$} & \multicolumn{2}{|c|}{$\begin{array}{c}\text { Over na } \\
\text { uitval }\end{array}$} \\
\hline & $\begin{array}{c}\text { Aantal } \\
\text { studenten }\end{array}$ & $\begin{array}{c}\text { Gemiddeld aantal } \\
\text { stations }\end{array}$ & $\begin{array}{c}\text { Aantal } \\
\text { studenten }\end{array}$ & $\begin{array}{c}\text { Gemiddeld aantal } \\
\text { stations }\end{array}$ \\
\hline 1 & 144 & 8 & 93 & 8 \\
\hline 2 & 139 & 4 & 76 & 4 \\
\hline 3 & 115 & 10 & 63 & 7 \\
\hline 4 & 127 & 7 & 80 & 5 \\
\hline 5 & 117 & 8 & 88 & 6 \\
\hline 6 & 111 & 8 & 90 & 6 \\
\hline Totaal & 753 & & 490 & \\
\hline
\end{tabular}

Voor alle studenten werden per station scores berekend in percentages van maximaal te behalen punten voor zowel de criterialijsten als de 
globale oordelen. De globale oordelen werden uitgesplitst naar de twee onderdelen en aldus werd één score verkregen voor 'Algemene indruk' en 'Specifiek oordeel'. De totale toetsscore per student werd berekend door het gemiddelde te nemen van de stationsscores. In de stations waar sprake was van een co-observator waren dubbele analytische en dubbele globale beoordelingen voorhanden $(n=649)$. Dit aantal dubbele beoordelingen wijkt niet af van andere curriculumjaren.

\section{Statistische analyse}

Voor de betrouwbaarheidsstudies werd gebruik gemaakt van de generaliseerbaarheidsanalyse. De interbeoordelaarsbetrouwbaarheid werd geschat op grond van de aanwezige dubbele analytische en globale beoordelingen. Deze werden onderworpen aan een observatoren-genestbinnen-studenten ANOVA. Dit betekent dat bepaalde observatoren aan bepaalde studenten zijn toegewezen. Variantiecomponenten werden geschat en generaliseerbaarheidscoëfficiënten berekend (voor één beoordeling). Deze betrouwbaarheidsindex kan worden opgevat als een overeenstemmingsmaat tussen beoordelaars, waarbij zowel rangordeverschillen als absolute verschillen tussen beoordelaars zijn verdisconteerd.

Voor de schatting van de totale betrouwbaarheid werd per circuit van elke toets een studenten (personen) $\mathrm{x}$ stations ANOVA uitgevoerd ( $\mathrm{P} \mathrm{x}$ $S$ design; all random) en variantiecomponenten geschat. Deze werden per jaargroep gemiddeld (gewogen naar steekproefgrootte) over circuits heen en over jaargroepen heen voor een generale schatting. Vervolgens werd een tweetal betrouwbaarheidsindices berekend: de generaliseerbaarheidscoëfficiënt uitgaande van een norm-georiënteerd perspectief en dependability-coëfficiënten uitgaande van een domein-georiënteerd perspectief. In een norm-georiënteerde benadering hebben de scores een betekenis in relatie tot elkaar (bijvoorbeeld een studentscore behoort bij de $10 \%$ beste); in een domein-georiënteerde benadering wordt aan de scores een absolute betekenis gehecht (bijvoorbeeld, een student beheerst $50 \%$ van alle mogelijke vaardigheden). Betrouwbaarheidscoëfficiënten zijn in het laatste geval altijd lager omdat verschillen in moeilijkheidsgraad tussen stations, in tegenstelling tot het norm-georiënteerde perspectief, als error worden beschouwd. Vergelijking van de twee 
betrouwbaarheidsindices is vooral van belang indien analytische en globale beoordelingen verschillen in het algemene niveau van waardering.

Voor de validiteitsstudies werd gebruik gemaakt van zowel generaliseerbaarheidsanalyses als correlationele analyses. Door analyse van geschatte variantiecomponenten in een design waarin de beoordelingsvorm werd opgenomen (Personen $\mathrm{x}$ Beoordelingsvorm $\mathrm{x}$ Stations) kan een totaalindruk worden verkregen van de mate waarin de globale en analytische methode verschillen in de waardering van de prestaties van studenten. Voor de overige validiteitsvraagstellingen werd gebruik gemaakt van correlationele analyses.

\section{Controle experiment}

In het academisch jaar 1989/1990 werd bij 33 vijfdejaars en bij 25 zesdejaars studenten voor een beperkt aantal stations een additionele globale beoordeling verzameld door inschakeling van een extra observator. Deze observator vulde onafhankelijk van de andere observator alleen het globale oordeel per student in. De 'reguliere' observator vulde zowel een criterialijst in als een globale beoordeling. Daarnaast was voor een aantal studenten en stations een 'reguliere' coobservator voorhanden.

Verschillen in resultaten op globale beoordelingen verkregen tussen de conditie criterialijst ingevuld/niet ingevuld kunnen worden opgevat als de invloed van de criterialijst. Een probleem echter bij deze vergelijking is dat eventuele verschillen gecontamineerd kunnen zijn door het feit dat er sprake is van verschillende beoordelaars: verschillen kunnen worden veroorzaakt doordat er sprake is van een invloed van de criterialijst, dan wel doordat de additionele observator van mening verschilt met de reguliere observator. Daar waar dit mogelijk is (met name in de correlationele verbanden) zou hiervoor statistisch gecorrigeerd moeten worden. Als basis voor de correctie kan de interbeoordelaarsbetrouwbaarheid worden genomen. 


\section{Resultaten}

\section{Controle-experiment}

In tabel 2 zijn de gemiddelde scores weergegeven gebaseerd op de verschillende beoordelingen. De gemiddelde scores van de extra observator zijn vrijwel identiek aan die van de reguliere observatoren. Het invullen van de criterialijst heeft blijkbaar weinig effect op het niveau van de globale waardering. De hoogte van de beoordelingen door middel van de criterialijsten verschilt niet significant ten opzichte van het globale oordeel.

Tabel 2: Gemiddelde scores per beoordelingsinstrument over alle circuits van de vijfde en zesde jaars toetsen.

\begin{tabular}{llccc}
\hline Conditie & Beoordelings- & $\begin{array}{c}\text { Aantal } \\
\text { lijst }\end{array}$ & personen & Gemiddelde Standaarddeviatie \\
Met criterialijst & Criterialijsten & 58 & 71.97 & 7.84 \\
& Algemene indruk & 58 & 69.19 & 7.92 \\
& Specifiek oordeel & 58 & 68.65 & 7.05 \\
Zonder criterialijst & Algemene indruk & 58 & 67.55 & 7.40 \\
met extra observator & Specifiek oordeel & 58 & 68.54 & 7.09 \\
\hline
\end{tabular}

In tabel 3 is de interbeoordelaarsbetrouwbaarheid weergegeven tussen de observator en co-observator en tussen de observator en extra observator.

Tabel 3: Inserbeoordelaarsbetrouwbaarheid tussen de observator, co-observator en extra-observator (aantal paren tussen haakjes).

\begin{tabular}{lcc} 
& $\begin{array}{c}\text { Observator } \\
\text { met } \\
\text { co-observator }\end{array}$ & $\begin{array}{c}\text { Observator } \\
\text { met }\end{array}$ \\
Criterialijst & $.81(76)$ & - \\
Algemene indruk & $.50(31)$ & $.51(182)$ \\
Specifieke oordelen & $.50(31)$ & $.44(182)$ \\
\hline
\end{tabular}

De interbeoordelaarsbetrouwbaarheid voor de criterialijsten is beduidend hoger dan voor de globale beoordelingen. In de resultaten van het hoofdexperiment zal hierop nader worden teruggekomen. Voor het controle-experiment zijn de verschillen in interbeoordelaarsbetrouwbaarheid tussen de criterialijst en het globale oordeel, gegeven het feit of 
eerst een criterialijst wordt ingevuld of niet, van belang. Voor het algemene oordeel is de interbeoordelaarsbetrouwbaarheid tussen beide condities nagenoeg gelijk, terwijl deze voor de specifieke oordelen wat lager uitvalt. Er is blijkbaar sprake van een gering positief effect op de interbeoordelaarsbetrouwbaarheid van het invullen van criterialijsten vór het invullen van globale oordelen.

De interbeoordelaarsbetrouwbaarheden zijn niettemin betrekkelijk laag. Verschillen tussen de observatoren die al of niet een criterialijst invulden kunnen daarmee gecontamineerd zijn.

In tabel 4 zijn de correlaties tussen de verschillende beoordelingsinstrumenten weergegeven. Voor die correlaties waarbij sprake was van een correlatie tussen verschillende observatoren (dus waarbij de beoordeling niet door dezelfde persoon werd gegeven) is een attenuatiecorrectie uitgevoerd door de interbeoordelaarsbetrouwbaarheden te nemen van de observator en extra observator uit tabel 3.

De geobserveerde correlaties laten zien dat het verband tussen criterialijst en globaal oordeel hoger is indien eerst een criterialijst werd ingevuld. $\mathrm{Na}$ een attenuatiecorrectie is dit effect echter verdwenen en eerder omgekeerd.

Tabel 4: Correlaties tussen de diverse beoordelingsschalen uitgesplitst naar conditit (voor attenuatie gecorrigeerde correlaties tussen haakjes).

\begin{tabular}{|c|c|c|c|c|c|}
\hline & \multicolumn{3}{|c|}{$\begin{array}{c}\text { Voorafgaande invulling } \\
\text { criterialijst }\end{array}$} & \multicolumn{2}{|c|}{$\begin{array}{l}\text { Directe invulling } \\
\text { globaal oordeel }\end{array}$} \\
\hline & $\begin{array}{l}\text { Criteria } \\
\text { lijsten }\end{array}$ & $\begin{array}{l}\text { Algemene } \\
\text { indruk }\end{array}$ & $\begin{array}{l}\text { Specifiek } \\
\text { oordeel }\end{array}$ & $\begin{array}{l}\text { Algemene } \\
\text { indruk }\end{array}$ & $\begin{array}{c}\text { Specifiek } \\
\text { oordeel }\end{array}$ \\
\hline Criterialijsten & - & & & & \\
\hline Alg. indruk & .84 & - & & & \\
\hline Spec. oordeel & .79 & .93 & 一 & & \\
\hline $\begin{array}{l}\text { Alg. indruk } \\
\text { (directe invulling) }\end{array}$ & $.65(.91)$ & $.67(.94)$ & $.68(.95)$ & - & \\
\hline $\begin{array}{l}\text { Spec. oordeel } \\
\text { (directe invulling) }\end{array}$ & $.59(.89)$ & $.57(.86)$ & $.59(.89)$ & .90 & - \\
\hline
\end{tabular}

Hoewel wellicht door de betrekkelijk lage interbeoordelaarsbetrouwbaarheden een overcorrectie plaatsvindt, lijkt het niettemin opnieuw gerechtvaardigd om te concluderen dat het invullen van de criterialijst geen drastische effecten heeft op het globale oordeel. 
In het hoofdexperiment vormen betrouwbaarheidsschattingen berekend op variantiecomponenten een belangrijk onderdeel van analyse. Met de gegevens van het controle-experiment kan worden nagegaan of variantiecomponenten van globale oordelen verschillen als gevolg van het invullen van de criterialijst. Tabel 5 bevat deze resultaten, waarbij volgens eenzelfde design (all random $\mathrm{P} \times \mathrm{S}$ ) als hierboven aangegeven voor het hoofdexperiment schattingen zijn uitgevoerd (voor de volledigheid zijn de resultaten van de criterialijsten toegevoegd). Een tendens valt te constateren dat bij het alleen invullen van de globale beoordeling een lagere persoonscomponent wordt bereikt en een hogere error-component, hetgeen in een verlaagde betrouwbaarheid zal resulteren. Niettemin zijn de verschillen niet erg groot in verhouding tot de nauwkeurigheid van de schatting van deze variantiecomponenten zoals blijkt uit de bijbehorende standard errors.

Vatten we de resultaten van het controle-experiment samen, dan kan gesteld worden dat het invullen van een criterialijst enige invloed heeft op de navolgende globale beoordeling, maar dat dit effect geen dramatische vertekening oplevert. Het contaminerende effect van de methodologisch onwenselijke conditie van afname van de globale beoordelingen in het hoofdexperiment lijkt daarmee slechts een beperkte bias op te leveren. 
Tabel 5: Geschatte variantiecomponenten per beoordelingscategorie uitgesplitst naar beoordelaars.

\begin{tabular}{|c|c|c|c|c|c|c|}
\hline & \multicolumn{6}{|c|}{ Voorafgaande invulling criterialijst } \\
\hline & \multicolumn{2}{|c|}{ Criterialijst } & \multicolumn{2}{|c|}{ Algemene indruk } & \multicolumn{2}{|c|}{ Specifiek oordeel } \\
\hline $\begin{array}{l}\mathrm{Va} \\
\mathrm{Con}\end{array}$ & $\begin{array}{l}\text { ariantie } \\
\text { mponent }\end{array}$ & $\begin{array}{l}\text { Standard } \\
\text { Error }\end{array}$ & $\begin{array}{l}\text { Variantie } \\
\text { Component }\end{array}$ & $\begin{array}{l}\text { Standard } \\
\text { Error }\end{array}$ & $\begin{array}{l}\text { Variantie } \\
\text { Component }\end{array}$ & $\begin{array}{c}\text { Standard } \\
\text { Error }\end{array}$ \\
\hline Personen & 39.19 & 11.35 & 47.61 & 11.99 & 34.78 & 9.49 \\
\hline Stations & 95.48 & 61.31 & 22.71 & 15.09 & 16.87 & 11.36 \\
\hline \multirow[t]{4}{*}{ Error } & 84.93 & 9.13 & 67.24 & 7.22 & 63.77 & 6.85 \\
\hline & \multicolumn{6}{|c|}{ Directe invulling globaal oordeel } \\
\hline & \multicolumn{3}{|c|}{ Algemene indruk } & \multicolumn{2}{|c|}{ Specifiek oordeel } & \\
\hline & $\begin{array}{l}\mathrm{Va} \\
\mathrm{Com}\end{array}$ & $\begin{array}{l}\text { ariantie } S \\
\text { mponent }\end{array}$ & $\begin{array}{l}\text { Etandard } \\
\text { Error }\end{array}$ & $\begin{array}{l}\text { Variantie } \\
\text { Component }\end{array}$ & $\begin{array}{l}\text { Standard } \\
\text { Error }\end{array}$ & \\
\hline Personen & & 29.70 & 9.89 & 29.90 & 8.30 & \\
\hline Stations & & 7.30 & 5.59 & 6.59 & 4.79 & \\
\hline Error & & 89.63 & 9.63 & 57.57 & 6.18 & \\
\hline
\end{tabular}

\section{Hoofdexperiment}

Vergelijkbaarheid oorspronkelijke populatie en experimentele groep In eerste instantie is nagegaan in hoeverre de uitval van studenten en stations als gevolg van ontbrekende gegevens van globale oordelen een vertekening heeft geïntroduceerd in de resultaten. In tabel 2 zijn beschrijvende statistieken weergegeven van de vaardigheidstoetsresultaten gebaseerd op de criterialijsten van alle studenten en van de groep studenten die uiteindelijk in de analyse zijn opgenomen. 
Tabel 6: Vergelijking van gemiddelden en standaarddeviaties (Sd) tussen resultaten. behaald op de vaardigheidstoets met betrekking tot de oorspronkelijke groep studenten en de in de steekproef betrokken studenten.

\begin{tabular}{cccccccc}
\hline & \multicolumn{3}{c}{ Oorspronkelijk } & & \multicolumn{3}{c}{ In Steekproef } \\
\cline { 2 - 3 } \cline { 5 - 7 } Jaar & Gemiddelde & Sd & $\mathrm{N}$ & & Gemiddelde & Sd & $\mathrm{N}$ \\
1 & 77.96 & 7.77 & 144 & & 79.34 & 7.12 & 93 \\
2 & 76.69 & 9.43 & 139 & & 78.36 & 9.32 & 76 \\
3 & 73.87 & 9.11 & 115 & & 74.84 & 9.20 & 63 \\
4 & 77.41 & 9.18 & 127 & & 77.52 & 9.89 & 80 \\
$5^{*}$ & 69.27 & 8.45 & 117 & & 73.65 & 9.45 & 88 \\
$6^{* *}$ & 79.07 & 7.73 & 111 & & 81.43 & 8.36 & 90 \\
Totaal & 75.83 & 9.22 & 753 & & 77.68 & 9.23 & 490 \\
\hline
\end{tabular}

* $\mathrm{p} \leq 0.01$

$* * p \leq 0.05$

Uit deze gegevens blijkt dat de onderzochte steekproef met betrekking tot het scoreniveau weinig verschilt ten opzichte van de oorspronkelijke populatie. Wel is scoren de studenten in de steekproef systematisch hoger.

Aangezien in verdere analyses een sterk beroep wordt gedaan op de generaliseerbaarheidstheorie, is tevens nagegaan of de variantieverhoudingen tussen steekproefgegevens en oorspronkelijke gegevens vergelijkbaar zijn. Tabel 7 bevat geschatte variantiecomponenten voor beide groepen. Uit de tabel blijkt dat de variantiecomponenten van beide gegevensbestanden goed vergelijkbaar zijn. De conclusie met betrekking tot de vergelijkbaarheid van de experimentele groep met de oorspronkelijke groep is dan ook dat de uitval van gegevens niet tot een vertekende steekproel heeft geleid ten opzichte van de oorspronkelijke gegevens. 
Tabel 7: Variantiecomponenten yan de scores van de oorspronkelijke groep studenten vergeleken met de in de steekproef betrokken studenten.

\begin{tabular}{|c|c|c|c|c|c|}
\hline \multirow[b]{2}{*}{ Jaar } & \multirow[b]{2}{*}{ Bron } & \multicolumn{2}{|c|}{ Oorspronkelijk } & \multicolumn{2}{|c|}{ In Analyse betrokken } \\
\hline & & $\begin{array}{l}\text { Variantie } \\
\text { Component }\end{array}$ & $\begin{array}{l}\text { Standard } \\
\text { Error }\end{array}$ & $\begin{array}{c}\text { Variantie } \\
\text { Component }\end{array}$ & $\begin{array}{c}\text { Standard } \\
\text { Error }\end{array}$ \\
\hline \multirow[t]{3}{*}{1} & $\mathrm{p}$ & 26.34 & 7.33 & 17.03 & 7.63 \\
\hline & $\mathrm{s}$ & 17.41 & 9.11 & 14.71 & 8.30 \\
\hline & ps & 277.64 & 12.39 & 269.51 & 15.00 \\
\hline \multirow[t]{3}{*}{2} & $\mathrm{p}$ & 37.58 & 19.16 & 36.92 & 25.78 \\
\hline & s & 19.55 & 15.19 & 34.51 & 27.39 \\
\hline & ps & 202.36 & 24.57 & 205.71 & 34.53 \\
\hline \multirow[t]{3}{*}{3} & $p$ & 62.64 & 19.16 & 55.00 & 24.47 \\
\hline & s & 131.14 & 60.99 & 134.42 & 71.72 \\
\hline & $\mathrm{ps}$ & 199.58 & 16.32 & 187.57 & 24.09 \\
\hline \multirow[t]{3}{*}{4} & $\mathrm{p}$ & 58.76 & 17.94 & 58.93 & 23.96 \\
\hline & s & 98.06 & 51.00 & 65.86 & 41.21 \\
\hline & ps & 167.51 & 14.94 & 146.10 & 20.23 \\
\hline \multirow[t]{3}{*}{5} & $\mathrm{p}$ & 49.85 & 18.78 & 54.90 & 23.19 \\
\hline & s & 62.49 & 32.78 & 67.76 & 40.15 \\
\hline & ps & 277.18 & 23.72 & 216.32 & 25.32 \\
\hline \multirow[t]{3}{*}{6} & $\mathrm{p}$ & 31.76 & 13.01 & 31.61 & 17.60 \\
\hline & s & 111.55 & 54.99 & 79.43 & 46.96 \\
\hline & $\mathrm{ps}$ & 147.89 & 14.77 & 165.10 & 21.95 \\
\hline \multirow[t]{3}{*}{ Totaal } & $\mathrm{p}$ & 43.89 & 16.33 & 41.32 & 19.90 \\
\hline & $\mathrm{s}$ & 69.72 & 37.62 & 62.94 & 37.61 \\
\hline & ps & 214.07 & 18.16 & 200.20 & 23.18 \\
\hline
\end{tabular}

\section{Vergelijking van analytische en globale beoordelingen}

\section{Beschrijvende statistieken}

In eerste instantie zijn de gemiddelden en standaarddeviaties per beoordelingslijst per jaargroep berekend (tabel 8). Ervan uitgaande dat de numerieke schalen vergelijkbaar zijn, dan liggen de scores voor de criterialijsten gemiddeld zo'n tien procent hoger dan voor de globale oordelen. Dit is een groot verschil. De spreiding bij het criterialijstoordeel ligt ook systematisch hoger dan voor het globale oordeel. Uitgesplitst per domein over alle jaargroepen heen is het beeld iets 
gevarieerder (tabel 9). Desalniettemin bestaan hier ook aanzienlijke verschillen tussen de beoordelingslijsten.

Met name valt op dat er discrepanties bestaan tussen de gemiddelden en standaarddeviaties van beide beoordelingsvormen op het domein van therapeutische vaardigheden, oogheelkunde, gynaecologie en KNO. Op deze domeinen valt het criterialijstoordeel veel hoger uit, in grootte variërend van $12.18 \%$ tot $27.34 \%$

Tabel 8: Gemiddelden en standaarddeviaties per jaargroep voor de diverse beoordelingsinstrumenten.

\begin{tabular}{|c|c|c|c|c|c|c|c|}
\hline \multirow[b]{2}{*}{ Jaar } & \multirow[b]{2}{*}{$\mathrm{N}$} & \multicolumn{2}{|l|}{$\begin{array}{c}\text { Criterialijst } \\
\text { oordeel }\end{array}$} & \multicolumn{2}{|c|}{$\begin{array}{l}\text { Algemene } \\
\text { indruk }\end{array}$} & \multicolumn{2}{|c|}{$\begin{array}{c}\text { Specifiek } \\
\text { globaal oordeel }\end{array}$} \\
\hline & & Gemiddelde & SD & Gemiddelde & SD & Gemiddelde & $\mathrm{SD}$ \\
\hline 1 & 93 & 79.34 & 7.12 & 68.45 & 5.46 & 67.44 & 5.18 \\
\hline 2 & 76 & 78.36 & 9.32 & 69.83 & 8.42 & 69.86 & 7.78 \\
\hline 3 & 63 & 74.84 & 9.20 & 68.45 & 6.90 & 67.19 & 6.36 \\
\hline 4 & 80 & 77.52 & 9.89 & 68.52 & 7.31 & 68.20 & 6.28 \\
\hline 5 & 88 & 73.65 & 9.45 & 67.80 & 6.32 & 68.34 & 5.48 \\
\hline 6 & 90 & 81.43 & 8.36 & 69.91 & 6.30 & 69.76 & 5.82 \\
\hline Tot. & 490 & 77.68 & 9.23 & 68.83 & 6.79 & 68.49 & 6.19 \\
\hline
\end{tabular}

Kindergeneeskunde is het enige domein waarbij het criterialijstoordeel lager lag dan het globale oordeel. De oorzaak hiervan is niet duidelijk. De algemene indruk volgt qua scores ook hier de meer specifieke globale oordelen.

Het veronderstellen van een gelijke numerieke schaal bij beide (analytisch versus globaal) beoordelingsvormen is een niet erg aannemelijke assumptie. Aangezien het globale oordeel tot stand komt op basis van een cijfer dat loopt van één tot en met tien, kan men globale oordelen van een zes of meer als voldoende beschouwen. Bij analytische oordelen is de voldoende/onvoldoende grens gelegd op zeventig procent of meer, hetgeen de norm is die nu gehanteerd wordt bij examenbeslissingen met betrekking tot de herkansingstoetsen. Uitgaande van die grenzen wijken beide beoordelingsvormen ongeveer even ver af van de cesuur en is er dus minder sprake van algemene niveauverschillen. 
Tabel 9: Gemiddelde scores en standaarddeviaties per vaardigheidsonderdeel (domein) per beoordelingslijst over het hele jaar.

\begin{tabular}{|c|c|c|c|c|c|c|c|}
\hline \multirow[b]{2}{*}{ Domein } & \multicolumn{3}{|c|}{$\begin{array}{c}\text { Criterialijst } \\
\text { oordeel }\end{array}$} & \multicolumn{2}{|c|}{$\begin{array}{l}\text { Algemene } \\
\text { indruk }\end{array}$} & \multicolumn{2}{|c|}{$\begin{array}{c}\text { Specifiek } \\
\text { oordeel }\end{array}$} \\
\hline & $\mathrm{N}$ & Gemiddelde & SD & Gemiddelde & SD & Gemiddelde & SD \\
\hline & & 1 & & 2 & & 3 & \\
\hline Neurologie & 170 & $73.13^{* *}$ & 19.10 & 68.52 & 13.52 & $69.00 * *$ & 10.79 \\
\hline Therap. vh. & 246 & $87.50 * *$ & 13.52 & $60.16^{* *}$ & 12.22 & $69.63^{* * *}$ & 11.15 \\
\hline Abdomen & 337 & $77.89 * *$ & 14.94 & 70.59 & 11.55 & $71.12 * *$ & 9.51 \\
\hline Thorax & 244 & $73.89 * *$ & 17.55 & 67.82 & 11.07 & $68.61^{* *}$ & 9.29 \\
\hline Oogheelk. & 117 & $83.17^{* *}$ & 17.75 & 68.03 & 13.66 & $68.61^{* *}$ & 12.41 \\
\hline Gyn./Obstr. & 229 & $82.42 * *$ & 13.18 & 70.74 & 12.97 & $69.94 * *$ & 12.36 \\
\hline Bew.app. & 319 & $75.29 * *$ & 17.42 & 68.80 & 12.30 & $67.97 * *$ & 11.46 \\
\hline $\mathrm{KNO}$ & 197 & $79.48 * *$ & 16.12 & 67.30 & 14.11 & $67.19 * *$ & 11.01 \\
\hline Kindergen. & 29 & 65.20 & 12.67 & 66.55 & 10.44 & 67.01 & 9.48 \\
\hline Sociale vh. & 400 & $77.49 * *$ & 15.55 & 68.69 & 10.89 & $69.09 * *$ & 9.37 \\
\hline Lab. vh. & 232 & $74.79 * *$ & 15.97 & $66.37 * *$ & 9.78 & $63.96^{* *}$ & 10.33 \\
\hline
\end{tabular}

1 criterialijst met algemene indruk

$$
{ }^{* *} \mathbf{p} \leq 0.01
$$

2 algemene indruk met specifiek oordeel

3 specifiek oordeel met criterialijst

\section{Betrouwbaarheid}

Voor de schatting van de interbeoordelaarsbetrouwbaarheid worden de gegevens van alle paren observatoren/co-observatoren gebruikt die aanwezig zijn binnen de steekproef van 490 studenten. Variantiecomponenten werden berekend volgens een design waarin beoordelaars genest zijn binnen personen (B:P).

Vervolgens werden generaliseerbaarheidcoëfficiënten berekend per beoordelingslijst. Deze generaliseerbaarheidscoefficiënt geeft de mate van interbeoordelaarsbetrouwbaarheid aan waarbij eveneens algemene verschillen tussen observatoren als error worden beschouwd.

Deze interbeoordelaarsbetrouwbaarheden voor criterialijsten, voor de algemene indruk en voor de specifieke indruk zijn respectievelijk .81, .59 en .58 (tabel 10). Hieruit blijkt dus, behalve in het vijfde studiejaar, een aanzienlijk lagere interbeoordelaarsbetrouwbaarheid voor de globale 
oordelen. Voor de lage interbeoordelaarsbetrouwbaarheid in het vijfde studiejaar is geen verklaring.

Tabel 10: Interbeoordelaarsbetrouwbaarheid voor de diverse criterialijsten per jaargroep.

$\begin{array}{crccc}\text { Jaar } & \begin{array}{c}\text { Aantal } \\ \text { paren }\end{array} & \begin{array}{c}\text { Criterialijst } \\ \text { oordeel }\end{array} & \begin{array}{c}\text { Algemene } \\ \text { indruk }\end{array} & \begin{array}{c}\text { Specifiek } \\ \text { oordeel }\end{array} \\ 1 & 203 & .83 & .49 & .49 \\ 2 & 106 & .84 & .73 & .71 \\ 3 & 94 & .82 & .60 & .55 \\ 4 & 140 & .82 & .51 & .52 \\ 5 & 100 & .65 & .68 & .63 \\ 6 & 169 & .82 & .61 & .64 \\ \text { Total } & 812 & .81 & .59 & .58\end{array}$

Tabel 11: Variantiecomponenten uitgesplitst naar de beoordelingscategorieën algemene indruk en specifiek oordeel.

\begin{tabular}{lccccc}
\hline & \multicolumn{2}{c}{ Algemene indruk } & & \multicolumn{2}{c}{ Specifiek oordeel } \\
\cline { 2 - 3 } \cline { 5 - 6 } Bron & $\begin{array}{c}\text { Variantie } \\
\text { Component }\end{array}$ & $\begin{array}{c}\text { Standard } \\
\text { Error }\end{array}$ & & $\begin{array}{c}\text { Variantie } \\
\text { Component }\end{array}$ & $\begin{array}{c}\text { Standard } \\
\text { Error }\end{array}$ \\
Personen (P) & 32.49 & 3.42 & & 30.14 & 3.27 \\
Formaat (F) & 43.26 & 38.68 & & 46.19 & 41.11 \\
Stations (S) & 18.61 & 17.62 & & 16.98 & 16.82 \\
P x F & 2.10 & 0.95 & & 3.68 & 1.00 \\
P x S & 94.62 & 3.71 & & 90.13 & 3.55 \\
F x S & 20.00 & 11.61 & & 20.24 & 11.74 \\
PFS, error & 67.06 & 1.87 & & 65.05 & 1.82 \\
\hline
\end{tabular}

Voor elke student is een dubbele beoordeling beschikbaar: enerzijds een beoordeling met de criterialijst, anderzijds met het globale oordeel. Om het effect van de beoordelingswijze gegeven een bepaalde beoordelingslijst in te schatten werden per circuit variantiecomponenten geschat volgens een design personen $\mathrm{x}$ stations $\mathrm{x}$ formaat. Dit werd dubbel verricht, enerzijds voor een beoordelingscategorie waarin het algemene oordeel betrokken was en anderzijds voor een beoordelingscategorie met specifieke oordelen. Vervolgens werden de variantiecomponenten over circuits en jaargroepen gemiddeld (gewogen naar steekproefgrootte) ter 
vergelijking van én schatting. Hierbij is volstaan met een weergave op totaalniveau, tabel 11 bevat de resultaten.De persoonscomponent (P) geeft de ware verschillen tussen de verschillende kandidaten aan. Het formaat $(F)$ geeft de algemene invloed of de systematische niveauverschillen aan van de vorm (algemene indruk versus specifieke globale oordelen) van de beoordelingslijst op de beoordeling. Deze component is ten opzichte van de andere variantiecomponenten personen en stations relatief groot. De stationscomponent (S) geeft aan in hoeverre stations verschillen in moeilijkheidsgraad. De interactie tussen personen en formaat $(\mathrm{PxF})$ geeft aan de mate waarin studenten door beide beoordelingsvormen anders worden gerangordend. Deze factor is ten opzichte van de andere variantiecomponenten bijzonder klein. Dit betekent dat er een hoge correlatie is tussen beide vormen van beoordeling.

De interactie tussen personen en stations geeft de mate aan waarin personen over stations heen anders worden gerangordend. Dit wordt verklaard uit de specifieke kennis die vereist is bij het goed uitvoeren van bepaalde handelingen. Dit noemt men ook wel "casusspecificiteit". Deze component is zeer groot, conform eerdere bevindingen met diverse meetinstrumenten (Van der Vleuten, 1989-C). De interactiecomponent tussen formaat en stations (FxS) geeft aan in hoeverre verschillen in moeilijkheidsgraad tussen stations anders zijn voor beide beoordelingsvormen. Er is hier blijkbaar sprake van enige verschillen.

De laatste term is de error term en geeft de interactie aan tussen personen, formaat en stations. Ook deze term is relatief groot, hetgeen bij elke meting het geval is, maar kleiner dan de casusspecificiteitscomponent $(\mathrm{PxS})$.

Samenvattend komt het erop neer dat, hoewel niveauverschillen aanwezig zijn (F), de rangordening van personen (PxF) nagenoeg onveranderd blijft. Er zijn geen verschillen in dit opzicht tussen een algemeen globaal oordeel en specifieke globale oordelen. Klaarblijkelijk is de meetinformatie van de specifieke globale oordelen nagenoeg dezelfde als van de algemene indruk (de intercorrelatie tussen deze twee beoordelingscriteria bedraagt .92 )

Voor de schatting van variantiecomponenten gegeven een bepaalde beoordelingsvorm is per circuit een personen (P) maal stations (S) analyse verricht en over circuits heen gemiddeld. Tabel 12 bevat deze gegevens. 
Aangezien criterialijsten voornamelijk items met betrekking tot technisch handelen bevatten ligt het voor de hand dat met dat aspect van het globale oordeel de hoogste correlatie gevonden wordt. Het gevonden verband is hoog (.78), maar dat is het ook tussen criterialijst en bedrevenheid. De houding ten opzichte van de patiënt vertoont de laagste correlaties met de andere beoordelingscategorieën. Dit is niet zo verwonderlijk aangezien hiervoor geen specifieke items in de criterialijsten zijn opgenomen.

Tabel 14: Correlationele verbanden tussen criterialijsten met de algemene indruk en met de combinatie en de afzonderlijke items van de volgende globale oordelen: de techniek van het onderzoek, de bedrevenheid tijdens het onderzoek en de houding ten opzichte van de patiënt over alle jaargroepen.

Beoordelingscategorieën

Criterialijst Algemene indruk Globaal oordeel Techniek Bedrevenheid Houding
Criterialijst indruk
Specifiek Techniek oordeel
Bedreven- Houding heid

Tabel 15: Correlationele verbanden tussen de criterialijsten, de algemene indruk en het specifieke globale oordeel.

\begin{tabular}{cccc}
\hline Jaar & $\begin{array}{c}\text { Criterialijsten met } \\
\text { algemene indruk }\end{array}$ & $\begin{array}{c}\text { Criterialijsten met } \\
\text { specifieke oordelen }\end{array}$ & $\begin{array}{c}\text { Algemene indruk met } \\
\text { specifieke oordelen }\end{array}$ \\
1 & .76 & .71 & .93 \\
2 & .85 & .85 & .92 \\
3 & .84 & .86 & .94 \\
4 & .86 & .80 & .93 \\
5 & .83 & .82 & .91 \\
6 & .82 & .80 & .92 \\
Totaal & .81 & .78 & .92 \\
\hline
\end{tabular}

De correlationele verbanden tussen de criterialijsten, de algemene indruk en het specifieke globale oordeel zijn in tabel 15 ook nog eens uitgesplitst per jaargroep. Hierbij worden zeer hoge correlaties gevonden. Met name correleert de algemene indruk hoog met het 
specifieke globale oordeel. Correlaties tussen criterialijsten en globale oordelen zijn in het eerste studiejaar relatief iets lager dan in de overige studiejaren. Dit is mogelijk te verklaren doordat in het eerste studiejaar analytische criterialijsten het meest frequent gebruikt worden, zodat eventuele verschillen tussen criterialijsten en globale oordelen daar het meest naar voren zullen komen.

Om eventuele inhoudelijke verschillen tussen criterialijsten en algemene indruk nader te onderzoeken is de relatieve bijdrage nagegaan van de specifieke globale oordelen ten opzichte van de criterialijsten en de algemene indruk. Met andere woorden: welke elementen wegen het zwaarste in het tot stand komen van het algemeen oordeel en welke in de criterialijst?

Daartoe zijn de boven omschreven correlaties onderworpen aan een multiple regressie analyse (stepwise), waarbij eerst de criterialijsten (tabel 16) en vervolgens de algemene indruk (tabel 17) als criterium variabelen worden beschouwd en de specifieke oordelen als predictoren. Uit tabel 16 kan men aflezen dat het item "techniek" van de specifieke globale oordelen, het zwaarste gewicht heeft in het criterialijstoordeel ( $\beta$ $=.71$ ). Ook de houding van de student speelt hierbij een rol, hoewel slechts in geringe mate. Het item "bedrevenheid" draagt niet significant bij in het criterialijstoordeel. De multiple R bedraagt hier .78. Dit betekent dat het kwadraat hiervan het percentage van de verklaarde variantie oplevert $(61 \%)$.

Tabel 16: Multiple regressie van de drie items uit de specifieke beoordeling(predictoren) met de scores van de criterialijsten als afhankelijke variabele.

\begin{tabular}{lcccc}
\hline & $\begin{array}{c}\text { Gewicht } \\
(\mathrm{B})\end{array}$ & $\begin{array}{c}\text { Standard } \\
\text { Error }(\mathrm{B})\end{array}$ & $\beta$ & \\
Beoordelingscategorie & .89 & .04 & .71 & $\mathrm{p}<.0001$ \\
Techniek & .16 & .05 & .10 & $\mathrm{p}<.005$ \\
Houding & & & & \\
Multiple $\mathrm{R}=.78$ & & & \\
\hline
\end{tabular}

Uit tabel 17 is af te lezen welke aspecten van de specifieke oordelen het meest bijdragen tot de algemene indruk. Hieruit blijkt dat de score voor de algemene indruk eveneens het beste wordt voorspeld vanuit het technisch handelen van de student $(\beta=.46)$. De andere factoren, 
bedrevenheid en houding ten opzichte van de patiënt wegen echter ook mee ( $\beta$ respectievelijk .35 en .17). Deze laatste twee factoren zorgen echter voor een geringe stijging van het percentage verklaarde variantie van $81 \%$ (voor alleen het item techniek) tot $85 \%$ (voor de items techniek, bedrevenheid en systematiek).

Tabel 17: Multiple regressie van specifieke globale oordelen met de scores van de totaal-indruk als afhankelijke variabele.

\begin{tabular}{lcccc}
\hline & $\begin{array}{c}\text { Gewicht } \\
\text { (B) }\end{array}$ & $\begin{array}{c}\text { Standard } \\
\text { Error (B) }\end{array}$ & $\beta$ & \\
Beoordelingscategorie & & & & \\
Techniek & .42 & .04 & .46 & $\mathrm{p} \leq .0001$ \\
Bedrevenheid & .32 & .04 & .35 & $\mathrm{p} \leq .0001$ \\
Houding & .20 & .02 & .17 & $\mathrm{p} \leq .0001$ \\
Multiple R $=.92$ & & & & \\
\hline
\end{tabular}

Samenvattend komt het erop neer dat zowel het criterialijstoordeel als ook de algemene indruk in overheersende mate bepaald wordt door het niveau van het technisch handelen van de student. De houding en de bedrevenheid voegen hier weinig substantieels aan toe.

Een andere manier om zicht te krijgen op mogelijke verschillen tussen globale en gedetailleerde beoordelingen is de relatie tussen deze beoordelingen en de algemene medische kennistoets, de zogenaamde voortgangstoets als extern criterium. In tabel 18 zijn de correlationele verbanden aangegeven tussen de diverse beoordelingsvormen en de voortgangstoets gesplitst in geobserveerde correlaties en ware correlaties. De ware correlaties zijn correlaties gecorrigeerd voor onbetrouwbaarheid. Uit tabel 18 blijkt dat de gevonden correlationele verbanden laag zijn en sterker worden voor alle criterialijsten bij het vorderen van de studie. Tussen de criterialijsten onderling bestaan geen verschillen ten aanzien van de gevonden correlaties met de voortgangstoets. Globale oordelen verschillen in dit opzicht dus niet van de criterialijsten. Het lijkt erop dat ze soortgelijke zaken meten. 
Tabel 18: Correlationele verbanden tussen de uitkomsten van de criterialijst, algemene indruk en specifieke globale oordelen met de voortgangstoets (geobserveerde en ware correlaties).

\begin{tabular}{|c|c|c|c|c|c|c|}
\hline \multirow[t]{2}{*}{ Jaar } & \multicolumn{2}{|c|}{ Criterialijsten } & \multicolumn{2}{|c|}{ Algemene indruk } & \multicolumn{2}{|c|}{$\begin{array}{c}\text { Specifieke globale } \\
\text { oordelen }\end{array}$} \\
\hline & $\begin{array}{l}\text { Geobs. } \\
\text { corr. }\end{array}$ & $\begin{array}{l}\text { Ware } \\
\text { corr. }\end{array}$ & $\begin{array}{c}\text { Geobs. } \\
\text { corr. }\end{array}$ & $\begin{array}{l}\text { Ware } \\
\text { corr. }\end{array}$ & $\begin{array}{l}\text { Geobs } \\
\text { corr. }\end{array}$ & $\begin{array}{l}\text { Ware } \\
\text { corr. }\end{array}$ \\
\hline 1 & .06 & .10 & .04 & .05 & -.08 & -.01 \\
\hline 2 & .20 & .32 & .18 & .26 & .13 & .18 \\
\hline 3 & .19 & .24 & .20 & .27 & .19 & .25 \\
\hline 4 & .24 & .31 & .24 & .35 & .25 & .35 \\
\hline 5 & .29 & .40 & .29 & .39 & .33 & .44 \\
\hline 6 & .38 & .56 & .34 & .53 & .32 & .51 \\
\hline
\end{tabular}

Op voorhand werden er geen verschillen verwacht tussen beide soorten beoordelingsvormen. Gezien het feit dat vaardigheidstoetsen voor een groot deel uit "aan kennis gerelateerde items" bestaan (zie hoofdstuk 6), werden wel iets hogere correlaties verwacht, met name in de hogere studiejaren.

\section{Beslissingen ten aanzien van de studievoortgang}

Is in het voorafgaande aandacht besteed aan de verschillen die optreden bij het gebruik van diverse beoordelingsschalen voor het bepalen van het vaardigheidsniveau, in deze paragraaf wordt bekeken in hoeverre uitkomsten van de verschillende beoordelingsschalen in termen van de kwalificaties voldoende en onvoldoende met elkaar verschillen (de kwalificatie twijfelachtig wordt bij de onvoldoendes gerekend). Voldoende en onvoldoende resultaten berekend voor de criterialijsten zijn in tabel 19 in een kruistabel afgezet tegen voldoende en onvoldoende resultaten op grond van de algemene indruk en de specifieke oordelen. Voor de criterialijsten is als zak/slaag grens genomen een score van $70 \%$ gewogen goed. Deze norm wordt ook gehanteerd binnen het Examenreglement als de score waarboven de student in ieder geval een voldoende vaardigheidsniveau heeft behaald. Voor het globale oordeel is een 10-puntsschaal ("cijferlijst") gebruikt. Hierbij wordt de "zes" als regel als voldoende resultaat beschouwd. Vandaar dat hier ook 
gekozen is voor de "zes" als grenswaarde tussen voldoende en onvoldoende resultaat.

Tabel 19: Kruistabellen van kwalificaties van alle studenten (voldoende; onvoldoende) tussen criterialijsten enerzijds met algemene indruk en specifiek oordeel anderzijds (absolute aantallen).

\begin{tabular}{|c|c|c|c|c|c|c|c|}
\hline \multirow[b]{2}{*}{ Criterialijst } & \multicolumn{3}{|c|}{ Algemene indruk } & \multirow[b]{2}{*}{ Criterialijst } & \multicolumn{3}{|c|}{ Specifiek oordeel } \\
\hline & Vold. & Onvold. & Totaal & & Vold. & Onvold. & Totaal \\
\hline Voldoende & 390 & 1 & 391 & Voldoende & 389 & 2 & 391 \\
\hline Onvoldoende & 60 & 39 & 99 & Onvoldoende & 63 & 36 & 99 \\
\hline Totaal & 450 & 40 & 490 & Totaal & 452 & 38 & 490 \\
\hline & \multicolumn{3}{|c|}{$\begin{array}{r}X^{2}=35.35 \\
d f=1 \\
p \leq .0001\end{array}$} & & & \multicolumn{2}{|c|}{$\begin{array}{r}\mathrm{X}^{2}=136.97 \\
\mathrm{df}=1 \\
\mathrm{p} \leq .0001\end{array}$} \\
\hline
\end{tabular}

Tussen de kwalificaties van het globale oordeel (zowel algemeen als specifiek) en de criterialijst bestaat een duidelijk verband. Niettemin zijn er ook duidelijke verschillen. De globale beoordeling leidt tot een groter aantal voldoenden dan de analytische beoordeling. Ruim $13 \%$ van alle studenten zou een voldoende krijgen bij een globale beoordeling en een onvoldoende volgens de criterialijst. Het omgekeerde, een voldoende criterialijstoordeel met een onvoldoende algemene indruk, komt nauwelijks voor. Tussen de algemene indruk en de specifieke beoordelingen bestaan ook hier nauwelijks verschillen.

In tabel 20 wordt de verdeling over de cellen weergegeven (voldoendeniet voldoende; globaal- analytisch) onder de aanname dat de score van het globale oordeel het "ware" oordeel is. De zak/slaaggrens voor de criterialijst werd zodanig verlaagd dat een gelijk aantal onvoldoendes verkregen werd. In dit geval betreft het een verlaging van de norm van $70 \%$ naar $64.20 \%$ Het blijkt dan dat de cellen algemene indruk respectievelijk globaal oordeel onvoldoende en criterialijst oordeel voldoende (hierop spitst zich de kritiek van de observatoren toe) in dat geval ongeveer even sterk gerepresenteerd wordt als de "tegenovergestelde" cel (globaal oordeel voldoende en criterialijstoordeel onvoldoende). Dat is opvallend aangezien observatoren tot op heden in veel mindere mate aangeven dat criterialijsten studenten ook wel eens zouden kunnen bevoordelen ten opzichte van hun eigen oordeel. 
Het absolute aantal discrepanties tussen een voldoende beoordeling op de criterialijst en een onvoldoende algemene indruk respectievelijk globaal oordeel neemt echter wel toe in tabel 20 ten opzichte van tabel 19. Hoewel niet zo extreem, liggen deze verschuivingen meer in de richting van de verwachtingen zoals die door observatoren geuit worden.

Tabel 20: Kruistabellen van kwalificaties van alle studenten (voldoende; onvoldoende) tussen criterialijsten enerzijds met algemene indruk en specifiek oordeel anderzijds (absolute aantallen) waarbij het aantal onvoldoendes bij criterialijsten identiek is gemaakt aan dat van het globale oordeel (algemene indruk) door aanpassing van de zak/slaaggrens bij het gebruik van criterialijsten.

\begin{tabular}{|c|c|c|c|c|c|c|c|}
\hline \multirow[b]{2}{*}{ Criterialijst } & \multicolumn{3}{|c|}{ Algemene indruk } & & \multicolumn{3}{|c|}{ Specifiek oordeel } \\
\hline & Vold. & Onvold. & Totaal & Criterialijst & Vold. & Onvold. & Totaal \\
\hline Voldoende & 438 & 12 & 450 & Voldoende & 436 & 14 & 450 \\
\hline Onvoldoende & 12 & 28 & 40 & Onvoldoende & 16 & 24 & 40 \\
\hline Totaal & 450 & 40 & 490 & Totaal & 452 & 38 & 490 \\
\hline & \multicolumn{3}{|c|}{$\begin{array}{r}\mathrm{X}^{2}=158.33 \\
\mathrm{df}=1 \\
\mathrm{p} \leq .0001\end{array}$} & & & \multicolumn{2}{|c|}{$\begin{array}{r}\mathrm{X}^{2}=213.26 \\
\mathrm{df}=1 \\
\mathrm{P} \leq .0001\end{array}$} \\
\hline
\end{tabular}

In tabel 21 is nagegaan of de verschillen tussen criterialijstoordeel en globaal oordeel uit tabel 19 een gevolg zijn van specifieke onderdelen van de globale beoordeling. Daartoe is de verschilscore berekend tussen de criterialijstscore en de algemene indrukscore. Hierbij is uitgegaan van twee groepen "extremen", dat wil zeggen dat voor de berekening is uitgegaan van $10 \%$ van de meest extreme waarden, zowel voor wat betreft personen die op de algemene indruk een veel lagere score behalen dan de score behaald op de criterialijst alsook het omgekeerde. Van deze beide groepen zijn de scores op de specifieke globale oordelen bekeken. Uit tabel 21 blijkt dat bij deze populatie de gemiddelde scores van de specifieke oordelen techniek en bedrevenheid vrijwel gelijk zijn. Het aspect houding lijkt de scores in beide gevallen in positieve zin te beïnvloeden. Dit lijkt met name het geval bij een algemene indruk die in positicve zin verschilt van de criterialijstscore. 
Tabel 21: Scores van de globale oordelen voor studenten met de grootste positieve en negatieve verschillen in scores tussen de algemene indruk en criterialijstoordelen.

\begin{tabular}{lccccc}
\hline & \multicolumn{2}{c}{ Alg. indruk $<$ Criterialijst } & & \multicolumn{2}{c}{ Alg. indruk $>$ Criterialijst } \\
\cline { 2 - 3 } \cline { 5 - 6 } & Gem & SD & & Gem & SD \\
Criterialijst & 84.88 & 6.12 & & 67.95 & 9.32 \\
Algemene indruk & 67.29 & 5.22 & & 68.87 & 7.77 \\
Specifieke globale oordelen & & & & \\
Techniek & 67.51 & 6.68 & & 67.28 & 7.93 \\
Bedrevenheid & 66.79 & 6.50 & & 67.60 & 7.87 \\
Houding & 69.89 & 5.88 & & 71.67 & 5.76 \\
Totaal & 67.70 & 5.30 & 68.13 & 6.77 \\
\hline
\end{tabular}

Het lijkt erop dat verschillen tussen criterialijstoordelen en globale oordelen soms worden gemaskeerd (bij lage scores van de algemene indruk), soms worden versterkt (bij hoge scores van de algemene indruk) door het houdingsaspect. Gezien echter de geringe verschillen tussen de specifieke oordelen onderling levert dit geen duidelijke aanwijzingen op welke van de drie specifieke oordelen het criterialijstoordeel het meest beïnvloedt.

\section{Discussie}

Vooraf dient gesteld te worden dat de methode welke gekozen is voor de dataverzameling niet optimaal is. De gegevens zijn verzameld tijdens reguliere toetsafnames. Dientengevolge moesten globale oordelen ingevuld worden nadat de observator zijn analytische oordeel al had gegeven. In een controle-experiment bleek overigens dat er weliswaar sprake is van enige beïnloeding, maar dat deze relatief beperkt is van omvang. In een vergelijkbare studie werd dit eveneens gevonden (Van der Vleuten \& Van Luijk. 1987).

Ook de uitval veroorzaakt door ontbrekende globale beoordelingen in cen aantal stations waardoor met een gedeeltelijke data-set diende te worden gewerkt, lijkt geen substantiële vertekening van de resultaten opgeleverd. 
Uit de resultaten bleek dat de waardering van de prestaties van de studenten, conform de verwachting, in absolute zin lager uitviel bij de globale beoordelingswijze dan bij de analytische methode. De criterialijsten leverden een hogere spreiding op. Blijkbaar differentieert een analytische methode meer dan een globale methode. Wanneer echter de verschillen tussen beide methoden uitgedrukt worden in relatie tot de zak/slaagbeslissingen (uitgaande van de bestaande regeling van de vaardigheidstoets), ontstaat er een tegenovergesteld effect: de analytische beoordelingsmethode is strenger dan de globale methode. In dat geval worden met name studenten door de globale methode als voldoende beschouwd en door de analytische methode als onvoldoende. Deze bevinding is geheel tegengesteld aan wat door observatoren wordt gerapporteerd. Een en ander zou, als alternatieve verklaring, erop kunnen duiden dat de gehanteerde norm voor de huidige vaardigheidstoets te hoog is. $\mathrm{Bij}$ het equivaleren van het aantal voldoende en onvoldoende resultaten op beide beoordelingsmethoden is de verdeling van de verschillen ongeveer gelijk. Er zijn echter in dat geval geen typerende afwijkingen te constateren op bepaalde aspecten van het globale oordeel zoals op voorhand zou kunnen worden aangenomen uit de commentaren van observatoren (bijvoorbeeld een goede techniek, maar in combinatie met een ondeugdelijke bedrevenheid of houding ten opzichte van de patiënt).

Uit de betrouwbaarheidsstudies blijkt dat de interbeoordelaarsbetrouwbaarheid conform de bevindingen uit de literatuur aanmerkelijk lager ligt voor de globale beoordelingsmethode dan voor de analytische methode. Zoals aangegeven vormt een vergelijking van de totale betrouwbaarheid een betere indicatie en hieruit blijkt dat beide methoden eigenlijk gelijkwaardig zijn. Dit impliceert dat fouten ontstaan door beoordelaarsvariatie op een individueel station uitmiddelen over stations heen. Deze gelijkwaardigheid kan echter alleen verkregen worden als over meerdere stations beoordeeld wordt en wanneer sprake is van een verschillende beoordelaar voor elk station. Gegeven de lagere interbeoordelaarsbetrouwbaarheid van globale oordelen zou een vergelijking op het totale toetsniveau tussen beide vormen gunstiger kunnen uitvallen voor de globale oordelen indien met dubbele beoordelingen per station zou worden gewerkt. De grootte van dit verschil is met behulp van de bestaande gegevens niet na te gaan, omdat deze data niet beschikbaar zijn (er bestaat geen verzameling studenten met dubbele scores voor alle 
stations). In een vervolgonderzoek zou dit een interessante vraagstelling kunnen zijn.

Uit de inspectie van de variantiecomponenten die ten grondslag lagen aan de betrouwbaarheidsschattingen valt een nadere nuancering aan te geven. Voor globale oordelen wordt een lagere (ware) persoonsvariantie gevonden, maar daar staat een naar verhouding lagere error-term tegenover (waardoor de betrouwbaarheidsschatting voor een normgeoriënteerde interpretatie indifferent blijft). De stations-variantie (moeilijkheidsgraad tussen stations) blijkt bij de analytische beoordeling veel groter. In combinatie met de gegevens uit de beschrijvende statistieken (met name de grotere standaarddeviaties voor de analytische methode) lijkt dit erop te duiden dat het gebruik van criterialijsten een betere "verankering" van de prestaties van de student aan de inhoud van de criterialijst oplevert, leidend tot grotere spreidingen in de waardering. Een globale beoordeling lijkt meer te "dempen" en minder verankerd te zijn. Wellicht dat de oordeelsvorming meer relatief (relatief ten opzichte van andere personen) plaatsvindt, leidend tot meer gelijkvormige gemiddelden van groepen personen onafhankelijk van de specifieke inhoud. Zo bezien zouden globale oordelen beter passen in een normgeoriënteerde toetsbenadering en een analytische beoordeling beter in een domein-georiënteerde benadering. Overigens valt de betrouwbaarheid in dat geval weer ten nadele uit van de analytische methode, omdat de variatie tussen stations (en de moeilijkheidsgraadverschillen van de toets als geheel) in een domein-benadering als error wordt beschouwd, leidend tot relatief ongunstige betrouwbaarheden zoals ook reeds bleek uit tabel 13.

Ten aanzien van de correlationele relatie tussen de analytische en globale beoordelingen bleek dat beide beoordelingsvormen sterk samenhangen. De variantiecomponent Beoordelingsvorm x Personen bleek zeer klein, inhoudende dat beide vormen studenten gelijkvormig rangordenen. Dit bleek tevens uit de Pearson-correlaties tussen globale oordelen. Het verband tussen criterialijst en globaal oordeel bleek het sterkste voor techniek en systematiek en wat minder voor houding ten opzichte van de patiënt. Ook uit de regressieanalyse bleek de techniek van de vaardigheid het zwaarste gewicht in de schaal te leggen. Dit is op zich een logische relatie en zou kunnen inhouden dat daar waar discrepanties optreden tussen analytische en globale methode vooral de houdingsaspecten bepalend zijn. Zoals hierboven reeds was aangegeven was dat echter niet het geval. 
Wat betreft de relatie tussen beide beoordelingsvormen en een criterium, de voortgangstoets, bleken evenmin verschillen te bestaan. Beide beoordelingsvormen lieten betrekkelijk lage maar vooral gelijkvormige correlatiepatronen zien.

Samenvattend kan worden gesteld dat de overeenkomsten tussen globale en analytische oordelen meer in het oog springen, dan de verschillen tussen beide methoden. Zowel wat betreft de betrouwbaarheid als wat betreft de inhoud van de verzamelde informatie komen beide beoordelingsvormen sterk met elkaar overeen.

Voor de praktijk van de vaardigheidstoets zou dit kunnen betekenen dat het oorspronkelijke objectiviteitsargument geen rol van betekenis hoeft te spelen in de keuze van de beoordelingsvorm. Objectiviteit en betrouwbaarheid zijn geen aan elkaar gelijkgeschakelde begrippen. De meetinformatie verzameld met een globale beoordelingsmethode kan een vergelijkbare betrouwbaarheid opleveren als analytisch verzamelde informatie en bovendien blijkt ook de verzamelde informatie inhoudelijk niet veel af te wijken van analytisch verzamelde informatie. Wanneer een globale beoordelingsvorm andere voordelen oplevert, zoals een geringere uitnodiging tot memoriseren van de kant van studenten en een grotere waardering (satisfactie) van de kant van observatoren (het keurslijfprobleem), dan laten de gegevens uit deze studie zien dat hieraan, vanuit een psychometrisch standpunt, weinig nadelen verbonden zijn ten opzichte van criterialijsten. Een voorwaarde is wel dat de toets een voldoende lengte heeft en verschillende beoordelaars per station aanwezig zijn, zodat de grotere verschillen tussen beoordelaars per station kunnen uitmiddelen over de totale toets.

Opgemerkt moet daarbij worden dat in deze studie gekozen werd voor een tamelijk extreme globalisering voor het maximaal differentiëren van eventuele effecten. Er zijn natuurlijk allerlei tussenvormen van globalisering mogelijk. Gegeven de bevindingen lijken de hieraan verbonden risico's nog kleiner. Bovenstaande laat onverlet dat er ook nadelen aan het gebruik van globale beoordelingsschalen kleven. De variabiliteit tussen beoordelaars binnen stations neemt toe. Hoewel deze studie aantoont dat dit geen consequenties heeft voor de totale betrouwbaarheid is het de vraag of dergelijke argumenten overtuigend genoeg zijn voor diegenen die het examen afleggen. Studenten hebben met name kritiek op gepercipieerde verschillen tussen beoordelaars op stationsniveau. 
Een ander nadeel inherent aan de beoordelingsmethode is dat de feedback veel algemener is en mogelijk daardoor in een aantal gevallen minder informatief. 


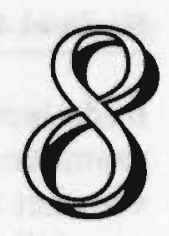

\section{EEN EMPIRISCHE VERGELIJKING TUSSEN VERSCHILLENDE METHODEN VAN CESUURBEPALING}

\section{Inleiding}

Het afnemen van (vaardigheids)toetsen maakt het noodzakelijk om een cesuur vast te stellen. Het vaststellen van normen in veel onderwijssituaties blijkt meestal een kwestie van "gezond verstand", redelijkheid en acceptabiliteit. Ook praktische toepasbaarheid kan een bepaalde keuze beïnvloeden. Met andere woorden een systematische benadering om tot een bepaalde normstelling te komen ontbreekt veelal.

Ook de ervaringen met de vaardigheidstoets zijn hier ook een voorbeeld van.

Vanaf het moment dat de vaardigheidstoets een summatieve betekenis had (curriculumjaar 1981/82) zijn diverse methoden gehanteerd voor het vaststellen van een cesuur. In de periode 1981-1984 is de normstelling van de vaardigheidstoets viermaal gewijzigd en werden bovendien verschillende normen gebruikt voor de eerste vier studiejaren en het zesde studiejaar. De onderliggende oorzaak voor deze frequente aanpassingen was grotendeels gelegen in het spanningsveld tussen absolute en relatieve normen. Beide vormen bleken in de praktijk hun voor- en nadelen te hebben en uiteindelijk hebben deze ervaringen geleid tot een compromis tussen beide beoordelingsmethoden. 
In de literatuur is weinig bekend over het vaststellen van normen bij examens (Van der Vleuten \& Swanson, 1990). In het bijzonder geldt dit voor het toetsen van vaardigheden. Vandaar dat in dit hoofdstuk verschillende normeringsprocedures worden beschreven met eventuele sterke en zwakke kanten. Hierbij wordt met name gerefereerd aan normeringsmethoden die rondom het toetsen van kennis zijn ontwikkeld.

\section{Methoden voor normbepaling}

Livingston en Zieky (1982) hebben een aantal normeringsmethoden met elkaar vergeleken. Door de methoden te groeperen kwamen ze tot een classificatie gebaseerd op een drietal niveaus van beoordeling. In de eerste plaats worden methoden onderscheiden welke gebaseerd zijn op oordelen over items. Bij deze methode van beoordeling wordt alleen uitgegaan van het inhoudelijke domein, c.q. de inhoud van items. Aan de hand van relevantie en moeilijkheidsgraad wordt een norm bepaald. Als tweede worden methoden onderscheiden gebaseerd op uitspraken over personen. Hierbij wordt primair uitgegaan van oordelen over personen in termen van voldoende en onvoldoende. Dergelijke kwalificaties worden gegeven vanuit een globaal oordeel van deskundigen met betrekking tot de beheersing van het domein. Vanuit deze kwalificaties wordt de norm bepaald.

De derde groep methoden is gebaseerd op uitspraken over een groep personen. Deze methode staat min of meer los van de inhoud van het domein. Scores worden bepaald op basis van vergelijkbaarheid van groepen bij vergelijkbaarheid van examens. Hiertoe behoren alle varianten van normeringen die gebruik maken van referentiegroepen. Bovenstaande methoden worden in de volgende paragrafen toegelicht om de meest bekende cesuurbepalingen te beschrijven.

\section{Methoden gebaseerd op oordelen over items}

De eerste drie varianten gaan uit van een persoon die net voor een toets zou slagen, een zogenaamde "borderline student". Voor elk van de varianten binnen deze methode geldt de volgende procedure: 
- het selecteren van beoordelaars; beoordelaars moeten aangeven hoe een borderline student de verschillende vragen zal beantwoorden

- het definiëren van "borderline" kennis en vaardigheden

- het trainen van beoordelaars in de gebruikte methode

- het verzamelen van oordelen van beoordelaars

- het komen tot een bepaalde cesuur.

\section{Variant 1: De methode Nedelsky}

De Nedelsky methode kan alleen maar gebruikt worden bij multiple choice examens. Het is de taak van de beoordelaar om de vraag te beoordelen en de antwoorden die een borderline student als een onjuist alternatief zou beschouwen, eruit te halen. De cesuur wordt gebaseerd op het feit dat de borderline student de multiple choice vraag beantwoordt, door eerst de foute alternatieven weg te strepen en uit de overblijvende alternatieven te raden.

\section{Variant 2: De methode Angoff}

De methode Angoff kan in tegenstelling tot de voorafgaande methode ook gebruikt worden bij andere toetsen dan multiple choice. Angoff beschouwt elke vraag als één geheel en gaat de waarschijnlijkheid na dat een borderline student een dergelijke vraag goed kan beantwoorden. De kansen op een goed antwoord worden gesommeerd en eventueel gecorrigeerd voor de raadkans om vervolgens de geschatte toetsscore en daarmee ook de norm voor de borderline student vast te stellen.

\section{Variant 3: De methode Ebel}

De methode Ebel bestaat uit twee stappen. De beoordelaars moeten eerst de vragen onderscheiden in relevantie en moeilijkheidsgraad. Relevante vragen moeten vervolgens ingedeeld worden in de categorieën essentieel, belangrijk, matig en twijfelachtig. De moeilijkheidsgraad moet vervolgens worden aangegeven in gemakkelijk, redelijk en moeilijk. Op deze wijze worden vragen ingedeeld in twaalf categorieën. Vervolgens moeten beoordelaars per categorie nagaan welk percentage vragen borderline studenten goed zullen beantwoorden. De cesuur van de test wordt bepaald aan de hand van de verwachte scores van borderline studenten per categorie. 


\section{Variant 4: De kernitem-methode}

De kernitem-methode (De Groot, 1964) behoort eveneens tot de methoden op grond van uitspraken over items. Deze methode geldt oorspronkelijk onder een aantal condities. Deze zijn als volgt:

- de gekozen examenmethode is adequaat gezien de doelstellingen van het onderwijs

- het toetsdomein bestaat een groot aantal items van het multiple choice type

- de score bestaat uit het aantal goed ingevulde vragen

- de student heeft ruim de tijd om het examen af te leggen

- het tentamen is uniek, men hoeft geen rekening te houden met andere zaken die een score zouden kunnen beïnvloeden (scores van andere jaargroepen, die een vergelijkbaar tentamen hebben afgelegd)

Bij de kernitem-methode wordt op basis van inhoudelijke argumenten bepaald of een item essentieel is voor de te beheersen en gevraagde stof. Een kernitem voldoet aan de volgende eisen (De Groot, 1964):

- het kernitem bevat essentiële leerstof in relatie tot de onderwijsdoelstelingen

- het kernitem is eenduidig qua vorm en inhoud

- het kernitem mag niet te moeilijk zijn; studenten die de stof bestudeerd en begrepen hebben moeten dit item goed kunnen beantwoorden

- het kernitem mag niet te makkelijk zijn, dat wil zeggen dat studenten die de stof niet bestudeerd hebben, kunnen het item niet goed beantwoorden

In principe worden alle gescoorde "ideale" kern-items beantwoord door alle voldoende kandidaten (gecorrigeerd voor de raadkans). Dat zal in de praktijk anders uitpakken omdat deze "ideaal typische" items niet bestaan, aangezien er nooit $100 \%$ overeenstemming zal bestaan over wat een kernitem is en wat niet. Het blijft derhalve toch min of meer discutabel op basis van welke argumenten tot een bepaalde keuze van kernitems gekomen wordt en welke norm daarvoor geldt.

$\mathrm{Bij}$ de bepaling van de kernitems in dit onderzoek is niet voldaan aan alle voorwaarden die De Groot (1964) oorspronkelijk heeft beschreven. $\mathrm{Zo}$ is de vaardigheidstoets geen multiple choice examen. Wel is voldaan aan de eis dat een kernitem eenduidig moet zijn en de essentiële stof 
moet bevatten relevant voor -in dit geval- de uitvoering van de vaardigheid.

Het voordeel van de kernitemmethode is dat inhoudsdeskundigen zich meestal goed met deze methode kunnen verenigen. Kandidaten worden beoordeeld op grond van inhoudelijke criteria die inhoudsdeskundigen zelf aangeven. De vakdeskundigheid van beoordelaars wordt volgens bepaalde regels vertaald in een bepaalde norm. Dit maakt feedback mogelijk, waardoor inhoudsdeskundigen inzicht krijgen in hoeverre onderwijsdoelstellingen behaald zijn. Een ander belangrijk voordeel van deze methode is dat onderwijsgevenden zich afvragen wat de essentie van het gegeven onderwijs is en welke eisen reëel gesteld kunnen worden aan studenten die het onderwijs volgen.

Nadeel van deze methode is de heterogeniteit in de beoordeling van inhoudsdeskundigen over wat een kernitem is en wat niet. Eveneens nadelig is dat bij iedere toets opnieuw de kernitems bepaald moeten worden hetgeen een tijdrovend gebeuren is.

Bovenstaande varianten hebben te maken met inhoud van items (relevantie, moeilijkheidsgraad). Oordelen hierover kunnen alleen maar door inhoudsdeskundigen gegeven worden. Wanneer inhoudsdeskundigen echter dergelijke oordelen geven, kan dit niet los gezien worden van het stellen van (absolute) normen. Het heeft geen zin relevantie of moeilijkheidsgraad van items aan te geven zonder dat daaraan direct consequenties worden verbonden in termen van zakken en slagen. Relevante items moeten goed gemaakt worden. Een discussie zal alleen gevoerd worden over de foutenmarge die kandidaten wordt toegestaan om relevante items niet of fout te beantwoorden. Dit betekent dat domeingerichte normeringsmethoden (zie tabel 1) altijd leiden tot absolute uitspraken over het beheersingsniveau van kandidaten.

\section{Methoden gebaseerd op uitspraken over individuele personen}

Deze methode vereist twee soorten informatie over iedere examenkandidaat; de score van de individuele kandidaat en een oordeel over het niveau aan kennis en vaardigheden van de individuele kandidaat. I) 
oordelen die binnen deze methode gevormd worden moeten aan de volgende voorwaarden voldoen:

- De oordelen moeten gevormd zijn door personen die gekwalificeerd zijn

- De oordelen moeten gebaseerd zijn op wat de toets beoogt te meten (kennis of vaardigheden)

- De oordelen moeten gebaseerd zijn op gegevens verkregen gedurende de toets

- De oordelen geven de werkelijke opinie van de beoordelaar weer.

\section{Variant 1: De borderline-group methode}

Deze variant gaat uit van de vooronderstelling dat beoordelaars borderline studenten kunnen identificeren bij het afleggen van een kennis- of vaardigheidstoets. De cesuur wordt dan de mediaan van de scores behaald door deze borderline-groep.

\section{Variant 2: De contrasting-group methode}

Deze methode gaat ervan uit dat examenkandidaten verdeeld kunnen worden in twee groepen, namelijk diegenen die geslaagd zijn en degenen die dat niet zijn. Op verschillende scoreniveau's wordt aan beoordelaars gevraagd of de meerderheid van de studenten binnen dat scoreniveau geslaagd is of niet. Voor de hogere scoreniveau's zullen beoordelaars studenten al snel in meerderheid geslaagd vinden, voor de lagere scoreniveau's geldt het omgekeerde. De cesuur wordt vastgesteld voor dat scoreniveau waarbij beoordelaars de helft van de examenkandidaten geslaagd vind en de andere helft niet.

\section{Variant 3: De up and down methode}

Deze variant gaat ervan uit dat examenkandidaten een test afleggen voordat er een beoordeling volgt in termen van voldoende/onvoldoende. Nadat kandidaten een test hebben afgelegd worden daaruit de "borderline" (net voldoende) kandidaten gehaald (ruwe inschatting). De hele test van ieder van deze kandidaten wordt vervolgens voorgelegd aan beoordelaars die op grond daarvan, een kwalificatie toekennen. Wordt een voldoende kwalificatie toegekend, dan wordt vervolgens een test van een andere kandidaat voorgelegd waarvan de resultaten slechter zijn. Dit wordt net zolang herhaald tot de grenswaarde wordt bereikt waarbij de beoordelaar een onvoldoende kwalificatie toekent. Vervolgens worden examens voorgelegd waarvan de studieresultaten beter zijn tot er 
wederom een omslagpunt wordt bereikt. Deze procedure wordt een aantal keren herhaald bij dezelfde beoordelaar. Wanneer hetzelfde omslagpunt een van tevoren vastgesteld aantal keren wordt bereikt, geldt dit punt als de cesuur.

Het nadeel van deze methode is dat het een relatief arbeidsintensieve procedure is. Bij iedere toets moeten meerdere beoordelaars worden ingeschakeld om tot een bepaalde normstelling te komen. Bovendien moet de norm per toets bepaald worden.

\section{Methoden gebaseerd op uitspraken over een groep kandidaten}

Deze varianten vinden hun oorsprong in oordelen over een (grote) groep examenkandidaten. Deze groep wordt vaak de referentiegroep genoemd. De cesuur kan hierbij worden bepaald door vast te stellen welk percentage studenten de test behoort te halen. Als de opvatting heerst dat $75 \%$ van de studenten dient te slagen voor een bepaald examen, dan wordt een zodanige cesuur gekozen dat $75 \%$ van de studenten slaagt. Het hangt van de referentiegroep af of deze methode geidentificeerd moet worden met een absolute of relatieve normstelling. Indien de referentiegroep de groep is waarop de cesuur van toepassing is, dan er is sprake van een relatieve normstelling. Hierbij wordt het zakken of slagen van een individu immers bepaald door de relatieve positie die het individu binnen de groep bekleed.

Is de referentiegroep een vergelijkbare groep die een vergelijkbaar examen heeft afgelegd, dan is er sprake van een absolute normstelling. Deze absolute norm heeft echter een andere achtergrond als die welke wordt toegepast bij de oordelen over items.

$\mathrm{Bij}$ het toepassen van deze methode moeten de volgende stappen in acht worden genomen:

- De referentiegroep moet bepaald worden

- De beoordelaars moeten worden geworven

- Voldoende en onvoldoende niveau aan kennis en vaardigheden moet worden vastgesteld 
- Het percentage examenkandidaten binnen de referentiegroep die een voldoende kennis of vaardigheidsniveau hebben moet worden vastgesteld.

Beoordelaars moeten in dit geval in staat zijn aan te geven welk percentage examenkandidaten binnen de referentiegroep een voldoende niveau aan kennis en vaardigheden heeft. Zij moeten dus goed op de hoogte zijn van wat de test meet en welk niveau kennis en vaardigheden bij de examenkandidaten verondersteld wordt.

Binnen de Faculteit der Geneeskunde wordt op een andere wijze omgegaan met het bepalen van de norm over een groep kandidaten. Hier vindt de normstelling plaats op basis van de methode "Wijnen".

\section{Variant: De methode Wijnen}

Het belangrijkste verschil met de boven omschreven methode is dat er géén beoordelaars worden ingezet om te bepalen hoeveel kandidaten uiteindelijk slagen. De methode "Wijnen" (1971) maakt gebruik van de eigen groep als referentiegroep. Een dergelijke cesuur gaat uit van de vooronderstelling dat de "gemiddelde student" genoeg tijd aan de studie besteedt. Het behaalde (jaar)groepsgemiddelde wordt derhalve het referentiepunt. Het $95 \%$ betrouwbaarheidsinterval bepaalt of een afwijking van het groepsgemiddelde als een toeval moet worden beschouwd. Derhalve worden scores van studenten buiten het gebied van het $95 \%$ betrouwbaarheidsinterval beschouwd als niet voldoende. Deze afstand komt overeen met tweemaal de standaardmeetfout. In de praktijk werkt men met de standaarddeviatie. Deze maat komt overeen met tweemaal de standaardmeetfout, wanneer de toets een betrouwbaarheid heeft van .75. Deze grens blijft echter altijd arbitrair.

Het vaststellen van normen met behulp van deze variant is in tegenstelling tot die van de item-methode, volledig losgekoppeld van de inhoud. In principe speelt het inhoudelijke domein en het absolute scoreniveau van de student geen rol. Wel relevant bij deze methode is de relatieve positie van kandidaten ten opzichte van elkaar. Dit wordt door menigeen als een nadeel beschouwd. Terecht wordt gesteld dat bij deze normstelling de cesuur geheel in handen van de groep kandidaten wordt gelegd. Docenten hebben derhalve geen "controle" over de zak/slaaggrens wat als onprettig wordt ervaren. 
Deze methode leidt tot een vast percentage onvoldoende beoordelingen, hetgeen zowel door studenten alsook door docenten als een nadeel wordt beschouwd.

Het feit dat de beoordeling min of meer los van de inhoud plaatsvindt is tegelijkertijd een groot voordeel van het werken met referentiegroepen. Discussies met betrekking tot relevantie van items en/of moeilijkheidsgraad hoeven niet gevoerd te worden. Daarnaast heeft de relatieve normering het grote voordeel dat met deze methode gecorrigeerd wordt voor onvoorspelbare zaken die tijdens een examen kunnen gebeuren. Een ander voordeel is dat een dergelijke methode corrigeert voor de moeilijkheidsgraad van een examen.

\section{Combinatie van methoden}

Er bestaan ook methodes welke uitspraken over items en uitspraken over personen met elkaar combineren. Eén van deze methoden is de methode "Hofstee" (1981) waarbij het minimale en het maximale "toelaatbare" kennisniveau van kandidaten bepaald wordt waar beneden of waar boven men geen aanpassing van de norm tolereert. Vervolgens wordt vastgesteld hoeveel onvoldoendes er moeten vallen wil de norm tot het minimum dalen. Door toepassing van een optimaliseringsformule kan men tot een normstelling komen waarbij kennis- en zakpercentages aan elkaar zijn gerelateerd.

Ook de door onszelf gehanteerde methode bij de reguliere vaardigheidstoets is een combinatie van absolute en relatieve normering. Hierbij wordt de uitslag van studenten bepaald aan de hand van het gemiddelde en de standaarddeviatie.

Tabel 1: Overzicht van de verschillende benaderingen om tot een normstelling te komen.

\begin{tabular}{|c|c|c|}
\hline Methoden & Interpretatie van scores & Type cesuur \\
\hline Beoordelen van items & Domeingeoriënteerd & Absoluut \\
\hline Beoordelen van personen & Normgeoriënteerd & Relatief \\
\hline Beoordelen van groepen & Normgeoriënteerd & Absoluut of Relatief \\
\hline Beoordeling items/groepen & Domein-en normgeoriënteerd & $\begin{array}{l}\text { Absoluut en Relatief } \\
\text { (Compromismethode) }\end{array}$ \\
\hline
\end{tabular}

Ligt echter de gemiddelde score van een student verminderd met een halve standaarddeviatie boven een (gewogen) goedscore van $70 \%$ dan heeft de student altijd een voldoende. Heeft de student daarentegen een 
gemiddelde (gewogen) score verminderd met een hele standaarddeviatie die lager uitvalt dan $55 \%$, dan wordt altijd de kwalificatie onvoldoende gegeven.

Uit het bovenstaande blijkt dat de verschillende normeringsmethoden nauw gerelateerd zijn aan een absolute of relatieve cesuur. Oordelen over items zullen meestal leiden tot absolute uitspraken met betrekking tot het hebben van een voldoende beheersingsniveau. Dit komt omdat het beheersingsniveau op basis van relevante inhoudelijke items wordt beoordeeld. Wanneer deze items eenmaal bepaald zijn, zullen beoordelaars de neiging hebben de norm hier rechtstreeks aan te ontlenen. Men noemt dit ook wel een "domeingeoriënteerde" benadering.

Bij uitspraken over personen worden kwalificaties in termen van voldoende en onvoldoende ook gerelateerd aan de inhoud van de stof. Evenals bij de methode gebaseerd op "uitspraken over items" zal men hier geneigd zijn te kiezen voor een absolute norm. Uitspraken komen echter mede tot stand door vergelijkingen tussen personen op basis van de geleverde prestatie. Dit is een vorm van relatief normeren, wat mogelijk kan leiden tot aanpassingen van de absolute norm.

De methoden gebaseerd op uitspraken over groepen zijn uitspraken gebaseerd op vergelijkingen. Afhankelijk van het soort vergelijking kunnen normstellingen absoluut of relatief worden bepaald.

Tabel 1 geeft een samenvattend overzicht van de verschillende gebruikte terminologieën en benaderingswijzen.

\section{Probleemstelling}

In het voorafgaande zijn een aantal methoden beschreven om tot een normstelling te komen. Voor een vaardigheidstoets zijn de beschreven methoden niet allen even bruikbaar. Zo lijkt de beschreven methode gebaseerd op oordelen over items (Angoff, 1971), minder geschikt om toegepast te worden. Het lijkt praktisch moeilijk haalbaar om een complete vaardigheidstoets bestaande uit gemiddeld 250-300 items door eenzelfde groep personen te laten beoordelen op relevantie en deze procedure voor iedere toets opnieuw uit te voeren. De overige beschreven methoden lijken wel toepasbaar bij vaardigheidstoetsing. 
Binnen dit onderzoek wordt nagegaan of de verschillende benaderingen die wel mogelijk en haalbaar lijken, leiden tot grote verschillen in zak/slaag grenzen.

\section{Methode}

\section{Materiaal}

De verschillende methoden om tot een normstelling te komen zijn toegepast op gegevens van de zesdejaars toets in het curriculumjaar 89/90. Deze toets bestond uit een viertal stations per circuit. Er waren twee circuits. In totaal hebben 70 kandidaten aan deze toets deelgenomen. Er waren 46 verschillende (co)observatoren bij betrokken.

\section{Procedure}

Van elke klasse van methoden is minimaal één variant genomen om tot de uiteindelijke vergelijking tussen verschillende normstellingen te komen. De kernitemmethode is geselecteerd uit de klasse van methodes betreffende uitspraken over items en kende de volgende varianten:

Variant A: De inhoud van de items die door $50 \%$ van de beoordelaars als kernitem worden aangegeven moeten allen door de student goed uitgevoerd worden, (absolute norm van 100\%) gecorrigeerd voor tweemaal de standaardmeetfout. Deze correctie bedraagt ongeveer $15 \%$ zodat de uiteindelijke norm op $85 \%$ ligt.

Variant B: De inhoud van de items die door $80 \%$ van de beoordelaars als kernitem worden aangegeven moeten allen door de student goed verricht worden, (absolute norm van 100\%) zonder correctie voor de standaardmeetfout.

Variant $C: B i j$ het toepassen van de absolute norm is als voldoende/onvoldoende grens $70 \%$ van de gewogen goed score genomen. Dit is de score die gehanteerd wordt bij de herkansing van de vaardigheidstoets. Deze norm is oorspronkelijk gebaseerd op de inhoud van de vaardigheidstoets, waarbij gesteld werd dat een score van $70 \%$ ruim voldoende was (vergelijk de 10-puntscijferlijst van de middelbare school). 
Voor de methode gebaseerd op uitspraken over personen is de "up and down" methode gekozen (variant D).

Variant D: Hierbij werd de totale vaardigheidstoets van een student aan een inhoudsdeskundige voorgelegd en deze beoordelaar moest vervolgens aangeven of de desbetreffende student in zijn ogen over het totale examen (alle criterialijsten) voor een voldoende kwalificatie in aanmerking komt of niet. Als de kwalificatie werd toegekend (voldoende respectievelijk onvoldoende) dan kreeg de beoordelaar zonder daarvan op de hoogte te zijn- een kandidaat met een 5\% lagere respectievelijk hogere score. Dit gaat zo door tot de toegekende kwalificatie verandert: het omslagpunt. Wanneer een dergelijk omslagpunt driemaal op hetzelfde niveau (bij hetzelfde percentage) plaatsvond werd dat omslagpunt genomen als de norm behorend bij die specifieke beoordelaar.

Als startpunt werd genomen een student met de gemiddelde toetsscore $(67 \%)$ van de jaargroep. In totaal hebben twaalf verschillende inhoudsdeskundigen samen 98 kandidaten beoordeeld. Van deze twaalf beoordelaars zijn er zes werkzaam binnen de eerste lijn en zes werkzaam binnen de tweede lijn. De gemiddelde grenswaarde werd berekend door de som te nemen van de gemiddelden van het interval en dit te delen door het totaal aantal intervallen (12). Deze gemiddelde grenswaarde bleek $62 \%$ te zijn.

De methode gebaseerd op uitspraken over groepen wordt geilllustreerd aan de hand van de methode "Wijnen" (1971).

Variant E: Elk item van de vaardigheidstoets krijgt één punt wanneer dat betreffende item juist is uitgevoerd. Gezien de relevantie van bepaalde items wegen sommige items zwaarder dan anderen. De uiteindelijke score wordt derhalve bepaald aan de hand van de goede items, rekening houdend met de weegfactoren (gewogen goed score). Bij de methode Wijnen wordt de gemiddelde gewogen toetsscore minus twee maal de standaardmeetfout (standard error of measurement) als cesuur genomen.

Bij de combinatiemethode over items en groepen zijn meerdere varianten gebruikt (varianten $F$ en $G$ ). 
Variant F: Bij de relatieve norm zoals die bij de vaardigheidstoets wordt toegepast ligt de voldoende/onvoldoende cesuur op het gewogen gemiddelde over alle items van de vaardigheidstoets minus de standaarddeviatie. Eveneens wordt de kwalificatie "twijfelachtig" gegeven. Deze kwalificatie betekent dat er onvoldoende informatie bestaat over de student om een oordeel te vellen. In praktische zin wordt deze kwalificatie geïnterpreteerd als "niet voldoende". De grens van de twijfelachtige kwalificatie norm ligt in tussen de voldoende en onvoldoende score. In hoofdstuk 3 is gedetailleerd beschreven op basis van welke criteria de kwalificaties tot stand komen.

Variant G: De variant volgens de methode Hofstee. Hiervoor geldt de formule $\mathrm{Kmin}+\mathrm{a} \cdot \mathrm{z}=\mathrm{Kmax}(\mathrm{K}=$ kennispercentage, $\mathrm{z}=$ zakpercentage, $\mathrm{a}$ $=$ constante). Zoals eerder vermeld wordt bij de methode Hofstee het minimale en het maximale "toelaatbare" kennisniveau van kandidaten bepaald zonder dat men de norm aanpast. Voor de vaardigheidstoets geldt volgens het Examenreglement van de faculteit der geneeskunde dat een gemiddelde gewogen totale toetsscore beneden de $55 \%$ een onvoldoende kwalificatie oplevert $(\mathrm{Kmin}=55 \%)$. Eveneens geldt dat alle waarden boven de $70 \%$ een voldoende kwalificatie moeten opleveren $(\mathrm{Kmax}=70 \%)$. Vervolgens stelt men vast hoeveel onvoldoendes er moeten vallen wil de norm tot het minimum dalen. In ons geval is op arbitraire gronden gekozen voor een percentage van $60 \%$ Op deze manier kan de parameter a worden berekend uit de formule $55+\mathrm{a} \cdot 60=$ 70. De parameter is in dit geval 1/4. Door toepassing van dit gegeven in de formule $k+a z, k \geq 55$, waarbij $a=1 / 4$ kan men tot een normstelling komen waarbij kennis- en zakpercentages aan elkaar zijn gerelateerd.

\section{Statistische analyse}

Binnen dit onderzoek werd gebruik gemaakt van de beschrijvende statistiek. De mate van overeenstemming tussen beoordelaars werd bepaald aan de hand van Cohen's kappa (Cohen, 1960). Een kappa van .80 wordt als adequaat beschouwd. 


\section{Resultaten}

Observatoren hebben per station aangegeven in hoeverre items van stations gerekend mogen worden tot kernitems. Om een indruk te krijgen van de mate van overeenstemming tussen beoordelaars over welke items als kernitems beschouwd worden is een kappa berekend per station (zie tabel 2).

Uit deze tabel blijkt dat de overeenstemming tussen beoordelaars $(\mathrm{N}=52$; minimaal vier beoordelaars per station) erg laag is. De hoogste kappa's worden bereikt voor het domein gynaecologie/verloskunde. In het domein waarbinnen de meest globale items voorkomen, $\mathrm{KNO} / \mathrm{Oog}$ worden hele lage kappa's worden gevonden. Dit is conform de verwachting dat verschillen tussen beoordelaars bij globale lijsten groter zijn dan bij analytische lijsten (zie ook hoofdstuk 7).

Tabel 2: Overeenstemming tussen beoordelaars $(N=52)$ per station over de aanwezigheid van kermitems

\begin{tabular}{llcc}
\hline Ronde & Inhoud & N items & Kappa \\
A & Gynaecologie / Verloskunde & 37 & .31 \\
B & Gynaecologie / Verloskunde & 31 & .30 \\
A/B & Sociale Vaardigheden & 32 & .24 \\
A & Bewegingsapparaat & 78 & .11 \\
B & Bewegingsapparaat & 85 & .14 \\
A & KNO/Oog & 12 & .02 \\
B & KNO/Oog & 14 & .13 \\
A & Kindergeneeskunde & 43 & .18 \\
B & Kindergeneeskunde & 46 & .22 \\
\hline
\end{tabular}

Tabel 3 geeft een overzicht van de aantallen kernitems per station. Hierbij is een onderscheid gemaakt tussen items die meer dan de helft van de observatoren als kernitem beschouwde en items waarvan alle observatoren op één na vonden dat er sprake was van een kernitem. Als het oorspronkelijk aantal items vergeleken wordt met het aantal door de meerderheid van de beoordelaars - aangegeven kernitems blijkt dat vrij systematisch per station ongeveer één derde van het aantal items niet in aanmerking komt als kernitem. Wanneer echter een vrijwel volledige unanimiteit van beoordelaars wordt geëist, blijkt nog eens één derde van het aantal items af te vallen. In totaal blijft in dat geval ongeveer één derde van het oorspronkelijk aantal items over van het 
totaal en van de afzonderlijke stations, ongeacht de verschillende inhoudsgebieden per station.

Tabel 3: Aantallen kemitems per station aangewezen door minimaal de helft of door minimaal alle observatoren minus één (i.h.a. meer dan $80 \%$ overeenstemming).

Ronde Inhoud

A Gynaecologie/Verloskunde

B Gynaecologie/Verloskunde

A/B Sociale Vaardigheden

A Bewegingsapparaat

B Bewegingsapparaat

A $\mathrm{KNO} / \mathrm{Oog}$

B $\mathrm{KNO} / \mathrm{Oog}$

A Kindergeneeskunde

B Kindergeneeskunde

Totaal
Aantal Overeenstemming Overeenstemming items $\quad \geq 50 \% \quad \geq 80 \%$

$\begin{array}{rrr}37 & 24 & 14 \\ 31 & 19 & 11 \\ 32 & 17 & 11 \\ 78 & 65 & 30 \\ 90 & 75 & 31 \\ 12 & 09 & 1 \\ 14 & 14 & 5 \\ 43 & 25 & 12 \\ 46 & 27 & 15 \\ 383 & 275 & 130\end{array}$

In tabel 4 staan de zak/slaaggrenzen en de percentages voldoenden en onvoldoenden vermeld voor de diverse normeringsmethoden. Hierbij worden tevens diverse variaties binnen en tussen cesuren met elkaar vergeleken.

Uit de tabel blijkt dat er grote verschillen zijn in zak/slaag percentages wanneer men (varianten van) de verschillende methoden toepast. Niemand slaagt wanneer alle kernitems goed verricht moeten zijn. Let wel dit zijn items die door alle beoordelaars minus eén als zeer essentieel voor de handeling worden beschouwd. Wanneer men deze norm corrigeert voor (tweemaal) de standaardmeetfout dan slaagt nog maar $11 \%$ van de studenten (variant $\mathrm{A}$ ).

Op inhoud gebaseerde oordelen over items die in absolute termen worden gehanteerd leiden tot veel hogere percentages onvoldoendes dan alle andere normeringsmethoden. Daarentegen zijn oordelen gebaseerd op uitspraken over groepen en niet aan inhoud gebonden het meest mild voor kandidaten. Alle andere methoden bevinden zich tussen deze twee uitersten qua zak/slaag percentages, zoals de eveneens inhoudelijk beoordelende "up and down" methode en de combinatiemethode over items en groepen. 
Tabel 4: Een vergelijking tussen drie verschillende klassen van cesururmethoden en een combinatie van methoden bij de zesdejaars vaardigheidstoets voor wat betrefi de zak/slaaggrenzen en de percentages voldoenden en onvoldoendes.

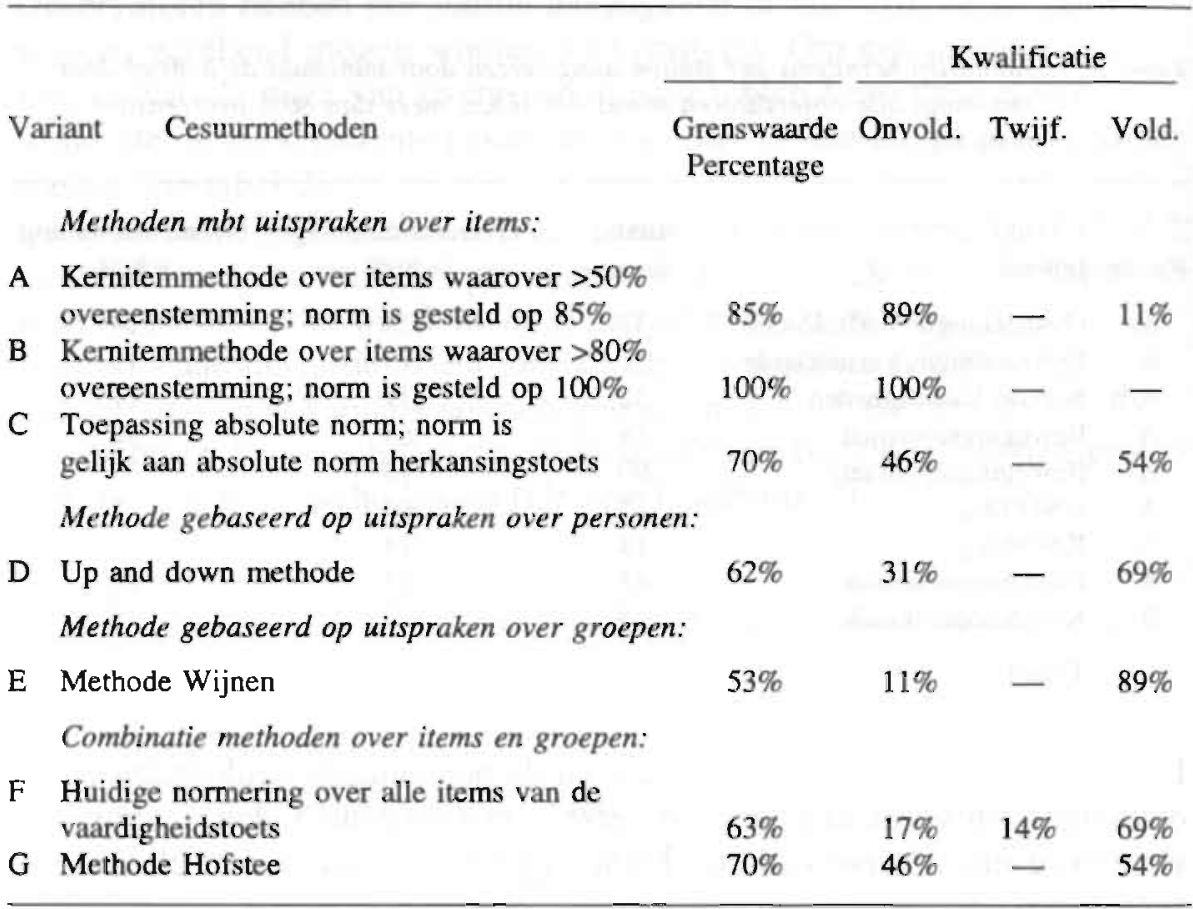

\section{Discussie}

In dit hoofdstuk worden meerdere methoden besproken om tot een bepaalde normstelling te komen. De vraag blijft op grond van welke argumenten een bepaalde normering de voorkeur verdient.

Er zijn een drietal klassen van normeringsmethoden aan de orde geweest. Acht men het essentieel dat de inhoud van de leerstof maximaal betrokken wordt bij het bepalen van de cesuur dan zal men al snel overgaan tot methoden gebaseerd op uitspraken over items. Het grote voordeel van dergelijke methoden is dat men zich in de cesuurbepaling duidelijk richt op de inhoud de toets. Daarnaast biedt het de mogelijkheid, dat alle studenten kunnen slagen indien ze het domein 
goed beheersen. Een voordeel is eveneens dat een dergelijke normeringsmethode erg inzichtelijk is. Er zijn echter duidelijke nadelen. Uit deze studie blijkt dat er weinig consensus bestaat tussen inhoudsdeskundigen over wat essentieel gevonden wordt binnen de leerstof. De relevante items waarover beoordelaars het wel eens zijn worden door geen van de studenten alle goed gemaakt. Dit is evident onacceptabel en getuigt van een zwakke validiteit van de methode. Overigens wordt de indruk van observatoren nogmaals bevestigd dat er relatief veel minder relevante items in de vaardigheidstoets zitten (zie hoofdstuk 6).

Een cesuurbepaling gebaseerd op uitspraken over items houdt geen rekening met andere factoren die een toetsuitslag nadelig kunnen beïnvloeden zoals slecht of niet gegeven onderwijs, onduidelijke items, organisatorische onvolmaaktheden en dergelijke. Fouten in dat opzicht worden afgewenteld op de rug van de kandidaat.

Uiteindelijk zouden dergelijke omstandigheden zelfs kunnen leiden tot het zakken van alle kandidaten.

De methode gebaseerd op referentiegroepen is in zekere zin tegengesteld aan de voorafgaande methode. Hierbij speelt de inhoud van het examen geen essentiële rol, wel de relatieve positie van de getoetste kandidaten ten opzichte van anderen. Deze relatieve positie kan in absolute of relatieve zin worden bepaald. Wanneer de criteriumgroep de eigen jaargroep is, op de wijze zoals dat bij de vaardigheidstoets aan de faculteit der geneeskunde gebeurt, dan is de relatieve positie van de kandidaat gebaseerd op de relatieve norm. Wanneer er sprake is van een externe criteriumgroep worden scores van deze groep vaak in absolute zin gebruikt om de positie van de kandidaat te bepalen. In het laatste geval blijft echter sprake van een relatieve normering. Het voordeel van een dergelijke normeringsmethode is dat rekening gehouden wordt met eerder genoemde variabelen die een toetsuitslag onbedoeld kunnen. beïnvloeden.

Het feit dat er geen rekening gehouden wordt met de inhoud van de toets wordt door menigeen als een belangrijk nadeel gezien. Eveneens bestaat bij relatieve methoden, die gebaseerd zijn op een relatieve norm het nadeel dat er altijd een vast percentage van de kandidaten niet aan de cesuur voldoet. Tevens blijkt in de praktijk dat studenten het nadelig vinden dat de norm altijd achteraf wordt bepaald.

Methoden gebaseerd op uitspraken over personen betrekken zowel de inhoud in de beoordeling (moeilijkheidsgraad en relevantie van items) 
alsook de vergelijkbaarheid van het individu ten opzichte van anderen (de groep personen die niet "borderline" zijn cq de groep met een iets hogere of lagere score). Het nadeel van deze methode is dat de norm hier pas achteraf vastgesteld kan worden en dat de methode erg arbeidsintensief is en dus niet praktisch.

De combinatiemethode komt tegemoet aan de nadelen van beide methoden, waardoor het een aantrekkelijke methode is. Bij de combinatiemethode wordt rekening gehouden wordt met de domeingerichte visie doordat beneden een bepaald percentage iedereen onvoldoende heeft, maar ook boven een bepaald percentage iedereen een voldoende kan behalen. Correcties blijven echter mogelijk binnen een beperkt gebied waarvan verondersteld wordt dat daar de cesuur komt te liggen. Een nadeel is, zeker bij de methode Hofstee, dat het komen tot de norm voor vele betrokkenen ondoorzichtig is.

Het onderzoek laat duidelijk zien dat het toepassen van de verschillende methoden om te komen tot een normstelling tot nogal verschillende resultaten kan leiden in aantallen zak/slaag beslissingen. Het aantal geslaagden varieert in deze studie van nul procent tot negentig procent. Hoewel dit extremen zijn geeft dit wel aan dat het stellen van normen een zorgvuldige benadering vereist omdat de consequenties groot belang kunnen zijn.

Welke methode tot de meest valide beslissingen leidt is vooralsnog onduidelijk.

Inhoudelijk gerichte methoden stellen erg hoge eisen aan kandidaten en zijn wellicht te streng. Relatieve oordelen zijn vaak milder voor de kandidaat, wellicht te mild. Op dit moment lijken compromismethoden de voorkeur te verdienen. Verder onderzoek naar de validiteit van de verschillende methoden zou echter zeer wenselijk zijn. 


\section{DE PREDICTIEVE VALIDITEIT VAN DE VAARDIGHEIDSTOETS VOOR DE KLINISCHE STAGES}

\section{Inleiding}

Uit hoofdstuk twee blijkt dat er tot nu toe weinig bekend is over de predictieve validiteit van stationsexamens voor het toekomstig functioneren binnen de gezondheidszorg. Met betrekking tot de vaardigheidstoets bleek in een eerder uitgevoerd pilot onderzoek dat er een sterk verband bestond tussen vaardigheidstoetsuitslagen van de eerste vier studiejaren en succes in de stages in het vijfde en zesde studiejaar (l'Espoir e.a, 1987). Dit verband bleek bij de algemeen medische kennistoets aanmerkelijk lager te zijn. De uitkomsten van dit onderzoek waren echter gebaseerd op een gering aantal data. Eveneens is de inhoudelijke samenstelling van de vaardigheidstoets in de jaren 5 en 6 veranderd ten opzichte van vroeger (zie hoofdstuk 3 ). Beide gegevens waren aanleiding om de predictieve waarde van de vaardigheidstoets opnieuw te onderzoeken. Als er een verband bestaat tussen de vaardigheidstoets en later functioneren in de praktijk dan zal dat verband in ieder geval ook aantoonbaar moeten zijn voor de resultaten van de vaardigheidstoets in de eerste vier studiejaren ten opzichte van de laatste twee studiejaren, de periode waarin de student door middel van coassistentschappen kennismaakt met de praktijk van de gezondheidszorg. Uitkomsten hiervan zullen worden afgezet tegen de predictieve waarde van de algemeen medische kennistoets (voortgangstoets, zie hoofdstuk $3)$. 
In de literatuur worden diverse -soms strijdige- resultaten vermeld over de voorspellende waarde van toetsresultaten binnen de medische opleiding voor later functioneren. Carswell (1987) vond een significant verband tussen toetsen die gedurende het medische curriculum zijn afgenomen en het laatste zogenaamde "final examination". In de conclusies wordt dan ook vermeld dat één beslissend laatste (eind)examen overbodig lijkt.

Warrick \& Cumrine (1986) vonden daarentegen een significante negatieve correlatie tussen de "National Board Examinations" en de toetsen die gebruikt worden binnen de opleiding tot anesthesist. In tegenstelling tot dit resultaat laat een uitgebreid onderzoek betrekking hebbend op dezelfde "National Board Examinations" zien dat voor alle andere opleidingen wel een sterk verband bestaat tussen Examenresultaten en later functioneren als arts-assistent voor zover het kennisaspecten betreft (Turner et al., 1987).

Met betrekking tot stationsexamens geeft Vu (1993) aan dat de Standardized Patient-based testen een goede voorspeller zijn voor later functioneren in het medisch beroep.

Concluderend kan men stellen dat examenresultaten een zekere predictieve waarde hebben, maar dat dit verband zelden sterk is en met betrekking tot stationsexamens nauwelijks is bestudeerd.

\section{Probleemstelling en verwachtingen}

Gezien de relevantie van de vaardigheids- en voortgangstoets voor de studievoortgang van studenten is de vraag relevant of de hoogte van de scores op vaardigheidstoetsen en voortgangstoetsen voorspellend zijn voor het al dan niet succesvol doorlopen van de stages.

Aangezien vaardigheidstoetsen en voortgangstoetsen verschillende competenties beogen te meten wordt verwacht dat de correlaties binnen vaardigheidstoetsen en voortgangstoetsen afzonderlijk sterker zijn dan tussen deze meetinstrumenten. De correlaties tussen de meetinstrumenten zullen naar verwachting echter wel sterker worden naarmate studenten verder zijn in hun studie (Van der Vleuten et al., 1989-C). In de laatste twee studiejaren worden studenten beoordeeld op verschillende aspecten van medische competentie resulterend in één eindbeoordeling per stage. De eindbeoordeling komt mede tot stand op 
basis van gebleken kennis- en vaardigheidsaspecten van de student tijdens de stage. Het lijkt aannemelijk te veronderstellen dat het vaardigheidselement binnen de stagebeoordeling een sterker verband laat zien met vaardigheidstoetsuitslagen dan met voortgangstoetsuitslagen.

Figuur 1: Modelmatige weergave van verbanden tussen resultaten behaald op de vaardigheidstoets, voortgangstoets en stagebeoordelingen. De resultaten op de toetsen zijn de geobserveerde variabelen. De vaardigheid, de kennis en het praktisch handelen zijn de latente variabelen.

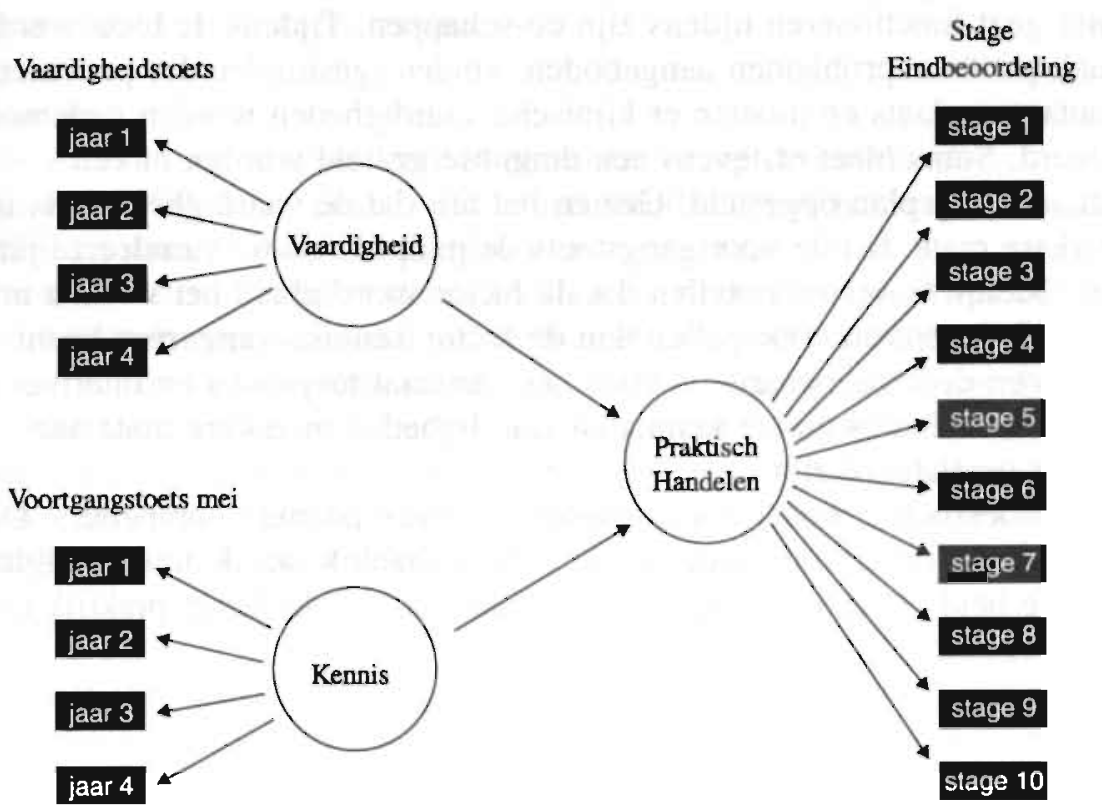

Een cirkel geeft een latente variabele aan.

Een vierkant geeft de geobserveerde variabelen aan.

Omgekeerd zal het kenniselement van de stages een sterkere samenhang vertonen met de voortgangstoets dan met de vaardigheidstoets. De verbanden tussen vaardigheidstoets, voortgangstoets en stagebeoordelingen kunnen modelmatig als volgt in een causaal verband worden weergegeven (figuur 1).

Het geschetste causale model bestaat uit drie factoren, namelijk onderliggende variabelen die geobserveerde correlaties kunnen verklaren. 
De laatst afgenomen voortgangstoets per jaargroep (de "mei-toets") werd genomen voor de eerste vier studiejaren voor de meting van de onderliggende factor (latente variabele) "kennis".

Alle (vier) vaardigheidstoetsen van de eerste vier studiejaren werden genomen voor de meting van de onderliggende factor (latente variabele) "vaardigheid".

Alle stagebeoordelingen vormen de onderliggende factor voor "handelen in de praktijk". Zowel kennis als vaardigheid zijn voorwaarden voor adequaat handelen in de praktijk. De situatie waarin een student getoetst wordt bij de vaardigheidstoets lijkt sterk op de situatie waarin de student later gaat functioneren tijdens zijn co-schappen. Tijdens de toets worden vaak patiëntenproblemen aangeboden, vinden (gesimuleerde) patiëntencontacten plaats en moeten er klinische vaardigheden worden gedemonstreerd. Soms moet er tevens een diagnose gesteld worden of een behandelingsplan opgesteld. Gezien het feit dat de vaardigheidstoets in sterkere mate dan de voortgangstoets de praktijksituatie simuleert lijkt het redelijk te veronderstellen dat de factor vaardigheid het werken in de praktijk beter zou voorspellen dan de factor kennis. Aangezien kennis voor een deel voorwaarde is voor het adequaat toepassen en interpreteren van vaardigheden zullen kennis en vaardigheden in zekere mate aan elkaar gerelateerd zijn.

Het onderzochte model is een model met twee latente voorspellers. Door middel van deze modelspecificatie is het mogelijk om de unieke bijdrage van de beide latente voorspellers ten aanzien van de factor praktijk te onderzoeken.

\section{Methode}

\section{Instrumenten}

De gekozen meetinstrumenten zijn voor de eerste vier studiejaren ten opzichte van de laatste twee studiejaren verschillend. Voor de eerste vier studiejaren geldt dat gekozen is voor alle vaardigheidstoetsuitslagen in deze studiejaren. Aangezien er én vaardigheidstoets per jaar wordt afgenomen betekent dit vier toetsuitslagen in totaal.

Van dezelfde studenten is ook steeds per jaar de uitslag genomen van de laatste voortgangstoets per jaargroep per jaar (mei-toets). Dit werd gemotiveerd doordat deze voortgangstoetsen het dichtst liggen bij het 
moment van afname van de vaardigheidstoets en derhalve het best vergelijkbaar zijn, en ook omdat deze voortgangstoetsen (in ieder geval voor de eerste vier studiejaren) het zwaarste wegen in de beslissing omtrent studievoortgang.

De stagebeoordelingen vormen het criteriuminstrument. Aan het eind van elke stage krijgt de student een stagebeoordeling. Er zijn in totaal tien verplichte stages. Hierbij zijn, voor zover aanwezig, alle scores genomen van de tien stagebeoordelingen voor wat betreft kennisbeoordeling, vaardigheidsbeoordeling en de totale eindbeoordeling en tevens de gemiddelde eindbeoordelingen van kennis, vaardigheden en globale indruk over de tien stages samen.

\section{Subjecten}

In deze studie zijn die studenten betrokken die op de peildatum december 1990 als zesdejaars studenten stonden ingeschreven. Het aantal zesdejaars studenten op die peildatum bedroeg 183 .

Studenten die 5 of minder stages hadden doorlopen dan wel twee of meer voortgangstoetsen en/of vaardigheidstoetsen niet hadden afgelegd zijn uit het onderzoek verwijderd. De berekeningen zijn uitgevoerd over het resterende aantal studenten (122). Aangezien de instroom in het zesde studiejaar zich met name concentreerd rond de periode augustus, ligt het niet in de verwachting dat deze selectie invloed heeft op de resultaten van het onderzoek.

\section{Procedure}

Voor alle toetsscores geldt dat de score van het eerste toetsmoment (voortgangstoets, vaardigheidstoets) $\mathrm{cq}$ kwalificatie (stagebeoordeling; zie later) is genomen van elke student. Dit betekent dat indien een student een jaar herhaalt de oorspronkelijke score is genomen en niet de score van het herhaalde jaar. Dit geldt zowel voor de voortgangstoets alsook voor de vaardigheidstoets.

Het is onduidelijk of deze procedure ten aanzien van de studievertragers de kwaliteit van de verzamelde gegevens heeft beïnvloed.

De scores die gebruikt worden in de berekeningen zijn voor de diverse instrumenten verschillend. Dit komt omdat zak/slaagbeslissingen voor de verschillende meetinstrumenten op verschillende wijze worden berekend. Voor de vaardigheidstoets wordt uitgegaan van het percentage goed gescoorde items (na correctie voor weging). Bij de voortgangstoets wordt uitgegaan van de procentuele goed minus foutscore. 
In zes gevallen ontbrak een waarneming van de mei (voortgangs)toets. Dit zijn studenten die om verschoonbare redenen de toets niet hebben afgelegd, bijvoorbeeld omdat er een buitenlandse stage werd doorlopen. In die gevallen is de score van de voortgangstoets in maart genomen aangezien dit nog de dichtstbijzijnde waarde is voor de score op de mei toets en er hoge verbanden bestaan tussen twee opeenvolgende toetsen. In de berekeningen zijn vervolgens de goed minus foutscores per student per jaargroep omgezet in percentielscores. Gezien het karakter van de voortgangstoets (einddoelgerichte toetsing; zie hoofdstuk 3) was deze omzetting noodzakelijk om scores van studenten in verschillende jaren met elkaar te kunnen vergelijken.

De stagebeoordelingen worden weergegeven op driepuntsschalen voor wat betreft de kennis- en vaardigheidsbeoordeling in de stage, waarbij onvoldoende als één punt gerekend wordt, twijfelachtig als twee punten en voldoende als drie punten. Het eindoordeel van de stage werd uitgedrukt op een vijfpuntsschaal waarbij "onvoldoende" de waarde één kent, "twijfelachtig" de waarde twee, "voldoende" de waarde drie, "goed" de waarde vier en "zeer goed" de waarde vijf.

Stagebeoordelingen die niet aanwezig waren werden niet in de berekeningen meegenomen. Gezien de grote samenhang tussen stagebeoordelingen lijkt dit van weinig invloed. Temeer daar het maximaal aantal niet doorlopen stages binnen deze studie slechts vier bedraagt.

\section{Statistische analyse}

Eerst zullen beschrijvende statistieken ten aanzien van de diverse meetinstrumenten vermeld worden.

Om te beoordelen welk verband er bestaat tussen scores op de vaardigheidstoets en voortgangstoets enerzijds met stagebeoordelingen anderzijds werden correlationele verbanden berekend.

Door middel van de Lisrel analyse (Jöreskog \& Sörbom, 1981) kunnen empirische data met een gepostuleerd model vergeleken worden. Op deze manier kan worden nagegaan of de data voldoende gerepresenteerd worden door de latente variabelen. Vervolgens kon worden nagegaan of de relatie tussen de latente variabelen past bij het gepostuleerde model (latente structuuranalyse). Verschillende statistische grootheden worden hiervoor gebruikt. Hierbij wordt de correlatiematrix van het hypothetische model vergeleken met de correlatiematrix van de geobserveerde data. Ligt het verschil tussen deze twee matrices beneden een bepaalde criteriumwaarde (chikwadraat/df ratio kleiner dan 2), dan mag worden 
aangenomen dat de data kunnen worden beschreven vanuit het hypothetisch model. Hierbij mag dan géén sprake zijn van een significant verschil.

Om te beoordelen of het model past wordt behalve deze parameters nog gekeken naar de proportie door het model verklaarde variantie: hoe meer variantie door het gepostuleerde model wordt verklaard, hoe beter de voorspelling is.

Tevens wordt de Goodness-of-Fit Index en de Adjusted Goodness-of-Fit Index bepaald om te kijken of een model past of niet. Deze maten hangen samen met de proportie niet verklaarde variantie. Voor de Adjusted Goodness-of-Fit Index wordt gecorrigeerd voor het aantal vrijheidsgraden. De waarden bij een goed passend model liggen voor beide indices boven de .80 .

Tabel 1: Beschrijvende statistieken van de scores van vaardigheidstoetsen, voortgangstoetsen voor de studiejaren 1 tot en met 4 (in procenten) en de gemiddelde eindbeoordeling van de kwalificaties voor de doorlopen stages met betrekking tot het kennis-en vaardigheidsniveau (drie-puntsschaal; onvoldoende $=1 ;$ twiffelachtig $=2 ;$ voldoende $=3$ ) en voor de eindbeoor deling van de stages (viff-puntsschaaal; 1 = onvoldoende, 2 = twiffelachtig, $3=$ voldoende, $4=$ goed, $5=$ zeer goed) over studiejaar 5 en 6 .

\begin{tabular}{|c|c|c|c|c|c|}
\hline \multicolumn{2}{|c|}{ Soort toets } & Gemiddelde & $\begin{array}{c}\text { Standaard } \\
\text { deviatie }\end{array}$ & Minimum & Maximum \\
\hline \multicolumn{6}{|c|}{ Vaardigheidstoets } \\
\hline Jaar & 1 & 78.17 & 7.55 & 48.00 & 93.00 \\
\hline Jaar & 2 & 72.12 & 10.74 & 38.00 & 90.00 \\
\hline Jaar & 3 & 73.82 & 8.83 & 37.00 & 93.00 \\
\hline Jaar & 4 & 78.64 & 9.57 & 18.00 & 94.00 \\
\hline \multicolumn{6}{|c|}{ Voortgangstoets } \\
\hline Jaar & 1 & 10.31 & 3.77 & 2.00 & 23.00 \\
\hline Jaar & 2 & 15.29 & 6.13 & 4.00 & 39.00 \\
\hline Jăar & 3 & 19.59 & 7.01 & 4.00 & 51.00 \\
\hline Jaar & 4 & 30.54 & 10.10 & 3.00 & 66.00 \\
\hline \multicolumn{6}{|c|}{ Stagebeoordelingen } \\
\hline Kenni & & 2.97 & 0.08 & 2.38 & 3.00 \\
\hline Vaard & & 2.99 & 0.03 & 2.78 & 3.00 \\
\hline Eindo & 1 stage & 3.44 & 0.25 & 3.00 & 4.10 \\
\hline
\end{tabular}




\section{Resultaten}

In tabel 1 wordt een overzicht gegeven van de beschrijvende statistiek voor wat betreft de scores op de vaardigheidstoets, scores op de voortgangstoets en de kwalificaties met betrekking tot de eindbeoordelingen op de stages.

In de eerste plaats is te zien dat de scores van de vaardigheidstoets een stuk hoger liggen dan die van de voortgangstoets. Dit is verklaarbaar doordat de vaardigheidstoets inhoudelijk het hele (veel kleinere) domein meet wat een student in zijn onderwijs aangeboden heeft gekregen. Bovendien is dit domein voor een belangrijk deel nauwkeurig beschreven door middel van standaarden (hoofdstuk 1). Dus een student kan in principe bij de vaardigheidstoets alles weten (kunnen). Bij de voortgangstoets is dit anders. Het domein is veel groter en bovendien zijn de eindtermen met betrekking tot kennis niet zo specifiek beschreven als voor vaardigheden. Tevens gaat de vaardigheidstoets alleen uit van de (gewogen) goedscore. $\mathrm{Bij}$ de voortgangstoets worden de foute antwoorden van de goedscore afgetrokken. Bovenstaande verklaart eveneens waarom de scores op de vaardigheidstoets redelijk stabiel zijn over de jaren heen en die van de voortgangstoets groei vertonen.

De gemiddelde score van de vaardigheidstoets ligt voor alle jaargroepen veel dichter bij de maximumscore dan bij de minimumscore. Voor de voortgangstoets is dit beeld omgekeerd.

$\mathrm{Bij}$ de stagebeoordelingen is de zeer geringe spreiding van de scores opvallend. Voor de beoordeling van het gemiddelde kennis- en vaardigheidsnivo ligt de gemiddelde score zelfs bijna op het maximum. Er is vrijwel geen spreiding binnen deze oordelen. Deze oordelen worden derhalve weggelaten in de berekeningen. Vrijwel iedere student behaalt een voldoende. De gemiddelde eindbeoordeling over alle stages heen vertoont relatief gezien nog de grootste spreiding. Om zicht te krijgen op de onderlinge verbanden tussen de diverse meetinstrumenten en de sterkte van het verband zijn correlaties berekend binnen en tussen de diverse meetinstrumenten voor de eerste vier studiejaren.

In tabel 2 zijn de correlaties weergegeven tussen de predictorvariabelen (vaardigheidstoets en voortgangstoets) onderling en correlaties van de predictorvariabelen met de criteriumvariabele (stagebeoordelingen). Hoewel vrijwel alle correlaties significant zijn, is de hoogte van de correlationele verbanden over het algemeen laag. Uit de tabel valt ook af 
te lezen dat de correlaties tussen de vaardigheidstoetsen onderling hoger liggen dan die tussen vaardigheidstoetsen en de gemiddelde eindbeoordeling op de stages. Bij de voortgangstoetsen is dit verschil in hoogte van deze correlaties niet zo duidelijk aanwezig. Opvallend is dat zelfs de voortgangstoets van het eerste studiejaar in zekere mate voorspellend is voor de gemiddelde eindbeoordeling op de stages. Voor beide meetinstrumenten geldt dat de toets uit het vierde jaar de meeste samenhang vertoont met de gemiddelde eindbeoordeling op de stages.

Tabel 2: $\quad$ Correlationele verbanden tussen de voortgangstoetsscores (GoedFoutscore) en vaardigheidstoetsscores (Goed score) van de eerste vier studiejaren met de gemiddelde eindbeoordelingen over alle stages (Stagebeoordeling) van de laatste twee studiejaren $(N=122)$.

\begin{tabular}{|c|c|c|c|c|c|}
\hline \multirow[t]{2}{*}{ Instrument } & \multirow{2}{*}{$\begin{array}{l}\text { Stagebeoordeling } \\
\text { Stagebeoordeling }\end{array}$} & \multicolumn{4}{|c|}{ Vaardigheidstoetsen } \\
\hline & & Jaar 4 & Jaar 3 & Jaar 2 & Jaar 1 \\
\hline Stagebeoordeling & - & & & & \\
\hline Vaardigheidstoets 4 & $.40^{* *}$ & - & & & \\
\hline Vaardigheidstoets 3 & .18 & $.38 * *$ & - & & \\
\hline Vaardigheidstoets 2 & $.27^{* *}$ & $.47^{* *}$ & $.66^{* *}$ & - & \\
\hline Vaardigheidstoets 1 & $.27^{* *}$ & $.39 * *$ & $.38^{* *}$ & $.43^{* *}$ & - \\
\hline \multirow[t]{2}{*}{ Instrument } & Stagebeoordeling & \multicolumn{4}{|c|}{ Voortgangstoetsen } \\
\hline & Stagebeoordeling & Jaar 4 & Jaar 3 & Jaar 2 & Jaar 1 \\
\hline Stagebeoordeling & - & & & & \\
\hline Voortgangstoets 4 & $.33 * *$ & - & & & \\
\hline Voortgangstoets 3 & $.37 * *$ & $.49^{* *}$ & - & & \\
\hline Voortgangstoets 2 & $.25 * *$ & $.35^{* *}$ & $.49^{* *}$ & - & \\
\hline Voortgangstoets 1 & $.28^{* *}$ & $.26^{* *}$ & $.31^{* *}$ & $.22^{*}$ & - \\
\hline$*=p \leq 0.05$ & $* *=p \leq 0.01$ & & & & \\
\hline
\end{tabular}

In tabel 3 worden de onderlinge correlaties tussen vaardigheidstoets en voortgangstoets weergegeven. De correlaties tussen vaardigheidstoets- en voortgangstoetsscores zijn laag maar behalve in het eerste jaar in het algemeen wel significant. De hoogte van de correlaties tussen de voortgangs- en vaardigheidstoets met de gemiddelde eindbeoordeling op de stages is dus deels te verklaren vanuit het verband tussen voortgangstoets en vaardigheidstoets onderling. 
Tabel 3: Correlationele verbanden tussen de voortgangstoetsscores en vaardigheidstoetsscores van de eerste vier studiejaren.

\begin{tabular}{|c|c|c|c|c|}
\hline Voortgangstoets & & aardigh & & \\
\hline & Jaar 4 & Jaar 3 & Jaar 2 & Jaar 1 \\
\hline Jaar 4 & $.44^{* * *}$ & $.33 * *$ & $.40^{* *}$ & $.26^{* *}$ \\
\hline Jaar 3 & $.33 * *$ & $.43 * *$ & $.40^{* *}$ & $.30^{* *}$ \\
\hline Jaar 2 & $.27 * *$ & $.40 * *$ & $.33^{* *}$ & $.27^{* *}$ \\
\hline Jaar 1 & .18 & .14 & .10 & .10 \\
\hline$*=p \leq 0.05$ & $* *=\mathrm{P}$ & & & \\
\hline
\end{tabular}

Als de criteriumvariabele stagebeoordelingen sterk samen blijkt te hangen met zowel de vaardigheidstoets als voortgangstoets kan dit het gevolg zijn van de onderlinge gelijke meetinformatie waarover beide predictorvariabelen blijkbaar beschikken. De Lisrel analyse zal hier informatie over verschaffen.

\section{Latente structuuranalyse}

Nagegaan is in hoeverre het gepostuleerde drie-factoren model past bij de gevonden data. Het model veronderstelt dat twee latente onafhankelijke variabelen een derde onafhankelijke variabele voorspellen. Uit de analyse blijkt dat de drie latente variabelen uit het gepostuleerde model (zie figuur 1) passen bij de gevonden empirische data (zie figuur 2). Weliswaar wijst de Chi-kwadraat toets op een significant verschil tussen het gepostuleerde model en de beschikbare data, maar correctie voor het aantal vrijheidsgraden (Chi-kwadraat/df ratio) levert een waarde op van 1.44 per vrijheidsgraad. Gezien het feit dat dit getal beneden de 3.84 ligt ( $p=.05$ bij één vrijheidsgraad) mag dit als een acceptabele waarde worden gezien. 
beide latente variabelen kennis en vaardigheid verklaren samen $57 \%$ van de variantie in het praktisch handelen.

Vervolgens is onderzocht in welke mate vaardigheidstoets- en voortgangstoetsgegevens onafhankelijk van elkaar of anders gezegd "gezuiverd van elkaars invloeden" in staat zijn om het functioneren in de praktijk te voorspellen (structurele model). Hieruit blijkt dat de voortgangstoetsgegevens relatief sterk correleren met het praktisch handelen (0.69). Voor de vaardigheidstoetsgegevens ligt dat een stuk lager (.31). De voortgangstoets is derhalve een aanmerkelijk betere predictor voor het functioneren in de praktijk dan de vaardigheidstoets.

\section{Discussie}

De spreiding van de vaardigheidstoets- en voortgangstoetsscores blijkt relatief groot te zijn. Dit in tegenstelling tot beoordelingen bij de stages. Zeker voor wat betreft de driepuntsschalen van de kennis- en vaardigheidsbeoordeling lijkt het erop dat deze beoordelingsmethode niet tot een gedifferentieerde verdeling in kwalificaties van studenten leidt. Dit is waarschijnlijk te wijten aan twee factoren.

In de eerste plaats is er binnen een groot aantal stages nauwelijks gelegenheid tot systematische kennis- en met name vaardigheidsevaluaties van de student. Tevens bestaat er - ook door de veelvuldige wisselingen van stageplekken per student - niet genoeg informatie over de student, waardoor de beoordelaar geneigd is de student het voordeel van de twijfel te gunnen om vervolgens een voldoende kwalificatie voor dat onderdeel van de stage toe te kennen.

Een andere oorzaak kan zijn dat de driepuntsschaal te grofmazig is om een onderverdeling in studenten aan te brengen. Een aanwijzing hiervoor wordt gevonden in het algemene oordeel, dat tot stand komt op basis van een vijfpuntsschaal. Deze schaal bezit (hoewel bescheiden) een zeker discriminerend vermogen aan de bovenkant van de schaal. Op grond hiervan bleek het niet zinvol de correlaties na te gaan tussen vaardigheidstoetsen met het specifieke onderdeel vaardigheden van de stagebeoordelingen. Hetzelfde geldt voor de voortgangstoetsen met betrekking tot het onderdeel kennis.

In overeenstemming met de gegevens van Carswell e.a. (1987) blijken de correlaties tussen de vaardigheidstoetsen onderling hoog en altijd 
significant. Voor de voortgangstoetsen bereiken de onderlinge correlaties lagere waarden maar ze zijn altijd significant. Correlaties tussen vaardigheidstoetsen en voortgangstoetsen zijn afgezien van het eerste studiejaar ook significant. In tegenstelling echter tot de verwachting is de hoogte van de correlaties tussen beide verschillende meetinstrumenten tenminste gelijk aan die van de voortgangstoetsen onderling. Er blijken significante verbanden te bestaan tussen alle voortgangstoetsen en sommige vaardigheidstoetsen met de gemiddelde eindbeoordelingen op de stages.

Uit de uitgevoerde analyses blijkt dat de vaardigheidstoets geheel tegen de verwachtingen in een slechtere voorspeller is voor het praktisch functioneren later in de studie dan de voortgangstoets. Hiervoor is een aantal verklaringen mogelijk. Een verklaring zou kunnen zijn dat stagebeoordelingen in de praktijk rechtstreeks afhankelijk zijn van het kennisniveau van de student. Dit komt omdat bij alle stages pas een voldoende eindbeoordeling wordt verkregen bij een voldoende gebleken kennisniveau. Dit voldoende kennisniveau moet dan blijken uit een aparte, met voldoende resultaat afgelegde kennistoetsing binnen de stages. Deze kennistoetsing kan de vorm hebben van een schriftelijke toets of van een mondeling examen. Voor de beoordeling van het vaardigheidsaspect binnen de co-assistentschappen zijn dergelijke stringente regels niet bekend. Bovenstaande verklaart zowel de lagere correlaties met de vaardigheidstoets als de hoge correlaties met de voortgangstoets.

Een tweede verklaring is dat de vaardigheidstoets voor wat betreft de inhoud van de eerste vier studiejaren niet lijkt op datgene wat er in de stages wordt geleerd. Hoewel de uitwerking van sommige toetsonderdelen blijkens kritieken van studenten (hoofdstuk 4) soms ver afstaat van de werkelijkheid, kan men in het algemeen stellen dat inhoudsvaliditeit juist een sterk punt is van observatietoetsen en van de vaardigheidstoets in het bijzonder. De aangeboden inhoud van de toets wordt door observatoren relevant voor de basisarts gevonden (hoofdstuk 4). Een derde verklaring kan zijn dat vaardigheden in het onderwijs weliswaar duidelijk afgrensbaar zijn ten opzichte van kennis, maar dat in de empirie het verschil tussen beide domeinen moeilijker is te maken. Met andere woorden "alles is kennis". Dit is echter strijdig met het verschil in sterkte van het verband tussen kennis en vaardigheden enerzijds en praktisch handelen anderzijds. Op grond van het matige verband tussen vaardigheidstoetsresultaten met stageoordelen, zeker in 
vergelijking tot voortgangstoetsresultaten zou nagegaan moeten worden in welke mate het vaardigheidsniveau van de student een rol speelt bij de stagebeoordelingen. Indien het vaardigheidsniveau nauwelijks een rol speelt bij de stagebeoordeling is dit een krachtig pleidooi voor het handhaven van de vaardigheidstoets in de tweede fase. Het sterke verband met de voortgangstoets daarentegen suggereert dat hier tweemaal dezelfde (kennis)meting bij studenten wordt verricht. Wat dit betreft kan men zich afvragen wat een aparte kennismeting in de stage, in welke vorm dan ook, toevoegt aan het oordeel van de voortgangstoets.

Samenvattend kan men op grond van het voorafgaande stellen dat voortgangstoetsen betere voorspellers zijn voor later praktisch functioneren zoals gemeten door de stagebeoordelingen dan vaardigheidstoetsen. Vaardigheidstoetsen lijken een ander domein te toetsen en leveren daarmee aanvullende informatie over de student.

Gezien het feit dat voortgangstoetsen functioneren in de stages beter voorspellen dan vaardigheidstoetsen, zou men ook vraagtekens kunnen stellen bij de inhoudelijke beoordeling van de stages. Worden binnen de stages niet die aspecten gemeten die ook al in de voortgangstoets gemeten worden? Zou de aandacht van de stage-toetsing niet meer gericht moeten worden op inzicht en begrip van medisch denken en handelen? Tevens zou men kunnen overwegen, gezien de verdeling van de scores op de stage beoordelingsformulieren, een "bredere" beoordelingsschaal van de student in het vijfde en zesde studiejaar na te streven. 


\section{EPILOOG}

Voor dit proefschrift is een aantal studies verricht naar aspecten van betrouwbaarheid en validiteit van vaardigheidstoetsen. Welke veranderingen zouden -gezien de resultaten-zinvol zijn, gelet op de huidige stand van zaken met betrekking tot observatietoetsing in het algemeen en die van de vaardigheidstoets in het bijzonder.

In hoofdstuk vier wordt door observatoren gesignaleerd dat er een inhoudelijke onevenwichtigheid bestaat ten aanzien van de hoeveelheid items per inhoudelijke categorie in de vaardigheidstoets. Dit wordt vervolgens bevestigd in hoofdstuk zes. In de vaardigheidstoets zitten veel items die rechtstreeks gerelateerd zijn aan kennis (cognitieve items) en veel items die alleen betrekking hebben op de uitvoering van de vaardigheid (het proces). Daarentegen zijn er weinig items die te maken hebben met interpretatie en uitkomsten van onderzoeksbevindingen. Om te bepalen of deze uitkomst daadwerkelijke actie vereist, zal nagegaan moeten worden wat in de verschillende studiejaren door middel van de vaardigheidstoets gemeten moet worden. Gelet op de doelstellingen van het vaardigheidsonderwijs (hoofdstuk één) en het programma-afhankelijke karakter van het meetinstrument (hoofdstuk twee) lijkt het erop dat de nadruk voor het procesmatig en cognitieve karakter van de toets duidelijk gerelateerd is aan het gegeven onderwijs. Het onderwijs in de eerste studiejaren van de studie geneeskunde is sterk gericht op de uitvoering van de vaardigheid. Interpretaties van onderzoeksbevindingen, laat staan verbanden met ziektebeelden en beleid komen pas vanaf het derde studiejaar aan de orde. De volledige integratie tussen vaardigheden onderling en vaardigheden met kennis vindt waarschijnlijk pas plaats tijdens de co-assistentschappen, dus aan het eind van de studie. De onevenwichtigheid tussen procesmatige en cognitieve items enerzijds en produktmatige items anderzijds lijkt derhalve goed aan te sluiten bij het onderwijs in de eerste twee studiejaren. Vanaf het derde studiejaar lopen 
onderwijs en toetsing langzamerhand uit elkaar op dit punt. Met name bij toetsing in de hoogste jaargroep doet het procesmatige en cognitieve karakter van de vaardigheidstoets afbreuk aan de inhoudsvaliditeit. Dergelijke overwegingen hebben recentelijk al geleid tot forse aanpassingen van de meeste criterialijsten, maar het eindpunt is wat dit betreft nog niet bereikt. In dit verband is het relevant op te merken dat de ervaring leert dat het construeren van observatietoetsen een activiteit is, die sterk onderschat wordt en waar veel tijd en expertise voor nodig is. Aangezien in de meeste situaties de expertise nodig bij het maken van toetsen "al doende" wordt opgebouwd, zijn richtlijnen en achtergronden ten aanzien van toetsconstructie hierbij geen overbodige luxe.

In hoofdstuk vier wordt eveneens gesignaleerd dat een groot aantal observatoren de bruikbaarheid van de criterialijst laag inschat, door de mate van gedetailleerdheid van de beoordelingslijst. Deze gedetailleerdheid wordt gevoeld als een keurslijf en doet volgens sommigen geen recht aan de expertise van de beoordelaar. Maar er kunnen ook andere redenen zijn om te kiezen voor meer globale dan wel gedetailleerde items. Gedetailleerde lijsten hebben het voordeel dat de feedback naar studenten optimaal is. Studenten weten precies wat beheerst moet worden en wat in het tonen van de beheersing fout (of niet) gedaan is. Ook beoordelingslijsten met meer globaal geformuleerde items hebben voordelen. In de eerste plaats wordt tegemoet gekomen aan de bovengenoemde kritiek van observatoren. Observatoren kunnen meer van hun expertise kwijt. Ze vervullen een duidelijkere rol in het beoordelingsproces.

Een ander voordeel van het gebruik van globale criteria is dat het uit het hoofd leren van beoordelingslijsten een minder adequate studiestrategie bij studenten wordt. Globale criteria geven de student minder houvast tijdens de voorbereiding voor de toets, derhalve zullen studenten zich meer gaan richten op het herhalen en daadwerkelijk oefenen van de vaardigheid.

Zoals voor veel aspecten van toetsing, geldt ook hier dat samenstellers van toetsen van tevoren duidelijk moeten maken welk doel met de toetsing wordt beoogd om vervolgens de inhoud en vormgeving van items daaraan aan te passen. In ieder geval blijkt uit hoofdstuk zeven van dit proefschrift, dat het voor de totale toetsbetrouwbaarheid niet uitmaakt of criterialijsten bestaan uit een lijst van gedetailleerde of meer globaal geformuleerde items. In onze situatie lijkt het derhalve 
verstandig voor de hogere jaargroepen (jaargroep vier en zes) met meer globale en voor de andere jaargroepen meer gedetailleerde criterialijsten te gebruiken.

Een ander ervaringsfeit op het gebied van toetsconstructie is dat het voorleggen van het examenmateriaal aan een groep min of meer onafhankelijke deskundigen uit de praktijk, de inhoudelijke en vormtechnische kwaliteit van het examen sterk in positieve zin kan beïnvloeden. Dit laatste behoort één van de axioma's van toetsconstructie te zijn en is uiteraard niet alleen gerelateerd aan observatietoetsing.

Gegevens uit de literatuur (hoofdstuk 2), die bevestigd worden door eigen onderzoek met betrekking tot de vaardigheidstoets, laten zien dat de betrouwbaarheid van observatietoetsen te wensen overlaat. De oorzaak voor deze lage betrouwbaarheid is gelegen in het feit dat binnen een observatietoets het te toetsen domein vaak niet in voldoende mate gedekt wordt. Het is derhalve belangrijk om bij de constructie van dergelijke toetsen te zorgen voor een zo groot mogelijke "domeindekking". Dit kan op twee manieren worden opgelost. Ten eerste kan door een verlenging van toetstijd, zorgen voor een toets met een inhoudelijk meer gevarieerde inhoud. Bij een dergelijke verlenging in toetstijd moet men eerder denken aan uren dan minuten. Gelet op de kosten en de prioriteitsstellingen binnen het huidige wetenschappelijk onderwijs aan de faculteiten Geneeskunde lijkt het onwaarschijnlijk dat oplossingen in deze richting gezocht gaan worden. Wel voorstelbaar is, met betrekking tot de vaardigheidstoets, dat de financiën en formatie nodig voor toetsen uit studiejaar twee en drie ingezet gaan worden voor een verlenging van de toets in het vierde studiejaar.

Een tweede mogelijke aanpak voor het probleem van de domeindekking is dat bij de constructie van het examenmateriaal meer gelet moeten op het meten van de essentie van een vaardigheid of casus. Dit zou tot een besparing leiden in toetstijd, waardoor binnen dezelfde tijdseenheid meer verschillende onderwerpen aan bod kunnen komen. Met deze benadering is tot nu toe nog vrij weinig ervaring opgedaan en is het proberen zeker waard. Desalniettemin zijn hier op voorhand ook al enige bezwaren aan te tekenen. Ten eerste zal het moeilijk zijn om te bepalen wat nu de essentie is van een vaardigheid of casus. Wanneer inhoudsdeskundigen gevraagd worden om essentiële items op criterialijsten aan te geven, blijkt uit ervaring dat er zeer grote verschillen tussen de diverse inhoudsdeskundigen bestaan. 
Een tweede mogelijk bezwaar is dat de tijdsbesparing die optreedt bij het construeren van stations die alleen maar bestaan uit de essentie van de stof bij lange na niet genoeg is om het "tekort" aan betrouwbaarheid op te vangen.

Een derde bezwaar is dat de geschiedenis leert dat alleen het vragen en toetsen van specifieke onderdelen van consulten of vaardigheden als sterk afwijkend van de werkelijkheid wordt beschouwd, zowel door stafleden als studenten en de toets daarmee dus aan validiteit en acceptatie inboet.

Dit betekent niet dat een lage toetsbetrouwbaarheid op grond van bovenstaande dan maar zonder meer geaccepteerd moet worden. Uitgaande van het feit dat het voor de individuele student vervelender is onterecht te zakken dan onterecht te slagen, zou men de betrouwbaarheid van de beslissing "gezakt" bijvoorbeeld kunnen vergroten door de studenten die met een kleine marge gezakt zijn een verlengde toets aan te bieden, waardoor ze alsnog de kans krijgen te slagen.

Uitdrukkelijk dient hierbij eveneens gewezen te worden op het feit dat, afhankelijk van de setting waarin de toets plaatsvindt, sommige observatietoetsen beschouwd kunnen worden vanuit het perspectief van "mastery learning". Dit betekent dat onderwijsgevenden van mening zijn dat studenten minimaal het aangeboden vaardigheidspakket op voldoende niveau moeten beheersen. Dit kan geëist worden aangezien er sprake is van een relatief klein, goed omschreven gebied aan basisvaardigheden wat gekend en "gekund" moet worden. Vanuit die optiek speelt de betrouwbaarheid een "ondergeschikte rol".

De verschillende typen observatietoetsen hanteren verschillende zak/slaaggrenzen. Deze variabiliteit geeft al aan dat inhoudsdeskundigen kennelijk op goede gronden tot verschillende conclusies kunnen komen ten aanzien van de cesuur. Voor een groot deel zijn deze verschillen terug te voeren op verschillen tussen de domein- of normgeoriënteerde benadering.

De combinatie van een relatieve norm met een absolute boven- en ondergrens (hoofdstuk acht) lijkt te voldoen als normeringsmethode voor de vaardigheidstoets. Het lijkt redelijk om een relatieve norm te hanteren omdat er met name bij een vaardigheidstoets zich altijd gebeurtenissen kunnen voordoen die niet onder controle te houden zijn en die een negatieve invloed kunnen hebben op de prestaties van de student. Hierbij kan men bijvoorbeeld denken aan verschillen in gedrag tussen simulatiepatiënten en observatoren. Anderzijds is een absolute norm op 
grond van de inhoud van de toets goed verdedigbaar en worden de nadelen die gepaard gaan met een strikte toepassing van een relatieve norm bij de vaardigheidstoets vermeden.

Dit proefschrift maakt duidelijk dat verschillen in cesuur tot aanzienlijke verschillen in zak/slaagpercentages kunnen leiden. Gelet op de consequenties die dit voor individuele studenten kan hebben dient het vaststellen van een cesuur ook zeer zorgvuldig te gebeuren. Deze zorgvuldigheid dient te blijken uit kennis met betrekking tot het verwachte niveau van examens in relatie tot het gegeven onderwijs, inzicht in de mogelijke foutenbronnen die de studentscore kunnen beïnvloeden en het kunnen inschatten van de relevantie van de inhoud. Extra informatie omtrent het vaststellen van de cesuur kan verkregen worden door mensen uit de beroepsgroep zelf een dergelijke toets te laten doorlopen.

Zoals ook al aangegeven bij de conclusies van hoofdstuk negen dient de relatie tussen de vaardigheidstoets, voortgangstoets en stagebeoordelingen nadere aandacht. Het is onduidelijk of de geringe voorspellende waarde van de vaardigheidstoets voor de praktische stages te "wijten" is aan onvolkomenheden van de vaardigheidstoets of aan de wijze waarop beoordelingen in de stage tot stand komen. De geringe predictie van de vaardigheidstoets, hoewel alternatieve verklaringen daarvoor in hoofdstuk negen te vinden zijn, is bevreemdend. Juist in de afgelopen jaren is er veel energie gestoken in de vaardigheidstoets van het zesde studiejaar, in die zin dat de inhoud en de setting zoveel mogelijk de praktijksituatie zou benaderen. Over het algemeen is deze verandering zeer gewaardeerd door stafleden en studenten. Dit maakt de geringe samenhang tussen vaardigheidstoets en stagebeoordelingen vergeleken bij voortgangstoetsresultaten des te opmerkelijker. Een kritische beschouwing van de inhoudelijke criteria waarop studenten beoordeeld worden zowel in de stages alsook bij de vaardigheidstoets, kan hierbij uitkomst bieden. Eveneens is het wenselijk dat onderzoek met betrekking tot de predictieve validiteit van observatietoetsen wordt voortgezet, gelet op het geringe aantal gegevens waarover men nu beschikt.

Het is wellicht denkbaar dat de vaardigheidstoets in het zesde studiejaar en een deel van de stagebeoordelingen in de toekomst samen kunnen opgaan in een afsluitende medische competentietoets. Hierbij weegt het nadeel van een eenmalig afsluitend examen mogelijk op tegen de grote 
voordelen die de infrastructuur van de vaardigheidstoets biedt. Hierbij kan gedacht worden aan inhoudelijke (toetsbeoordelingscommissie) en psychometrische bewaking van de toets en het creëren van vergelijkbare situaties voor elke student. 


\section{SAMENVATTING}

Verspreid over de gehele wereld hebben observatietoetsen zich in de loop der jaren een belangrijke plaats weten te verwerven binnen een groot aantal medische opleidingen. Binnen het medisch onderwijs bestond de indruk dat alleen kennismeting niet voldoende informatie verschaft over de kwaliteit van de basisarts.

Vaardigheidstoetsen doen uitspraken over het vaardigheidsniveau van toekomstige artsen en dragen daarmee bij aan de bestaande meetinformatie omtrent de kwaliteit van artsen die de opleiding afronden. Bij de introductie van deze toetsen waren er vrijwel geen psychometrische gegevens beschikbaar over de eigenschappen van dergelijke toetsen. De afgelopen jaren is er echter een grote stroom onderzoeksgegevens beschikbaar gekomen over de vaardigheidstoets. Ook dit proefschrift draagt hieraan bij door het beschrijven van een aantal studies rondom de betrouwbaarheid en validiteit van de vaardigheidstoets (hoofdstuk zes tot en met negen). Deze empirische hoofdstukken worden voorafgegaan door een aantal hoofdstukken die bedoeld zijn om de gestelde onderzoeksvragen te plaatsen.

Hoofdstuk één geeft een nadere specificatie van het begrip vaardigheid. Hierbij wordt een onderscheid gemaakt tussen psychomotorische vaardigheden enerzijds en sociale vaardigheden anderzijds. Vervolgens wordt ingegaan op de argumenten die ten grondslag liggen aan de implementatie van deze vaardigheden in een apart "vaardigheidscurriculum" binnen de studie geneeskunde. Met name wordt aandacht besteed aan het leren van psychomotorische en sociale vaardigheden en de onderlinge integratie ervan binnen de specifieke context van het probleemgestuurd onderwijs. 
Hoofdstuk twee geeft een beschrijving van de wijze waarop vaardigheden gemeten worden. Hierbij wordt grofweg een onderscheid gemaakt tussen de Objective Structured Clinical Examination (OSCE) en de Standardized Patient-based Test (SP-based test). Het hoofdstuk wordt afgesloten met literatuurgegevens omtrent betrouwbaarheid en validiteit van vaardigheidstoetsen. Geconcludeerd wordt dat de totale toetsbetrouwbaarheid met name afhankelijk is van het aantal verschillende inhoudelijke aspecten dat gemeten wordt. Dit is een punt van zorg bij observatietoetsen. De inhoudsvaliditeit van dergelijke toetsen wordt daarentegen vaak als een sterk punt beschouwd.

Hoofdstuk drie gaat in op de plaats van de vaardigheidstoets binnen het geheel van evaluatie-activiteiten in het probleemgestuurd onderwijs aan de Faculteit der Geneeskunde. Gedetailleerd wordt aangegeven hoe beoordelingen tot stand komen zowel met betrekking tot de vaardigheidstoets als ook met betrekking tot de verschillende andere evaluatie instrumenten aan de faculteit. Ingegaan wordt eveneens op de kwaliteitszorg van de afgenomen toetsen.

Vervolgens wordt uitgebreid ingegaan op de vorm en inhoud van de vaardigheidstoets. Gesteld wordt dat de vaardigheidstoets zoals die in Maastricht wordt afgenomen, zowel van de OSCE alsook van de SPbased test, zoals beschreven in hoofdstuk twee, delen heeft overgenomen. De vorm van de vaardigheidstoets in de eerste fase van de studie lijkt veel op de OSCE, terwijl de vaardigheidstoetsen in de tweede fase van de studie meer overeenkomen met de SP-based test.

Hoofdstuk vier gaat in op de ervaringen opgedaan met de vaardigheidstoets. Deze ervaringen zijn weergegeven op enquêtes die systematisch gedurende de afgelopen elf jaar zijn afgenomen bij studenten en observatoren. Over het algemeen laten de uitslagen van de enquêtes een redelijk stabiel beeld zien. De vaardigheidstoets wordt door studenten en observatoren als een relevante toets gezien voor de basisarts. Kritiek heeft men soms op het fragmentarische en gedetailleerde karakter van de inhoudelijke elementen waaruit de toets bestaat. Ook hebben observatoren de indruk dat het proces van de vaardigheid, door de grote hoeveelheid items die hierop betrekking hebben, meer wordt gewaardeerd in de toetsuitslag dan de uitkomst van de handeling. Het werken met gedetailleerde criterialijsten wordt over het algemeen minder gewaardeerd dan globale criterialijsten. Studenten lijken feedback van observatoren tijdens de toets erg op prijs te stellen. 
Hoofdstuk vijf geeft de vraagstellingen voor onderzoek weer, op basis van de informatie verstrekt in de eerste vier hoofdstukken.

Hoofdstuk zes bevat een inhoudelijke analyse van twee vaardigheidstoetsen. Hierbij zijn items uit de toets inhoudelijk geclassificeerd. Uit de classificatie blijkt dat er een scheve verdeling bestaat met betrekking tot de hoeveelheid items behorend bij bepaalde inhoudelijke categorieën van de onderzochte toetsen. Conform de waarnemingen van observatoren in hoofdstuk vier zijn items met een cognitief en procesmatig karakter aanzienlijk zwaarder in de toets vertegenwoordigd dan items met een produktmatig karakter. Studenten blijken items met een procesmatig en cognitief karakter ook beter te beheersen dan items met een produktmatig karakter. Gelet op de doelen van het vaardigheidsonderwijs in de verschillende jaren (hoofdstuk een) lijkt er een inhoudelijke discrepantie te bestaan tussen de inhoud van het onderwijs en de inhoud van de vaardigheidstoets in de hogere studiejaren. Inhoudelijke veranderingen in de vaardigheidstoets die meer aansluiten op de onderwijsdoelen zouden kunnen leiden tot grotere aantallen gezakte studenten en een lagere betrouwbaarheid voor toetsen.

Hoofdstuk zeven gaat in op het verschil in betrouwbaarheid tussen gedetailleerde en meer globale criterialijsten. In deze studie worden beide soorten lijsten door dezelfde observator gebruikt bij het beoordelen van vaardigheden bij studenten. Een controle studie wijst uit dat het invullen van dergelijke lijsten na elkaar door dezelfde observator nauwelijks invloed heeft op de beoordeling. Uit de vergelijking van de scores van studenten blijkt dat beoordelingen op basis van een gedetailleerde schaal tot meer extreme scores leidt dan beoordelingen op basis van een globale schaal. Ten aanzien van de betrouwbaarheid van beide soorten criterialijsten kan worden geconcludeerd dat er geen duidelijk verschil bestaat tussen globale en gedetailleerde criterialijsten op het niveau van de totale toetsbetrouwbaarheid. Ook ten aanzien van de inhoud van de verzamelde informatie komen beide beoordelingsvormen overeen. Gelet op de voorkeur van observatoren voor minder gedetailleerde criterialijsten (hoofdstuk 4) heeft deze bevinding belangrijke praktische consequenties.

Hoofdstuk acht heeft betrekking op de wijze waarop de normering voor de vaardigheidstoets kan worden vastgesteld. In aansluiting op hoofdstuk drie waar de huidige regelingen met betrekking tot de normering van de 
vaardigheidstoets uitvoerig worden weergegeven, geeft hoofdstuk acht een aantal alternatieven voor het bepalen van de cesuur. Uit de resultaten blijkt dat de verschillende benaderingswijzen om tot een bepaalde cesuur te komen, enorme grote verschillen in zak/slaagpercentages teweeg kunnen brengen. De cesuur die bij de vaardigheidstoets wordt toegepast blijkt niet tot extreme zak/slaagpercentages te leiden. Geconcludeerd wordt dat het komen tot een bepaalde normstelling gebaseerd moet zijn op een zorgvuldige afweging van doelen die men beoogt te bereiken met toetsing.

Hoofdstuk negen heeft betrekking op de predictieve validiteit van de vaardigheidstoets voor het succesvol doorlopen van de klinische stages. Als referentiepunt wordt hierbij de toets voor het meten van algemene medische kennis, de voortgangstoets (hoofdstuk drie) gebruikt. Geheel tegen de verwachtingen in blijkt de vaardigheidstoets een slechtere voorspeller voor praktisch functioneren later in de studie dan de voortgangstoets. Dit kan liggen aan de inhoud van de vaardigheidstoets (hoofdstuk 6) maar ook aan de wijze waarop stagebeoordelingen tot stand komen. Dat de voortgangstoets een dergelijk grote predictieve waarde heeft voor het succesvol doorlopen van de stages eveneens opvallend. Geconcludeerd wordt dat nader onderzoek op dit terrein wenselijk is om de gegeven verklaringen voor deze onverwachte bevindingen te toetsen. 


\section{SUMMARY}

Testing skills by standardized observation is a relatively new area in medical education. Starting in the late seventies, this method of testing is slowly becoming an integrated part of the assessment program in many medical schools. Hence, educational research with respect to the validity and reliability of this assessment instrument is relevant. Substantial work has already been carried out in this field of research. Nevertheless many questions remain unanswered.

This thesis discusses some questions related to the implementation of an observational test, called the Skills Test, in the Maastricht problem-based curriculum. Empirical research is preceded by four chapters concerning the role, position and experience of patient-based testing in the Maastricht medical school.

Chapter 1 describes the various definitions of a skill given in the literature and how the term skill is defined in the Maastricht educational program. The chapter also discusses how skills are taught in a curriculum. A description is given of the content and organization of the skillstraining program in the curriculum.

Chapter 2 provides an overview of observational testing in medical education. The Objective Structured Clinical Examination (OSCE) and the Standardized Patient-Based test are described, and differences between the two formats are discussed. Also problems of reliability and validity are explained.

Chapter 3 focuses on the assessment system implemented by the Maastricht medical school and the role of the Skills Test in the whole system. Compared to other curricula the Skills Test plays a more important role in decisions concerning graduation of students. In the 
second part of this chapter, a more detailed description is given about the content and format of the Skills Test. Differences and similarities between the Skills Test on the one hand and the OSCE and PatientBased tests on the other are analyzed. These differences, however small, are mainly related to differences in aims of the tests. The similarities focus mainly on the psychometric characteristics of the different test formats.

Chapter 4 reviews the experiences with Skills Testing during the last ten years based on results of numerous questionnaires. Both students and staff consider the Skills Test as relevant and important. However, there is also criticism. Students experience the test as very stressful. It seems that because "being observed" is stressful in itself. Sometimes, the behaviour of some observers is also a very stress-stimulating factor. The criticism of the faculty-observers is more related to the validity of the test. Especially the very detailed checklists are criticized. Also the relevance of items is discussed. Many observers have the feeling that students learn the tricks but do not understand the essence of practising skills.

A final experience is that skillstesting in the way it is implemented, is a dominant factor steering student-learning.

Chapter 5 summarizes the research questions derived from the information and experiences with observational testing described in the preceding chapters. The research questions deal with the content of the Skills Test, the specificity of items in the checklist, the different standard-setting methods en the predictive validity of the Skills Test.

Chapter 6 presents a study on the content of the Skills Test. This chapter investigates the criticism of observers that items concerning procedures of a skill and concerning knowledge are far more represented in the test than items concerning outcome of skills. If this is true, it makes the test less representative for future practice, creating a problem of validity.

To investigate this problem, the items of the Skills Test were divided in different content categories. The categories were related to items concerning knowledge of skills, items representing motoric performance, items concerning the process of a skill and items related to the outcome of skills. The criticism of observers appears to be true. The Skills Test is dominated by items which refer to knowledge and process. It also 
appeared that items related to outcome show the lowest scores by students. Pass/fail decisions only based on outcome items would lead to more students failing compared to other categories. The different categories show moderate to high correlations. The reliability of the different categories is also assessed. Tests consisting of only process items are more reliable than tests consisting of outcome items.

Chapter 7 focuses on the value of global rating scales compared to the more detailed checklists. More specifically, this chapter describes the effects on scores and ranking of students using global rating scales and checklists. Also the results of students based on both formats are compared with the (global) impressions of the staff members and with the results of a knowledge test (progress test).

It appears that checklist scoring leads to higher scores for students including a greater standard deviation than scores based on global ratings. Related to pass/fail decisions, global ratings are milder for students than detailed ratings.

With respect to the reliability, the interrater reliability of checklist ratings is better. But despite this, and more importantly, the total-test reliability of both formats is more or less the same. Rater-errors at the station level apparently average out adequately across stations. The correlation between the different formats is high. Correlations with the progress test were low and the same for both formats.

Chapter 8 reviews some standard-setting methods. The advantages and disadvantages of the different methods are discussed. A number of standard-setting methods are applied on a sample Skills Test. The different methods lead to substantial differences in pass/fail decisions. Standard-setting methods related to the content of the test (domainreferenced) tend to be more severe than norm-referenced methods. It could be argued that the severity of the domain-referenced method is probably the result of the bias that judges only judge the content they are familiar with, and therefore tend to overestimate the competency of students.

In terms of severity, the standard-setting method which is used in the regular assessment program in Maastricht lies somewhere in between the norm- and domain- referenced methods. 
Chapter 9 discusses the predictive validity of the results of the Skills Test and the knowledge test (progress test) in the first four preclinical years in relation to clinical ratings of students in years five and six. Contrary to expectations, the knowledge test has a better predictive validity than the Skills Test. A possible explanation is the dominance of knowledge testing as part of the clinical rating. An alternative explanation is that the content of the Skills Test does not cover clinical practice. It is argued that the first explanation is more likely. 


\section{LITERATUUR}

Angoff, W.H. (1971) Scales, Norms and Equivalent Scores. In: Thomdike, R.I.. (Ed.). Educational Measurement. Washington: American Council on Education.

Bartstra, H.L.J. (1987) Vaardigheidsonderwijs in de praktijk. In: Dochy, F.J. \& Van Luijk, S.J.(red.). Handboek Vaardigheidsonderwijs. Lisse, Swets \& Zeitlinger.

Berk. R.A. (1986) A consumers guide to setting performance standards on crilerionreferenced tests. Revien of Educational Reseurch, 56, 137-172.

Boumans. M.T.A. \& Van Ooy. A. (1990) Het onderzoek van de bovenste extremiteiten. RU Limburg. Maastricht: Bunge.

Brennan, R.L. (1983) Elements of Generalizability Theory. Iowa: American College Testing Program.

Bryan, W.L. \& Harter, N. (1897) Studies in the physiology and psychology of the telegraphic language. Psychological Review, 4, 27-53.

Carswell, F., Primavesi, R. \& Ward. P. (1987) Qualifying exams for medical students: are both major finals and continuous assessment necessary? Medical Teacher, 9. 83-90.

Cohen, J. (1960) A coefficient of agreement for nominal scales. Educational and Psychological Measurement, 10, 37-46.

Cohen, R., Rothman, A., Ross, J., MacInnes, A., Domavitch, E., Jamieson, C., Jewitt, M., Keystone, J., Kulesha, D., McCleary, P., Ouchterlony, D., Poldre, P., Robb, K., Rossi, M., Sarin, M., Schwartz, M., Sherman, R. \& Shier, M. (1987) Comprehensive assessment of clinical performance. In: Hart, I. \& Harden, R. (Eds.). Further Developments in Assessing Clinical Competence. Montreal: Heal Publications.

Cohen, R., Rothman, A.I., Poldre, P. \& Ross, J. (1990) Validity and Generalizability of Global Ratings in an Objective Structured Clinical Examination. University of Toronto (unpublished). 
Colliver, J., Verhulst, S., Williams, R. \& Norcini, J. (1989) Reliability of performance on standardized patient cases: A comparison of consistency measures based on generalizability theory. Teaching and Learning in Medicine, 1, 31-37.

Colliver, J.A., Steward, D.E., Markwell, S.J. \& Marcy, M.L. (1991) Effect of Repeated Simulations by Standardized Patients on Intercase Reliability. Teaching and Learning in Medicine, 1, 15-19.

Conn, H.L. \& Cody, R.P. (1989) Results of the second clinical skills assessment examination of the ECFMG. Academic Medicine, 64, 448-453.

Cratty, B.J. (1964) Movement Behaviour and Motor Learning. Philadelphia: Lea \& Febinger.

De Block, A. \& Heene, J. (1986) Inleiding tot de Algemene Didactiek. Antwerpen: Uitgeverij Standaard.

De Groot, A.D. (1964) De kernitemmethode voor de bepaling van de caesuur voldoende/onvoldoende. Pedagogische Studiën, 11, 425-440.

Driessen, S.D. (1987) Studenten over vaardigheidsonderwijs: vaardigheden leren, hoe gaat dat? In: Dochy, F.J. \& Van Luijk, S.J. (red.). Handboek Vaardigheidsonderwijs. Lisse: Swets \& Zeitlinger.

Ebel, R. (1965) Measuring Educational Achievement. Englewood Cliffs: Prentice-Hall, Inc.

El Mouzan, M.I. (1992) Secondary school and admission test grades as predictors of performance of medical students. Medical Education, 26, 123-127.

Espoir, N.E.J.C. I’, Van Luijk, S.J. \& Vleuten, C.P.M. van der (1987) The Skillstest: An adequate Predictor for Clinical Performance? Paper presented at the International Conference on Assessment for Medical Education. Beer-Sheva, Israel.

Famuyiwa, O. O., Zachariah. M.P. \& Mechukwu, S.T.C (1991) The objective clinical structured clinical examination in undergraduate psychiatry. Medical Education, 25, 45-50.

Flexner, A. (1910) Medical Education in the United States and Canada. A Report to the Camegie Foundation for the Advancement of Training. Bulletin Number 4. Boston: Updike, The Merrymount Press.

Flexner, A. (1912) Medical Education in Europe. A Report to the Carnegie Foundation for the Advancement of Teaching. Bulletin Number 6. Boston: Updike, The Merrymount Press.

Franssen, M.J., Van Dalen, J. \& Scherpbier, A.J.J.A. (1992) Studenten op verkenning in het bejaardentehuis. In: Vleuten, C.P.M. van der, Scherpbier, A.J.J.A., Pollemans, M.C. (red.). Gezond Onderwijs. Houten: Bohn, Stafleu Van Loghum B.V. 
Frijns, P.H.A.M. (1993) Over Structurering van Beoordelingsmethoden voor Open Vragen. Academisch proefschrift Rijksuniversiteit Limburg.

Gonella, J.S., Hojat, M., Erdmann, J.B. \& Veloski, J.J. (1993) A Case of Mistaken Identity: Signal and Noise in Connecting Performance Assessments before and after Graduation from Medical School. Academic Medicine, 68, s9-s16

GPEP Report (1984) Physicians for the Twenty-First Century. Report of the Panel on the General Profession Education of the Physician and College Preparation for Medicine. Washington: Association of American Medical Colleges (AAMC).

Grava-Gubins, I., Khan, S. \& Rainsberry, P. (1987) Factor analysis of simulated office oral examinations in family medicine. In: Hart, I.R. \& Harden, R.M. (Eds.). Further Developments in Assessing Clinical Competence. Montreal: Heal Publications.

Hall, F.R. \& Bailey, M.A. (1992) Correlating students' undergraduate science GPA's, their MCAT scores, and the academic caliber of their undergraduate colleges with their firstyear academic performances across five classes at Dartmouth Medical School. Academic Medicine, 67, 121-123.

Harden, R.M. \& Gleeson, F.A. (1979) ASME Medical Education Booklet No 8. Assessment of clinical competence using an objective structured clinincal examination (OSCE). Medical Education.

Hess, J.W. (1969) A comparison of methods for evaluating medical student skills in relating to patients. Journal of Medical Education, 44, 934-938.

Hofstee, W.K.B. (1981) Een gebufferde oplossing voor het bepalen van de grens tussen voldoende en onvoldoende. Universiteit en Hogeschool, 28, 1, 21-29.

Hofstee, W.K.B. (1985) Liever Klinisch? Grenzen aan het objectiviteitsheginsel bij beoordeling en selectie. Nederlands Tijdschrifi voor de Psychologie, 40, 459-473.

Jöreskog, K.G. \& Sörbom, D. (1981) Analysis of Linear Structural Relationships by maximum likelihood and least squares methods. Version V. International Education Services.

Kane, M. (1982) The validity of licensure examinations. American Psychologist, 37, 1118.

Klass, D., Campbell, Hassard, T., Kopelow, M. \& Schnabl, G. (1990) Influence of level of training on performance in a standardized test of clinical abilities. In: Bender, W., Hiemstra, R.J., Scherpbier, A.J.J.A. \& Zwierstra, R.P. (eds.). Teaching and Assessing Clinical Competence. Groningen: Boekwerk publications.

Knapp, B.N. (1964) Skill in Sport. London: Routledge \& Kegan Paul. 
Kraan, H.F. \& Crijnen, A.A.M. (1987) The Maastricht History Taking and Advice Checklist. Academisch proefschrift Rijksuniversiteit Limburg.

Leeuw, P.W. de, Dubois, V. \& Webers, J. (1992) Rapport van de commissie "Visitatie Skillslab". Inteme publicatie RL.

Littlefield, J.H. \& Troendle, G.R. (1987) Effects of rating task instructions on consistency and accuracy of expert raters. Paper presented at the Annual Meeting of the American Educational Research Association. Washington, D.C.

Livingston, S.A. \& Zieky M.J. (1982) Passing scores. Princetown: Educational Testing Service.

Lodewick, L. (1978) Het Lichamelijk Onderzoek, een Atlas voor de Algemene Praktijk. Utrecht: Bohn, Scheltema \& Holkema.

Lunefeld, E., Weinreb, B., Lavi, Y., Amiel, G.E. \& Friedman, M. (1991) Assessment of emergency medicine: a comparison of an experimental objective structured clinical examination with a practical examination. Medical Education, 25, 38-44

Mann, K.V., MacDonald, A.C. \& Norcini, J.J. (1990) Reliability of objective structured clinical examinations: four years of experience in a surgical clerkship. Teaching and Learning in Medicine, 4, 219-224.

Markert, R.J. (1993) The relationship of academic measures in medical school to performance after graduation. Academic Medicine, 68, s31-s34.

Metz, J.C.M. (1984) Medische Competentie. Een onderzoek naar de betrouwbaarheid en validiteit van het Gestructureerd Klinisch Examen. Academisch proefschrift Katholieke Universiteit Nijmegen.

Mitchell, K.J. (1990) Traditional predictors of performance in medical school. Academic Medicine, 65, 149-158.

Moust, J.H.C., Bouhuijs, P.A.J. \& Schmidt, H.G. (1989) Probleemgestuurd leren. Hoger Onderwijs Reeks. Groningen: Wolters-Noordhoff.

Newble, D.I. \& Jaeger, K. (1983) The effect of assessments and examinations on the learning of medical students. Medical Education, 17, 165-171.

Newble, D.I. \& Entwistle, N.J. (1986) Learning styles and approaches, implications for medical education. Medical Education, 20, 162-175.

Newble, D.I. \& Swanson, D. (1988) Psychometric characteristics of the objective structured clinical examination. Medical Education, 22, 325-334.

Norman, G.R., Smith, E.K.M., Powles, A.C.P., Rooney, P.J., Henry, N.L. \& Dodd, P.E. (1987) Factors underlying performance on written tests of knowledge. Medical Education, 21, 297-304. 
Norman, G.R., Van der Vleuten, C.P.M. \& Graaf, E. de (1991) Pitfalls in the pursuit of objectivity: Issues of validity, efficienty and acceptability. Medical Education, 25, 119 126.

Petrusa, E., Blackwell, T., Parcel, S. \& Saydjari, C. (1986) Psychometric properties of the objective clinical exam as an instrument for final evaluation. In: Hart, I., Harden, R. \& Walton J. (Eds.). Newer Developments in Assessing Clinical Competence. Montreal: Heal Publications.

Petrusa, E., Blackwell, T. \& Ainsworth, M. (1987 A) Performance of internal medicine house officers on a short station OSCE. In: Hart, I., Harden, R. \& Walton J. (Eds.). Further Developments in Assessing Clinical Competence. Montreal: Heal Publications.

Petrusa, E., Blakwell, T., Rogers, L., Saydjari, C., Parcel, S. \& Guckian, J. (1987 B) An objective measure of clinical performance. American Journal of Medicine, 83, 34-42.

Petrusa, E. (1988) Collaborative Project to Improve the Evaluation of Clinical Competence. Final Report to the National Fund for Medical Education.

Perkowski-Rogers, L., Solomon, D., Speer, A. \& Ainsworth, M. (1992) Clinical relevance of station length and checklist scores on the assessment of clinical skills. In: Harden, R.M., Hart, I.R. \& Mulholland, H. (Eds.). Approaches to the Assessment of Clinical Competence. Norwich: Page Brothers.

Phaff, C. (1987) Het gebruik van simulatiepatiënten in het onderwijs. In: Handboek Vaardigheidsonderwijs. Dochy, F.R.C. \& Van Luijk, S.J. (red.). Lisse: Swets \& Zeitlinger.

Phaff, C \& Spronken, Th. M. Th. E. (1987) G.O.M.'s als docenten bij het onderwijs in het gynaecologisch onderzoek. In: Dochy, F.R.C. \& Van Luijk, S.J. (red.). Handboek Vaardigheidsonderwijs. Lisse: Swets \& Zeitlinger.

Robb, M.D. (1972) The dynamics of motor-skill acquisition. New Jersey: Prentice Hall Inc.

Rosenfeld, L.M., Hojat, M., Veloski, J.J., Blacklow, R.S. \& Goepp. C. (1992) Delays in completing medical school: predictors and outcomes. Teaching and Learning in Medicine, 3. $162-167$.

Rutten, G.E.H.M. \& Thomas, S. (red.). (1993) NHG-Siandaarden voor de huisarts. Utrecht: Bunge.

Schmidt, H.G. \& Moust, J.H.C. (1981) Studiebeleving van Maastrichtse medische studenten. Medisch Contact, 49, 1515-1518.

Schouten, J.A.M. (1982) Anamnese en advies. Alphen a/d Rijn: Stafleu Uitgeverij.

Shatzer, J.H., Wardrob, J.L., Bible, K.C., Williams, R.G., Rhee, K., Carlson, M. \& Witkovsky. M.T. (1992) Station length requirements for SP exams: their influence on generalizability estimates. In: Hart, I.R. \& Harden, R.M. \& Des Marchais (Eds.). Current Developments in Assessing Clinical Competence. Montreal: Can-Heal Publications. 
Singleton, W.T. (1978) The analysis of practical skills. Lancaster: MTP Press Limited.

Singleton, W.T. (1983) Social Skills. In: Singleton, W.T. (Ed.). The Study of Real Skills (Vol 4). Lancaster: MTP Press Limited.

Stillman, P., Rutula, P., Nicholson, G., Sabers, D. \& Stillman, A. (1982) Measurement of clinical competence of residents using patient instructors. Proceedings of the 21st Annual Conference on Research in Medical Education, 111-116.

Stillman, P., Swanson, D., Smee, S., Stillman, A., Ebert, T., Emmel, V., Caslowitz, J., Greene, H., Hamolsky, M., Hatem, C., Levenson, D., Levin, R., Levinson, G., Ley, B., Morgan, J., Parrino, T., Robinson, S. \& Willms, J. (1986) Assessing clinical skills of residents with standardized patients. Annals of Internal Medicine, 105, 762-771.

Stillman P. \& Swanson, D. (1987) Ensuring the clinical competence of medical school graduates through standardized patients. Archives of Internal Medicine, 147, 1049-1052.

Stillman, P.\& Swanson, D. (1989) Use of standardized patients for assessment of historytaking, physical examination, and communication skills. Final Report on the ABIM Standardized Patient Project. The New England Consortium of Internal Medicine Residency Training Programs.

Stillman, P., Regan, M., Swanson, D., Case, S., McCahan, J., Feinblatt, J. Smith, S., Willms, J., Nelson, D. (1990) An assessment of the clinical skills of fourth-year students at four New England Medical Schools. Academic Medicine, 65, 320-326.

Streiner, D.L. (1985) Global rating scales. In: Neufield, V.R. \& Norman, G.R. (Eds.). Assessing Clinical Competence. New York: Springer Publishing Company.

Swanson, D. (1987) A measurement framework for performance-based tests. In: Hart, I.\& Harden, R. (Eds). Further Developments in Assessing Clinical Competence. Montreal: Heal Publications.

Swanson, D., Haynes, R., Killian, C., Regan, M., Stillman, P. \& Case, S. (1992) Validity of undergraduate college GPA's and MCAT scores for predicting performance on a Clinical skills examination. In: Harden, R.M., Hart, Mulholland (Eds.), Approaches to the Assessment of Clinical Cornpetence. Norwich: Page Brothers.

Tamblyn, R.M., Klass, D.J., Schnabl, G.K. \& Kopelow, M.L. (1991) The accuracy of standardized patient presentation. Medical Education, 25, 100-109.

Tan, L.H.C. (1989) Tekorten in de opleiding van huisartsen, ziektebeelden en medischrechnische vaardigheden. Academisch proefschrift Universiteit van Amsterdam.

Templeton, B., Best, A., Samph, T. \& Case, S. (1978) Short-term outcomes achieved in interviewing medical students. Internal Report, National Board of Medical Examiners. 
Tumer, B.J., Hojat, M. \& Gonella, J.S. (1987) Using ratings of resident competence to evaluate NBME examination passing standards. Journal of Medical Education, 62, 572 581.

Van der Vleuten, C.P.M. \& Van Luijk, S.J. (1987) Decomposition of OSCE's: Some methodological considerations and empirical findings. In: Hart, I.R. \& Harden, R.M., (Eds.). Further Developments in Assessing Clinical Competence. Montreal: Heal Publications.

Van der Vleuten, C.P.M., Van Luijk, S.J, \& Swanson, D. (1988-A) Reliability (generalizability) of the Maastricht Skills Test. Proceedings of the Twenty-seventh Annual Conference of Research in Medical Education, 228-233.

Van der Vleuten, C.P.M., Van Luijk, S.J. (1988-B) Betrouwbaarheid van observatietoetsen voor practische vaardigheden in het medisch onderwijs. Tijdschrift voor Onderwijsresearch, 13, 213-226.

Van der Vleuten, C.P.M., Van Luijk, S.J., Ballegooijen, A.M.J. \& Swanson, D.B. (1989A) Training and experience of medical examiners. Medical Education, 22, 290-296.

Van der Vleuten, C.P.M., Van Luijk, S.J. \& Beckers, H.J.M. (1989-B) A written test as an alternative to performance testing. Medical Education, 23, 97-107.

Van der Vleuten, C.P.M. (1989-C) Naar een rationeel systeem voor toetsing van studieprestaties in probleemgestuurd medisch onderwijs. Academisch proefschrift Rijksuniversiteit Limburg.

Van der Vleuten, C.P.M. \& Swanson, D.B. (1990) Assessment of Clinical Skills with Standardized Patients; State of the Art. Teaching and Learning in Medicine, 2, 58-76.

Van der Vleuten, C.P.M. \& Verwijnen, G.M. (1990) A system for student assessment. In: Problem-based learning: Perspectives from the Maastricht experience. Van der Vleuten, C.P.M. \& Wijnen, W. (Eds.). Amsterdam: Thesis.

Van der Vleuten, C.P.M., Norman, G.R. \& Graaf, E. de (1991) Pitfalls in the pursuit of objectivity: Issues of reliability. Medical Education, 25, 110-118.

Van Dorp, C. (1977) Luisteren naar patiënten, een analyse van het medisch interview. Lochem: de Tijdstroom.

Van Luijk, S.J., Van der Vleuten, C.P.M. \& Van Schelven, R.M. (1990) Observer and student opinions about skills tests. In: Bender, W., Hiemstra, R.J., Scherpbier, A.J.J.A., Zwierstra, R.P. (Eds.). Teaching and Assessing Clinical Competence. Groningen: BoekWerk Publications: 497-502.

Van Luijk, S.J., Louw, A. de, Visser, K., Scherpbier, A.J.J.A. \& Van der Vleuten, C.P.M. (1993) De ondankbare taak als observator bij de vaardigheidstoets. Paper gepresenteerd op het Gezond Onderwijs Congres, Veldhoven. 
Van Thiel, J. (1992) Assessment of Medical Interviewing Skills: Generalizability of Scores Using Successive Maas versions. In: Harden, R.M., Hart, I., Mulholland, H. (Eds.). Approaches to the Assessment of Clinical Competence. Norwich, Page Brothers.

Visser, K., Louw, A. de, Van Luijk, S.J. \& Scherpbier, A.J.J.A. (1993) Beïnvloedt het gedrag van de observator de prestatie van studenten? Paper presentatie Gezond Onderwijs Congres, Veldhoven.

Vu, N.V., Marcy, M.M., Colliver, J.A., Verhulst, S.J., Travis, T.A. \& Barrows, H.S. (1992) Standardized (simulated) patient's accuracy in recording clinical performance check-list items. Medical Education, 26, 99-104.

Vu, N.V., Distlehorst, L.H. Verhulst, S.J. \& Colliver, J.A. (1993) Clinical performancebased test sensitivity and specificity in predicting first-year residency performance. Academic Medicine, 68, s41-s45.

Warrick, S.S. \& Crumrine, R.S. (1986) Predictors of succes in an anesthesiology residency. Journal of Medical Education, 61, 591-595.

Williams, R.G. \& Barrows, H.S. (1987) Performance based assessment of Clinical Competence using clinical encounter multiple stations. In: Hart, I.R. \& Harden, R.M. (Eds.). Further Developments in Assessing Clinical Competence. Montreal: Can-Heal Publications.

Welford, A.T. (1958) Ageing and Human Skill. London: Oxford University Press.

Wijnen, W.H.F.W. (1971) Onder of boven de maat. Academisch proefschrift Rijksuniversiteit Groningen. 
BIJLAGE 1 
Overzicht van Skillslab/PMO activiteiten in het curriculum 1991/1992

Blok 1.1. Inleiding in de studie geneeskunde

Fysisch diagnostische vaardigheden

Introductie fysisch diagnostisch onderzoek.

Vertrouwelijkheid, oefenen op elkaar, beroepsgeheim.

Instrumenteel technische vaardigheden

Injecteren 1: Injectievormen en materialen, leren vullen van een injectiespuit. Leren aseptisch werken.

Verbandleer 1: Zwachteltechnieken arm, knie en hiel, middenhand en pols.

\section{Laboratorium vaardigheden}

Introductie laboratoriumvaardigheden, hemoglobine bepaling volgens Spencer.

Tweede Stroom Onderwijs (TSO)

Sociale vaardigheden: Kennismaken met onderdelen TSO-programma.

Basisvaardigheid: Luisteren.

Simulatiepatiëntcontact: Simulatiepatiënt in de TSO-groep.

Blok 1.2. Opname en afhraak

Fysisch diagnostische vaardigheden

Abdomen I en II: Buikonderzoek met behulp van basistechnieken: inspectie, auscultatie, percussic en palpatie.

Instrumenteel technische vaardigheden

Injecteren II: Verrichten van injecties, zoals geleerd in blok 1.1, op elkaar.

Verbandleer II: Zwachteltechnieken middenvoet/enkel, vinger en hele hand. Aanleggen mitella.

Laboratoriumvaardigheden

Blved/urineonder/wek bij diabetes, Micro-afname, Hb, Ht, M.C.H.C.

Tweede Stroom Onderwijs

Sociale vaardigheden: Observeren en non-verbaal gedrag.

Simulatiepatiëntcontact: Simulatiepatiënt in TSO-groep.

Attitude-ontwikkeling: Nabespreking snijzaalpracticum.

Blok 13. Interactie en regulatie

Fysisch diagnostische vaardigheden

Neurologie/Bew.App.:Introductietraining neurologie en bewegingsapparaat; algemene principes onderzoek.

Neurologie: $\quad$ onderzoek perifere zenuwstelsel (motoriek/sensibiliteit/reflexen). 


\section{Instrumenteel technische vaardigheden}

Injecteren III: Intraveneuze injectie en venapunctie, oefenen op elkaar.

Verbandleer III: Veneuze en capillaire bloedingen behandelen

d.m.y. wonddekverbanden.

\section{Laboratoriumvaardigheden}

Inzetten en beoordelen BSE.

Leren omgaan met de microscoop.

\section{Tweede Stroom Onderwijs}

Sociale vaardigheden: Omgaan met gevoelens/inhouds- en betrekkingsniveau.

Simulatiepatiëntcontact: Simulatiepatiëntcontact met nabespreking.

Attitude-ontwikkeling: Bespreekbaar maken van moeilijke gespreksonderwerpen.

\section{Blok 1.4. Aanval en afweer}

\section{Fysisch diagnostische vaardigheden}

Het onderzoek van de voet en de enkel.

Het onderzoek van de tractus respiratorius d.m.v. inspectie, palpatie, percussie en auscultatie.

\section{Instrumenteel technische vaardigheden}

Verbandleer IV: Eerste hulp bij bloedstelping: slagaderlijke bloeding en spataderlijke bloeding.

\section{Laboratoriumvaardigheden}

Maken en kleuren van een bloeduitstrijk met het benoemen van erythrocyten, thrombocyten en leucocyten.

Maken en kleuren van een bacteriologisch preparaat.

\section{Tweede Stroom Onderwijs}

Sociale vaardigheden: Vraagverheldering I, kennismaken met het vraagverhelderingsgesprek, integratie van tot nu toe geleerde sociale vaardigheden.

Simulatiepatiëntcontact: Tweemaal een simulatiepatiëntcontact en de nabespreking hiervan. Attitude-ontwikkeling: Dwangsituaties: normen en waarden t.a.v. bepaalde hulpvragen.

\section{Blok 1.5. Ontregeling geregeld}

\section{Fysisch diagnostische vaardigheden}

Het onderzoek van de tractus circulatorius d.m.v. inspectie, palpatie, percussie en auscultatie.

Bloeddrukmeting.

\section{Instrumenteel technische vaardigheden}

Verbandleer V: Hulp bij letsels van weke delen: Aanleggen van drukverbanden enkel, knie en pols.

Injectie IV: Intraveneus injecteren, venaject methode en oefenen op elkaar. 


\section{Laboratoriumonderzoek}

Urineonderzoek.

\section{Tweede Stroom Onderwijs}

Sociale vaardigheden: Vraagverhelderingsgesprek en integratie van alle tot dusver verworven sociale vaardigheden.

Simulatiepatiëntcontact: Tweemaal een simulatiepatiëntcontact en de nabesprekingen hiervan.

Attitude-ontwikkeling: Voor- en nabespreking van ambulance en EHBO-stages.

\section{Blok 1.6. Grenzen van de zorg}

\section{Fysisch diagnostische vaardigheden}

Onderzoek van de perifere arteriële circulatie en bloeddrukmeting.

Ongevalssimulatie: Aan de hand van casuïstiek uitgebeeld door simulatiepatiënten van de Lotuskring Zuid-Limburg worden alle tot nu toe geleerde instrumenteel technische vaardigheden in gesimuleerde ongevalssituaties toegepast en nabesproken met een vaardigheidsdocent.

\section{Instrumenteel technische vaardigheden}

Resuscitatie I: Theorie, beslismomenten, uitvoering afzonderlijke vaardigheden, volgorde van handelingen.

\section{Laboratoriumvaardigheden}

Bloedonderzoek: Interpretatie van bloedbepalingen, veneuze afname m.b.v. venaject methode.

\section{Tweede Stroom Onderwijs}

Sociale vaardigheden: Het leren geven en ontvangen van feedback. Evaluatie van het doorlopen TSO-programma.

Attitude-ontwikkeling: Omgaan met schaarste in de gezondheidszorg, bespreking van stage in de kliniek.

\section{Blok 2.1. Waarnemen, bewustzijn en emoties}

\section{Fysisch diagnostische vaardigheden}

Oogonderzoek: Visusbepaling en subjectieve refractie; Opsporen gezichtsvelduitval; opsporen abnormale ongstand.

Ooronderzoek: Inspectie oor; gehoorgang d.m.v. otoscoop; gehooronderzock d.m.v. fluisterspraak, stemvorkproef en audiometrie.

Neurologie: Het onderzoek van de hersenzenuwen.

\section{Tweede Stroom Onderwijs}

Sociale vaardigheden: Kennismaking met de TSO-groep, bespreken van de leerdoelen van jaar 2.

Simulatiepatiëntcontact: Een simulatiepatiëntcontact met nabespreking.

Attitude-ontwikkeling; Videopresentatie over toepassingen psychochirurgie $<->$ houding t.o.v. emoties en omgaan met afwijkende emoties. 


\section{Blok 2.2. Locomotion}

Fysisch diagnostische vaardigheden

Techniek en systematiek van het onderzoek van het bewegingsapparaat:

schoudergordel

elleboog

pols en hand

wervelkolom.

Instrumenteel technische vaardigheden

Verbandleer VI: Het aanleggen van de preventieve enkelbandage en een algemene herhaling van alle verbanden.

\section{Tweede Stroom Onderwijs}

Sociale vaardigheden: De structuur van het consult met nadruk op de vraagverheldering. Simulatiepatiëntcontact: Tweemaal een simulatiepatiëntcontact en tweemaal nabespreking hiervan samen met de TSO-groep.

\section{Blok 2.4. Met vallen en opstaan}

\section{Fysisch diagnostische vaardigheden}

Oogonderzoek: Het onderzoek van het voorste oogsegment en het onderzoek van de oogfundus d.m.v. fundoscopie.

\section{Laboratoriumvaardigheden}

De sensitiviteit en specificiteit van de verschillende laboratoriumonderzoken van urine.

\section{Tweede Stroom Onderwijs}

Sociale vaardigheden: Bespreken en oefenen van de vaardigheid "uitleggen".

Simulatiepatiëntcontact: Een simulatiepatiëntcontact en de nabespreking hiervan in de TSO-groep.

Data presentatie: Samen met de vakgroep O \& O worden een drietal trainingen besteed aan de vaardigheden die nodig zijn bij het presenteren van onderzoek aan een panel van deskundigen.

\section{Blok 2.5. Groei en differentiatie}

\section{Fysisch diagnostische vaardigheden}

Algemeen gynaecologisch onderzoek: inspectie/palpatie uitwendige genitalia, het speculumonderzoek, het maken van een uitstrijkje en het bimanueel onderzoek. Onderzoek vroeg in de zwangerschap. Techniek en systematiek onderzoek tijdens beginnende, fysiologische zwangerschap.

\section{Instrumenteel technische vaardigheden}

Resuscitatie II: Toepassen van resuscitatie vaardigheden met een of twee helpers.

Resusciteren bij kinderen.

Integratie van het thorax en abdomenonderzoek tot één onderzoek. 


\section{Laboratoriumvaardigheden}

Urineonderzoek: De werking en achtergronden van zwangerschapstesten.

\section{Tweede Stroom Onderwijs}

Sociale vaardigheden: Voorlichtings- en adviesgesprek I.

Simulatiepatiëntcontact: Tweemaal een simulatie en tweemaal de nabespreking hiervan in de TSO-groep.

\section{Blok 2.6 Geboren en getogen}

\section{Fysisch diagnostische vaardigheden}

Onderzoek van de zwangere in de tweede helft van de zwangerschap en tijdens de ontsluitingsfase van de baring. Begeleiding van de uitdrijvingsfase (baring in Aav) en het nageboortetijdperk. Het onderzoek van de pasgeborene.

Schoolkindcontact: anamnese en lichamelijk onderzoek bij een schoolkind.

\section{Laboratoriumvaardigheden}

Het maken en beoordelen van natieve preparaten fluor en urine.

\section{Tweede Stroom Onderwijs}

Sociale vaardigheden: Voorlichtings- en adviesgesprek II.

Simulatiepatiëntcontact: Tweemaal een simulatie en tweemaal de nabespreking hiervan in de TSO-groep.

\section{Blok 2.7. De jaren die tellen}

\section{Fysisch diagnostische vaardigheden}
Abdomen:
Onderzoek van de liezen, externe genitalia en het rectale toucher.
KNO:
Thorax:
Het onderzoek van de mond-/keelholte en de neus.
daarbij behorende specifieke testen.
Gynaecol./Obst.: Het onderzoek van de mammae.
Bew. app.: Het onderzoek van de heup.

\section{Instrumenteel technische vaardigheden}

Indicatiestelling voor en verrichten van een blaascatheterisatie.

\section{Tweede Stroom Onderwijs}

Sociale vaardigheden: Het voeren van een slecht nieuws gesprek.

Simulatiepatiëntcontact: Tweemaal een simulatie en tweemaal de nabespreking hiervan in de TSO-groep.

\section{Blok 3.1. Kort van adem en pijn op de borst}

\section{Fysisch diagnostische vaardigheden}

Thorax: Onderzoek van de hoestende patiënt

Onderzoek van de patiënt met thoracale pijn

Onderzoek van de kortademige patiënt. 


\section{Instrumenteel technische vaardigheden}

Resuscitatie III: Herhaling resuscitatietechnieken. Orotracheale intubatie, beademing via een mayo-tube m.b.v. een beademingsballon.

\section{Laboratoriumvaardigheden}

Laboratoriumdiagnostiek bij luchtwegaandoeningen m.b.v. sputumonderzoek.

\section{Tweede Stroom Onderwijs}

Sociale vaardigheden: Kennismakingsbijeenkomst, bespreking structuur van het consult en vaststellen leerdoelen jaar 3.

Simulatiepatiëntcontact: Tweemaal een simulatie en de nabespreking hiervan in de TSOgroep.

Bejaardencontact: Inleiding in de bejaardenproblematiek. De studenten worden in het derde studiejaar elk blok in de gelegenheid gesteld een contact met de bejaarde te hebben in het bejaardentehuis. Deze contacten vinden plaats in het kader van TSO en worden ook begeleid door de TSO-begeleider. De thematiek van het bejaardencontact grijpt terug op de aan dat blok voorafgaande blokthematiek.

\section{Blok 3.2. Inabilities}

\section{Fysisch diagnostische vaardigheden}

Neurologie: Het onderzoek van de patiënt met uitvalsverschijnselen.

Het onderzoek van de patiënt met tintelingen in arm/been.

KNO:

Oog:

Het onderzoek van de patiënt met gehoorstoomissen en anamnese.

Het onderzoek van de patiënt met visusstoornissen en anamnese.

\section{Tweede Stroom Onderwijs}

Sociale vaardigheden: Het oefenen en bespreken van verslaglegging van de anamnese en het lichamelijk onderzoek.

Simulatiepatiëntcontact: Tweemaal een simulatie en de nabespreking hiervan in de TSOgroep.

Bejaardencontact: Het onderwerp van dit contact is hart en/of longproblematiek.

\section{Blok 3.3. Stemmings- en gedragsproblemen}

\section{Fysisch diagnostische vaardigheden}

Neurologie: Onderzoek van de hogere cerebrale functies a.h.v. casuïstiek.

Onderzoek van de patiënt met dementiële verschijnselen.

Patiëntencontact: De studenten voeren een geheel consult met een echte patiënt (anamnese en lichamelijk onderzoek). Het geheel wordt nabesproken met een Skillslabdocent.

\section{Tweede Stroom Onderwijs}

Sociale vaardigheden: Probleemverheldering bij psychosociale problematiek.

Simulatiepatiëntcontact: Tweemaal een simulatie en tweemaal de nabespreking hiervan in de TSO-groep.

Bejaardencontact: Het onderwerp van dit hejaardencontact betreft neurologische problematiek. 
Blok 3.4. Het binnenste van buiten

\section{Fysisch diagnostische vaardigheden}

Bew.app.: Het onderzoek van de patiënt met houdingsafwijkingen.

Thorax: De diagnostiek en behandeling van het ulcus cruris.

\section{Laboratoriumvaardigheden}

De laboratoriumdiagnostiek bij huid- en haaraandoeningen.

\section{Tweede Stroom Onderwijs}

Sociale vaardigheden: Het onderwerp van deze training is het tweesporenbeleid deel I. Simulatiepatiëntcontact: Spreekuursimulatie, elke student ziet in een uur 3 patiënten. De videobanden van deze contacten worden over twee nabespreekbijeenkomsten verdeeld. Bejaardencontact: Het onderwerp van dit bejaardencontact betreft dementiële beelden.

\section{Blok 3.5. Pijn}

\section{Fysisch diagnostische vaardigheden}

Bew.app.: Het onderzoek van de patiënt met schouderklachten. Het onderzoek van de patiënt met chronische rugklachten. Het onderzoek van de patiënt met knieklachten.

\section{Tweede Stroom Onderwijs}

Sociale vaardigheden: Het onderwerp van deze training is het tweesporenbeleid deel II. Simulatiepatiëntcontact: Tweemaal een simulatie en tweemaal de nabespreking hiervan in de TSO-groep.

Bejaardencontact: Het onderwerp van dit bejaardencontact betreft locomotore problemen.

\section{Blok 4.1. Problemen met voortplanting en sexualiteit}

\section{Fysisch diagnostische vaardigheden}

Gynaecol./Obst.: Het onderzoek bij afwijkend zwangerschapsverloop.

Het onderzoek bij afwijkende liggingen.

De baring bij een stuitligging (Bracht) en spildraaistoomissen

Het onderzoek van de pasgeborene (pathologie).

\section{Laboratoriunnvaardigheden}

Het onderzoek van fluor en ecoulement.

\section{Tweede Stroom Onderwijs}

Sociale vaardigheden: Het afnemen van de sexuele anamnese.

Simulatiepatièntcontact: Tweemaal een simulatie en tweemaal de nabespreking hiervan in de TSO-groep. 


\section{Blok 4.2. Abdominal complaints}

\section{Fysisch diagnostische vaardigheden}

Abdomen: Aan de hand van papieren casuïstiek wordt het gehele buikonderzoek geoefend. Ook wordt de techniek en systematiek van het onderzoek van de liezen, externe genitaliën en het rectale toucher, besproken a.h.v. casuïstiek.

\section{Instrumenteel technische vaardigheden}

Blaascatheterisatie en maagsondering.

\section{Laboratoriumvaardigheden}

Het algemene faecesonderzoek; Urineonderzoek: sediment.

\section{Tweede Stroom Onderwijs}

Sociale vaardigheden: Het onderwerp van deze training is dwangsituaties I.

Simulatiepatiëntcontact: Tweemaal een simulatie en tweemaal de nabespreking hiervan in de TSO-groep.

\section{Blok 4.3. Koorts, infecties en ontstekingen}

\section{Fysisch diagnostische vaardigheden}

Bew .app:

Het onderzoek van de knie aan de hand van reactieve arthritis casüstiek.

KNO:

Behandeling neusbloeding (tamponade), reinigen uitwendige gehoorgang en verwijderen corpus alienum.

\section{Laboratoriumvaardigheden}

Laboratoriumonderzoek bij een urineweginfectie.

Het beoordelen van het leucocytenbeeld.

Laboratoriumvaardigheden met betrekking tot parasitologie.

\section{Tweede Stroom Onderwijs}

Sociale vaardigheden: Het onderwerp van deze training is dwangsituaties II.

Simulatiepatiëntcontact: Spreekuursimulatie, in een uur tijd zien de studenten 4 simulatiepatiënten. De nabespreking hiervan is verdeeld over 2 TSO-bijeenkomsten. Schoolkindcontact:Een tweetal studenten onderzoeken een schoolkind (dat een rol ingestudeerd heeft) m.n. op KNO-gebied, en long- en buikonderzoek.

\section{Blok 4.5. Bloedverlies}

Fysisch diagnostische vaardigheden

Gyn.Jobst: $\quad$ Het onderzoek bij bloedverlies per vaginam.

\section{Instrumenteel technische vaardigheden}

Wondsluiting I : Wondtoilet

Wondsluiting II: Wondhechting 


\section{Laboratoriumvaardigheden}

Hemocytometrie.

Het urine-onderzoek bij (verdenking op) hematurie.

Het faeces-onderzoek op occult bloed.

\section{Tweede Stroom Onderwijs}

Sociale vaardigheden: De vaardigheden die nodig zijn bij het presenteren van een patiënt aan een panel deskundigen zullen worden besproken en geoefend.

Simulatiepatiëntcontact: Gedurende blok 4.5 en 4.6 is er per TSO-groep 5 maal een simulatiepatiënt waarin een duo studenten een simulatiepatiënt zien. Deze contacten worden niet nabesproken maar de studenten presenteren de patiënt aan hun TSO-groep.

\section{Blok 4.6. Moeheid en vermagering}

\section{Fysisch diagnostische vaardigheden}

Oog: $\quad$ Het oogonderzoek en de anamnese bij een patiënt met diabetes mellitus.

Neurologie: Het onderzoek bij een patiënt met een neuropathie.

\section{Instrumenteel technische vaardigheden}

Het inbrengen van een infuus.

\section{Laboratoriumvaardigheden}

Laboratoriumdiagnostiek bij diabetes mellitus.

Casuïstiek van - en microscopisch onderzoek bij anaemie.

\section{Tweede Stroom Onderwijs}

Zie blok 4.5.

Patiëntencontact: Hart-, long- en neurologisch onderzoek bij een echte patiënt. Dit contact wordt nabesproken met een vaardigheidsdocent.

\section{Blok 4.7. Acute nood}

\section{Fysisch diagnostische vaardigheden}

Bewegingsapparaat: Het heuponderzoek aan de hand van casuïstiek.

Ongevalssimulatie: In circuitvorm worden ongevallen gesimuleerd waarbij de studenten in groepjes van vier adequate hulp moeten verlenen. Dit geheel wordt begeleid door een vaardigheidsdocent.

\section{Instrumenteel technische vaardigheden}

Oefenen van alle tot nu toe geleerde verbanden.

\section{Tweede Stroom Onderwijs}

Sociale vaardigheden: Het onderwerp van deze training is crisisinterventie.

Simulatiepatiëntcontact: Tweemaal cen simulatie en tweemaal de nabespreking hiervan in de TSO-groep. 
BIJLAGE 2 


\section{Fysisch diagnostische vaardigheden}

\section{Thorax}

Te beheersen vaardigheden:

* inspectie

* palpatie

* percussie

* auscultatie

* inspectie van het hart

* palpatie van het hart

* auscultatie van het hart

* onderzoek van de perifere arteriële circulatie

* onderzoek van de carotiden

* meting van de bloeddruk

* in de handleiding Thorax m.b.t. de tractus circulatorius nu ook de tekstfragmenten "voor gevorderden"

* een aantal abnormale bevindingen dient juist benoemd te worden onderzoek van de mammae

\section{Abdomen}

Te beheersen vaardigheden:

* voorwaarden buikonderzoek

* inspectie (inclusief liezen)

* auscultatie beoordeling peristaltiek vaatgeruisen wrijfgeruisen klotsen scratch-auscultatie methode zwelling in liesstreek

* percussie

percussie algemeen percussie lever percussie milt karakter percussietoon

* palpatie palpatie algemeen palpatie oppervlakkig (actief/passief spierverzet) palpatie diep:

a.aigemeen

b.druk-en/of loslaatpijn

c.lever/galblaas

d.milt

e.nieren (slagpijn, ballotement, echappement)

licolun 


\section{g.buikarterieën}

h.abnormale weerstanden

* palpatie lieskanaal

* rectaal toucher

* inspectie van anus en regio perianalis

* inspectie en palpatie penis, scrotum en scrotum inhoud

* diafanoscopie

* speciale onderzoektechnieken en enkele fenomenen:

klotsen

ascites/undulatiefenomeen

psoasfenomeen

hyperaestesiefenomeen

differentiatie pulserende zwelling in epigastrio, punt van "Mac Burney"

\section{Gynaecologie algemeen}

Te beheersen vaardigheden:

techniek en systematiek van:

* inspectie en palpatie van uitwendige genitalia

* het speculum onderzoek (inspectie inwendige genitalia)

* het maken van een cervix-uitstrijk (pap-smear)

* het bimanueel onderzoek (weke delen)

* het recto-vaginale toucher

* het rectale toucher

\section{Obstetrie algemeen}

Te beheersen vaardigheden:

techniek en systematiek van:

* inspectie en palpatie uitwendige genitalia

* het speculum onderzoek (inspectie inwendige genitalia)

* het maken van een cervix-uitstrijk (pap-smear)

* het bimanueel onderzoek (weke delen)

* het recto-vaginale toucher

* het rectale toucher

* het uitwendig zwangerenonderzoek (uterus)

* handgrepen van Leopold

* onderzoek harttonen van kind in utero

\section{Obstetrie: De baring}

Te beheersen vaardigheden:

de techniek en systematiek van:

* het stellen van de diagnose "in partu"

* het obstetrisch toucher (benoemen P.O.V.I.A.S.)

* het relateren van het uitwendig zwangerenonderzoek aan het obstetrisch toucher 
* het stellen van de uitdrijvingsindicatie

* het geven van de juiste persinstructie/perstechniek

* het begeleiden van de baring in A.a.v.

* het uitzuigen, afnavelen en overhandigen van de pasgeborene

* het beoordelen van de klinische toestand van de pasgeborene direct post-partum (APGAR-score)

* het leiden van het nageboorte tijdperk

\section{Fluor genitalis}

Te beheersen vaardigheden:

techniek en systematiek van:

* de afname van fluor genitalis

* het maken van $\mathrm{KOH}$ en $\mathrm{NaCL}$ preparaat

* het enten van fluor op diverse media

\section{Gynaecologische pathologie}

Te beheersen vaardigheden:

het verrichten van onderzoek bij:

* vaginaal bloedverlies

* gynaecologische pijnklachten

* fluor genitalis

\section{Pathologie zwangerschap}

Te beheersen vaardigheden:

* het vaststellen of de nidatie intra-uterien heeft plaatsgevonden

* het vaststellen of het ongeboren kind normaal ontwikkeld is en in een goede conditie verkeert

* het middels uitwendig zwangerenonderzoek opsporen van afwijkingen bij het ongeboren kind, welke behandeling behoeven of een medische indicatie tot klinische partus kunnen bepalen

\section{Pathologie baring}

Te beheersen vaardigheden:

* het detecteren en benoemen van afwijkende liggingen:

hoofdliggingen:

middenstand

voorhoofdsligging

aangezichtsligging

achterhoofdsligging met verscherpt mechanisme

hoge rechtsstand

diepe dwarsstand 
wandbeenligging

stuitliggingen:

volkomen

onvolkomen

dwarsligging

* het begeleiden van de baring in stuitligging volgens Bracht

* het detecteren en verhelpen van uitdrijvingsstoomissen:

omstrengeling navelstreng

spildraaistoornissen

schouderdystocie

\section{Keel/Neus/Oorheelkunde}

Te beheersen vaardigheden:

* inspectie en palpatie van de oorschelp

* palpatie en percussie mastö̈d

* gebruik elektrische voorhoofdslamp/reflector

* otoscopie

* het afnemen van een audiogram

* stemvorkproeven van Weber, Rinne en Schwabach

* fluisterspraak en conversatiespraak

* gebruik elektrische voorhoofdslamp/reflector

* inspectie mond/keelholte

* palpatie mond/keelholte

* inspectie uitwendige larynx

* palpatie uitwendige larynx

* inspectic uitwendige neus

* palpatie uitwendige neus

* beoordelen van neusdoorgankelijkheid

* rhinoscopia anterior en posterior

* palpatie van de sinus frontales

* percussie van de sinus frontales

* palpatie van de sinus maxillares

* percussie van de sinus maxillares

* diafanoscopie sinus frontales

* palpatie lymfeklieren hoofd-halsgebied

* diafanoscopie sinus maxillares

* stelpen van een neusbloeding, voorste neustamponade

* verwijderen corpus alienum uit neus of gehoorgang

* oor uitspuiten/verwijderen cerumen

* inbrengen van een tampon in de gehoorgang

* toedienen van neus/oor druppels

* methode van Politzer

* proef van Romberg

* oogvolgbewegingsonderzoek

* positioneringsduizeligheidsonderzoek

* Pathologie $\mathrm{v} / \mathrm{h} \mathrm{KNO}$-gebied + bijbehorende anamnese 


\section{Ogen}

Te beheersen vaardigheden:

* bepaling gezichtsveld

* bepaling gezichtsscherpte

* scheelzien (onderzoek oogstand)

* onderzoek achterste oogsegment (fundoscopie)

* onderzoek voorste oogsegment

\section{Neurologie}

Te beheersen vaardigheden:

* onderzoek motoriek

* onderzoek sensibiliteit

* onderzoek reflexen

* onderzoek coördinatie

* wortelprikkelingsproeven LWK

* wortelprikkelingsproeven CWK

* onderzoek hersenzenuwen

\section{Kind}

Te beheersen vaardigheden:

* Het kunnen afnemen van een adequate, probleem-georiënteerde hetero-anamnese.

* Uit de anamnestisch verkregen gegevens de gepaste fysisch-diagnostische onderzoeken kunnen afleiden en correct kunnen uitvoeren.

* Uit de gegevens van anamnese en fysisch diagnostisch onderzoek aanvullende onderzoekingen kunnen afleiden.

\section{Bewegingsapparaat}

Te beheersen vaardigheden:

* het onderzoek van de rug

* het onderzoek van de schouder

* het onderzoek van de elleboog

* het onderzoek van pols en hand

* het onderzoek van de heup

* het onderzoek van de knie

* het onderzoek van de voet en enkel 


\section{Therapeutische vaardigheden}

Te beheersen vaardigheden:

* injectievloeistof opzuigen uit een flacon

* injectievloeistof opzuigen uit een ampul

* intramusculaire injectie

* subcutane injectie

* intraveneuze injectie

* intracutane injectie

* venapunctie met vacuumsysteem

* venapunctie met spuit en naald

* het inbrengen van een infuus (naaldsysteem + canulesysteem)

* het verwisselen van infuuskolven

* instellen druppelsnelheid

* het verwijderen van een infuus

* het inbrengen van een sonde in de maag

* het verwijderen van vloeistoffen uit de maag d.m.v.maaghevelen

* het inbrengen van een catheter in de blaas (bij de man en de vrouw)

* toepassing van incontinentie-opvangmiddelen en stomazorg

* inspectie en reinigen van een wond

* infiltratie anesthesie van een wond

* wond sluiten met hechtdraad

* chirurgische knoop maken m.b.v. naaldvoerder

* chirurgische knoop (handknopen)

* draadhechtingen verwijderen

* het vaststellen van het bewustzijnsniveau

* controle van de circulatie

* controle van de ademhaling

* uitwendige hartmassage bij een volwassene

* mond-op-mond beademing bij een volwassene

* resuscitatie van een volwassene met en zonder gebruik van hulpmiddelen

* ballonbeademing volwassenen

* de resuscitatie bij een zuigeling en een kind

* orothracheale intubatie

* het inbrengen van de mayo tube

* het verwijderen van vreemde voorwerpen uit de bovenste luchtwegen bij een volwassene

* spoed coniotomie

* stabiele zijligging

* verzorging van ulcus cruris en aanlegging van pressure gradiéntverband

* wonddekverband aan arm, been, knie, elleboog. hiel, vinger, hand, voet. middenvoet, enkel, middenhand en pols

* snelverband, zwaluwstaartje

* slagaderlijke bloeding stelpen door arteria brachialis arteria sublavia of arteria femoralis dicht te drukken

* eerste hulp bloedstelping bij spataderlijke bloeding

* wonddrukverband

* drukverband om pols, knie en enkel 
* aanleggen oogverband

* preventieve enkelbandage

* mitella, verhoogde mitella en brede das

* toedieningsvormen van medicijnen (oog, oor, neus, mond, rectum, vagina)

\section{Laboratorium vaardigheden}

\section{Algemeen}

Te beheersen vaardigheden:

Gebruik, centreren, instellen Köhlerse verlichting

\section{Bloed}

Te beheersen vaardigheden:

* maken en kleuren van een bloeduitstrijk

* benoemen van leucocyten, erythrocyten en trombocyten

* hemoglobine bepalen volgens Spencer èn van Kampen en Zijlstra

* hematocriet bepalen

* inzetten en aflezen van een macrobezinking volgens Westergren

* systematische beoordeling van het normale bloeduitstrijkje

* glucosebepaling in capillair bloed, ijken van de bloedglucosestrips

Urine

Te beheersen vaardigheden:

* macroscopisch onderzoek

* in de urine bepalen van reducerende stoffen, bloed, leucocyten, ph, glucose, ketonen, galkleurstoffen, nitriet en HCG

* eiwit volgens Bang en soortelijke dichtheidbepaling

* het maken van een natief urinesediment-preparaat

* beoordelen oriënterend urine onderzoek

* beoordelen van een urinesediment

* het inzetten en beoordelen van een dipslide

\section{Gramkleuring}

Te beheersen vaardigheden:

* maken, kleuren en benoemen van een gram preparaat

\section{Fluoronderzoek en ecoulement onderzoek}

Te beheersen vaardigheden:

* maken en beoordelen natief en $\mathrm{KOH}$-preparaat 


\section{Methyleenblauwkleuring}

Te beheersen vaardigheden:

* maken en benoemen van een methyleenblauw gekleurd preparaat

\section{Faecesonderzoek}

Te beheersen vaardigheden:

* macroscopisch onderzoek

* bepalen van bloed in de faeces

* onderzoek van wormen en wormeieren

\section{Sputumonderzoek}

Te beheersen vaardigheden:

* beoordelen macroscopisch aspect sputum

* beoordeling grampreparaat van het sputum

\section{Sociale vaardigheden}

Te beheersen vaardigheden:

* vraagverhelderingsgesprek voeren (diagnostisch gesprek fase 1)

* anamnesegesprek voeren (diagnostisch gesprek fase 2)

* voorlichtingsgesprek voeren

* adviesgesprek voeren

* integratie van deze gespreksfasen tot een geheel consult

Basale vaardigheden van het arts-patiënt consult:

* luisteren

* samenvatten

* observeren

* gevoelens reflecteren

* informatie inwinnen:

open vragen stellen doorvragen binnen het referentiekader van de patiënt parafraseren concretiseren gesloten vragen stellen

* informatie overdragen:

uitleggen confronteren 
omgaan met weerstand van de patiênt

* besluitvorming en besluiten nemen t.a.v. beleid

* structurering van het consult:

fase overgangen markeren

tijd bewaken

* integratie van de verschillende gespreksfasen

" omgaan met "probleempatiënten" 


\section{BIJLAGE 3}




\section{Voorbeeld criterialijst uit het eerste studiejaar}

Criterialijst:

Domein:

Categorie:

Naam Station:

Prod. datum:

Gemaakt door:

Bestemd voor:

Benodigd

- Patiënten:

- Modellen:

- Instrumenten:

- Meubilair:

- Video-app.:

- Diversen:

- Materialen:
02102

Therapeutische vaardigheden

Wondverzorging en verbandleer

Het stelpen van een slagaderlijke bloeding

December 1986

M. Kunz en W. van Zutphen

Herkansingstoets le jaars 1990/1991

steriel gaas, $5 \times 5 \mathrm{~cm}$ en $10 \times 10 \mathrm{~cm}$, witte watten, vette watten, cambric zwachtel $6 \mathrm{~cm}$, cambric zwachtel $10 \mathrm{~cm}$.

Omschrijving situatie:

De proefpersoon heeft de rechterarm ontbloot en horloge en sieraden verwijderd.

Met een viltstift wordt een wond van $+2 \mathrm{~cm}$ lang en $1 \mathrm{~cm}$ breed getekend op de pols ter hoogte van de art. radialis. De proefpersoon hoeft geen pijn te simuleren.

Instructies voor de student(e):

- Bij de proefpersoon is bij de pols een wond getekend met een slagaderlijke bloeding.

- Verleen alle hulp, die U in zo'n situatie verricht.

- Vertel de observator eerst welke handeling(en) U verricht en in welke volgorde. U hebt tien minuten de tijd voor dit station. 


\section{Algemeen:}

De slagaderlijke bloeding wordt in deze volgorde behandeld:

eerst wordt de art. brachialis dichtgedrukt

$27 \quad 0 \quad 0 \quad 0$

vervolgens wordt een wonddrukverband aangelegd

28000

2. Techniek:

De student plaatst:

de duim aan de mediale zijde van de bovenarm tussen de $\mathrm{m}$. biceps en de m.triceps

en de vingers aan de laterale zijde van de bovenarm

De student drukt de art.brachialis volledig dicht (crit.: in de art. radialis is geen pulsatie waarneembaar; te controleren door obs.) (4x)

De student geeft één van de volgende mogelijkheden aan om de art. brachialis dicht te drukken tijdens het aanleggen van het wonddrukverband

- door de patiënt

- door een omstander

$\begin{array}{llll}32 & 0 & 0 & 0\end{array}$

De wond wordt:

- met steriel gaas

33000

- volledig bedekt

Op het gaas wordt:

- op de plaats van de wond

- in de vorm van een prop

36000

- witte watten gelegd

$37 \quad 0 \quad 0 \quad 0$

Op de witte watten wordt vervolgens

- in de vorm van een prop

- vette watten of een klein voorwerp gelegd

Om druk uit te oefenen en de verbandmiddelen te fixeren wordt:

- een cambriczwachtel gebruikt

- die $6 \mathrm{~cm}$. breed is

41000


Goed Fout Niet

De zwachtel wordt zo om de pols gedraaid dat:

de circulaire winding het gaas en de watten volledig bedekken

$\begin{array}{llll}42 & 0 & 0 & 0\end{array}$

het gaas en de watten niet verschuiven

$\begin{array}{llll}43 & 0 & 0 & 0\end{array}$

het gedeelte van het steriele gaas dat op de

wond ligt wordt niet gecontamineerd $(2 \mathrm{x}$ )

$\begin{array}{llll}44 & 0 & 0 & 0\end{array}$

het wonddrukverband geeft voldoende druk op de arteria radialis om de bloeding te stelpen

$\begin{array}{llll}45 & 0 & 0 & 0\end{array}$

op de plaats van de wond worden de prop vette watten e.d. naar binnen gedrukt

$\begin{array}{llll}46 & 0 & 0 & 0\end{array}$

op de plaats van de wond kan het verband amper met een vinger worden ingedrukt( $2 x)$

$\begin{array}{llll}47 & 0 & 0 & 0\end{array}$

een vinger kan niet tussen het verband en de huid worden geschoven

$\begin{array}{llll}48 & 0 & 0 & 0\end{array}$

Eventuele opmerkingen van de observator voor de student: 
BIJLAGE 4 


\section{Voorbeeld criterialijst zesde studiejaar}

Criterialijst:

Domein:

Naam station:

Prod. datum:

Gemaakt door:

Bestemd voor:

Datum toets:

Duur station:

Benodigd:

\section{1}

Chirurgie/ Abdomen

Bloed bij de ontlasting, variant VI-1-1.

Werkgroep Abdomen J. Havas

6e jaars ' $93 /$ ' 94

7 oktober 1993

30 minuten

mannelijke simulatie patiënt, \pm 60 jaar

onderzoeksbank, stethoscoop, centimeter

Instructies voor de student(e):

Dit station duurt in zijn geheel 30 minuten.

Beschouw deze patiënt zoveel mogelijk als een echte patiënt. Het consult speelt zich af in een huisartspraktijk, waar u als co-assistent werkt (P.M.O.H.: practisch medisch onderwijs huisartsgeneeskunde).

Ga van de situatie uit dat u deze (simulatie)patiënt voor het eerst ziet.

Voer een geheel consult met de (simulatie)patiënt, $t / m$ de diagnose.

Bespreek datgene van het plan met de patiënt wat u verder relevant lijkt.

In dit station worden geen Communicatie Vaardigheden gevraagd.

Vertel tijdens het onderzoek steeds:

$$
\begin{aligned}
& \text { - wat U doet; } \\
& \text { - waar U op let en } \\
& \text { - wat Uw bevindingen zijn. }
\end{aligned}
$$

De laatste 10 minuten van dit station zijn bedoeld voor het nabespreken van het consult met de observatoren. Mocht u na 20 minuten echter niet klaar zijn met het consult, dan kunt u dit voortzetten ten koste van de nabespreektijd.

Als u deze instructie begrepen heeft, kunt u de patiënt binnen roepen.

Veel succes! 


\section{Observatorgegevens:}

\section{Algemene opmerkingen:}

Dit gedeelte bevat een uitgebreide hoeveelheid aan gegevens. $U$ moet deze observatorinstructie zien als een handvat en niet als iets wat u precies uit uw hoofd moet kennen. Wel aan te raden is om ruim vóór de aanvang van de toets de casus en de observatorinstructie goed door te lezen!

U dient als observator bij de simulatiepatiënt voorafgaand aan de toets zelf het buikonderzoek uit te voeren, zodat $u$ zich op de hoogte kunt stellen van hetgeen de student(e) zou moeten bemerken bij inspectie, auscultatie, percussie en palpatie van de buik.

Indien de student(e) nog ander lichamelijk onderzoek, dan het buikonderzoek, wil gaan doen (zoals pols, tensie, temperatuur, gewicht, thoraxonderzoek) geef dan aan dat dit niet uitgevoerd hoeft te worden en dat er geen afwijkende bevindingen hierbij zijn.

\section{Ad item met ponskode 27:}

Probeert u zich een oordeel te vormen of de student(e) een juiste en volledige speciële anamnese afneemt aan de hand van de gegevens vermeld bij de rol van de simulatiepatient onder het gedeelte "bij navraag, 1. speciële anamnese, blz 6". Er wordt van de student(e) minimaal verwacht dat er een aantal vragen binnen de tractus digestivus (voornamelijk over de ontlasting, opgezet gevoel in de buik, misselijkheid, eetlust en gewicht) gesteld worden.

Ad item met ponskode 28:

Probeert u zich een oordeel te vormen of de student(e) in de anamnese enkele aanvullende vragen stelt die aansluiten bij de gepresenteerde klacht van de patiënt. De gegevens van deze aanvullende vragen staan weer vermeld bij de rol van de simulatiepatiënt onder het gedeelte "bij navraag,

2. aanvullende vragen, blz.7".

Minimaal wordt verwacht dat de student(e) vraagt naar andere klachten, voorgeschiedenis (ziekten, operaties), intoxicaties (roken, alcohol en medicijngebruik), familieziektes en moeheid.

Ad item met ponskode 29:

Probeert u zich een oordeel te vormen of de student(e) een zinvolle en juiste algemene inspectie uitvoert.

Deze inspectie bevat onder anderen de volgende onderdelen: algemene indruk, kleur van sclerae (ogen), kleur van de huid, gezicht van de patiënt, houding van de patiënt, bestaat er bewegingsdrang?

De bevinding bij deze items die de student(e) moet vermelden, is de vermoeide indruk die de simulatie patiënt maakt.

Ad item met ponskode 30:

Probeert u zich een oordeel te vormen of de student(e) op een correcte wijze de inspectie van het abdomen uitvoert. In ieder geval moet de student(e) duidelijk de indruk maken dat hij/zij naar de buik kijkt (staand rechts van de patiënt, en eventueel vanuit nog andere richtingen, zoals vanuit hoofd-en voeteneinde van de patiënt). Belangrijk hierbij is dat de 
buik voldoende ontbloot (ontbloot bovenlichaam, patiënt in ondergoed; broek/jurk/rok los en iets naar beneden getrokken, in ieder geval beneden liesgebied, mag geaccepteerd worden) is en de patiënt in een juiste houding (in rugligging op de onderzoeksbank met de hoofdsteun in 30 graden stand en de armen losjes langs het onderlichaam) ligt.

\section{Ad item met ponskode 31:}

Probeert u zich een oordeel te vormen of de student(e) op een correcte wijze de auscultatie van het abdomen uitvoert. In ieder geval moet de student(e) met de stethoscoop (membraan) voldoende lang en op een aantal verschillende plaatsen (minimaal vier) in de buik luisteren om de peristaltiek te beoordelen. Daamaast moet de student(e) beoordelen of er eventuele vaatgeruisen te horen zijn over het verloop van een aantal buikarterieën (aorta abdominalis, bifurcatio aortae, aa.iliacae externae, aa.femorales, aa.renales).

Vraag aan de student(e) wat zijn/haar bevindingen zijn, indien hij/zij deze niet spontaan aan u meedeelt, met betrekking tot de peristaltiek en eventuele vaatgeruisen.

\section{Ad item met ponskode 32:}

Probeert $\mathrm{u}$ zich een oordeel te vormen of de student(e) op een correcte wijze de percussie van het abdomen uitvoert. Hierbij moet de student(e) in ieder geval op een aantal plaatsen (minimaal vier) de buik percuteren en daarbij beoordelen of er sprake is van een normale wisselende tympanie en geen percussiepijn. Daarnaast moet de student(e) ook de percussie van de lever en milt uitvoeren. Let hierbij op of de juiste techniek gehanteerd wordt en of de grenzen juist aangegeven worden.

Vraag aan de student(e) wat zijn/haar bevindingen zijn, indien hij/zij deze niet spontaan aan $\mathbf{u}$ meedeelt. Let algemeen ook op of de juiste percussietechniek gehanteerd wordt.

\section{Ad item met ponskode 33:}

Probeert $\mathrm{u}$ zich een oordeel te vormen of de student(e) op een correcte wijze de palpatie van het abdomen uitvoert. Hierbij moet de student(e) in ieder geval op een aantal plaatsen (minimaal vier) de buik palperen, waarbij hij/zij de oppervlakkige en diepe palpatie verricht. Bij de oppervlakkige palpatie moet de student(e) een indruk kunnen krijgen of de buik soepel of niet soepel (actief of passief spierverzet) is en bij de diepe palpatie of er sprake is van drukpijn en/of loslaatpijn. Daamaast moet de student(e) ook enkele organen in de buik palperen, waaronder het colon, de lever, de nieren en de milt. De student(e) onderzoekt of er slagpijn in de nierloges is.

Vraag weer aan de student(e) wat zijn/haar bevindingen zijn, indien hij/zij deze niet spontaan aan u meedeelt. Let algemeen op of de student(e) de techniek van het palperen (oppervlakkig, diep, organen) juist hanteert.

\section{Ad item met ponskode 35:}

De student(e) geeft aan het rectale toucher als onderdeel van het abdomen onderzoek te willen verrichten, maar verricht dit niet.

Al dan niet gevraagd geeft de observator de uitslag:

geen bijzonderheden, en geen bloed en/of slijm aan de gehandschoende vinger. 
Vraag van de observator: waar zou $U$ op letten, indien het rectaal toucher door $U$ wordt uitgevoerd?

Antwoord: Bij de inspectie letten op de anus en regio peri-analis en bij de palpatie op de sphincterspanning, rectumslijmvlies, prostaat (alle aspekten, zoals grootte/consistentie/vorm/oppervlak/drukpijnlijk?), vesiculae seminales (normaal niet palpabel) en de excavatio recto-vesicalis (normaal niet palpabel).

Ad item met ponskode 36:

De student(e) noemt én of meerdere mogelijkheden uit de differentiaaldiagnose.
Differentiaaldiagnose:
1. Rectum - of Coloncarcinoom
2. Colitis ulcerosa.
3. Morbus Crohn.
4. Diverticulosis.
5. Haemorrhoiden (interne).
6. Proctitis.
7. Solitair rectum ulcus.

Ad item met ponskode 37:

De student(e) benoemt de waarschijnlijkheidsdiagnose juist.

\section{Waarschijnlijkheidsdiagnose:}

Rectumcarcinoom (wat hoger, niet voor de toucherende vinger bereikbaar, gelegen), of coloncarcinoom.

Ad item met ponskode 38:

De student(e) geeft aan verdere diagnostiek te willen gaan doen. Indien de student(e) dit niet spontaan meedeelt of hen meteen wil doorverwijzen, vraag dan aan hem/haar welke diagnostiek hij/zij nog zou willen verrichten gezien de anamnese en het lichamelijke onderzoek.

\section{Diagnostiek:}

1. Algemeen oriënterend bloedonderzoek (BSE, $\mathrm{Hb}, \mathrm{Ht}$, leuco's; eventueel lever- en nierfuncties).

2. Sigmoïdoscopie met X-colon of coloscopie (Diagnostisch centrum).

Observator geeft diagnose aan student.

Rectum - of Coloncarcinoom

Ad item met ponskode 39:

Vraag van de observator: welk beleid zou U willen voeren?

Antwoord: Hij verwijst naar een chirurg. 


\section{Rol Simulatiepatiënt:}

$\mathrm{U}$ bent een 59 -jarige man.

Sinds ongeveer een maand heeft $u$ gemerkt dat $u$ wat bloed- en slijmverlies heeft bij de ontlasting, iets wat $\mathrm{u}$ nog niet eerder heeft gehad.

Indien de arts vraagt of er nog meer klachten zijn, kunt $u$ vermelden dat er bij het produceren van de ontlasting vaak wat pijn bestaat in en rond de anus, en dat u zich de laatste maanden wat meer moe voelt dan gebruikelijk.

Bij navraag geeft $U$ antwoord op de vragen over:

* De ontlasting:

- consistentie (vast of dun):

wisselend: soms dagen normale ontlasting, soms enkele dagen dunne of juist erg vaste ontlasting; voorheen altijd normaal;

- hoe vaak:

laatste 2 maanden 3-4 maal per dag; voorheen altijd 1-maal per dag;

- bloed en/of slijm:

zowel wat bloed als wat slijm bij de ontlasting; het bloed is niet iedere dag aanwezig, zit duidelijk op de ontlasting en is gering qua hoeveelheid (een spoortje bloed); het slijm is met het bloed vermengd;

- kleur:

normaal bruin (niet zwart, niet stopverf-achtig)

- pijn:

tijdens het produceren van ontlasting heeft u pijn in en rond de anus, met daarbij ook soms loze aandrang (aandrang zonder dat ontlasting komt); de pijn is wat stekend van karakter en is op zich goed uit te houden.

- vorm:

dunne, vaste sliertjes.

* Opgezet gevoel in de buik: Wel eens aanwezig, maar niet samenhangend met bepaalde factoren.

* Misselijk: Vooral de laatste week vaker een paar uur na de maaltijd last van.

* Eetlust: De laatste maanden wel wat verminderd.

* Gewicht: U heeft zelf het idee wel wat kilo's verloren te zijn (broeken zitten ruimer). Niet zelf met een weegschaal vastgesteld.

\section{Andere vragen:}

* De moeheid is geleidelijk een paar maanden geleden ontstaan; het idee dat het in de loop van de tijd wat toegenomen is; in de loop van de dag wordt het erger; vooral bij lichamelijke inspanning (bijv. fietsen naar het werk, werken in de tuin);

* Ziektes: Hoge bloeddruk; via de huisarts onder controle.

* Operaties: Noem de operaties die u gehad heeft.

* Ziektes in de familie: Uw vader van 83 jaar heeft suikerziekte (krijgt hiervoor een dieet en tabletten), verder is iedereen goed gezond. Geen darmziektes in de familie.

* Alcohol: Met mate; alleen op bijzondere gelegenheden (uit eten, feestje) een aantal pilsjes (2-5 glazen), en wel eens in het weekend voor het eten een borreltje (Jenever). 
* Roken: ongeveer pakje sigaretten per dag.

* Medicatie: $U$ heeft in verband met de hoge bloeddruk wat plastabletten (Hygroton, 1x per dag één tablet).

Op alle andere vragen van de arts kunt $u$ antwoorden daar geen last van te hebben, of dat er geen bijzonderheden over te vermelden zijn!

De te simuleren/spelen symptomen bij het lichamelijk onderzoek:

Algemeen moet $u$ proberen om wat mat en moe over te komen.

Verder hoeft u geen lichamelijke symptomen te simuleren. U kunt verwachten dat uw buik onderzocht zal worden. $U$ kunt verwachten dat hiervoor de gehele buik (vanaf de ondergrens van de ribbenboog tot aan de schaamstreek) en eventueel het bovenlichaam ontbloot dient te worden.

Als u de kamer binnengeroepen wordt kunt u normaal lopen. De student(e) moet duidelijk maken hoe u moet gaan liggen; indien hij of zij dat niet doet, moet u op de rug gaan liggen met de armen onder het hoofd.

Het RT wordt niet bij u verricht; de student(e) kan er naar vragen, waarna de observator de gegevens aan hem/haar meedeelt.

\section{Extra aanvullende informatie (alleen voor simulatiepatiènt):}

U gaat met deze klachten naar de huisarts, maar als u daar aankomt wordt aan u gevraagd of $u$ het goed vindt door een co-assistent (oudere jaars student geneeskunde die stage loopt) onderzocht te worden.

Ga van de situatie uit dat de student even deskundig is als de huisarts, en dat u instemt om door de student onderzocht te worden. 


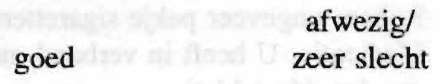

(1) (2) (3) (4) (5) (6)

\section{Anamnese}

De student(e)

(*) neemt de juiste speciële anamnese af

$\begin{array}{lllllll}27 & 0 & 0 & 0 & 0 & 0 & 0\end{array}$

(*) neemt juiste aanvullende anamnese af

$\begin{array}{lllllll}28 & 0 & 0 & 0 & 0 & 0 & 0\end{array}$

\section{Lichamelijk Onderzoek}

De student(e),

(*) verricht een juiste algemene inspectie

$\begin{array}{lllllll}29 & 0 & 0 & 0 & 0 & 0 & 0\end{array}$

verricht een juist en volledig abdomen onderzoek, dat wil zeggen:
(*) -inspectie
(*) -auscultatie
(*) -percussie
(*) -palpatie

$\begin{array}{lllllll}30 & 0 & 0 & 0 & 0 & 0 & 0\end{array}$

$\begin{array}{lllllll}31 & 0 & 0 & 0 & 0 & 0 & 0\end{array}$

$\begin{array}{lllllll}32 & 0 & 0 & 0 & 0 & 0 & 0\end{array}$

$\begin{array}{lllllll}33 & 0 & 0 & 0 & 0 & 0 & 0\end{array}$

verricht de onderdelen van het buikonderzoek ook in de juiste volgorde:

insp.- ausc.- perc.- palp.

340

0

(*) geeft aan het rectale toucher te willen verrichten; daarnaast vraag van observator

$\begin{array}{lllllll}35 & 0 & 0 & 0 & 0 & 0 & 0\end{array}$ 
goed

afwezig/

zeer slecht

\section{Differentiaaldiagnose}

De student(e)

(*) stelt de juiste differentiaal diagnose

Waarschijnlijkheidsdiagnose

De student(e),

(*) komt tot een juiste waarschijnlijkheidsdiagnose

Plan

De student(e)

(*) verricht zinvolle diagnostiek

$\left.{ }^{*}\right)$ voert het juiste beleid $\begin{array}{lllllll}36 & 0 & 0 & 0 & 0 & 0 & 0\end{array}$

370 0

Naam simulatiepatiënt:

Eventuele opmerkingen van de observator aan de student: 


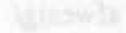

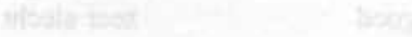

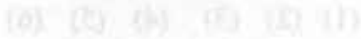




\section{BIJLAGE 5}


Evaluatie Vaardigheidstoets: Enquête Studenten

Project Evaluatie Studieresultaten

Vaardigheidstoets FdG 1992/1993

Dit formulier dient direct na de toets te worden ingevuld en ingeleverd

Toetsnummer:

Jaargroep:

$$
\begin{aligned}
& 1=\text { geheel oneens } \\
& 2=\text { oneens } \\
& 3=\text { neutraal }
\end{aligned}
$$

$\begin{array}{ll}\text { Naam student } & 2=\text { oneens } \\ 3 & =\text { neutraal }\end{array}$

Organisatie / Algemeen:

1. Het was mij van te voren duidelijk in welke vorm het circuit werd afgenomen

2. De organisatie verliep uitstekend

\section{Stations:}

3. De meeste vaardigheden die ik moest demonstreren

kolom te omcirkelen

$$
\begin{aligned}
4 & =\text { eens } \\
5 & =\text { geheel eens } \\
6= & \text { niet te beoordelen } \\
& \quad / \text { geen mening }
\end{aligned}
$$ vind ik relevant voor de basisarts
4. Ik had voldoende tijd om de meeste vaardigheden te demonstreren

5. De opdrachten waren voor mij duidelijk

$\begin{array}{lllllll}13 & 1 & 2 & 3 & 4 & 5 & 6 \\ 14 & 1 & 2 & 3 & 4 & 5 & 6\end{array}$

6. Ik vond het moeilijk om "hardop denkend" het onderzoek te verrichten, zowel bij fantomen als bij simulatiepatiënten

7. Ik vond het circuit representatief voor wat ik op het Skillslab heb geleerd

8. I.k vond het circuit representatief voor wat ik in de praktijk heb gezien

$\begin{array}{lllllll}15 & 1 & 2 & 3 & 4 & 5 & 6\end{array}$

$\begin{array}{lllllll}16 & 1 & 2 & 3 & 4 & 5 & 6\end{array}$

$\begin{array}{lllllll}17 & 1 & 2 & 3 & 4 & 5 & 6\end{array}$

(Co-) Observatoren:

9. De meeste observatoren probeerden mij gerust te stellen 


$$
\begin{aligned}
& 1=\text { geheel oneens } \\
& 2=\text { oneens } \\
& 3=\text { neutraal }
\end{aligned}
$$

$$
\begin{aligned}
& 4=\text { eens } \\
& 5=\text { geheel eens } \\
& 6=\text { niet te beoordelen/ geen mening }
\end{aligned}
$$

10. Het binnenkomen van de co-observatoren vond ik storend

kolom te omcirkelen

11. Ik vond het goed dat er co-observatoren waren

12. Ik vond het prettig om feed-back te krijgen van de observatoren

$\begin{array}{lllllll}19 & 1 & 2 & 3 & 4 & 5 & 6\end{array}$

$\begin{array}{lllllll}20 & 1 & 2 & 3 & 4 & 5 & 6\end{array}$

$\begin{array}{lllllll}21 & 1 & 2 & 3 & 4 & 5 & 6\end{array}$

Simulatiepatiënten:

13. Tk vind de simulatiepatiënten goed getraind

14. $\mathrm{lk}$ heb het circuit beter afgelegd dan ik op grond van mijn trainingen / praktijkkontakten verwachtte

15. De vaardigheidstoets vond ik moeilijk

$\begin{array}{lllllll}22 & 1 & 2 & 3 & 4 & 5 & 6\end{array}$

$\begin{array}{lllllll}23 & 1 & 2 & 3 & 4 & 5 & 6\end{array}$

$\begin{array}{lllllll}24 & 1 & 2 & 3 & 4 & 5 & 6\end{array}$

Aanvullende opmerkingen, punten van kritiek, suggesties voor de toekomst:

Ten aanzien van de organisatie:

Ten aanzien van de voorbereiding / trainingen:

Ten aanzien van de stations / criterialijsten:

Overige / algemene opmerkingen: 

BIJLAGE 6 


\section{Evaluatie Vaardigheidstoets: Enquete Observatoren}

Project Evaluatie Studieresultaten

Vaardigheidstoets FdG 1992/1993

Dit formulier s.v.p. na

Toetsnummer :

afloop van de toets

Jaargroep:

Obs.Nummer:

invullen en inleveren

Domeinnummer:

Naam observator:

Nummer observator:

Station(s) waarbij u observator was:

Hoe vaak was u reeds eerder observator bij vaardigheidstoetsen (in het verleden en vandaag):

é́nmaal

$2 \mathrm{t} / \mathrm{m} 4$ maal meer dan 4 mal

Hoe vaak was u reeds observator bij dit station (in het verleden en vandaag):

énmaal $\quad 2 \mathrm{Vm} 4$ maal meer dan 4 maal

Betekenis van de cijfers:

1 = geheel oneens

$$
\begin{aligned}
& 4=\text { eens } \\
& 5=\text { geheel eens } \\
& 6=\text { niet te beoordelen/geen mening }
\end{aligned}
$$

$2=$ oneens

$3=$ neutraal

Algemeen:

kolom te omcirkelen

1. Over het algemeen genomen ben ik tevreden

met de gang van zaken rond deze

vaardigheidstoets

$\begin{array}{lllllll}20 & 1 & 2 & 3 & 4 & 5 & 6\end{array}$

2. Ik vind de vaardigheidstoets een geschikte methode om het vaardigheidsniveau van studenten te evalueren.

$\begin{array}{lllllll}21 & 1 & 2 & 3 & 4 & 5 & 6\end{array}$

Organisatie/Uitvoering:

3. De algehele organisatie verliep naar mijn mening uitstekend.

4. Ik had de grootste moeite mij te $\begin{array}{lllllll}22 & 1 & 2 & 3 & 4 & 5 & 6\end{array}$ oriënteren in de klaarliggende observatieformulieren.

5. Ik had onvoldoende tijd om de observatieformulieren in te vullen.

\section{Voorbereiding/Training:}

6. Ik heb deelgenomen aan de training lvoorbespreking. 
Betekenis van de cijfers:

$1=$ geheel oneens

$$
\begin{aligned}
& 4=\text { eens } \\
& 5=\text { geheel eens } \\
& 6=\text { niet te beoordelen'geen mening }
\end{aligned}
$$

$2=$ oneens

$3=$ neutraal

kolom te omcirkelen

7. Het was mij in alle opzichten duidelijk wat er van mij als observator werd verwacht.

8. De observatortraining vormde een goede $\begin{array}{lllllll}26 & 1 & 2 & 3 & 4 & 5 & 6\end{array}$ voorbereiding op mijn rol als observator.

$\begin{array}{lllllll}27 & 1 & 2 & 3 & 4 & 5 & 6\end{array}$

Stations/Criterialijsten:

9. Ik vind de vaardigheden die de studenten in mijn station moesten demonstreren overbodig.

10. Ik had moeite met het invullen van de checklist.

$\begin{array}{lllllll}29 & 1 & 2 & 3 & 4 & 5 & 6\end{array}$

11. Ik vind de checklist zeer bruikbaar.

$\begin{array}{lllllll}30 & 1 & 2 & 3 & 4 & 5 & 6\end{array}$

Aanvullende opmerkingen, punten van kritiek, suggesties voor de toekomst: Ten aanzien van de organisatie:

Ten aanzien van de voorbereiding / trainingen:

Ten aanzien van de stations / criterialijsten:

Overige / algemene opmerkingen: 


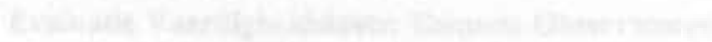

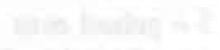

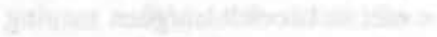

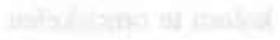

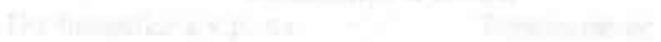

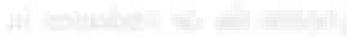




\section{CURRICULUM VITAE}

Scheltus Jan van Luijk werd geboren op 5 april 1950 in Enschede. De HBS-B opleiding werd voltooid in 1969 aan het Stedelijk Lyceum in Enschede. In datzelfde jaar werd begonnen met de studie geneeskunde in Groningen. Deze studie werd in 1978 afgesloten. In zijn studietijd heeft hij ook twee jaar sociologie gestudeerd en was gedurende twee jaar student-assistent op het Instituut voor Sociaal Medische Wetenschap. In 1978 werd hij als universitair docent verbonden aan het Skillslab van de Rijksuniversiteit Limburg. Hierbij werd "vaardigheidstoetsing" het speciale aandachtsveld. Sedert 1991 is hij verbonden aan de vakgroep Onderwijsontwikkeling en Onderwijsresearch. Als lid van het Project Evaluatie Studieresultaten is vaardigheidstoetsing het voornaamste aandachtsveld gebleven. 


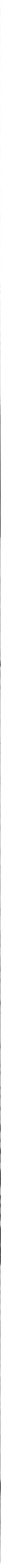

